UNIVERSIDADE DE SÃO PAULO

Faculdade de Arquitetura e Urbanismo

\title{
PARQUE NATURAL DO PEDROSO: UMA UNIDADE DE CONSERVAÇÃO EM ÁREA URBANA
}

\author{
Ana Paula de Freitas
}

Dissertação de Mestrado apresentada à Faculdade de Arquitetura e Urbanismo da Universidade de São Paulo para concorrer ao título de mestre em: Arquitetura e Urbanismo - Área de concentração: Paisagem e Ambiente.

Orientadora: Profa. Dra. Catharina Pinheiro C. dos Santos Lima

\section{SÃO PAULO}

2011

EXEMPLAR REVISADO E ALTERADO EM RELAĈ̃O À VERSÃO ORIGINAL, SOB RESPONSABILIDADE DO AUTOR E ANUÊNCIA DO ORIENTADOR

O original se encontra disponível na sede do programa São Paulo, 06 de julho de 2011 
Para Robson e Caio 


\section{AGRADECIMENTOS}

Agradeço à querida orientadora Catharina pelo acolhimento, confiança e pelas diretrizes fundamentais para que este trabalho pudesse tomar a direção e o formato que aqui está.

Aos professores das disciplinas e da qualificação, pela contribuição teórica e metodológica.

Agradeço a todos que, direta ou indiretamente, contribuíram para a realização deste trabalho. Aos colegas da GEPLAN, que me acompanharam nesse período com palavras de incentivo, especialmente ao Leonardo, ao Márcio e à Flávia, pela compreensão.

Ao Diretor Jarbas pela cessão das informações técnicas e iconográficas, fundamentais para o desenvolvimento deste trabalho. Ao Aldo e Celso pelas contribuições, e à Tatiana e Elaine pela amizade e incentivo.

Agradeço à GEMA pelo apoio à realização do biomapa, em especial à Ana por me apresentar os caminhos para a pesquisa qualitativa, que tanto contribuiu para enriquecer a dissertação e, da mesma forma, à Suzana pelas indicações sobre história oral e pelas observações.

Ao Centro de Referência do SEMASA e ao Museu de Santo André, à Ruth pelas contribuições e à Márcia e Melina pela solicitude.

Em especial, agradeço aos meus pais e ao querido Robson pela paciência e apoio, sem os quais não seria possível a realização deste trabalho. 


\section{RESUMO}

Este trabalho é uma análise sobre uma unidade de conservação de proteção integral - o Parque Natural Municipal do Pedroso, em Santo André dentro de um contexto urbano.

A paisagem do Pedroso é fruto de uma herança de processos econômicos e sociais, que atuaram na formação do território, configurando-o como um remanescente fundiário e um fragmento de Mata Atlântica. Parte da problemática atual advém dessa herança de apropriações, de exploração dos recursos da natureza e do contato com a área urbana que avançou sobre seus limites, e que atualmente representa uma pressão antrópica sobre essa área natural, envolvendo outros municípios além de Santo André.

Da necessidade de garantir a integridade de um manancial de abastecimento da cidade é que surge o parque, inicialmente como uma reserva florestal, passando por um período como parque urbano com atividades voltadas para o lazer, e no final da década de 1990, sendo elevado a categoria de unidade de conservação, dentro de um arcabouço legal que visa proteger ecossistemas naturais e oferecer maior garantia a sua conservação.

O que se discute a partir daí, são as contradições que essa legislação apresenta diante de um contexto urbano como o do Pedroso, tendo sido importada de uma realidade distinta da brasileira, a partir de um ideário que privilegia a conservação da natureza e não o homem integrado a ela. $O$ enfoque da paisagem expõe a complexidade e a pluralidade de compreensões acerca do tema. 


\begin{abstract}
This dissertation refers to an analysis about a Conservation Unit with environmental severe restrictions - the Pedroso Municipal Natural Park, within an urban area in the city of Santo André, state of São Paulo.

Pedroso's landscape is the legacy of social and economic processes that produced the territory configuration, thus consolidating it as a land property remnant and as an Atlantic Forest fragment. Part of the current problems is due to the inheritance of those processes for appropriation and exploitation of natural resources together with the sprawl of the urban areas towards its boundaries, which represents a pressure over this natural area, reaching other municipalities beyond Santo André.

The Park emerges from the demand of protecting the city's watershed, firstly as a forest reserve, then as an urban park with recreation activities and finally , in the 1990's, it was raised to the category of a Conservation Unit, supported by legislation aiming the natural ecosystem preservation and offering more guarantees to its conservation.

This work then reflects about the contradictions represented by this legislation when confronted with the urban context over Pedroso, having also been imported from a foreign reality, distinct from the Brazilian one, and which is based on the restricted conservation of nature, without the integration of man. This work focuses on the park as a broader concept of landscape revealing both the complexity and the diversity of approaches on the subject.
\end{abstract}




\section{LISTA DAS FOTOS}

Foto 1 - Olaria - Parque do Pedroso. Fonte: Departamento de Gestão

Ambiental, SEMASA, 2003.

Foto 2 - Antiga saída do pedalinho. Fonte: Acervo Museu de Santo André,

Dr. Octaviano Armando Gaiarsa.

Foto 3 - Lago com pedalinho. Fonte: Maria e Miguel Pastor.[198-].

Foto 4 - Capela de Santa Cruz. Fonte: Departamento de Gestão Ambiental,

SEMASA, 2006.

Foto 5 - Estação B ou segunda torre do teleférico, ao fundo o lago e as

quadras de esportes. Fonte: Departamento de Gestão Ambiental, SEMASA, 2006.

Foto 6 - Marquise do teleférico e lago ao fundo. Fonte: Coordenadoria de

Comunicação Social, SEMASA, 2008.

Foto 7 - Folder. Fonte: PSA. Acervo Museu de Santo André, Dr. Octaviano

Armando Gaiarsa, s.d.

Foto 8 - Usuários do parque na ponte. Fonte: Maria e Miguel Pastor.[198-].

Foto 9 - Música ao vivo. Ao lado da marquise do teleférico. Fonte: Maria e Miguel Pastor, [198-].

Foto 10 - Antiga ponte de madeira. Fonte: Acervo Museu de Santo André, Dr. Octaviano Armando Gaiarsa, junho 1990.

Foto 11 - Nova ponte de estrutura metálica e piso de madeira, no mesmo local da antiga. Fonte: DGA/SEMASA, 2009.

Foto 12 - Parquinho. Fonte: Maria e Miguel Pastor, [198-].

Foto 13 - Novo parque infantil implantado parcialmente. Fonte:

Departamento de Gestão Ambiental, SEMASA, 2009.

Foto 14 - Área de quiosques e churrasqueiras. Fonte: Departamento de

Gestão Ambiental, SEMASA, 2005.

Foto 15 - Área de quiosques e churrasqueiras. Fonte: Departamento de

Gestão Ambiental, SEMASA, 2009. 
Foto 16 - Inauguração do Santuário Nacional de Umbanda, no final da

década de 1970. Fonte: Acervo Museu de Santo André, Dr. Octaviano

Armando Gaiarsa, dec. 70.

Foto 17 - Santuário Nacional de Umbanda. Imagens e cachoeira ao fundo.

Fonte: Relatório da Federação Umbandista do Grande ABC, 2005.

Foto 18 - Obras do trecho em ponte sobre a Represa Billings. Núcleo

Pintassilgo à direita. Fonte: DGA/SEMASA, 2009.

Foto 19 - Rodoanel implantado próximo ao bairro Recreio da Borda do

Campo. Trecho anterior ao da foto 18. Fonte: Ana Paula de Freitas, 2010.

Foto 20 - Parque do Pedroso. Área não identificada. Fonte: Maria e Miguel

Pastor [198-].

Foto 21 - Morro cortado na Pedreira Montanhão. Processo de regeneração da vegetação. Fonte: FUGABC, 2005.

Foto 22 - Vista geral do Jardim. Tori e local das placas comemorativas à direita (ao fundo). Fonte: Coordenadoria de Comunicação Social, SEMASA, 2008.

Foto 23 - Ponte e vista para a via (esquerda) que leva ao local da antiga Olaria. Fonte: Departamento de Gestão Ambiental, SEMASA, 2005.

Foto 24 - Estrada do Pedroso. Limite com área urbana (Norte). Fonte:

Departamento de Gestão Ambiental, SEMASA, 2005.

Foto 25 - Divisa com o Núcleo Toledana. Fonte: Departamento de Gestão Ambiental, SEMASA, 2006.

Foto 26 - Local da antiga Olaria. Fonte: Departamento de Gestão Ambiental, SEMASA, 2005.

Foto 27 - Núcleo Pintassilgo, antigo Kart, grupamento ecológico e Marquise.

Fonte: Departamento de Gestão Ambiental, SEMASA, 2005.

Foto 28 - Antigo Haras. Estrada do Montanhão, $\mathrm{n}^{\circ}$ 115. Fonte: Departamento de Gestão Ambiental, SEMASA, 2008.

Foto 29 - Implantação do Rodoanel e Núcleo Pintassilgo. Fonte:

Departamento de Gestão Ambiental, SEMASA, 2008.

Foto 30 - Oficina de biomapa com moradores do entorno do Parque do

Pedroso. Fonte: Departamento de Gestão Ambiental, SEMASA, 2010.

Foto 31 - Oficina de biomapa com moradores do entorno do Parque do

Pedroso. Fonte: Departamento de Gestão Ambiental, SEMASA, 2010. 


\section{LISTA DAS FIGURAS}

Figura 1 - Crescimento urbano de Santo André. Fonte: DISE/SOPP/PSA. 16

Figura 2 - Localização de Santo André na Região Metropolitana de São

Paulo. Fonte: EMPLASA, 2003, e PSA, 2009.

Figura 3 - Macrozonas de Santo André de acordo com o Plano Diretor (lei

8.696, de 17 de Dezembro de 2004). Fonte: Secretaria de Desenvolvimento Urbano e Habitação. PSA, 2004

Figura 4 - Uso do solo no entorno do Parque do Pedroso.

Fonte: EMPLASA, 2010, e PSA, 2009.

Figura 5 - Folder informativo. Fonte: SEMASA e PSA, 2005.

Figura 6 - Variações no traçado do Rodoanel Metropolitano no Parque do

Pedroso, trecho Sul - Santo André. Fonte: Departamento de Gestão

Ambiental, SEMASA, s.d.

Figura 7 - Levantamento aerofotogramétrico de 1962. Fonte: Acervo Museu de Santo André, Dr. Octaviano Armando Gaiarsa.

Figura 8 - Levantamento aerofotogramétrico de 1972. Fonte: Base aerofotogrametria e projetos $\mathrm{S}$. A.

Figura 9 - Levantamento aerofotogramétrico de 1990. Fonte: ADECO/SDUH/PSA.

Figura 10 - Levantamento aerofotogramétrico de 2008. Fonte: "Google Earth".

Figura 11 - Atlas dos remanescentes florestais da Mata Atlântica, Estado de 66 São Paulo. Fonte: SOS Mata Atlântica e INPE, 2010.

Figura 12 - Perfil do Maciço do Bonilha Fonte: COMDEPHAAPASA, processo $4272598 / 8$.

Figura 13 - Unidades de Conservação na Região Metropolitana de São 


\section{LISTA DOS GRÁFICOS}

Gráfico 1 - Crescimento populacional das cidades do Grande ABC.

Fonte: DISE/SOPP/PSA e CENSO 2010 - IBGE.

Gráfico 2 - Distribuição das Unidades de Conservação Municipais na

Região Metropolitana de São Paulo. Fonte: SEADE, 2003 e GONÇALVES e MORENO, 2009.

\section{LISTA DAS TABELAS}

Tabela 1 - Características dos bairros do entorno do Parque do Pedroso. Fonte: IBGE/SEADE/DISE/SOPP/PSA e SEMASA.

Tabela 2 - Assentamentos precários do entorno do Parque do Pedroso limites norte e sul. Plano Municipal de Habitação, PSA, 2006. SEMASA.

Tabela 3 - Mananciais responsáveis pelo abastecimento de água em

Santo André. Fonte: SEMASA, 2008.

Tabela 4 - Ocupações. Número de domicílios dentro dos limites do

Parque do Pedroso. Fonte: GCA/ SEMASA, 2008.

Tabela 5 - Desmatamento da Mata Atlântica. Fonte: Brasil, 2010.

Tabela 6 - Número de áreas protegidas criadas por década no mundo e no Brasil. Fonte: Diegues, 2001.

Tabela 7 - Unidades de Conservação Municipais da Região Metropolitana de São Paulo. Fonte: SEADE/EMPLASA, 2003; GONÇALVES \& MORENO, 2009 e SANTO ANDRÉ, 2009. 


\section{CRÉDITO DO MODELO DE CARTA DE CESSÃO}

Museu de Santo André Doutor Octaviano Armando Gaiarsa - adaptado a

FAUUSP por Ana Paula de Freitas. 


\title{
LISTA DE SIGLAS
}

\begin{abstract}
APA - Área de Proteção Ambiental
APP - Área de Preservação Permanente

APRM-B - Área de Preservação e Recuperação de Mananciais - Billings

APRM-G- Área de Preservação e Recuperação de Mananciais - Guarapiranga

CCS - Coordenadoria de Comunicação Social

CDHU - Companhia de Desenvolvimento Habitacional e Urbano do Estado de São Paulo.

COMDEPHAAPASA - Conselho Municipal de Defesa do Patrimônio Histórico, Artístico, Arquitetônico-Urbanístico e Paisagístico da Prefeitura de Santo André CONDEPHAAT - Conselho de Defesa do Patrimônio Histórico, Arqueológico, Artístico e Turístico do Estado-vinculado à Secretaria de Estado da Cultura e criado em 1969.
\end{abstract}

CONAMA - Conselho Nacional de Meio Ambiente

CTEEP - Companhia de Transmissão de Energia Elétrica Paulista.

CVU - Corredores verdes urbanos

DERSA - Desenvolvimento Rodoviário S/A

DGA - Departamento de Gestão Ambiental

DPO - Departamento de Projetos e Obras

EGPP - Encarregatura de Gestão do Parque do Pedroso

EIA / RIMA - Estudo de Impacto Ambiental / Relatório de Impacto Ambiental

FBCN - Fundação Brasileira para a Conservação da Natureza criada em 1958

FCMSB - Fundo Câmara Municipal de São Bernardo

FUGABC- Federação Umbandista do Grande ABC

GCA- Gerência de Controle Ambiental

GEMA - Gerência de Educação e Mobilização Ambiental

GEPAM - Gerenciamento Participativo em Área de Mananciais

IBAMA - Instituto Brasileiro do Meio Ambiente e dos Recursos Naturais

Renováveis

IBDF - Instituto Brasileiro de Desenvolvimento Florestal

IBGE - Instituto Brasileiro de Geografia e Estatística

MSAOAG - Museu de Santo André Doutor Octaviano Armando Gaiarsa

ONU - Organização das Nações Unidas 
PSA - Prefeitura Municipal de Santo André

PDPA- Planos de Desenvolvimento e Proteção Ambiental

RMSP - Região Metropolitana de São Paulo

SABESP - Campanhia de Saneamento Básico do Estado de São Paulo

SEMASA - Serviço Municipal de Saneamento Ambiental de Santo André

SNUC - Sistema Nacional de Unidades de Conservação

TAC - Termo de Ajustamento de Conduta

UICN - União Internacional para a Conservação da Natureza e dos Recursos

Naturais.

UGRHI - Unidade de Gerenciamento de Recursos Hídricos 


\section{INDÍCE}

Introdução

\section{Capítulo I}

Aspectos históricos da formação de Santo André e região.

A região

A produção rural da região $\quad 9$

A expansão urbana 13

Divisão territorial 21

As águas e o Parque $\quad 25$

O Parque do Pedroso, nascido das águas 31

Parque Regional e Jardim Botânico do Pedroso 33

\section{Capítulo II}

Fragmentos Florestais

Antecedentes 49

A exploração da mata em Santo André $\quad 50$

Caracterização ambiental $\quad 58$

Vegetação 58

$\begin{array}{ll}\text { Fauna } & 61\end{array}$

Relevo $\quad 63$

Clima $\quad 64$

O processo de fragmentação $\quad 65$

$\begin{array}{ll}\text { Tamanho } & 67\end{array}$

Isolamento $\quad 67$

O entorno dos fragmentos 68

A forma e o efeito borda 68

Metapopulação $\quad 69$

A história da fragmentação $\quad 69$

$\begin{array}{ll}\text { Conectividade } & 70\end{array}$

$\begin{array}{ll}\text { Ecologia de paisagens } & 72\end{array}$

\section{Capítulo III}

A paisagem e a unidade de conservação

$\begin{array}{ll}\text { Paisagem } & 74\end{array}$

A proteção de áreas naturais. A abordagem cultural 78

O Patrimônio dentro da unidade de conservação $\quad 81$

A proteção de áreas naturais. Abordagem ambiental 84

Os parques nacionais no Brasil $\quad 87$

O Parque Natural do Pedroso. Uma unidade de conservação de proteção 95

integral em área urbana

A população urbana e a unidade de conservação 99

$\begin{array}{ll}\text { As várias visões sobre o Parque do Pedroso } & 104\end{array}$

Pesquisa qualitativa individual - Depoimentos orais 113

$\begin{array}{lr}\text { Pesquisa coletiva - Biomapa } & 115\end{array}$

$\begin{array}{lr}\text { Considerações Finais } & 119\end{array}$ 
Bibliografia

Anexo I

Entrevistas

Anexo II

Carta de Cessão

204 


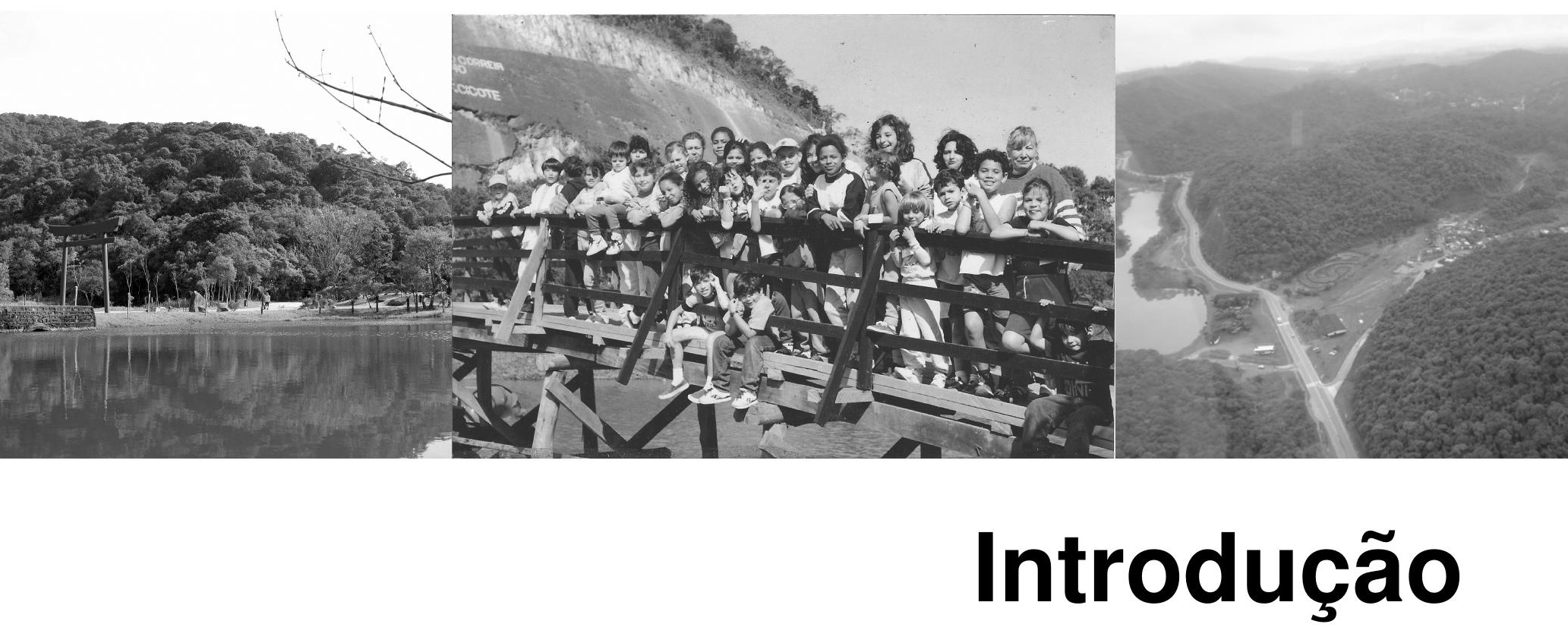


A tensão entre os processos biofísicos e humanos em ambientes urbanos têm demandado esforços de técnicos, gestores públicos e pesquisadores no sentido da busca de respostas e modelos de organização espacial capazes de fazer frente à complexidade das relações envolvidas, acomodando as funções sociais em bases naturais, por vezes de grande sensibilidade.

$\mathrm{Na}$ cidade de Santo André, Região Metropolitana de São Paulo, a singularidade de seu suporte biofísico torna essa questão ainda mais difícil de elucidar, se considerarmos que $58,10 \%$ de sua zona urbana encontra-se no que a legislação ambiental configura como "área de mananciais", concentrando 4,57\% da população do município, sendo que a maior parte, cerca de $3,59 \%{ }^{1}$, está situada entre o braço do Rio Grande e o Parque Natural Municipal do Pedroso, no limite das Macrozonas Urbana e de Proteção Ambiental (mananciais)².

O adensamento nessa região intensificou-se na década de 1970, desencadeado por um processo de pauperização da população, aliado à valorização das áreas mais centrais, levando a ocupação das áreas mais periféricas, ambientalmente sensíveis, pela população de baixa renda.

O Parque do Pedroso reúne tanto funções ambientais, quanto urbanas. Considerado um remanescente de Mata Atlântica, funciona como um filtro climático local e regional, barrando a poluição atmosférica e cumprindo a função de uma zona tampão, um grande amortecimento, para região de proteção aos mananciais do município. Acomoda funções urbanas como fonte abastecedora de água potável com aproximadamente $6 \%$ do total da água consumida no município de Santo André; com a Estrada do Pedroso seccionando o parque e estabelecendo a ligação entre a Macrozona Urbana e os Bairros Parque Miami, Jardim Riviera e Recreio da Borda do Campo e, de seu histórico de usos e ocupações, herdou a vocação para o lazer, que atualmente representa uma demanda significativa de um entorno populoso e carente de opções.

O Parque situa-se entre duas polaridades: uma legislação ambiental rigorosa e uma realidade urbana complexa. A legislação atua privilegiando a conservação da natureza, sem o homem integrado a ela, e considera que a população urbana e seus interesses econômicos contrariam a ideia de proteção das áreas naturais. 
Diante desse panorama traçado é que este trabalho se insere, objetivando compreender as contradições entre a legislação aplicada ao parque e sua realidade, procurando mostrar que a intensa atividade humana que atuou sobre essa área deixou como herança particularidades tanto biofísicas, quanto culturais e que é a somatória dessas duas dimensões que devem ser consideradas. O trabalho reflete ainda sobre as limitações da legislação na garantia da conservação do parque e aposta no planejamento, no projeto e na gestão, compartilhados entre técnicos, gestores e sociedade civil, como um caminho para superação de impasses de grande complexidade.

Esta dissertação divide-se em três capítulos, um histórico, outro sobre o processo de fragmentação e um último que apresenta a origem da proteção de áreas naturais no Brasil e o caso do Parque do Pedroso.

Buscou-se a bibliografia para montagem dos textos, em livros, artigos de jornais, revistas periódicas do município, relatórios, fontes documentais (processos), e na base jurídica Municipal, Estadual e Federal. Foram utilizadas ilustrações baseadas em fotos aéreas do Município de Santo André das décadas de 1962, 1972, 1990 e 2008, mostrando a evolução da ocupação do Parque, as áreas desmatadas e o levantamento iconográfico, com fotos antigas e atuais.

Através da noção de paisagem utilizada nesta dissertação como um enfoque, uma categoria de análise, que sintetiza a idéia da natureza como uma interação entre o natural e o social, entende-se a paisagem do Pedroso como o resultado da formação territorial, fruto de uma apropriação econômica e social. A história traçada no primeiro capítulo ofereceu subsídios para compreender a problemática do contexto atual, em uma situação urbana conflitante com a ideia da conservação da natureza.

Surgido de uma alternativa para captação de água de abastecimento do município em meados da década de 1940, o parque atual passaria por várias fases, inicialmente como Reserva Florestal, depois como Parque Regional e Jardim Botânico do Pedroso, um parque urbano, com várias atividades recreativas até sua instituição como uma unidade de conservação de proteção integral, na categoria de Parque Natural Municipal, no final da década de 1990, objetivando oferecer

\footnotetext{
${ }^{1}$ IBGE, Censo 2000 (Santo André, 2008a).

${ }^{2}$ Ordenamento territorial do Município de Santo André, definido no Plano Diretor, Lei nº 8.696/ 2004.
} 
garantias adequadas de proteção ao ecossistema, diante da forte pressão do avanço urbano, que alterou significativamente seu entorno.

O segundo capítulo procurou expor de forma sucinta as decorrências de um processo de fragmentação, apresentando os fatores que podem influenciar o futuro da biodiversidade do Parque do Pedroso. Esse tema surgiu a partir da condição desse remanescente de Mata Atlântica, cujo processo de fragmentação iniciou-se no passado com a exploração dos recursos naturais e com as apropriações por chácaras, olarias, carvoarias e moradias, passando por queimadas, desmatamentos, pela introdução de espécies exóticas etc., culminando em uma intervenção recente e drástica: a implantação do Rodoanel Metropolitano, causando um rompimento da conecção de fluxo gênico, com outros fragmentos na região mais florestada do município.

O terceiro e último capítulo trouxe uma discussão em torno da constituição de unidades de conservação no Brasil sobre as bases motivadoras para a proteção da natureza a partir da necessidade da conservação dessas áreas naturais diante das alterações ambientais intensificadas no período urbano-industrial.

O modelo de criação de parques nacionais norte-americanos, baseado em uma idealização da natureza onde o homem seria apenas um visitante, foi importado para o Brasil e para outros países da América Latina com realidades bem distintas desse país de origem.

Através da reflexão sobre a paisagem que se incorporam nas discussões acerca da proteção de áreas naturais, as questões culturais, as interações entre homem e natureza.

A utilização de entrevistas e de uma oficina de biomapa, neste trabalho, surgiu da necessidade de se completar o "quadro" sobre essa área natural com o componente humano. Foram realizadas entrevistas individuais - documentos orais segundo a classificação de Lang (1996) - e um biomapa como técnica para um exercício coletivo com um grupo pequeno de pessoas dos bairros do entorno do Parque do Pedroso.

A metodologia das entrevistas baseou-se em:

1. Numa seleção de pessoas representativas já conhecidas. A escolha foi pré determinada (ou direcionada). Não foi utilizada a metodologia proposta por Meihy (1996), sobre uma sondagem, para determinar a escolha da primeira pessoa ou grupo, "colônia" de entrevistados; 
2. A elaboração das entrevistas foi realizada através de perguntas semiestruturadas com a técnica de questões abertas, que têm por objetivo que o entrevistado desenvolva seu pensamento expressando-o como um discurso. O roteiro de perguntas sofreu alterações ao longo das entrevistas, com alguns acréscimos;

3. A conferência dos textos tratou-se de uma edição que, segundo Meihy (1996), é o ponto central da verificação dos procedimentos das entrevistas. Uma negociação do que será publicado ou não, acertos de datas, das falhas da memória. São confirmações e correções gramaticais, de informações e acréscimos de outros dados que não foram contemplados na entrevista, tanto pelos entrevistados, quanto pelo entrevistador;

4. Feitura dos textos. As entrevistas foram estudadas individualmente e contextualizadas para serem utilizadas na pesquisa, inserindo o conteúdo relevante de informações no texto final. Os documentos finais foram anexados ao trabalho;

5. Guarda do material. O consentimento do uso e veiculação do material das entrevistas no trabalho acadêmico foi feito através de uma carta de cessão de uso (anexo II), informando-os sobre os locais aonde ficarão depositados os trabalhos para utilização pública;

6. Uma cópia do texto final das entrevistas foi devolvida a cada um dos entrevistados.

A metodologia utilizada para o biomapa compreendeu:

1. Apresentação dos participantes (da comunidade e dos aplicadores): de qual bairro, sua relação com o parque e com a comunidade local, o que elas esperavam daquele processo. Com uma explicação sobre o biomapa:

1.1 Qual era a meta para o mapeamento;

1.2 Quais eram os objetivos;

1.3 Onde este conhecimento poderá ser aplicado;

1.4 Como poderá ser utilizado.

2. Apresentação de um "vídeo" - uma projeção de imagens do Parque do Pedroso; 
3. Um mapa base na escala 1:5.000, uma foto aérea e figuras - simbologia para facilitar a execução dos mapeamentos em tempo curto para realização da oficina;

4. Formação de três grupos para o mapeamento de temas como: biofísico, histórico e conflitos;

5. Orientação sobre a participação da comunidade no processo: regras, tempo necessário, possibilidades para futuros projetos, como os mapas seriam utilizados e para quem estarão disponíveis as informações levantadas após o processo;

6. Apresentação dos mapeamentos ao grupo participante: discussões sobre assuntos mais importantes e o levantamento das propostas sobre o futuro (continuidade das discussões);

7. Os mapas finais ficaram depositados na GEMA - Gerência de Educação e Mobilização Ambiental do SEMASA.

As entrevistas, assim como o biomapa, trouxeram diferentes perspectivas, "olhares" e saberes distintos sobre o tema. Foi uma contribuição fundamental para o desenvolvimento do trabalho e, mais do que a simples coleta de opiniões e entendimentos variados sobre o parque, foram mostrados caminhos para a pesquisa, indicando determinados problemas que precisavam ser aprofundados sobre a condição da mata, a biodiversidade, conflitos para a gestão, entre a legislação e sua condição urbana; carências de lazer e de conhecimento da população e, sobretudo, explicitaram a complexidade do tema, que não pode ser tratado dentro de visões técnicas, específicas, apenas. 


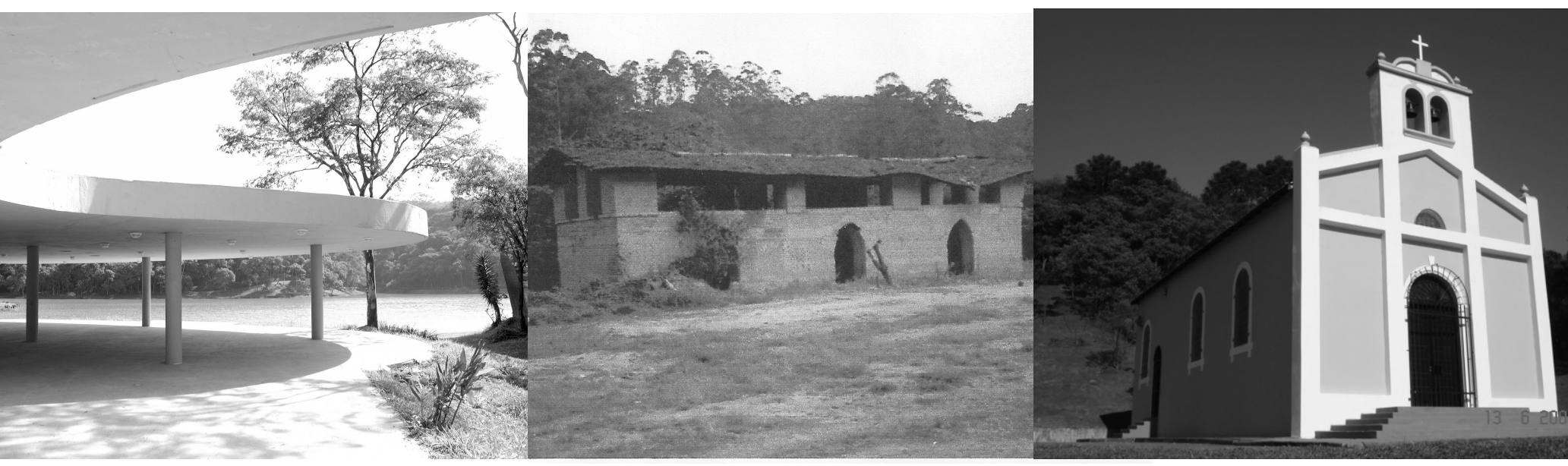

\section{Capítulo I}

Aspectos históricos da formação de Santo André e região 


\section{A região}

Composta por sete municípios - Santo André, São Bernardo do Campo, São Caetano do Sul, Mauá, Diadema, Ribeirão Pires e Rio Grande da Serra -, a região do Grande $A B C$ forma um aglomerado de cidades com uma malha viária interligada, criando uma paisagem urbana contínua (exceto Rio Grande da Serra).

Tem na sua história, o princípio da formação do que caracteriza hoje um território regional, que além do caráter físico-territorial (biofísico), apresenta aspectos econômicos e político-administrativos comuns. ${ }^{3}$

Entre os séculos XVI e XIX, ocorreram várias mudanças de delimitação geográfica e sede: da Vila de Santo André da Borda do Campo até a definição atual dos municípios do Grande ABC.

"A região onde se localiza o Município de Santo André, à borda do planalto, era cortada por uma trilha tupiniquim que conduzia ao mar. $A$ partir da segunda metade do Século XVI, esta via passou a ser utilizada pelos portugueses em sua faina de catequizar, povoar e garantir a posse da terra. É possível que já a esta época tivessem se instalado pequenas roças em torno da passagem"(Rodrigues, 1991:14).

O primeiro povoamento, a Vila de Santo André da Borda do Campo, foi criado pelo Governador Geral Tomé de Souza em 1553 como unidade municipal do planalto paulista e, segundo Wanderley dos Santos (1992), localizava-se ao sul do atual município de Santo André, no Vale do Ribeirão Guarará, na altura dos loteamentos do Jardim Santo André e Vila João Ramalho, além da Vila Luzita.

\footnotetext{
3 A região está inserida na Unidade de Gerenciamento de Recursos Hídricos - UGRHI 6-Alto Tietê -, que reúne um conjunto de bacias hidrográficas. O bioma da Mata Atlântica está presente na forma de fragmentos florestais em quase todos os municípios, com exceção da cidade de São Caetano do Sul, totalmente urbanizada. Do ponto de vista político-administrativo, não há uma lei específica para 0 Grande ABC, sendo esta a sub-região sudeste da Região Metropolitana de São Paulo - RMSP -, criada pela Lei Federal complementar $n^{\circ}$ 14/1973 com base na Emenda 1/69 da Constituição Federal de 1967. Nas décadas de 1940 e 1950 surgiram consórcios e convênios intermunicipais buscando soluções conjuntas para as áreas de transporte, saneamento, retificação de córregos de divisas etc. Em 1960 foi criada a Comissão Intermunicipal de Controle da Poluição das Águas e do Ar (CICPAA), com atuação em Santo André, São Bernardo, São Caetano do Sul e Mauá, em 1970 foi incorporado pela SUSAM - Superintendência de Saneamento Ambiental - e em 1975, pela CETESB. O Consórcio das bacias do Alto Tietê e Billings foi criado em 1990, reunindo os sete municípios em torno de definições de políticas comuns para o desenvolvimento da região.

Em 1997 o Consórcio Intermunicipal do grande ABC apontava para uma regionalização do planejamento dos municípios (Klink, 2001).
} 
A falta de proteção e dificuldades com a subsistência fez com que a Vila de Santo André fosse transferida para a Aldeia São Paulo de Piratininga em 1560, onde hoje está a cidade de São Paulo. A região permaneceu como um bairro rural de São Paulo, estrategicamente localizado ao lado da passagem para o litoral, que fazia a ligação entre o Porto de Santos, a capital e o interior.

Duas fazendas, São Caetano e São Bernardo, foram formadas no primeiro quartel do século XVII em parte das glebas que passaram a pertencer à Capitania de São Vicente, e uma porção dessas terras foi doada a monges beneditinos da ordem de São Bento. Essas fazendas ocupavam grande área dos atuais municípios de mesmo nome. Ao redor da Fazenda São Bernardo formou-se um pequeno núcleo urbano, que em 1889 garantiria a criação do município de São Bernardo.

A implantação, em 1867, da Estrada de Ferro Santos-Jundiaí, a São Paulo Railway Company (SPR) em áreas próximas ao rio Tamanduateí e a criação das colônias em 1877 de imigrantes predominantemente de origem italiana nas terras das Fazendas dos monges beneditinos, os Núcleos Coloniais de São Caetano, São Bernardo e ainda o Núcleo Colonial da Borda do Campo (de Ribeirão Pires), estão relacionados ao desenvolvimento da Província de São Paulo que iniciava a produção cafeeira, quando o centro de poder econômico se deslocava do Rio de Janeiro para São Paulo ${ }^{4}$. A ferrovia visava facilitar o escoamento de produtos agrícolas, especialmente o café do interior, à Província de São Paulo e ao Porto de Santos.

As colônias de imigrantes foram criadas pelo Governo Imperial, para desenvolvimento da produção agrícola em pequenas propriedades voltadas ao cultivo de produtos de subsistência para apoio às fazendas de café. Essa utilização das terras fracassou por "más condições de vida e inaptidão das terras para cultivo", obrigando os imigrantes a buscarem outras opções de trabalho no núcleo urbano ou em grandes propriedades agrícolas como mão de obra barata (Santo André, 2008a).

No entorno da estação ferroviária de São Bernardo (atual estação prefeito Celso Daniel) formou-se um povoamento, correspondendo hoje ao centro da cidade de Santo André. Foi elevado à categoria de Distrito em 1910, e em 1939 tornou-se Município de Santo André, passando a ser também sede do poder político e administrativo de toda a região do Grande $A B C$, o que até então, era atribuição do

\footnotetext{
4 "O definitivo deslocamento do eixo dinâmico da economia nacional, só iria ocorrer em torno de 19101920" (Klink, op. cit.:93).
} 
Município de São Bernardo. Reuniu vários distritos que nos anos seguintes foram se emancipando e configurando os municípios que hoje formam a região do Grande ABC: São Bernardo do Campo (1945), São Caetano do Sul (1949); Mauá e Ribeirão Pires (1953). Mantiveram-se os Distritos, Sede, Capuava e Paranapiacaba (Santo André, 2008a). 


\section{A produção rural da região}

A experiência agrícola da região que hoje compreende o Grande $A B C$ aproxima-se do que Sérgio Buarque de Holanda descreveu como resultado do declínio dos centros de produção agrária no Brasil, ocorrido na metade do século XIX. A alteração da economia baseada na produção canavieira para cafeeira, criando uma aristocracia rural poderosa, levou ao enfraquecimento dos centros rurais e isso, segundo esse autor, foi o fator decisivo para nossa "hipertrofia urbana".

Não houve uma produção rural expressiva na região a ponto de colocá-la num patamar de localidade agrária de destaque, mas o atrelamento econômico à província de São Paulo, que se abastecia da produção agrícola da região, em grande medida enquadra-se no papel complementar a serviço da cidade:

"As cidades, que outrora tinham sido como complementos do mundo rural, proclamam finalmente sua vida própria e sua primazia. Em verdade podemos considerar dois movimentos simultâneos e convergentes através de toda a nossa evolução histórica: um tendente a dilatar a ação das comunidades urbanas e outro que restringe a influência dos centros rurais, transformados em simples fontes abastecedoras, em 'colônias' das cidades (...)" (Holanda, 1989:128).

O desenvolvimento econômico da região do Grande $A B C$, desde sua origem, sempre esteve intrinsecamente ligado ao de São Paulo, inicialmente como passagem para o escoamento de gêneros e produtos das regiões mais próximas e o açúcar fabricado no interior que São Paulo exportava desde a segunda metade do século XVIII (Rodrigues, 1991).

Muito embora houvesse uma produção agrícola, um Relatório do Município de São Bernardo (1928:9) descrevia os terrenos no entorno de Santo André e São Caetano como "não prestando para a agricultura". Segundo Passarelli (1990), as más condições de clima e solo para o desenvolvimento de atividades agrícolas indicavam a vocação industrial da região e considerou a primeira atividade industrial, já em 1758, voltada ao beneficiamento da matéria prima, a produção de telhas e tijolos pela Olaria da Fazenda São Caetano, dos beneditinos. 
Dentre as descrições sobre as atividades produtivas desenvolvidas na região, tem-se a extração de lenha para produção de carvão, e agricultura e pecuária nos séculos XVIII e XIX. A agricultura era voltada para subsistência e também comercializada na região, com produtos como mandioca, milho, arroz e feijão e um pouco de cana-de-açúcar para a produção de água ardente. A criação de animais como bois, potros e bestas era voltada para o transporte, atendia aos trabalhos na lavoura e ao transporte de tropeiros $^{5}$, que levavam mercadorias de Santos para a Província e para o interior.

As fazendas dos beneditinos e a produção de chá de Francisco Martins de Bonilha foram as exceções à agricultura de subsistência, quando foi mais significativa e diversificada com produtos como laranja, marmelo, farinha, azeite de amendoim, feijão e arroz, e ainda atividades extrativistas de madeira, a fabricação de carvão e criação de gado 'Santo André, 2008a).

Houve a produção de chá por volta de 1839 por Francisco Martins de Bonilha, figura destacada politicamente que possuía o título de alferes e ocupou o cargo de vereador da capital, deputado da província e foi um inovador da agricultura regional com a tentativa de exportação do chá chinês (Rodrigues, 1991).

Houve também o plantio de videiras para a produção de vinho nos núcleos coloniais, onde predominou a imigração italiana, que se manteve até 1888 no núcleo de São Caetano e 1893 em São Bernardo, quando uma praga (phyloxera) atingiu e arrasou as plantações, que foram substituídas, como alternativa, pela extração de madeira e a produção de carvão (Scifoni, 1994).

Gaiarsa (1991) descreve rebanhos de gado leiteiro como uma atividade desenvolvida na região por volta de 1919, cuja produção era vendida de porta em porta. Em um relatório de São Bernardo do mesmo ano, há a descrição dessa atividade (indústria pastoril) como uma possibilidade de produção (leite) a ser incrementada, dada as condições favoráveis que existiam no município (tanto os pastos quanto a oferta de alimentação aos animais com a produção local). Esse desenvolvimento dependeria da iniciativa dos criadores.

No início do século, já tendo a primeira Lei de parcelamento do solo $n^{\circ} .271$ de 1929, a ampliação de oferta de trens de passageiros estimulava a venda de lotes próximos à estação, e os mais distantes eram loteados para uso rural (Vila

\footnotetext{
${ }^{5}$ Foi uma atividade de grande importância na dinâmica da região devido ao intenso trânsito das tropas, que alugavam pastagens e pouso. Alguns tropeiros moravam na região (Santo André, 2008a).
} 
Homero Thon, Vila Curuçá, Vila Utinga e Vila Olga) (Santo André, 2004). Esses lotes rurais possuíam área superior a $1.000 \mathrm{~m}^{2}$ (Passarelli, 1994).

A atividade rural da região na década de 1940 tendia à extinção com o avanço da urbanização - como explica Gaiarsa (1991). Naquele momento se restringia a produção de hortaliças pela Colônia Japonesa ${ }^{6}$, que eram cultivadas próximas a cursos d'água e também ovos em granjas atendendo a região do $A B C$. Os lotes rurais e as chácaras de lazer, que predominaram até então, foram parcelados, cedendo espaço ao avanço urbano.

Na década de 1950, Médici (1992) descreve o território ao longo da estrada do Pedroso, depois da Vila Luzita, como sendo a última área rural de Santo André, com cerca de 11 olarias.

1. Antigo forno de olaria demolido, na região norte do Parque do Pedroso. Foi uma olaria particular e depois pertenceu à Prefeitura Municipal de Santo André, produzindo tijolos para o município. No seu entorno existiram várias moradias, até o ano de 2010, quando as famílias foram retiradas e as residências demolidas para dar lugar a um viveiro de mudas de árvores nativas.

Fonte: DGA - SEMASA, 2003.

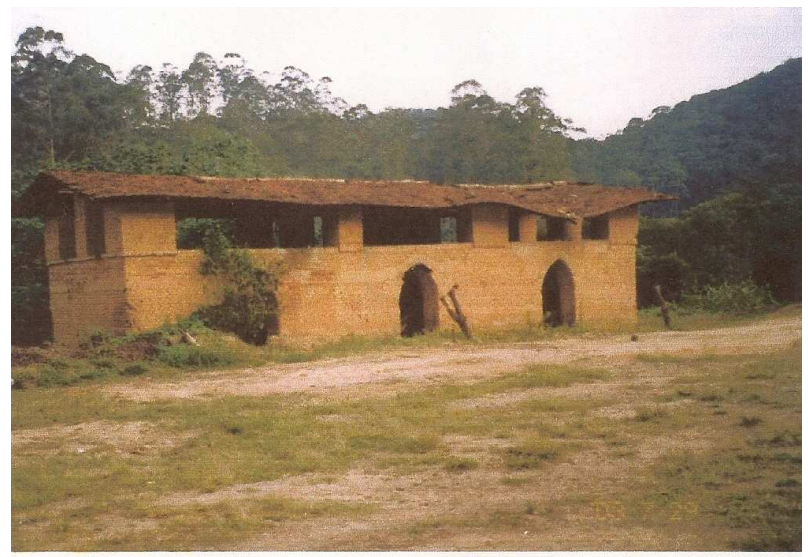

A Lei Municipal № 1.862, de 21 de agosto de 1962, criou o Imposto Territorial Rural sobre todos os terrenos localizados na então Zona Rural do município, compreendendo atualmente a Macrozona de Proteção Ambiental ${ }^{7}$. O Horto Municipal do Pedroso estava no limite de tal zona.

Essa denominação foi alterada no Plano Diretor (Lei Municipal no 7.333, de 26 de dezembro de 1995), que gravou a área rural como 'zona de expansão urbana', contrariando a legislação estadual de proteção aos mananciais que já vigorava desde a década de 1970.

As chácaras de pequeno e grande porte ainda subsistem na região sudeste do município, na Área de Proteção e Recuperação dos Mananciais (APRM) - Macrozona de Proteção Ambiental -, compreendendo os bairros Jardim Clube de Campo, Sítio Taquaral, Chácaras Engenho da Serra e Fazenda dos Tecos. Ao sul

\footnotetext{
${ }^{6}$ Imigrantes que chegaram até meados da década de 1920: portugueses, espanhóis, alemães, austríacos, iugoslavos, romenos, lituanos, sírio-libaneses e japoneses (Rodrigues, 1991).

${ }^{7}$ Lei no 8.696 , de 17 de dezembro de 2004.
} 
do braço do Rio Pequeno, chácaras de alto padrão, formadas pelos bairros Jardim das Garças e Parque das Garças e, na outra margem, mais chácaras de pequeno e grande porte mescladas com habitações de baixo padrão e barracos, nos bairros Jardim Guaripocaba, Parque Rio Grande, Alto Rio Pequeno (UMAH, 2000:134).

Em Santo André, a divisão territorial atual foi definida pelo Plano Diretor (Lei $n^{\circ}$ 8.696/2004), que considerou as características dos ambientes natural e construído, delimitando duas macrozonas complementares: a urbana e a de proteção ambiental, sendo esta última correspondente às Áreas de Proteção e Recuperação dos Mananciais (APRM) que o Pedroso integra. 


\section{A expansão urbana}

Entre as décadas de 1920 e 1940 houve uma grande expansão urbana, tendo as estações ferroviárias como centros e a linha férrea como um eixo principal de adensamento urbano (Passarelli, 1990).

Nos anos quarenta e início dos anos cinquenta, na região do $A B C$, inicia-se uma intensificação do processo de desenvolvimento econômico com foco na industrialização, que promoveu uma acelerada transformação e, em pouco tempo, a faixa São Caetano-Santo André passou a ser a mais importante zona industrial e a mais populosa de todos os arredores paulistanos. A ocupação urbana em 1950 avançou sobre antigos caminhos e estradas e foi se afastando das várzeas do rio Tamanduateí, um vetor de ocupação predominante do final do século XIX até meados do século XX, estimulado pela atividade industrial. Tomou a direção norte e sul $^{8}$, ocupando fundos de vales e terrenos com alta declividade - regiões com maiores carências em infraestrutura e equipamentos (no vale dos córregos Apiaí, Guarará, Cassaquera e expandiu-se na região de Capuava).

Nesse período de intenso desenvolvimento econômico e crescimento vertiginoso da população urbana, é importante ressaltar algumas das características do processo de urbanização. Maricato aponta para (i) a industrialização com baixos salários, combinada com o mercado imobiliário restrito na cidade de São Paulo, nos anos de 1990, atingiam cerca de $40 \%$ da população, restando aos $60 \%$ soluções como cortiços de aluguéis, as favelas e os loteamentos ilegais, já que a promoção pública não chegava a impactar o mercado devido à baixa oferta de moradias resultante das políticas sociais; (ii) gestões urbanas com tradição em investimento regressivo, ou seja, as obras de infraestrutura urbana alimentavam a especulação fundiária e não a democratização do acesso à terra para moradia.

Proprietários de terra, empresas de promoção imobiliária e construtoras formavam grupos reais de poder e de definição das realizações orçamentárias municipais - a valorização das propriedades fundiárias ou imobiliárias foi o motor que movia e orientava a localização dos investimentos públicos, especialmente na circulação viária -; (iii) legislação ambígua ou aplicação arbitrária da lei: "a notável

\footnotetext{
${ }^{8}$ Corresponde à Unidade Ambiental Natural. Localiza-se ao sul da área mais urbanizada do município e se estende a toda a Área de Proteção e Recuperação dos Mananciais, incluindo do Parque do Pedroso até a região de Paranapiacaba. Dessa área deve-se subtrair os rios Grande e Pequeno (Santo André, 2004).
} 
desigualdade urbanística é uma construção que tem na aplicação arbitrária da lei sua argamassa fundamental" apud Moreno (2004), numa realidade onde a ocupação de terras era tolerada pela sociedade e o estado não exercia seu papel de polícia. Entretanto, essa tolerância ocorria apenas em locais onde não havia interesse do mercado imobiliário, justamente nas áreas com restrições legais, pela fragilidade ambiental, como as áreas de preservação permanente (APP) ${ }^{9}$ e as áreas de proteção aos mananciais.

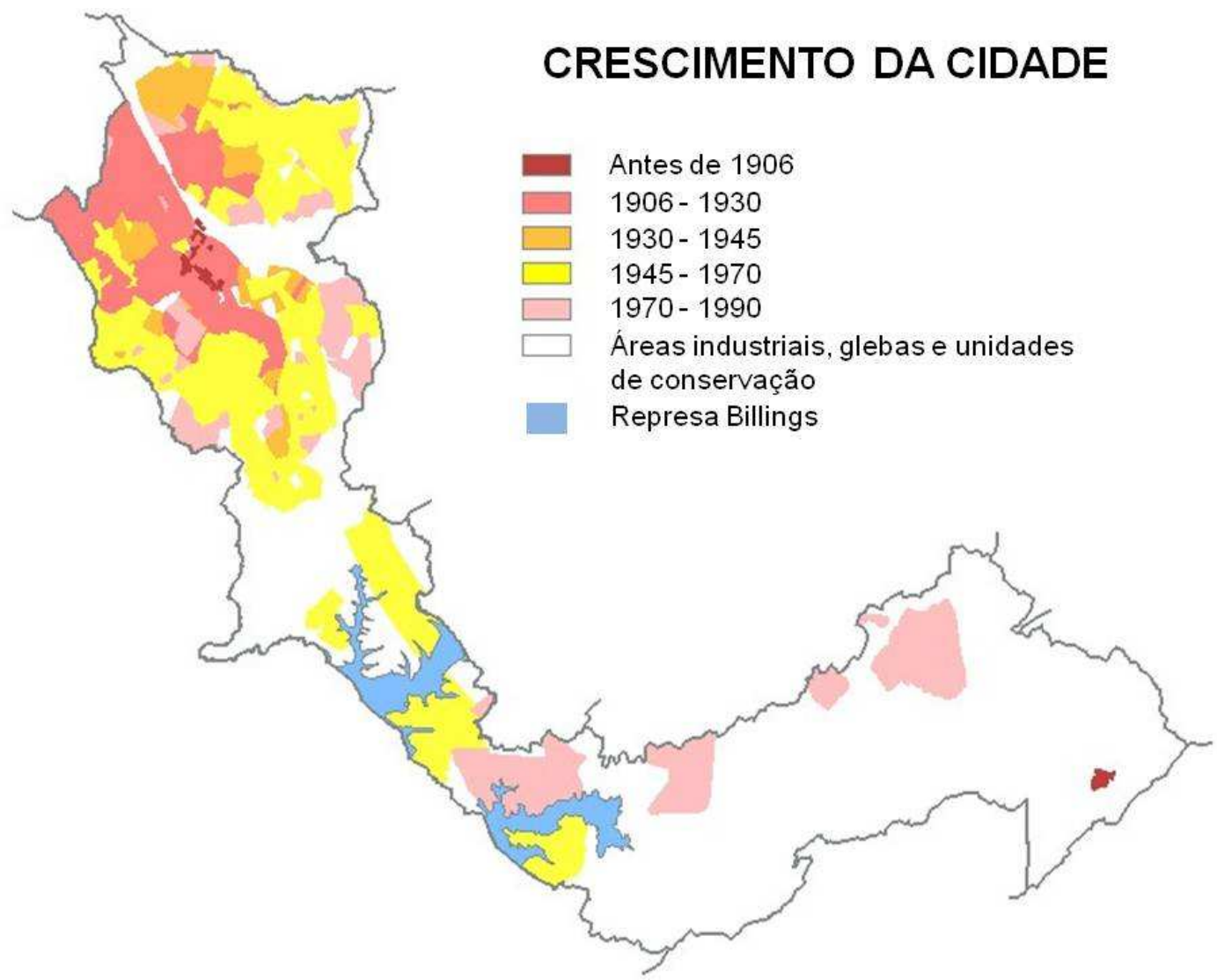

Figura 1: Crescimento urbano de Santo André.

Fonte: Departamento de Indicadores Sociais e Econômicos / PSA, 2007.

\footnotetext{
${ }^{9}$ De acordo com o Código Florestal brasileiro (Lei no 4.771, de 15 de setembro de 1965) as Áreas de Preservação Permanente (APPs) são áreas “...cobertas ou não por vegetação nativa, com a função ambiental de preservar os recursos hídricos, a paisagem, a estabilidade geológica, a biodiversidade, 0 fluxo gênico de fauna e flora, proteger o solo e assegurar o bem-estar das populações humanas". Exemplos de APPs são as áreas marginais dos corpos d'água (rios, córregos, lagos, reservatórios), áreas num raio de cinquenta metros em torno de nascentes, áreas de topo de morros e montanhas, áreas em encostas acentuadas, restingas e mangues, entre outras. As definições e limites de APPs são apresentadas, em detalhes, na Resolução CONAMA n 302 de 20/03/2002 (Skorupa, 2003).
} 
Surgiram as primeiras favelas ${ }^{10}$ em Santo André no final da década de 1960, quando, apenas em uma década, o forte crescimento populacional atinge quase $50 \%$. Nesse período, houve um processo de migração atraída pelos empregos na indústria e, mais tarde, na década de 1980, pelos empregos oferecidos na construção civil e pelas obras públicas (Sonto André, 1991).

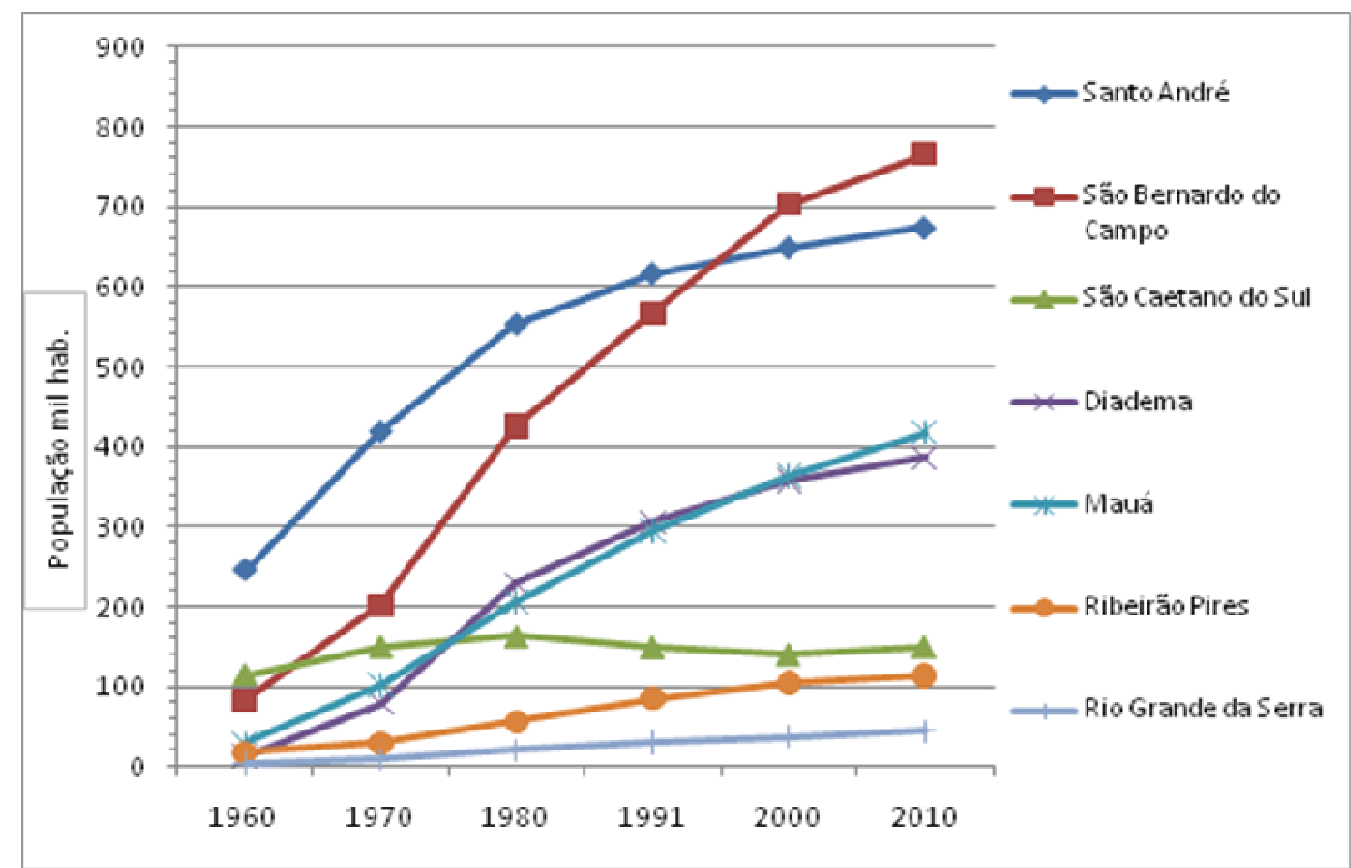

Gráfico 1: Crescimento da população das cidades do Grande ABC entre 1960 e 2010.

Elaborado por Robson S. Moreno.

Houve o aumento do adensamento populacional e das favelas que em geral, ocuparam reservas para áreas verdes dos loteamentos da cidade implantados a partir dos anos 1950 (áreas públicas), avançando para os fundos de vales e terrenos com altas declividades, “(...) refletindo no espaço físico o aprofundamento das distinções sociais (...)"(Santo André, 1991:109).

\footnotetext{
${ }^{10}$ Segundo Maricato (apud Moreno, op. cit.), a definição de favela passa pela questão da ilegalidade da propriedade do lote que, dependendo da localidade, tem outra denominação, como por exemplo: em Porto Alegre são conhecidas como "vilas", em Goiânia "áreas de posse", em Santo André, também são conhecidas como "núcleos habitacionais". O Plano Municipal de Habitação define favela como "todos os assentamentos precários, em áreas públicas ou privadas, que, independente do grau de precariedade das condições de habitação e de oferta de infraestrutura básica, sejam ocupadas por não-proprietários (mais de um núcleo familiar), sobre as quais os moradores edificaram casas à margem dos códigos legais de parcelamento e edificação, independente do número de domicílios e do material empregado nas construções, e onde não se caracteriza a existência de agente promotor e/ou comercializador e tampouco a existência de plano de ocupação pré-fixado"(Santo André, 2006:109).
} 
Núcleos habitacionais precários (favelas) no entorno do Parque do Pedroso, somados aos bairros regulares, representam uma população de 42.929 habitantes.

Entre as décadas de 1950 e 1970, houve uma grande expansão e adensamento populacional na cidade de Santo André, repetindo-se nas cidades vizinhas, o que desenvolveu uma rede viária e uma malha urbana contínua. Essa tendência à conurbação já era observada em 1928 entre as cidades (Distritos) de Santo André e São Caetano: "Ambas crescem com a mesma intensidade e com tendências a se encontrarem formando uma só agglomeração (...)” (Relatório, 1928).

Em atendimento a uma demanda reprimida de carência de habitação, as Leis Municipais $n^{\text {os }} 6.540$ e 6.598 , ambas de 1989 , determinaram diretrizes para a construção de conjuntos habitacionais de interesse social que foram permitidos em toda a cidade, com exceção da área que já estava em processo de verticalização os bairros mais abastados da cidade. Muitos desses conjuntos foram implantados na porção sul da cidade, uma região já bastante adensada com carências de equipamentos públicos (Vila Suiça, Guarará, Vila Luzita etc.), (Passarelli, 1994).

\begin{tabular}{|c|c|c|c|c|c|c|c|c|}
\hline \multirow[t]{2}{*}{ BAIRRO } & \multirow[t]{2}{*}{ Ano* } & \multirow[t]{2}{*}{ Área $\left(\mathrm{km}^{2}\right)$} & \multirow{2}{*}{$\begin{array}{c}\text { N.o de } \\
\text { Domicílios' }\end{array}$} & \multicolumn{2}{|c|}{ População ${ }^{2}$} & \multirow{2}{*}{$\begin{array}{c}\text { Crescimento } \\
(96-00)\end{array}$} & \multicolumn{2}{|c|}{ Projeção** } \\
\hline & & & & 1996 & 2000 & & 2005 & 2009 \\
\hline Cata Preta & & 1,34 & 1.491 & 171 & 5.587 & $3167,25 \%$ & 5.748 & 5.870 \\
\hline Jardim Vila Rica & & 0,16 & 383 & 1.536 & 1.428 & $-7,03 \%$ & 1.469 & 1.500 \\
\hline Jardim Irene & 1951 & 0,41 & 1.802 & 5834 & 6.435 & $10,30 \%$ & 6.621 & 6.762 \\
\hline Jardim Santo André & 1953 & 2,11 & 7.897 & 9318 & 29.818 & $220,00 \%$ & 30.677 & 31.329 \\
\hline Vila João Ramalho & & 0,74 & 2.210 & 5604 & 8.302 & $48,14 \%$ & 4.361 & 4.454 \\
\hline Jardim Riviera & & 0,77 & 688 & 1775 & 3.280 & $84,79 \%$ & 2.598 & 2.653 \\
\hline Parque Miami & & 0,98 & 963 & 3959 & 3.708 & $-6,34 \%$ & 3.814 & 3.895 \\
\hline $\begin{array}{l}\text { Recreio da Borda do } \\
\text { Campo }\end{array}$ & 1976 & 3,53 & 2.099 & 3209 & 8.025 & $150,08 \%$ & 8.257 & 8.432 \\
\hline
\end{tabular}

Tabela 1: Características dos bairros do entorno do Parque do Pedroso. Org. Robson S. Moreno.

${ }^{1}$ Número de domicílios segundo Censo de 2000 do IBGE

2 População segunda a recontagem de 1996 e o Censo de 2000 do IBGE

*Ano de abertura dos loteamentos

** Projeção segundo o SEADE e DISE/SOPP/PSA

Na década de 1970, a ocupação em novas áreas do município diminuiu os vazios urbanos e a expansão atingiu seu limite, levando a ocupação em direção à Represa Billings, ao sul do Município. Formaram-se os bairros na área de mananciais, no entorno do Parque do Pedroso, denominado nessa época como Parque Florestal do Reservatório do Pedroso (Horto Municipal). Foram os bairros 
Parque Miami, Jardim Riviera e Jardim Recreio da Borda do Campo. Sob a denominação "Cidade Recreio da Borda do Campo"11", este último bairro foi projetado com lotes entre 500 a $2.000 \mathrm{~m}^{2}$, (propriedade de Melhoramentos Virgínia Ltda.) e implantado antes da promulgação da Lei Estadual $n^{0} 1.172$, de 17 de novembro de 1976, que delimitou as áreas de proteção aos mananciais, cursos e reservatórios de água de interesse da Região Metropolitana da Grande São Paulo, estabelecendo normas de restrição de uso do solo em tais áreas. No início de 1970, os lotes já eram comercializados por uma imobiliária (Santo André, 1992).

Atualmente, o loteamento não mantém as características do projeto original (com baixa densidade proporcionada pelo padrão de divisão dos lotes proposto), formado por pequenas chácaras. Sofreu várias subdivisões irregulares, provocando um adensamento superior ao que preconizava a legislação sobre a baixa ocupação em áreas de mananciais. ${ }^{12}$ Somente no Plano Diretor atual que a Legislação Ambiental Estadual sobre proteção dos mananciais foi incorporada na Lei municipal, no Plano de 1995, essas áreas eram consideradas de expansão urbana.

Os bairros Parque Miami e Jardim Riviera estão em Áreas de Ocupação Dirigida $^{13}$ e foram implantados, segundo Medici (op.cit.), no final da década de 1960, como loteamentos irregulares em terras da família Pedroso, que possuía 100 alqueires. Da mesma forma que o bairro Recreio da Borda do Campo, estes dois bairros surgiram antes da promulgação da lei de proteção das áreas de mananciais e da aprovação dos loteamentos em referência pelo município. ${ }^{14}$

\footnotetext{
${ }^{11}$ Denominação que consta na planta heliográfica do loteamento nos padrões da Prefeitura Municipal de Santo André com data de 16 de setembro de 1976 (Arquivo GEPLAN-SEMASA).

${ }_{12}$ Essa premissa da Lei 1.172/1976 foi alterada pela Lei específica da Billings, $n^{\circ}$ 13.579/2009, quanto aos parâmetros de ocupação que permitem índices urbanísticos que favorecem um maior adensamento populacional na Área de Proteção e Recuperação de Mananciais da Bacia Hidrográfica do reservatório Billings. Muito embora, os impedimentos impostos pelas Áreas de Preservação Permanentes de córregos, rios e topos de morro ainda permanecem, impondo limites a esse adensamento.

${ }^{13}$ Classificação definida na Lei específica da Billings, Lei 13.579, de julho de 2009, seção II, art. 20 AOD (Áreas de Ocupação Dirigida): "são áreas de interesse para a consolidação ou implantação de uso urbano ou rural, desde que atendidos os requisitos que assegurem a manutenção das condições ambientais necessárias à produção de água em quantidade e qualidade para o abastecimento público." Os bairros compreendem a Subárea de Ocupação Urbana Consolidada (SUC), art. 21 "área com ocupação urbana irreversível e servidas parcialmente por infraestrutura, inclusive de saneamento ambiental e serviços urbanos."

${ }^{14}$ Lei Municipal 5.823/1981. Aprova os loteamentos Parque Miami e Jardim Riviera.
} 


\begin{tabular}{|c|c|c|c|c|c|c|c|c|}
\hline & \multicolumn{2}{|c|}{ Assentamentos } & $\begin{array}{c}\text { Ano } \\
\text { da } \\
\text { Inf. }\end{array}$ & Fonte & $\begin{array}{c}\text { Qtde. de } \\
\text { domicílios }\end{array}$ & $\begin{array}{l}\text { Área Total } \\
\left(\mathrm{m}^{2}\right)\end{array}$ & $\begin{array}{l}\text { Área Total } \\
\text { (ha) }\end{array}$ & $\begin{array}{l}\text { Densidade } \\
\text { (dom./ha) }\end{array}$ \\
\hline \multirow{15}{*}{ 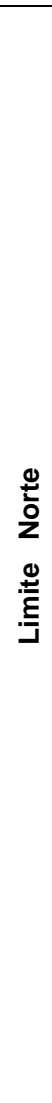 } & \multicolumn{2}{|r|}{ André Magini } & 2000 & $\begin{array}{c}\text { Estimativa } \\
\text { DEHAB }\end{array}$ & 31 & $2.360,00$ & 0,236 & 131,356 \\
\hline & \multicolumn{2}{|c|}{ Bartolomeu Dias } & 2004 & $\begin{array}{c}\text { Contagem } \\
\text { DEHAB }\end{array}$ & 93 & $6.879,00$ & 0,688 & 135,194 \\
\hline & \multicolumn{2}{|r|}{ Conjunto Vitória } & 2002 & $\begin{array}{c}\text { Contagem } \\
\text { DEHAB }\end{array}$ & 64 & $7.740,00$ & 0,774 & 82,687 \\
\hline & \multicolumn{2}{|r|}{$\begin{array}{l}\text { Cata Preta } \\
\text { Eucaliptos }\end{array}$} & 2004 & $\begin{array}{c}\text { Estimativa } \\
\text { DEHAB }\end{array}$ & 350 & $32.087,97$ & 3,209 & 109,075 \\
\hline & \multicolumn{2}{|r|}{ Cata Preta I } & 2001 & $\begin{array}{l}\text { Pesq. } \\
\text { DEHAB }\end{array}$ & 63 & $11.258,00$ & 1,126 & 55,960 \\
\hline & \multicolumn{2}{|r|}{ Cata Preta II } & 1997 & $\begin{array}{l}\text { Pesq. } \\
\text { DEHAB }\end{array}$ & 929 & $103.891,98$ & 10,389 & 89,420 \\
\hline & \multicolumn{2}{|c|}{ Complexo Jd. Irene } & 2005 & $\begin{array}{l}\text { Pesq. } \\
\text { DEHAB }\end{array}$ & 1.651 & $226.000,00$ & 22,600 & 73,053 \\
\hline & \multicolumn{2}{|c|}{ Jd. dos Pássaros } & 2004 & Contagem & 68 & $9.340,00$ & 0,934 & 72,805 \\
\hline & \multirow{6}{*}{ 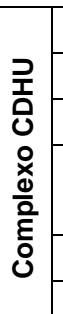 } & Campineiros & \multirow{6}{*}{2005} & \multirow{6}{*}{$\begin{array}{c}\text { Estimativa } \\
\text { CDHU }\end{array}$} & \multirow{6}{*}{4.164} & \multirow{6}{*}{$831.418,85$} & \multirow{6}{*}{83,142} & \multirow{6}{*}{50,083} \\
\hline & & Cruzado II & & & & & & \\
\hline & & \begin{tabular}{|l} 
Dominicanos \\
\end{tabular} & & & & & & \\
\hline & & $\begin{array}{l}\text { Lamartine } \\
\text { (CDHU) }\end{array}$ & & & & & & \\
\hline & & Missionários & & & & & & \\
\hline & & Toledanas & & & & & & \\
\hline & & Total - Norte & & & 7.413 & $1.230 .975,80$ & & \\
\hline \multirow{4}{*}{ 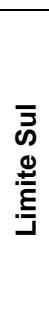 } & \multicolumn{2}{|c|}{ Núcleo Pintassilgo } & 2002 & $\begin{array}{l}\text { Pesq. } \\
\text { DEHAB }\end{array}$ & 1.283 & $252.000,00$ & 25,200 & 50,913 \\
\hline & \multicolumn{2}{|c|}{ Rio Corumbiara } & 1999 & $\begin{array}{c}\text { Estimativa } \\
\text { DEHAB }\end{array}$ & 25 & $3.750,00$ & 0,375 & 66,667 \\
\hline & \multicolumn{2}{|r|}{ Rio Mearim } & 1999 & $\begin{array}{c}\text { Contagem } \\
\text { DEHAB }\end{array}$ & 5 & 750,00 & 0,075 & 66,667 \\
\hline & \multicolumn{2}{|r|}{ Total - Sul } & & & 1.313 & $256.500,00$ & & \\
\hline & \multicolumn{4}{|c|}{ Total Norte+Sul } & 8.726 & $1.487 .475,80$ & 122,86158 & \\
\hline & \multicolumn{4}{|c|}{ Percentual em relação ao total municipal } & $30,3 \%$ & $43,6 \%$ & $36,0 \%$ & \\
\hline & \multicolumn{4}{|c|}{$\begin{array}{l}\text { Totais de todos os assentamentos da } \\
\text { cidade }\end{array}$} & 28.772 & $3.413 .871,81$ & 341,387 & \\
\hline
\end{tabular}

Tabela 2: Assentamentos precários do entorno do Parque do Pedroso - Limites norte e sul. Fonte: Plano Municipal de Habitação, 2006. Org.: Robson S. Moreno. 
Em 1981, o Bairro Miami já possuía 60\% de sua área ocupada (edificada), e o Jardim Riviera, com $80 \%$ de ocupação com residências de baixo padrão construtivo, com boa porcentagem em condições precárias (barracos), sem infraestrutura básica, possuindo apenas energia elétrica ${ }^{15}$. Próximo aos loteamentos, em uma gleba ocupando os municípios de São Bernardo do Campo e Santo André, foi implantado o loteamento São Bernardo Novo.

A estimativa de ocupação para o Parque Miami, em 1981, era de 776 unidades, com população prevista para 3.880 habitantes, em uma área total de $388.477,50 \mathrm{~m}^{2}$. Para o Jardim Riviera, estimava-se um número de 449 unidades, com 2.245 habitantes, numa área total de loteamento de $224.933,40 \mathrm{~m}^{2}$. Para ambos os bairros foram planejados lotes de $500 \mathrm{~m}^{2}$, prevendo um padrão do 'tipo chácaras'. A realidade da ocupação contrariou esse padrão e os parâmetros definidos pela Lei Estadual para mananciais. Os loteamentos ainda carecem de regularização urbanística pelo Estado.

Ao sul do Parque do Pedroso, dentro de seus limites, surgiu um assentamento habitacional precário: a favela Pintassilgo (na área de uma antiga olaria). A ocupação irregular deste núcleo, com 1.200 famílias (cerca de $2.251^{16}$ pessoas), iniciou-se na década de 1990, com aproximadamente 500 hectares diretamente adjacentes às margens da Represa Billings e contíguos ao Parque Miami, ocupando uma área com declividade bastante acentuada (cerca de 50\%). Essa favela surgiu na mesma época da subdivisão legal do Parque Miami como uma expansão irregular.

Há um Termo de Ajustamento de Conduta $^{17}$ (TAC) assinado pela Prefeitura de Santo André, pela CDHU - Companhia de Desenvolvimento Habitacional e Urbano do Estado de São Paulo - e pelo Ministério Público Estadual para a retirada das famílias que estão dentro do parque, com prazo até o ano de 2012.

Esse núcleo foi objeto de estudo em um exercício acadêmico realizado em 2001, desenvolvido dentro do projeto Gerenciamento Participativo de Áreas de

\footnotetext{
${ }^{15}$ Processo $n^{0} 20.584$, de 26 de junho de 1981, PSA.

${ }^{16}$ Dados do IBGE. Censo demográfico de 2000 ( Santo André, 2008a).

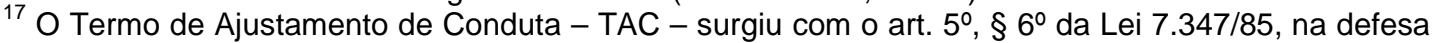
dos interesses difusos e coletivos, outorgou aos órgãos públicos que possuem legitimidade para ajuizar ação civil pública a possibilidade de tomarem do autor de comportamento lesivo a direitos transidividuais o compromisso de ajustamento de sua conduta às exigências legais (Leite, 2009).
} 
Mananciais de Santo André - GEPAM $^{18}$-, em conjunto com a FAU-USP, para tentar dar respostas às questões de ordem ambiental e legal (TAC), projetando uma comunidade sustentável em uma área de manancial ambientalmente sensível. Sem os desdobramentos pretendidos na ocasião da realização desse trabalho, mas com expectativas lançadas para a população, o assentamento aguarda as definições do município.

\footnotetext{
${ }^{18}$ GEPAM. Esse projeto foi desenvolvido no município de Santo André de 1998 a 2004, num convênio com a Universidade de British Columbia, financiado pela Agência Canadense de Desenvolvimento Internacional - CIDA -, cujo principal objetivo era tornar o gerenciamento municipal de mananciais em Santo André mais efetivo e participativo, atendendo às necessidades dos assentamentos informais (Luymes, 2001).
} 


\section{Divisão territorial}

Santo André localiza-se na Sub-região Sudeste da Região Metropolitana de São Paulo (RMSP). Também conhecida como Região do Grande ABC, é formada por sete municípios: Santo André, São Bernardo do Campo, São Caetano do Sul, Diadema, Mauá, Ribeirão Pires e Rio Grande da Serra, totalizando 2.529.876 habitantes segundo estimativa do IBGE (2007), em $842 \mathrm{~km}^{2}$ e Santo André, com uma área de $181 \mathrm{~km}^{2}$ (Santo André, 2008a).

Santo André conta atualmente com uma população de 654.354 habitantes, ${ }^{19}$ com densidade demográfica de 930,02 hab./km. Mais de 30.000 pessoas $^{20}$ moram em área de mananciais, sendo que a maior concentração da população está entre o Parque do Pedroso e o Braço do Rio Grande, (Represa Billings).

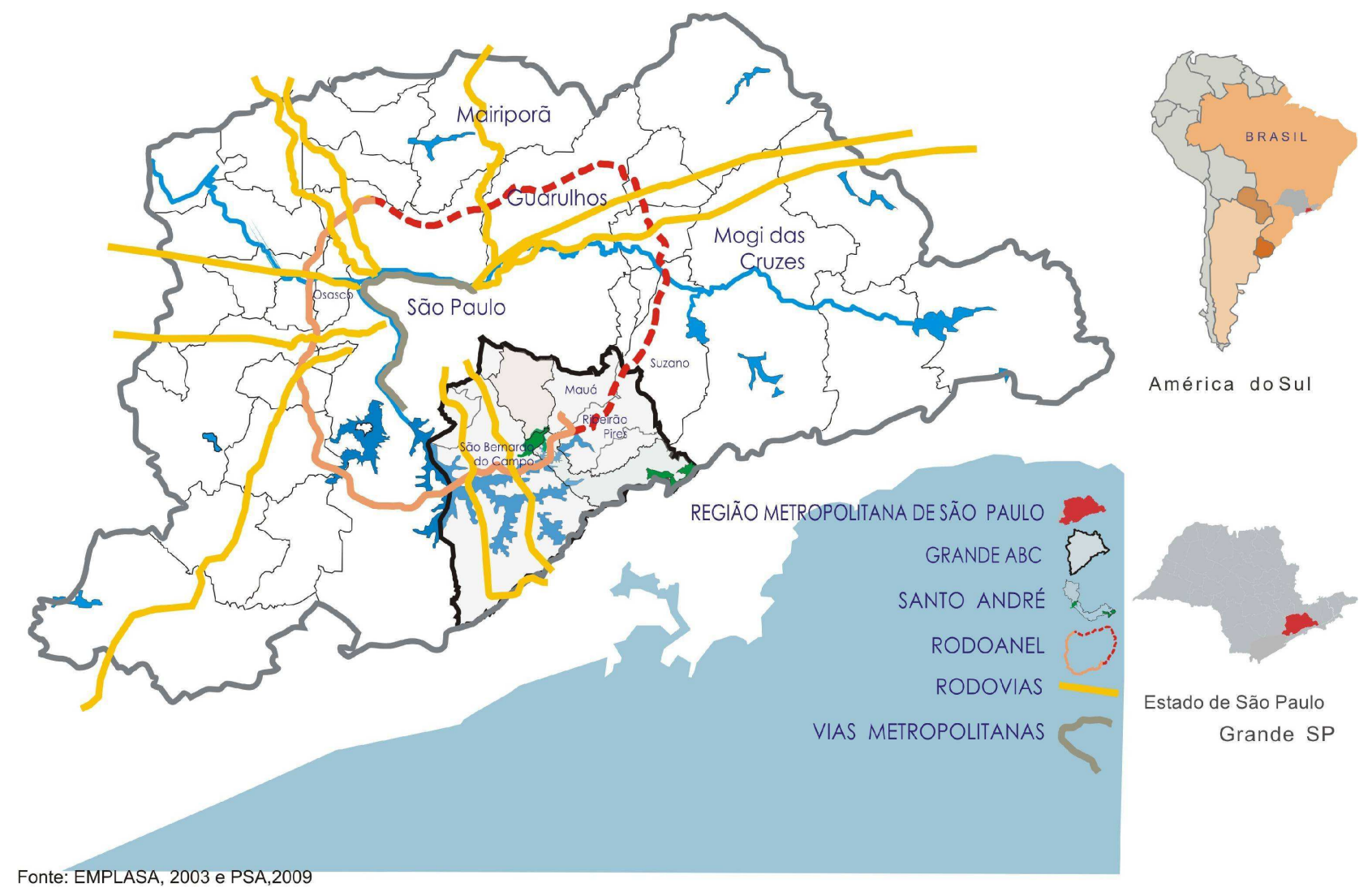

Figura 2: Localização de Santo André na Região Metropolitana de São Paulo.

${ }^{19}$ As projeções para a população de Santo André estimavam 667.891 habitantes (IBGE, 2007). Porém, os primeiros resultados do Censo de 2010 do referido Instituto, mostravam um resultado abaixo de tais projeções: 654.354 habitantes.

${ }^{20}$ Censo demográfico 2000, Ibid. 
O Plano Diretor (Lei 8.696/2004) dividiu o território do Município em duas grandes zonas: a Macrozona Urbana e a Macrozona de Proteção Ambiental. O Macrozoneamento considerou as características dos ambientes naturais e construídos com finalidade de planejamento espacial. A primeira Macrozona corresponde à área urbanizada, e a segunda às áreas de proteção ambiental e a bacia do Rio Mogi, cujos objetivos são:

"Garantir a produção de água e a proteção dos recursos naturais, recuperar as áreas ambientalmente degradadas e promover a regularização urbanística e fundiária dos assentamentos existentes e contribuir com o desenvolvimento econômico sustentável “(Lei 8.696/2004 cap.l, art.32).

O Parque do Pedroso, dentro da Macrozona de Proteção Ambiental, se enquadra na Zona de Conservação Ambiental, que objetiva promover a manutenção da qualidade ambiental e conservar os recursos naturais. O parque localiza-se no limite da delimitação das duas macrozonas, funcionando como um grande amortecimento entre a área mais urbanizada e a região de Paranapiacaba, para os Parques Municipais e Estaduais - Parque Natural Nascentes de Paranapiacaba, a Reserva Biológica Estadual e o Parque Estadual da Serra do Mar.

Uma das conecções da Macrozona urbana com essa área se faz pela estrada do Pedroso, uma estrada-parque. As outras ligações passam pelo município de São Bernardo do Campo ou por Ribeirão Pires e Rio Grande da Serra (UMAH, 2000). O Parque do Pedroso não tem todas suas divisas dentro do município de Santo André; ao sul e sudoeste faz divisa com o município de São Bernardo do Campo e com Mauá no limite nordeste, e a maior extensão com a Macrozona Urbana de Santo André. Na divisa sudeste, o trecho que margeava a represa Billings (braço do Rio Grande), ficou isolado com a implantação do Rodoanel Metropolitano.

O entorno do parque é fortemente pressionado pela ocupação urbana e o órgão gestor - SEMASA - não possui autonomia sobre a gestão de todas suas divisas, nos limites dos municípios de Mauá e São Bernardo do Campo. ${ }^{21}$

\footnotetext{
${ }^{21}$ Depoimento concedido por Cristina M. Santiago, 2009, em 04 de setembro de 2009.
} 


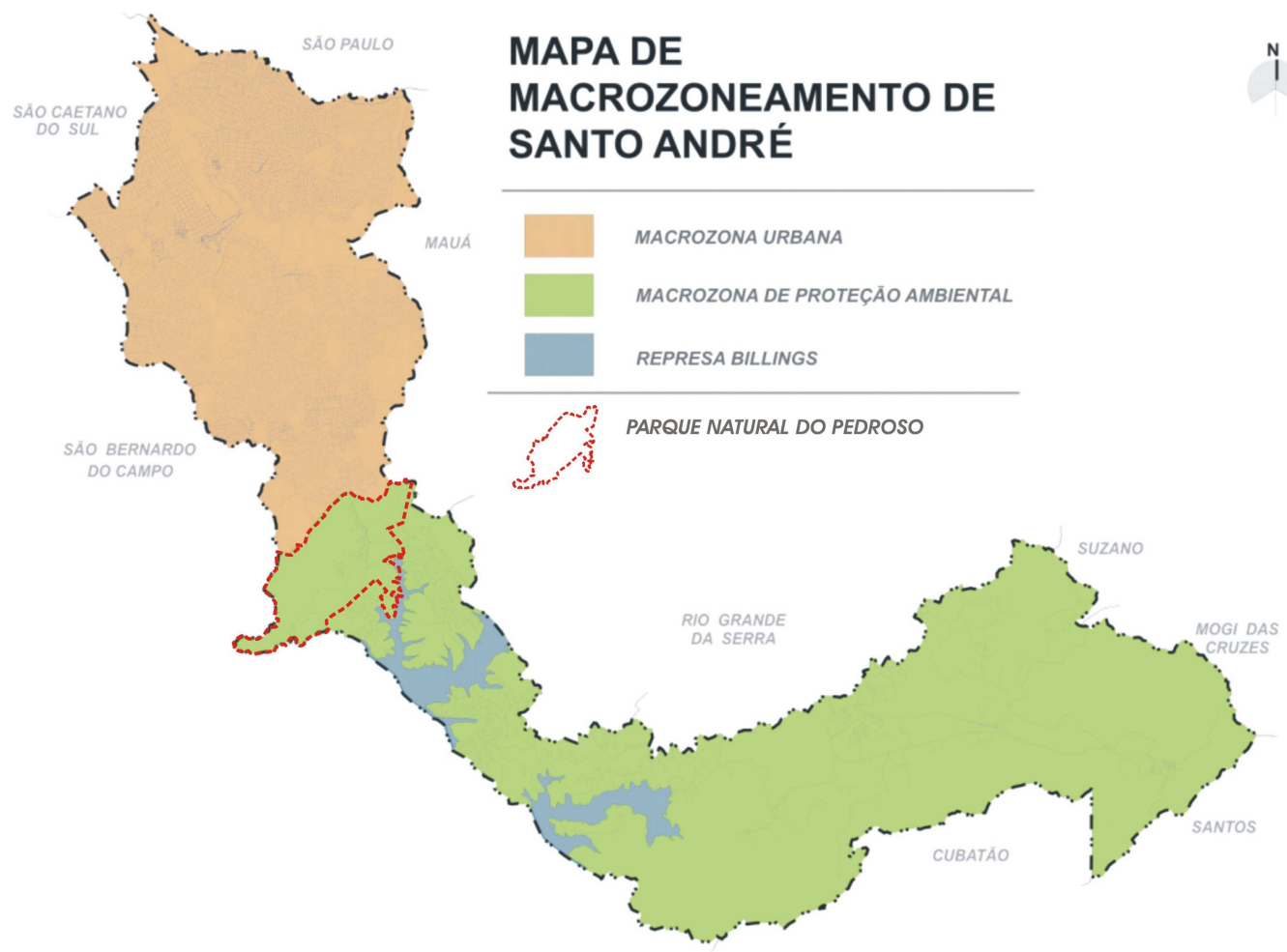

Figura 3: Macrozonas de Santo Andre de acordo com Plano Diretor (lei 8.696, de 17 de Dezembro de 2004).

Fonte: Secretaria de Desenvolvimento Urbano e Habitacão. PSA, 2004.

Todo município de Santo André localiza-se na Unidade de Gerenciamento Hídrico - UGRHI Alto Tietê -, onde estão inseridas as bacias hidrográficas do Tamanduateí, Billings e Rio Mogi, que delimitam duas "porções" distintas: a área mais urbanizada (Macrozona Urbana), localizada na bacia do Rio Tamanduateí, e a área de mananciais (Macrozona de Proteção Ambiental), na bacia Billings e Rio Mogi, responsável pelo abastecimento de água da Região Metropolitana de São Paulo. O Córrego Pedroso é um afluente da Billings, e sua sub-bacia, está totalmente dentro do Parque, possui 15 lagos, mais de 30 nascentes ${ }^{22}$ e cachoeira.

\footnotetext{
${ }^{22}$ Esses números estão sendo revistos. As nascentes foram consideradas a partir das características topográficas que constam na base oficial de planejamento - EMPLASA. Atualmente as nascentes estão sendo conferidas in loco.
} 


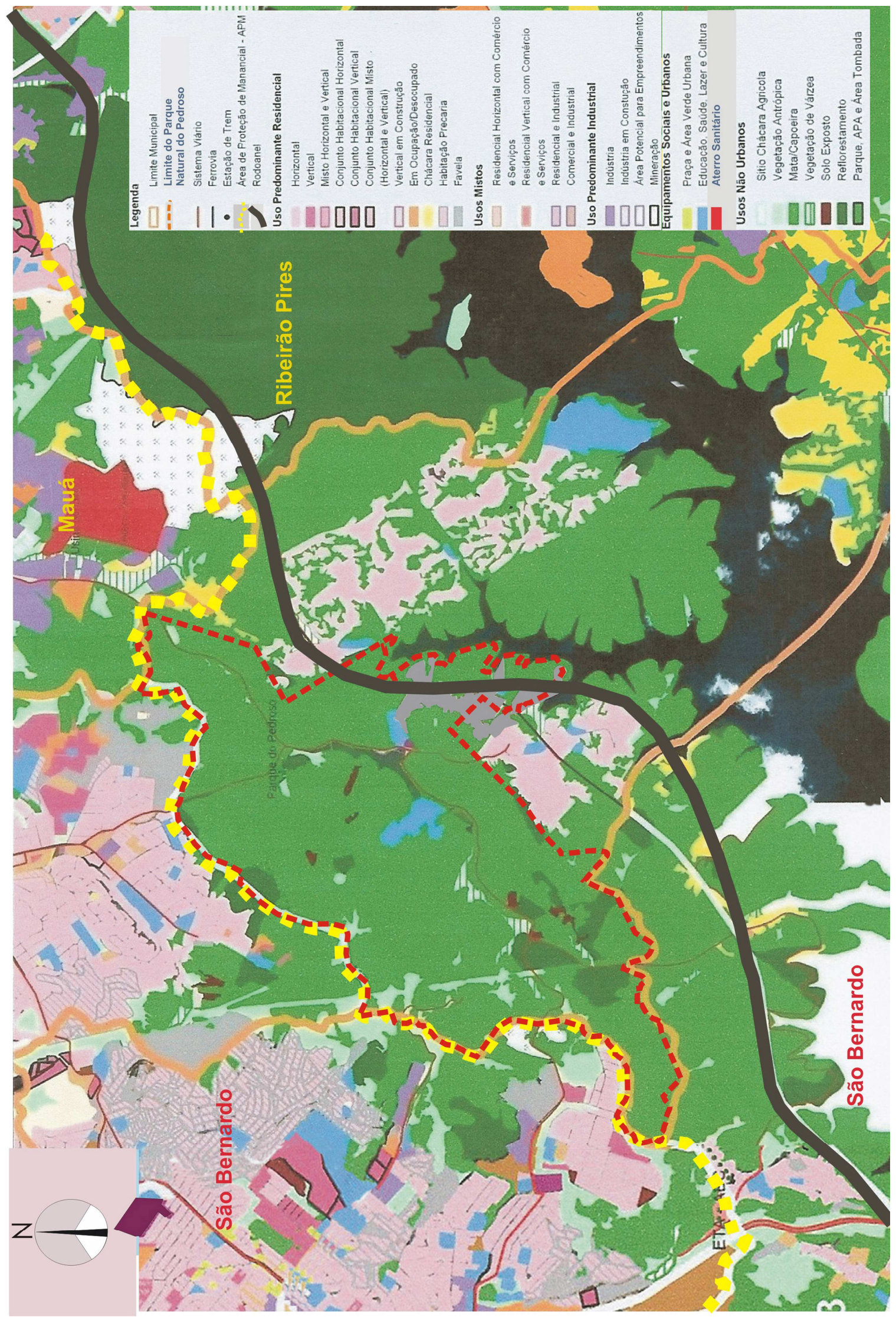

Figura 4 - Uso do solo no entorno do Parque do Pedroso. Fonte: EMPLASA, 2010, e PSA, 2009. 


\section{As águas e o parque}

Da água obtida dos poços e chafarizes públicos, transportada em pipas, sobre carroças puxadas por burros e vendida nas ruas no século XVIII, ao represamento dos rios e córregos para abastecimento da cidade, é que surge o Pedroso.

A oferta de água em abundância no início do século $X X$ foi um dos fatores que, combinado a outros atrativos, trouxeram as indústrias para a região.

O atual Parque Central, pertencia à São Paulo Railway (SPR), que utilizava as águas dessa região para garantir o abastecimento de água para as máquinas dos trens movidos a vapor da ferrovia através de uma caixa d'água instalada próxima à avenida Portugal. Essa caixa também abastecia um chafariz público, que fornecia água para o núcleo da estação. E estava instalado na Rua Luís Pinto Fláquer, entre as esquinas das ruas General Glicério e Campos Salles 'SEMASA, 2008a).

Em 26 de Outubro de 1912 era criado o "Serviço de Água e Exgottos de São Bernardo" e a primeira rede para abastecimento de água e esgotos de Santo André teve as obras iniciadas em 1911, sendo finalizadas em 1915 (Relatório, 1928).

A captação de água era feita do Ribeirão Guarará, um afluente da margem esquerda do rio Tamanduateí. As águas eram represadas por uma barragem, criando um pequeno tanque de onde eram bombeadas para um reservatório elevado de distribuição para a cidade.

Anterior às redes instaladas no Distrito de Santo André, a Vila de Paranapiacaba, na porção sudeste do município, já dispunha de um sistema de abastecimento de água implantado pelos ingleses desde o século XIX. As águas eram captadas de nascentes da Serra do Mar e transportadas para pequenos reservatórios de distribuição. Em 1892, no Alto da Serra as residências eram "construídas com as necessárias accomodações hygienicas, dotadas de canalização de água potável e de esgotos (...)" 23

Em 1916, o abastecimento de água era regular, com captação do córrego Guarará, um afluente do rio Tamanduateí, in-natura, “(...) dando logar á cor amarellada com que se apresenta a água em ocasiões de chuva". Para minimizar esse problema, havia procedimentos de decantação e a água era captada por um 
"clarificador existente junto à represa do poço da bomba contrifuga e deste pelo tubo da sucção" (Relatório, 1916:22).

Em 1919 a bomba centrífuga com motor impulsionado a vapor, foi substituída por dois motores elétricos para elevação da água ao reservatório, com a energia fornecida pela empresa Light e Power Company, contratada pela prefeitura em 1918 para esses serviços (Relatório, 1919).

O Distrito de São Caetano ainda não dispunha de rede de água e esgoto em $1921^{24}$, e a cada relatório sempre havia a demanda crescente pela ampliação das redes de abastecimento. Mas a dificuldade enfrentada pelo Distrito para a distribuição de água, no ano de 1924, apontava para uma ocupação esparsa com 10.000 (dez mil) habitantes num território de 4.000.000 $\mathrm{m}^{2}$ (quatro milhões de metros quadrados), com novos bairros de ruas longas e poucas casas, encarecendo a extensão das redes e os serviços (Relatório, 1924).

A condição sanitária em 1927 nos terrenos baixos do município, com lençóis freáticos pouco profundos que eram desprovidos de abastecimento de água e esgoto, era favorável à contaminação dos poços d'água e a saturação das fossas, que resultavam em numerosos casos de problemas intestinais e 'typho' (febre tifóide). A esse problema de saúde pública, era apresentada a necessidade de instalação de mais redes de água, esgoto e limpeza pública como uma ação sanitária (Relatório, 1927).

Em dez anos, com o crescimento da cidade, a necessidade de abastecimento de água superou a capacidade da rede instalada em 1915, que previa o atendimento de cerca de 500 casas. Em 1925, estavam ligados à rede 846 prédios $^{25}$. Estudos de projeções de crescimento da população do Relatório de 1928 apontavam para 40.000 habitantes no ano de 1950, mas era adotada uma base mais ampla, quadruplicando o número de edifícios instalados prevendo o abastecimento para 70.000 habitantes (reunindo os Distritos de Santo André e São Caetano) para aquela década. Essa estimativa foi superada: a população na região, em 1950, atingiu a casa dos 130.000 habitantes e Santo André contribuía com 80.000 (Gaiarsa, 1991).

Os estudos para alternativas de mananciais para abastecimento descreviam uma situação topográfica desfavorável nos arredores de Santo André, e a relação entre ocupação e qualidade das águas era apontada como um fator de

\footnotetext{
${ }^{23}$ Madeley-Memorial, apud Rodrigues, (1991:30).

${ }^{24}$ Relatório, 1922.

25 lbid, 1928.
} 
inviabilidade econômica diante das possíveis desapropriações necessárias e do tratamento da água. Os mananciais mais próximos da cidade atravessavam terrenos muito valorizados. Um estudo apontava para o Ribeirão Taboão e seu tributário, o Ribeirão das Pedras, com a contribuição do Ribeirão Itrapuã numa região quase despovoada, apresentando condições para captação. Foi desenvolvido um plano geral de abastecimento de Santo André e São Caetano e um projeto detalhado para a adutora Taboão em 1928, porém, não chegou a ser implantada. Havia reservatórios projetados que coincidiam com o nome dos atuais Paraíso e Gonzaga.

Embora o Ribeirão Guarará tivesse vazão suficiente para ampliação da captação, a forte ocupação do entorno já apresentava, em 1928, uma condição inadequada para o abastecimento de Santo André, apesar dos esforços em conter as ocupações e usos (captações) clandestinos feitos por moradores a montante da captação. A poluição das águas demandava medidas sanitárias, o que só veio a se efetivar em 1943, com a construção da primeira Estação de Tratamento de Água da região, a ETA - Guarará, às margens do ribeirão Guarará (foi tombada pelo patrimônio histórico municipal).

Em pouco tempo a produção de água já não era suficiente para atender a população crescente da cidade, e a necessidade voltou-se para outro manancial de águas para captação: o Ribeirão Pedroso. Em 18 de novembro de 1944, através de Decreto Municipal $n^{\circ} 73$, foram desapropriadas terras na região do Parque do Pedroso para obras de passagem da adutora de captação das águas para reforço do volume do Ribeirão Guarará.

As águas foram represadas por uma barragem de terra e um vertedor de alvenaria de pedras, formando uma bacia de 574.009 metros quadrados ${ }^{26}$, e a área que compõe o parque atual delimita toda a sub-bacia do Córrego Pedroso, afluente da represa Billings, e é responsável pelo abastecimento de aproximadamente $6 \%$ do total da água distribuída atualmente em Santo André. ${ }^{27} \mathrm{Em} 1970$ o município abandonaria definitivamente a captação das águas poluídas do Guarará.

A maior parte, $94 \%$ da água que abastece Santo André, é fornecida e comprada por atacado pelo SEMASA da SABESP - Companhia de Saneamento Básico do Estado de São Paulo -, que administra os sistemas produtores de Rio Claro e Rio Grande, entre outros.

\footnotetext{
${ }^{26}$ Processo $n^{\circ}$ 10/2007 (DPO- SEMASA, 2007).

27 Santo André, 2008a.
} 
Pela Lei Municipal $n^{0} 3.300$ de 13 de novembro de 1969, foi criado o SEMASA - Serviço Municipal de Água e Saneamento de Santo André -, resultado de uma reorganização do antigo DAE - Departamento de Água e Esgotos -, órgão da administração direta da Prefeitura criado em 1954.

O sistema Guarará compreende a estação elevatória Pedroso, localizada dentro do parque, de onde as águas são encaminhadas por meio de bombeamento até a ETA Guarará, para sua posterior distribuição para os reservatórios Miguel Ângelo, o principal na Vila Lutécia, e um segundo, na Vila Vitória, sendo este último um reservatório para substituições eventuais no caso de avarias na rede etc. A água captada do Pedroso está classificada entre 2 (dois) e 3 (três), o que significa que necessita de tratamento convencional na ocorrência da primeira classe e avançado no caso da segunda. O tratamento é em função da presença de matéria orgânica e da poluição difusa nas águas, mas o esgoto é praticamente inexistente, segundo descrição de técnicos da ETA Guarará. As águas do Pedroso abastecem a região sul da Macrozona Urbana, com 45.135 habitantes ${ }^{28}$, e a região dos mananciais é abastecida pelo reservatório da Vila Suíça, fornecida pelo Sistema Rio Claro.

\begin{tabular}{|c|c|c|c|c|c|c|}
\hline Manacial & $\begin{array}{c}\text { Responsável } \\
\text { Captação e } \\
\text { tratamento }\end{array}$ & $\begin{array}{c}\text { Local do } \\
\text { Manancial }\end{array}$ & $\begin{array}{c}\text { Local da } \\
\text { ETA }\end{array}$ & Município & $\begin{array}{c}\text { Volume } \\
\text { (milhões } \\
\text { litros/dia) }\end{array}$ & (\%) \\
\hline $\begin{array}{c}\text { Sistema } \\
\text { Rio Claro }\end{array}$ & SABESP & $\begin{array}{c}\text { Represa } \\
\text { Ribeirão do } \\
\text { Campo }\end{array}$ & $\begin{array}{c}\text { ETA } \\
\text { Casa } \\
\text { Grande }\end{array}$ & $\begin{array}{c}\text { Biritiba } \\
\text { Mirim }\end{array}$ & 115,2 & 68,9 \\
\hline $\begin{array}{c}\text { Sistema } \\
\text { Rio } \\
\text { Grande }\end{array}$ & SABESP & $\begin{array}{c}\text { Represa } \\
\text { Billings }\end{array}$ & $\begin{array}{c}\text { ETA } \\
\text { Riacho } \\
\text { Grande }\end{array}$ & $\begin{array}{c}\text { São } \\
\text { Bernardo } \\
\text { do Campo }\end{array}$ & 41,8 & 25,0 \\
\hline $\begin{array}{l}\text { Sistema } \\
\text { Pedroso }\end{array}$ & SEMASA & $\begin{array}{c}\text { Parque do } \\
\text { Pedroso }\end{array}$ & $\begin{array}{c}\text { ETA } \\
\text { Guarará }\end{array}$ & $\begin{array}{c}\text { Santo } \\
\text { André }\end{array}$ & $\mathbf{1 0 , 2}$ & $\mathbf{6 , 1}$ \\
\hline Total & \multicolumn{7}{|l|}{} & $\mathbf{1 6 7 , 2}$ & $\mathbf{1 0 0}$ \\
\hline
\end{tabular}

Tabela 3: Mananciais Responsáveis pelo Abastecimento de Água em Santo André. Fonte: SEMASA 2008.

Pela Lei $n^{0} 7.733$, de 14 de outubro de 1998, na gestão do então Prefeito Municipal Celso Augusto Daniel, ${ }^{29}$ estabeleceu-se a Política Municipal de Gestão e Saneamento Ambiental, e em 1999, o SEMASA, como órgão técnico e executor dessa política, tornou-se a primeira organização do país a integrar todas as dimensões do saneamento, como a distribuição de água; coleta e afastamento de

${ }^{28}$ Censo de 2000 , IBGE.

29 In memorian. Mandato de 1997 a 2000. 
esgotos, drenagem urbana, gestão ambiental, gestão de resíduos sólidos e a gestão de riscos ambientais - Defesa civil $^{30}$. Esses setores de gestão foram incorporados ao SEMASA, paulatinamente, nessa respectiva ordem aqui colocada.

O empreendimento que marcou profundamente a cidade e a região foi a construção do reservatório Alto da Serra (mais tarde renomeado como Billings), na década de 1930. Fazia parte de um complexo sistema hidráulico que, por meio de bombeamento das águas do Rio Tietê e Pinheiros, era utilizado para aumentar a vazão do reservatório e ter suas águas lançadas em um desnível de mais de setecentos metros até a usina hidrelétrica de Henry Borden em Cubatão, objetivando a produção de energia elétrica para a região. A captação de água potável para consumo nesse reservatório só foi iniciada em 1958.

As contradições em se bombear águas extremamente poluídas, utilizando o reservatório para abastecimento de água potável, somente foram enfrentadas na década de 1990, com a proibição do bombeamento, permitido apenas para o controle de enchentes. No entanto, na década de 1970, cresceu a preocupação do Estado com a qualidade das áreas produtoras de água para abastecimento, diante da forte expansão urbana. Em decorrência disso, em 1975 foi sancionada a Lei Estadual de Proteção dos Mananciais ( $n^{\text {os }} 898 / 75$ e 1.172/76) com o objetivo de proteger a integridade e qualidade da água nesses reservatórios, estabelecendo parâmetros (limites) para uso do solo nas áreas de mananciais.

Essa legislação mostrou-se rígida, porém sem respaldo governamental e apoio da sociedade para sua completa implementação, não criando instrumentos que viessem controlar a pressão da enorme expansão urbana e a ocupação informal das áreas dos mananciais. Na década de 1990, ocorreu um forte adensamento populacional na bacia da Billings, inicialmente por loteamentos formais e depois loteamentos irregulares e assentamentos precários, em sua maioria favelas. Esses últimos têm como característica a ausência de infraestrutura sanitária básica, são construídos em áreas de encostas erodíveis, em barracos e diretamente nas bordas dos reservatórios. Como consequência, ocorre o assoreamento e poluição da água por água servida e esgoto. A vegetação suprimida expõe o solo a problemas de erosão e de degradação do habitat (Luymes, 2001).

Reconhecendo esse quadro de degradação nas áreas de mananciais, o governo estadual aprovou a lei no 9.866/1997, que estabeleceu as áreas de

\footnotetext{
${ }^{30}$ SEMASA, 2006.
} 
Proteção e Recuperação de Mananciais - APRM - e atestava a necessidade de dar atenção especial para algumas áreas localizadas, em decorrência do intenso processo de degradação, criando novas formas de gestão de bacias hidrográficas (comitês e subcomitês de bacias), vislumbrando parcerias com as prefeituras na gestão e na elaboração de novas normas de uso e ocupação do solo. Estabeleceuse também a necessidade de elaboração de Planos de Desenvolvimento e Proteção Ambiental - PDPA -, assim como leis específicas para cada bacia. ${ }^{31}$

Bacias hidrográficas são definidas pelo relevo, tendo como divisores de águas os terrenos mais elevados. O rio principal nomeia a bacia e recebe a contribuição de afluentes, cada um com tributos menores. As divisões políticoadministrativas são alheias às bacias hidrográficas, que determinam processos naturais, mas com a Lei $n^{\circ}$ 9.433/1997 regulamentou-se a nova política de recursos hídricos e ordenamento territorial, organizando o sistema de gestão por bacias hidrográficas.

\footnotetext{
${ }^{31}$ Em 16 de janeiro de 2006 foi aprovada a Lei Estadual $n^{\circ}$ 12.233: a Lei Específica da Área de Proteção e Recuperação dos Mananciais do Guarapiranga - APRM-G.

Em 13 de julho de 2009, foi sancionada a Lei específica da Billings, Lei $n^{0} 13.579$, que define a Área de Proteção e Recuperação de Mananciais da Bacia Hidrográfica do Reservatório Billings - APRM-B. Ambas as áreas estão situadas na unidade de gerenciamento dos recursos Hídricos do Alto Tiête e são mananciais de interesse regional para abastecimento da população atual e futura. Essas leis dispõem sobre diretrizes e parâmetros para uso e ocupação do solo.
} 


\section{Parque do Pedroso: nascido das águas}

A proteção em torno das nascentes, visando o abastecimento de água do município, foi o princípio da formação do parque atual. A necessidade de garantir um manancial de água potável em melhores condições para consumo fez com que as primeiras terras em torno da captação fossem preservadas.

O Parque do Pedroso teve início no ano de 1944 através do decreto Municipal $\mathrm{n}^{\circ} 73$, quando uma soma de glebas com área de 547.009,00 $\mathrm{m}^{2}$ foram desapropriadas e declaradas de utilidade pública para as obras de captação e passagem da linha adutora das águas do Ribeirão Pedroso (para encaminhá-las à estação de tratamento do Guarará). Essa área só seria constituída oficialmente como uma Reserva Florestal em $1955^{32}$, quando houve uma nova desapropriação para proteção das águas do Ribeirão Pedroso, e contribuintes, descrevendo uma área de 4.350.000,00 $\mathrm{m}^{2}$ e incluindo a linha de transmissão da Light dentro dessa descrição do terreno (um dos confrontantes era o divisor entre as bacias do Ribeirão Pedroso e do Ribeirão Guarará).

A constituição oficial de uma reserva florestal (e mais tarde de um parque), foi observada como um fato avançado para época, tendo um município como patrocinador desta proteção. As iniciativas de conservação de áreas florestais se originavam nas esferas Estaduais e Federal, e só posteriormente eram aplicadas pelos municípios. A criação de parques foi mais intensa na década de 1970 e no caso do Pedroso, segundo depoimento de Cristina M. Santiago (op.cit.), houve um pioneirismo na história da conservação do Brasil.

A descrição dos limites do parque no Decreto $n^{\circ}$ 9.709, de março de 1979, que deu origem à lei sobre a mudança de denominação - de Horto Municipal do Pedroso para Parque Regional e Jardim Botânico do Pedroso - descreve um imóvel "situado na Zona Rural, delimitado pelas divisas com os Municípios de São Bernardo do Campo e de Mauá, Represa Billings, Córrego Guararazinho, Estrada Cata Preta e loteamentos confinantes" (sem grifo no original).

A unidade de conservação foi instituída pela lei Municipal 7.733, de 14 de outubro de 1998, definindo-o como Parque Natural Municipal e posteriormente enquadrando-o na categoria de unidades de conservação de proteção integral, de acordo com a Lei Federal no 9.985, de 18 de julho de 2000, o SNUC - Sistema Nacional de Unidades de Conservação. O Parque Regional e Jardim Botânico do 
Pedroso passou a denominar-se Parque Natural Municipal pela Lei Municipal $n^{\circ}$ 8.881/2006.

O Parque do Pedroso possui cerca de $8,39 \mathrm{Km}^{2}$ localizados no município de Santo André, dentro da região metropolitana de São Paulo-RMSP, equivalente ao maior Parque municipal da cidade de São Paulo ${ }^{33}$.

Esse número, atualmente, já foi alterado pela recente secção criada no parque com a implantação do Rodoanel Metropolitano Mário Covas, que estabeleceu um isolamento entre trechos de mata que antes estavam conectados, criando uma barreira e formando mais fragmentos isolados, cuja área prevista era de 138.849,60 $\mathrm{m}^{2}$ em zonas desafetadas do parque. ${ }^{34}$ Áreas invadidas, como as favelas Pintassilgo e

Toledana, foram retiradas do parque através de um cercamento, um dos ítens de compensação pelos danos ambientais causados pela implantação da rodovia.

O nome Pedroso teve origem nos antigos proprietários das terras no final do século XIX, a família Pedroso, de nacionalidade brasileira. Atualmente, o Parque do Pedroso corresponde à maior reserva natural do Grande ABC "com paisagem predominante de Mata Atlântica" (Santo André, 2008a:197).

Dentro do município de Santo André há outros parques, que se enquadram no SNUC, como a unidade de conservação de Proteção Integral Parque Natural Nascentes de Paranapiacaba com 4,26 $\mathrm{Km}^{2}$, a Unidade de Conservação de Uso Sustentável (APA) Haras São Bernardo, com 0,3409 km² (34,09 ha), a Reserva Biológica Estadual do Alto da Serra de Paranapiacaba, com $3,36 \mathrm{~km}^{2}$ e o Parque Estadual da Serra do Mar, com 2,65 $\mathrm{km}^{2}$ dentro do município de Santo André, atravessa vinte e oito municípios e é considerado Reserva da Biosfera pela UNESCO. O Parque Estadual da Serra do Mar é a maior extensão contínua preservada de Mata Atlântica. Há também nove parques urbanos (Santo André, 2008b).

\footnotetext{
32 Santo André. Decreto n ${ }^{\circ}$ 922, de 19 de fevereiro de 1955.

${ }^{33}$ Depoimento concedido por Raul I. Pereira em 05 de junho de 2009. Parque Anhanguera, o maior Parque Municipal de São Paulo, com $9,00 \mathrm{~km}^{2}$ (900 ha).

${ }^{34}$ SEMASA, Santo André, 2007.
} 


\section{Parque Regional e Jardim Botânico do Pedroso}

Uma verba reservada em 1973 para desapropriações, projeto e execução do Parque Florestal do Reservatório do Pedroso (Horto Municipal do Pedroso) foi autorizada por meio da Lei $n^{\circ} 4.167$.

Com a denominação de Parque Regional e Jardim Botânico do Pedroso, essa região ficou definida como área ecológica, em 1991, ${ }^{35}$ sendo a Guarda Municipal responsável por sua fiscalização e preservação, juntamente com as áreas verdes de dentro do Distrito de Paranapiacaba, da chácara Pignatari, do Parque Regional da Criança Palhaço Estrimilique e do Parque Regional Duque de Caxias (atual Parque Prefeito Celso Daniel), que eram consideradas áreas fundamentais para manutenção do ecossistema local.

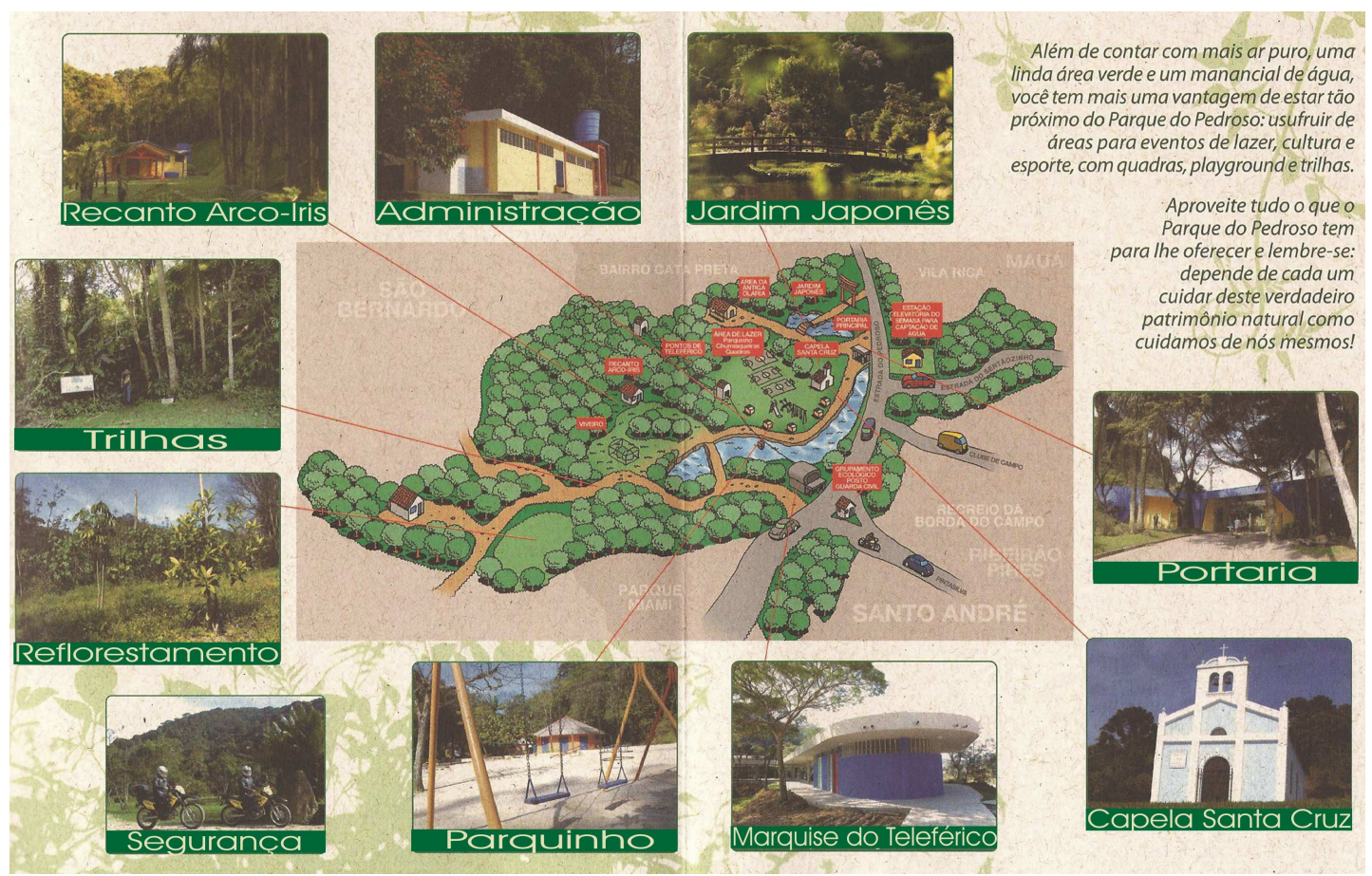

Figura 5. Folder informativo.

Fonte: SEMASA, PSA [2005?]

\footnotetext{
${ }^{35}$ Lei Orgânica Municipal, emenda nº4, de 02 de abril de 1991.
} 
Uma estrutura voltada para o lazer foi instalada início da década de 1970 em uma área de quatorze alqueires, com dois campos de futebol, quadra de basquete, vôlei, bocha e malha. A água de diversas nascentes que brotavam dos barracos foram reservadas e utilizadas nos vestiários, sanitários e bebedouros. Um grande número de frequentadores utilizava as churrasqueiras, os quiosques, lanchonete e um pequeno palco para dança (Diário, 1999).

Segundo depoimento de Maria e Miguel Pastor, ${ }^{36}$ o parque contava ainda com cerca de trinta e dois funcionários, primeiros socorros em uma enfermaria, um motorista e veículo para eventualidades, bombeiros aos domingos, e equipamentos de lazer, como minizoológico, áreas para piquenique, playground, casa do Tarzan (em frente à bica d'água), pedalinho e teleférico. De uma estação de embarque, saíam os pedalinhos para uma volta de meia hora até a barragem do viveiro.

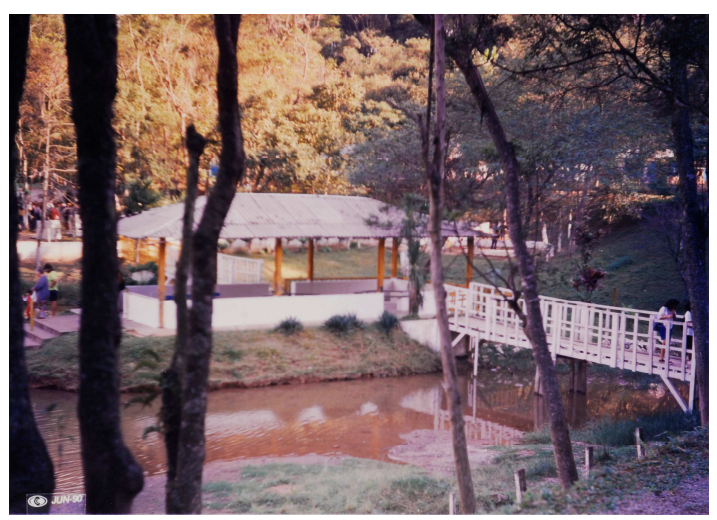

2. Antiga saída do pedalinho. Fonte: Acervo MSAOAG, 1990.

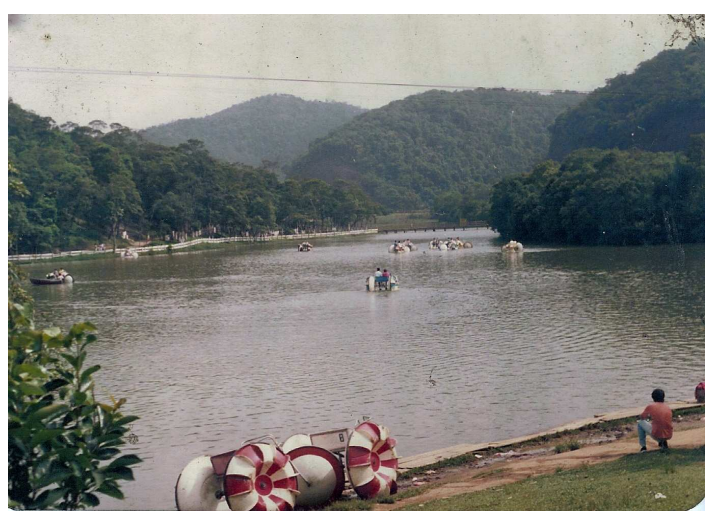

3. Lago com pedalinhos. Fonte: Maria e Miguel Pastor, [198-].

Os viveiros de animais foram implantados na mesma época da instalação do teleférico, entre 1977 e 1978, com animais como: macacos, onça pintada, jaguatirica, javali, gavião, arara-azul, jacu, porco-espinho, cateto, animais trazidos e soltos pelo parque como patos, bando de paturis na represa e perus. Os viveiros de pássaros onde "tinha de tudo" (contava com galinha d'angola, passarinhos, canarinhos), era "uma tela passada" em frente ao parquinho infantil, abaixo da grande cobertura, segundo o depoimento.

\footnotetext{
${ }^{36}$ Depoimento concedido por D. Maria e Sr. Miguel Pastor, em 13 de maio de 2009.
} 


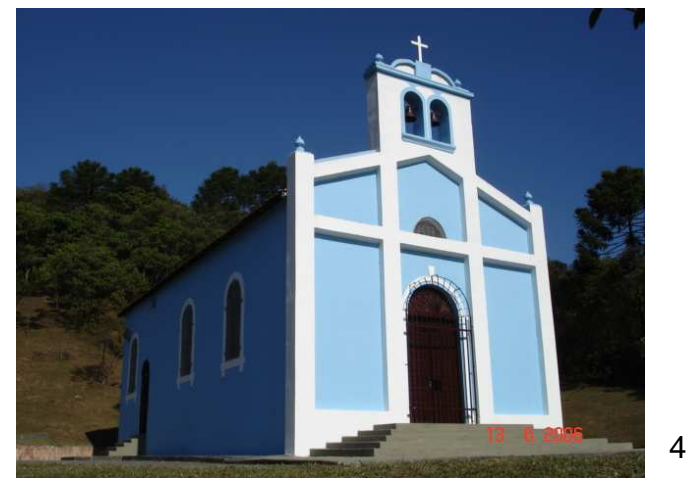

Um dos atrativos do parque instalado em 1976 é uma réplica de uma antiga capela, originalmente localizada na esquina da Avenida Santos Dumont e Avenida D. Pedro I, no centro de Santo André, que foi demolida para dar lugar à Avenida Perimetral.

A Capela de Santa Cruz dos Carvoeiros foi reconstruída numa privilegiada implantação dentro do Parque do Pedroso, e atualmente, nela, são realizadas celebrações periódicas. Na capela original reuniam-se viajantes, lenhadores e moradores da zona rural; era conhecida como Capela dos Carvoeiros por ficar no início do caminho que ligava o Caminho do Pilar às áreas de extração de carvão no final do século XIX (Religiões, 2008).

$\mathrm{Na}$ esquina do Tanque dos Turcos $^{37}$ foi construída a grande atração do parque: a primeira estação de embarque do teleférico, também chamada de primeira torre, formando um conjunto com uma marquise modernista em concreto armado, onde funcionava um bar, bilheterias e sanitários. Foi um projeto de 1977, desenvolvido pelo Arquiteto Rui Ohtake com três estações. Era o mais longo e moderno da América Latina, com uma extensão de 1.600 metros e desnível de 260 metros, possuía 37 cabines, cada uma com capacidade para transportar até seis pessoas (Diário, 1985).

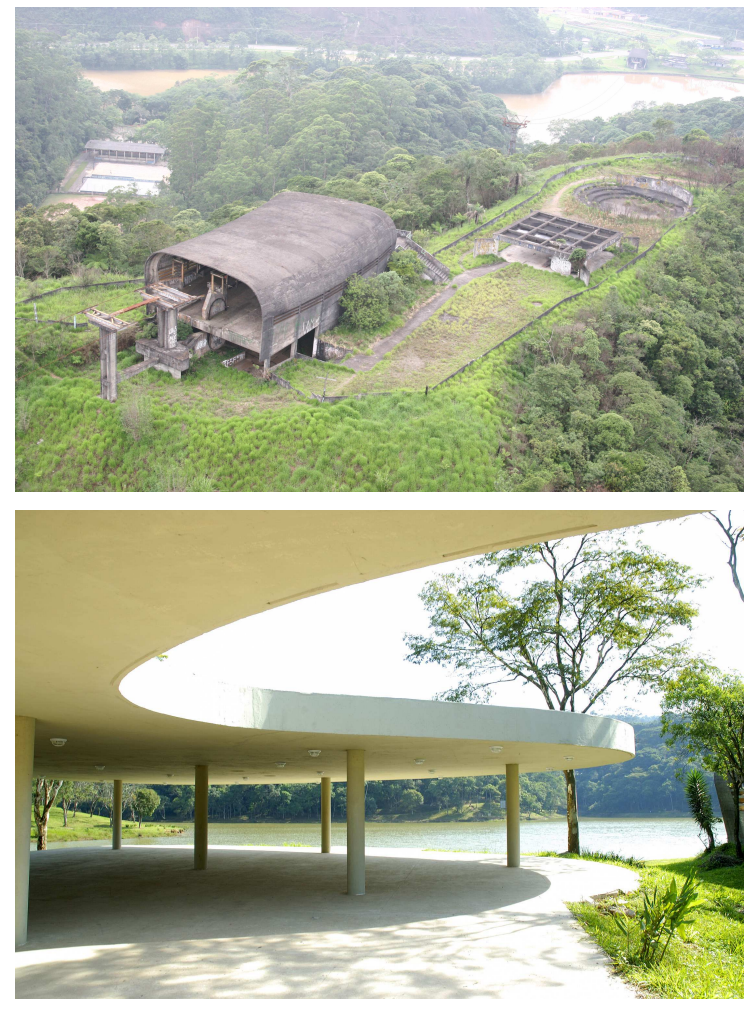

5. Estação $B$ ou $2^{u}$ torre do teleférico. Ao fundo, lago e quadras de esportes. Fonte: DGA, SEMASA. 2006

6. Marquise do teleférico e lago ao fundo. Fonte: CCS, SEMASA. 2008.

\footnotetext{
${ }^{37}$ A Represa do Pedroso era chamada de Tanque dos Turcos no final da década de 1960, segundo Médici (op. cit.). Essa denominação também foi mencionada do depoimento de D. Maria e Sr.Miguel Pastor (op. cit.).
} 


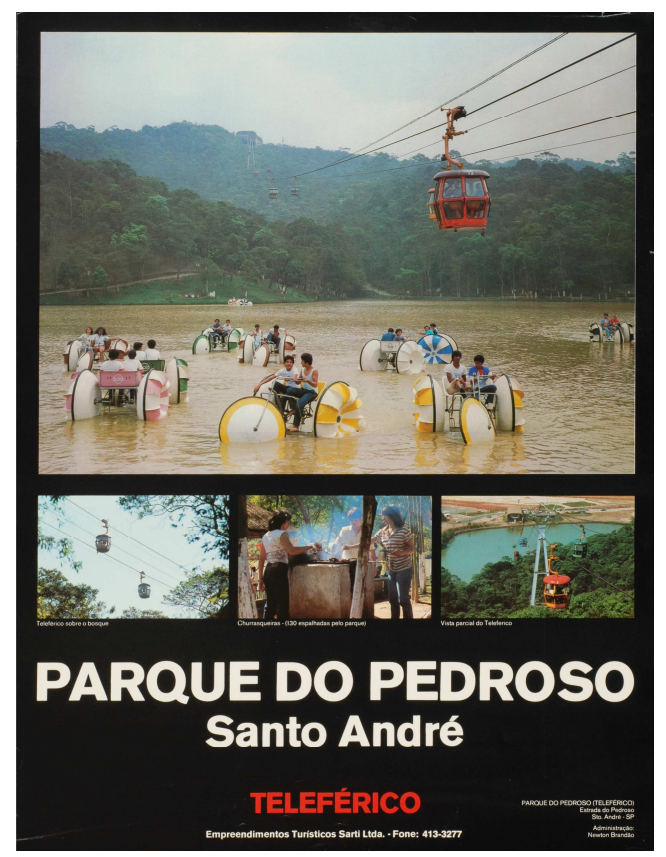

7. Folder. Fonte: Acervo MSAOAG, s.d.

"Uma viagem pelo teleférico proporciona visões fantásticas de uma área verde de paisagens que muitos poderiam não acreditar que existissem numa região industrializada como a do Grande ABC. No teleférico, com toda segurança, o visitante sentirá a emoção das alturas, descobrirá plantações agrícolas caseiras e, da estação final, terá condições de avistar todo o grande $A B C$ e parte da Capital. No alto do teleférico fica o Restaurante Panorâmico, especializado em comida típica mineira" (Diário, 1985).

A época de instalação e operação do teleférico do Pedroso aconteceu num período em que era comum também em outras cidades esse equipamento de lazer, assim como foram as fontes luminosas. ${ }^{38} \mathrm{O}$ maquinário do teleférico era de fabricação italiana, operado do final da década de 1980 a 1992 por um mesmo concessionário do teleférico de Poços de Caldas. ${ }^{39}$

O desencadear da decadência do parque de lazer, esteve associado ao fechamento do teleférico no ano de 1992. O alto custo de manutenção e operação somado à mudança da região com o crescimento das ocupações irregulares no entorno, gerou na década de 1990 um parque estigmatizado: “(...) é lugar de baixa renda (...) é perigoso para ir", "é tido como uma coisa do 'povão lá do fundo', um lugar que os moradores do centro não vão visitar (...), ali é uma passagem para quem vai para o Parque Miami ou para outros lugares, e quem frequenta o parque são os moradores do entorno". 40

O teleférico entrou em obsolescência e "quando acabou, a administração permitiu (...) tudo foi roubado". 41

\footnotetext{
${ }^{38}$ Depoimento Raul I. Pereira, op. cit..

39 Depoimento concedido por Luis H. R. Zanetta em 20 de junho de 2010.

${ }^{40}$ Depoimento Raul I. Pereira, op. cit.

${ }^{41}$ Depoimento D. Maria e Sr.Miguel Pastor, op. cit.
} 
Em 2005, através de um Grupo Gestor do Parque, com representação exclusiva do poder público-Secretaria de Governo, de Educação; Cultura, Esportes e Lazer, Desenvolvimento Urbano e Habitação e Secretaria de Obras sob a coordenação do SEMASA, iniciam-se as discussões sobre as demandas gerais de melhorias na infraestrutura, segurança, acessibilidade, incrementação das atividades de esportes e lazer e busca de soluções para os conflitos existentes. $O$ objetivo desse grupo era buscar uma gestão compartilhada, cumprindo parcialmente o que dispõe o SNUC em seu artigo 29 sobre o Conselho Consultivo de unidades de conservação de Proteção Integral, que além da representação do órgão responsável por sua administração, do órgão público, prevê a participação da sociedade civil.

Uma das diretivas do Grupo Gestor foi a revitalização da área de lazer, que iniciou-se com intervenções emergenciais, como pinturas, reforma na portaria e nos sanitários. E, em 2007, efetivamente foi desenvolvido um projeto para a área de lazer de uso intensivo, com aproximadamente $170.000 \mathrm{~m}^{2}$ (Lavendowisk, et.al., 2006).

Era uma demanda requisitada pela população em orçamento participativo, e foi com a participação da comunidade, através de oficinas, que se alcançou um projeto que pretendia atender às necessidades de uso para o lazer e, ao mesmo tempo, ser compatível com uma unidade de conservação. Os participantes foram dos bairros: Recreio da Borda do Campo, Jardim Clube de Campo, Jardim Santo André, Núcleo Pintassilgo, Sacadura Cabral, Vila Luzita, Parque João Ramalho, Jardim Aclimação e Sítio dos Vianas. As oficinas foram realizadas dentro do próprio parque, e houve ainda algumas apresentações para os funcionários do SEMASA, da Prefeitura e para o público em geral no Seminário do mês do Meio Ambiente.

O projeto foi desenvolvido não avançando em áreas ocupadas por mata, requalificando os espaços que estavam mal resolvidos e inadequados e recuperando as construções de Ruy Ohtake, atualizando os usos. Com um programa extenso, esse projeto previa a execução de edifícios novos (mirantes e guaritas), a requalificação dos edifícios existentes, criando um Centro de Visitantes no edifício do teleférico (marquise) - que não foram executados -, uma ciclovia, criando um circuito, o uso recreativo da água e a requalificação dos chafarizes, bicas d'água e quiosques, criando cascatas próximas das quadras, campos de 


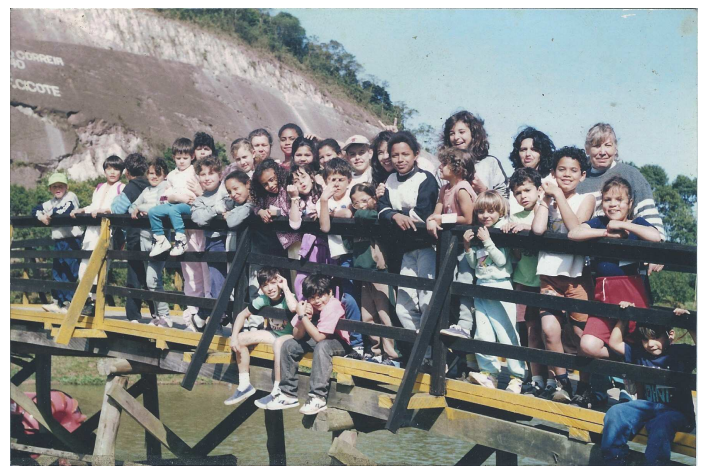

8. Usuários do parque na Ponte. Fonte: Maria e Miguel Pastor. [198-]

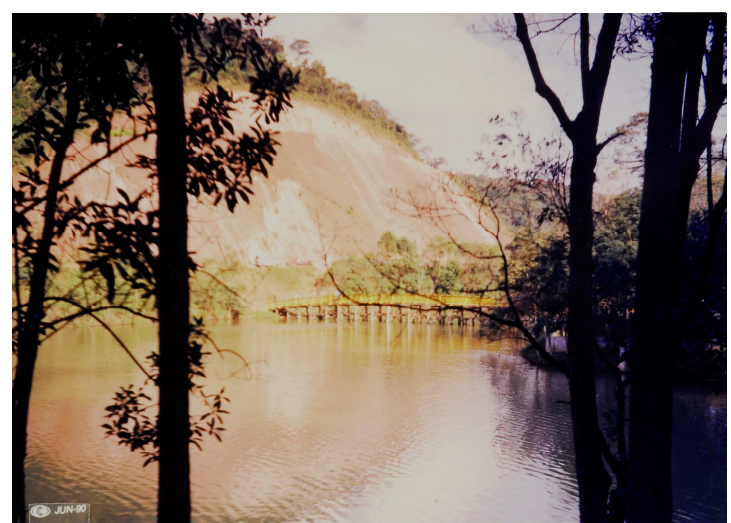

10.Antiga ponte de madeira.

Fonte: MSAOAG. 1990.

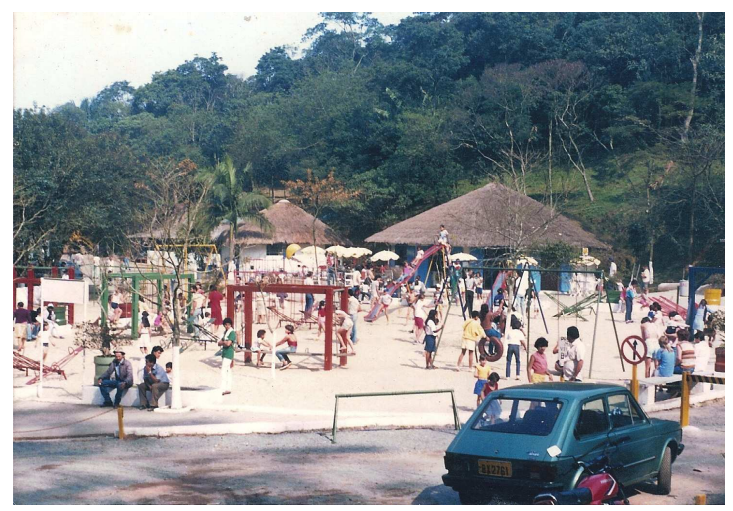

12. Parque infantil.

Fonte: Maria e Miguel Pastor. [198-]

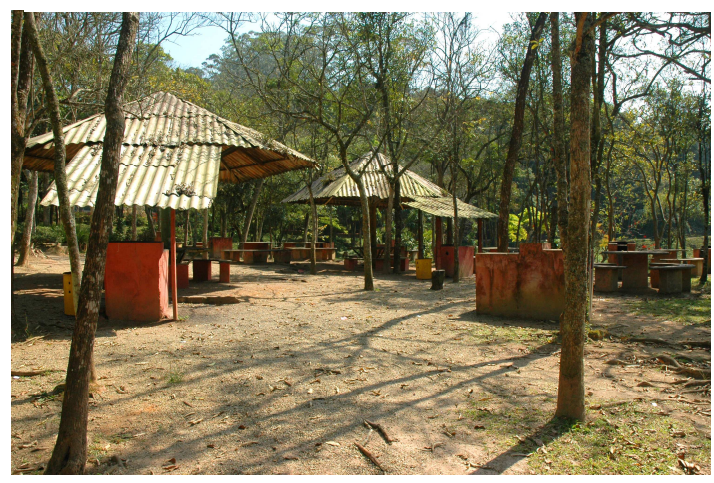

14. Área de quiosques e churrasqueiras. Fonte: DGA/SEMASA. 2005.

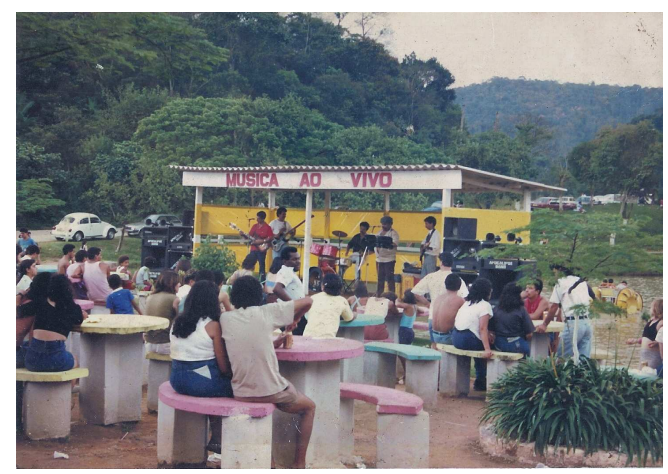

9. Música ao vivo, ao lado da marquise do teleférico. Fonte: Maria e Miguel Pastor.[198-]

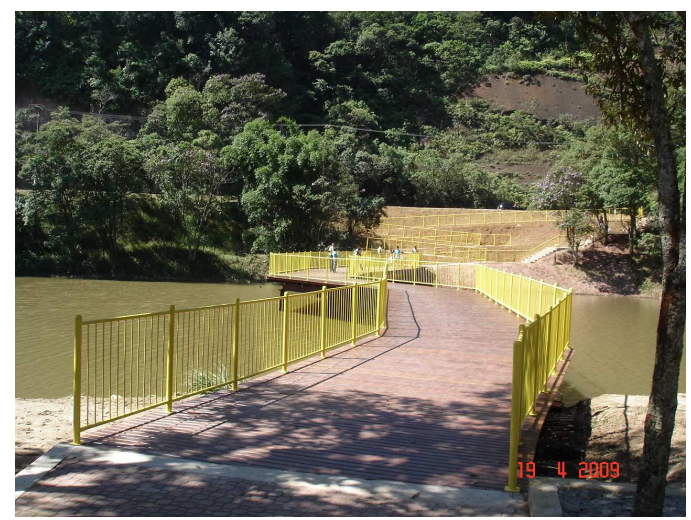

11. Nova ponte, no mesmo local da antiga. Fonte: DGA / SEMASA. 2009.

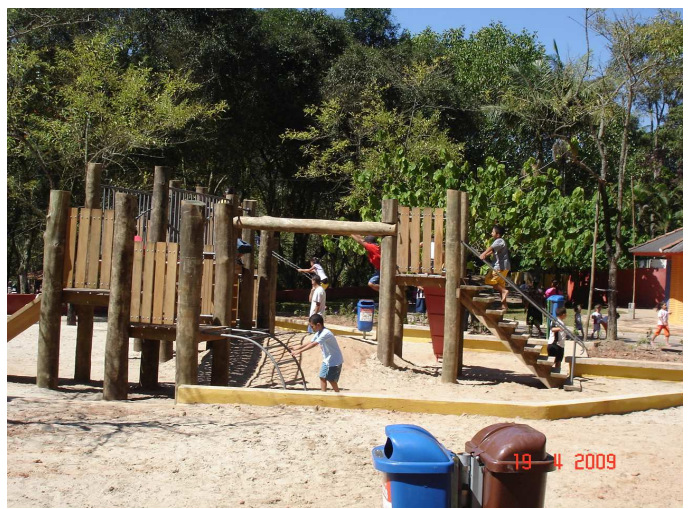

13. Novo parque infantil, implantado parcialmente. Fonte: DGA/SEMASA, 2009.

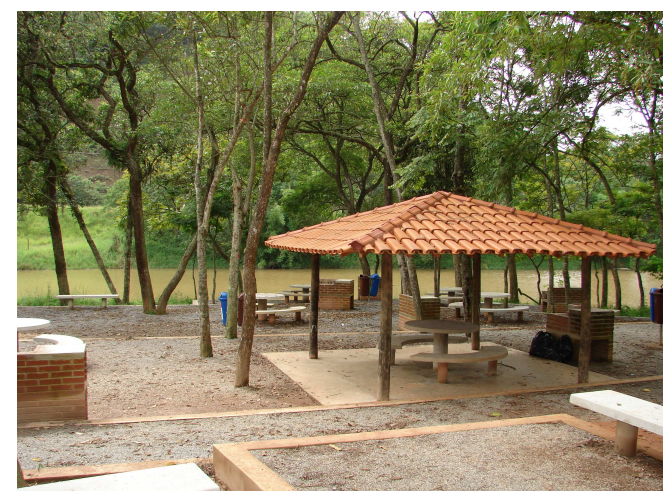

15. Área de quiosques e churrasqueiras reformada. Fonte: DGA/SEMASA, 2009. 
de futebol e do parque infantil principal.

A obra de revitalização iniciada em 2008 foi implantada parcialmente, com várias alterações no projeto por razões que compreenderam desde o orçamento disponibilizado para sua implantação até alterações no programa, entre elas: a retirada do estacionamento para veículos de passeio (interno ao parque) e as alterações das atividades esportivas no Jardim Japonês e em frente aos vestiários. Basicamente, manteve-se do projeto original o zoneamento das atividades. A implantação compreendeu as áreas das churrasqueiras, a ponte, o circuito interno da ciclovia, a quadra de futebol do Jardim Japonês, quadras de areia em frente aos vestiários, os parquinhos infantis e o paisagismo que envolvia as áreas reformadas.

Durante a atividade do Grupo Gestor, foi desenvolvido diagnóstico e zoneamento preliminares, visando o plano de manejo, quando foram elencados os seguintes conflitos no parque:

1. O chamado "Santuário Ecológico da Serra do Mar", o Santuário Nacional de Umbanda, com endereço na Estrada do Montanhão, $n^{\circ} 700$, de responsabilidade da Federação Umbandista do Grande ABC - FUGABC -, ocupa uma área de $640.462,50 \mathrm{~m}^{2}$ dentro dos limites do parque. Utilizado para práticas religiosas do segmento religioso da umbanda, foi autorizado em 1979, na Gestão do então prefeito Lincoln Grillo, como uma concessão de direito real de uso público, renovada e estendida pelo prazo de 20 anos em 2008 (Projeto de Lei no 43/08), ainda permitindo a arrecadação de uma taxa de manutenção para manter a área em "perfeito estado de limpeza e conservação".

O Santuário Nacional da Umbanda tem uma visitação pública de 800 a 1.200 pessoas por semana (concentrada em finais de semana). Existem no local mais de 300 tendas e outros equipamentos de suporte, como edifício da administração, portal de entrada, sanitários, lanchonete e minhocário. (Santiago, 2003)

Com a concessão de 1979, o que era posse de fato passou a ser de direito $^{42}$. Um pequeno grupo religioso motivado pelos atributos naturais da área, já utilizava o fundo de vale, quando a Pedreira Montanhão ainda estava em atividade (com uma detonação por dia), aproximadamente no ano de 1955.

\footnotetext{
42 Depoimento concedido por Ronaldo Antonio Linares, em 23 de junho de 2009.
} 


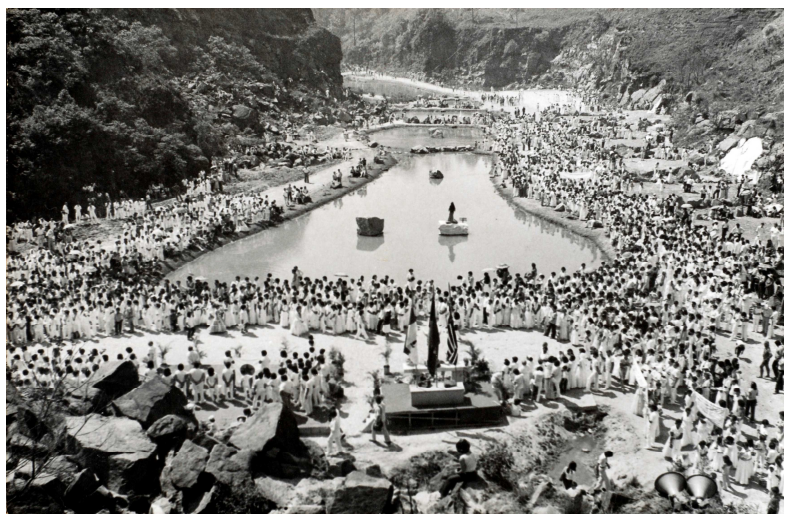

16. Inauguração do Santuário Nacional de Umbanda, no final da década de 1970. Fonte: acervo MSAOAG, déc. 70 .

Segundo Relatório da FUGABC (2005), a inauguração oficial foi em 20 de setembro de 1981.

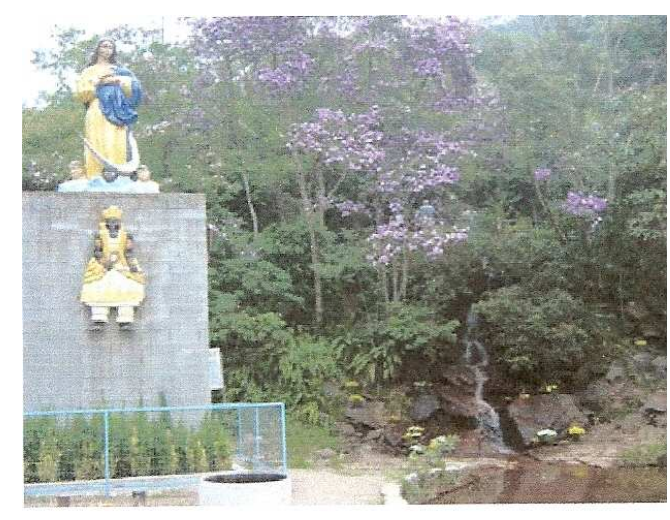

17. Santuário. Imagens e cachoeira ao fundo. Fonte: FUGABC, 2005.

A Mata Atlântica dessa região foi explorada para obtenção da madeira de lei visando a produção de móveis, para usos mais nobres, e, outras, para lenha e produção de carvão, como já vimos. Houve a tentativa de reflorestamento com o Eucalipto, uma espécie exótica de rápido desenvolvimento, que ainda hoje é encontrada em várias outras áreas do parque.

O plantio foi abandonado pela dificuldade que ofereciam as encostas muito íngremes do morro. O solo desprotegido veio abaixo com a erosão, expondo uma rocha imensa que foi a fonte da brita extraída pela Pedreira Montanhão por quase 50 anos e utilizada na construção civil e na primeira pista da Via Anchieta. ${ }^{43}$

Nesse relato, consta também o crescimento desse grupo religioso, que passou a chamar-se Federação Umbandista do Grande ABC - FUGABC - e tornou-se o pólo umbandista mais importante do país.

Sob o ponto de vista desse grupo religioso há total compatibilidade e legitimidade de uso da área, já que os cultos são sempre feitos na natureza, e o fato de terem um local exclusivo para a realização das oferendas poupou de tê-las espalhadas pela cidade, segundo o depoimento de Ronaldo A. Linares (op.cit.). O grupo trabalhou também na recuperação dessa área extremamente impactada pelos anos de exploração da Pedreira, realizando reflorestamento e auxiliando na inibição de ocupações.

Sob o ponto de vista da gestão pública, o santuário apresenta graves problemas. Detém a gestão de uma área tão significativa do Parque do Pedroso

\footnotetext{
${ }^{43}$ Depoimento Ronaldo A. Linares, op.cit.
} 
totalmente dissociada da gestão maior. ${ }^{44}$ Um Relatório Técnico do SEMASA, apontava para alguns dos problemas:

"Construção de vários sanitários e outras infraestruturas de apoio à atividade religiosa e de turismo de massa sem licenciamento ambiental, descaracterizando a paisagem natural da área, impedindo a recuperação da vegetação e impactando a fauna local. Canalização e aterro do córrego do Pedroso para a implantação de locais de oferenda e tendas. Introdução de espécies vegetais exóticas" (Santiago, 2003).

Parte da arrecadação permitida por lei deveria ser revertida ao parque, segundo artigo 33 e 35 da Lei Federal 9.985/2000 (SNUC), os recursos decorrentes de arrecadação devem ser aplicados na própria unidade (Santiago, 2001).

2. A pressão urbana no entorno do parque, que era estimada em 2005, por uma população de 30.000 habitantes, hoje, seguramente, já ultrapassa a marca de 40.000 habitantes (vide tabelas 1 e 2 ).

Antigas sedes de chácaras e olarias, encampadas com a delimitação do parque, foram utilizadas pelo município como local de moradia de funcionários. Foi - caso da área denominada "Olaria" - particular a princípio, que depois de desapropriada também produziu tijolos para o município -, mantendo no seu entorno moradias de funcionários que participavam da produção e de alguns que trabalhavam no viveiro municipal. Foi o maior assentamento interno ao parque, com moradores vivendo há aproximadamente 40 anos, e se mantendo até recentemente, em 2010, quando as famílias residentes foram retiradas da área, e indenizadas por meio de verba proveniente da compensação pelos impactos da implantação do Rodoanel.

Há a descrição de três locais de moradias diferentes, do início de 1970 até 1986, da família do Sr. Miguel Pastor, antigo funcionário do Departamento de Parques e Jardins - DPJ -, que mais tarde tornou-se Departamento de Parques e Áreas Verdes - DPAV. A primeira residência, na Estrada do Montanhão, número 1, situava-se próxima ao edifício de embarque do teleférico. O segundo endereço foi na antiga chácara "Suti", ${ }^{45}$ que, mais tarde, foi cedida através de uma permissão de

\footnotetext{
${ }^{44}$ Depoimento Cristina M. Santiago, op.cit.

${ }^{45}$ Essa denominação foi mencionada nos depoimentos de Maria e Miguel Pastor e Ronaldo Linares.
} 
uso em 1982 para o Desafio Jovem ${ }^{46}$ : Recuperação de Vidas, uma entidade de tratamento especializado para dependentes químicos. A área era utilizada como retiro de jovens, onde desenvolviam atividades de horticultura e outras terapias ocupacionais ${ }^{47}$. O terceiro e último endereço foi atrás da Capela Santa Cruz dos Carvoeiros.

O embrião da Pintassilgo foi uma antiga olaria, onde residiu uma família por volta do ano de 1974. Depois, mais quatro famílias foram morar naquela área com autorização municipal. ${ }^{48} \mathrm{~A}$ permissão oficial, que mais tarde tornou-se permissiva, intensificou-se a partir da década de 1990.

A edificação do chamado Recanto Arco Íris, que atualmente é um edifício utilizado para educação ambiental pela GEMA - Gerência de Educação e Mobilização Ambiental do SEMASA, foi moradia de funcionário municipal. O local de um antigo criadouro de cavalos, conhecido como "haras", abrigou cinco famílias.

\begin{tabular}{|c|c|c|c|c|c|c|}
\hline & $\begin{array}{c}\text { Endereço- } \\
\text { localização }\end{array}$ & $\begin{array}{c}\mathrm{n}^{\circ} \mathrm{de} \\
\text { Domicílios }\end{array}$ & População & $\begin{array}{l}\text { Remoções } \\
\text { pelo } \\
\text { município }\end{array}$ & $\begin{array}{l}\text { Remoções } \\
\text { Rodoanel- } \\
\text { Implantação } \\
2009\end{array}$ & $\begin{array}{c}\text { Remoções pelo } \\
\text { Rodoanel } \\
\text { Compensação } \\
2010\end{array}$ \\
\hline Olaria & $\begin{array}{c}\text { Região norte } \\
\text { do Parque }\end{array}$ & 8 & 28 & - & - & 8 \\
\hline $\begin{array}{l}\text { Desafio } \\
\text { Jovem }\end{array}$ & $\begin{array}{l}\text { Desafio } \\
\text { jovem }\end{array}$ & 1 & 7 & - & - & 1 \\
\hline $\begin{array}{l}\text { Antigo } \\
\text { Haras }\end{array}$ & $\begin{array}{c}\text { Estrada do } \\
\text { Montanhão, } \\
n^{\circ} 115 \\
\end{array}$ & 5 & 15 & - & & 5 \\
\hline & $\begin{array}{c}\text { Estrada do } \\
\text { Pedroso, } \\
n^{\circ} 1.939\end{array}$ & 3 & 7 & - & - & 3 \\
\hline Pintassilgo & Região sul & 730 & - & - & 230 & - \\
\hline Toledana & Limite Norte & 96 & & & - & - \\
\hline Cata-Preta & $\begin{array}{c}\text { Limite } \\
\text { Noroeste }\end{array}$ & & & $2 \overline{5}$ * & - & - \\
\hline
\end{tabular}

* Remoções da Favela Cata Preta foram realizadas em 2007.

Tabela 4. Ocupações. Número de domicílios dentro dos limites do Parque do Pedroso. Fonte: SEMASA-GCA, 2008.

3. Outra atividade já retirada do parque foi o Pesqueiro, com permissão de uso pela Prefeitura por aproximadamente 20 anos. A área inicialmente cedida para moradia foi posteriormente utilizada como pesqueiro. Uma Pista de Kart para

\footnotetext{
${ }^{46}$ A permissão de uso pelo Decreto 12.075, de 23 de dezembro de 1988, foi revogada pelo Decreto $\mathrm{n}^{\circ}$ 14.272, de 23 de fevereiro de 1999.

${ }^{47}$ Santiago, 2003.

48 Depoimento D. Maria e Miguel Pastor, op.cit.
} 
uso recreativo, com permissão de uso pela prefeitura municipal, também foi desativada (Santiago, 2003).

4. Uma nova implantação prevista é a construção da Linha de Transmissão 345 KV Alto da Serra-Sul pela CTEEP - Companhia de Transmissão de Energia Elétrica Paulista.

A implantação aprovada pelo SEMASA prevê uma rede de alta tensão paralela à rede já implantada. No Parque Natural Municipal do Pedroso já existem duas Linhas de Transmissão.

"Trata-se da implantação de nova LT (Alto da Serra-Sul) de 345 KV com extensão de $15 \mathrm{Km}$ (11 km dentro de Santo André) com circuito duplo na maior parte do percurso, e circuito quádruplo abrangendo as Torres 33, 34, 43, 44 e 45, com faixa de servidão ou domínio de 50 m (25 cada lado a partir do eixo), instalação de 34 novas estruturas, com 31 praças de trabalho com $484 \mathrm{~m}^{2}$, e $03 \mathrm{com} 900 \mathrm{~m}^{2}$, onde será necessário a supressão de vegetação destas praças, porém não ao longo da $L T$ onde haverá apenas podas seletivas, conforme declarado no RAP - Relatório Ambiental Preliminar (fl. 35). A soma destas áreas destinadas as praças e que seriam suprimidas totalizam $17.704 \mathrm{~m}^{2}$." Esta nova LT acompanhará outra já existente, ou seja, se implantada haverá aumento significativo de impactos, devido à supressão de vegetação nas novas praças, pela expansão de faixa de servidão e efeitos correlacionados à fauna, além de acentuar processos erosivos. Estes impactos são amenizados nas torres 33, 34, 43, 44 e 45 devido à solução técnica apresentada de circuito quádruplo, no qual uma única torre suportará o cabeamento equivalente a duas torres de 345 KV." (SEMASA, 2008b).

Os impactos causados pela implantação dessas linhas estão relacionados no parecer do SEMASA sobre o Relatório Ambiental Preliminar (RAP), elaborado em 2008, descritos como "efeito de borda".

A manifestação do SEMASA sugeria aguardar a elaboração do Plano de Manejo, que orientaria com zoneamentos e diretrizes para implantação da Linha de Transmissão, considerando o que a Lei 7.733/98, art. 54, § 4 dispõe: "Até que seja elaborado o Plano de Manejo, as atividades e obras desenvolvidas nas unidades de 
conservação de proteção integral devem se limitar àquelas necessárias a garantir a integridade dos recursos e ao cumprimento dos seus objetivos".

Os artigos 24, 33, 46 e art. 48 do SNUC sobre as Linhas de Alta Tensão, dispõem que a empresa concessionária de energia elétrica é obrigada a contribuir financeiramente para a proteção da unidade de conservação.

5. Os acessos viários que seccionaram o parque são a estrada do Montanhão, que liga a estrada do Pedroso ao município de São Bernardo do Campo e dá o acesso ao Santuário Ecológico, a estrada de Sertãozinho também chamada Mico Leão Dourado, que liga Mauá pela Avenida Papa João XXIII, a estrada do Pedroso, o principal acesso entre a Macrozona Urbana e os bairros Miami, Riviera e Recreio da Borda do Campo na área de Mananciais e, recentemente, o Rodoanel Metropolitano Mário Covas, uma estrada Intermunicipal Estadual na porção sul do parque. As consequências dessas vias foram: trânsito de caminhões de lixo para o aterro sanitário Lara, localizado em Mauá, com descarte de lixo antes que os caminhões chegassem ao aterro, supressão de vegetação do parque e das laterais das vias, invasões de áreas públicas e do parque, descarte de produtos perigosos, materiais inertes como terra, entulho, veículos roubados e desmontados, bem como, descarte de cadáveres, atropelamento de diversos animais, como por exemplo, tatu, veado catingueiro, lagarto, cobras, macacos, preguiças, gambá, cães etc., mau uso da via principalmente por veículos de outros municípios, trafegando em alta velocidade, corredor de fauna interrompido, estradas adjacentes aos lagos onde o SEMASA promove a captação de água bruta para o tratamento e abastecimento da população do município de Santo André, a qual estaria inviabilizada em caso de algum acidente com o transporte de produtos agressivos, como resíduos industriais e perigosos, rotineiramente dispostos junto ao aterro sanitário Boa Hora, em Mauá, fácil acesso de caçadores de animais silvestres, vetor de ocupação irregular e desordenada em todo o setor 29 (bairros Parque Miami e Jardim Riviera, Recreio da Borda do Campo), (Santiago, 2003).

Uma das primeiras medidas foi o estreitamento da via e a permissão apenas para veículos de passeio. E, com isso, houve a redução do atropelamento de animais silvestres. Em 2007, as vias foram interrompidas parcialmente, permitindo o acesso apenas ao trânsito da obra do Rodoanel. E em 2010, foram 
fechadas para trânsito público. Apenas o trecho da Estrada do Montanhão que dá acesso ao Santuário por São Bernardo do Campo foi mantido aberto.

O parecer técnico realizado pelo SEMASA e pela Prefeitura Municipal de Santo André para o empreendimento rodoviário denominado Rodoanel Metropolitano Mário Covas-trecho sul, no Município de Santo André, descreve as alternativas de traçados viários que foram elaboradas pela DERSA, desde 1992, sempre abrangendo a região do Parque do Pedroso.

Das três alternativas apresentadas, a primeira, altamente impactante, que se desenvolvia na região central do parque, foi rejeitada, sendo apresentados em 1998 outros estudos elaborados pela DERSA/VETEC, contemplando duas alternativas, uma ao norte e outra ao sul. A alternativa-norte, de menor impacto ao parque, seria desenvolvida por meio de extensos viadutos e túneis (cinco no total). Embora tecnicamente viável, foi demonstrada como sendo inviável economicamente pelo EIA/RIMA, envolvendo 0 reacentamento de aproximadamente 1.500 famílias:

"Os estudos de engenharia de traçado demonstraram que o compartilhamento dos traçados é tecnicamente possível. (...) Entretanto, em razão da tipologia do relevo e dos padrões geométricos associados a compatibilização dos traçados dos dois modais, os estudos demonstraram também que a implantação segundo o traçado da macro diretriz interna só se viabiliza através da implantação de extensos viadutos e túneis, necessários para efetivar a transposição dos morros existentes (...) em razão da magnitude das interferências diagnosticadas com áreas de elevada fragilidade potencial do relevo, da alta intensidade das ações de movimentação de terra, da elevada demanda por áreas de bota-fora (não disponíveis no subtrecho) e dos impactos sobre as áreas de usos residenciais consolidadas, tem sua viabilidade ambiental relativizada, sobretudo se considerada a existência de outras possibilidades de traçado que representem impactos ambientais de menor intensidade" (DERSA/FESPSP, EIA/RIMA, s/d:131,132). 


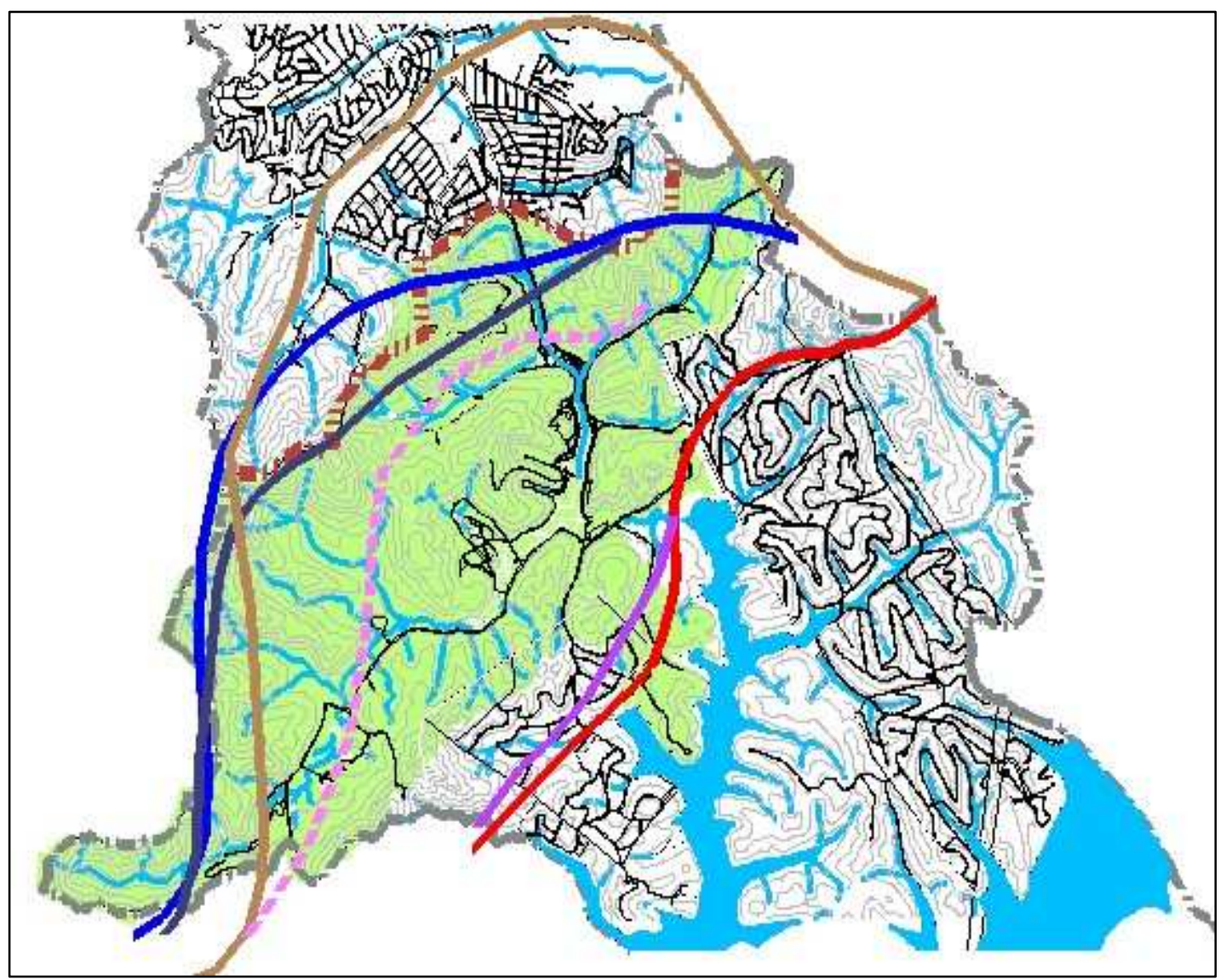

Figura 6. Variações de traçado do Rodoanel Metropolitano no Parque do Pedroso, Trecho Sul-Santo André. Fonte: DGA, SEMASA, s.d.

"A compatibilização dos dois modais" foi uma das justificativas para inviabilizar a opção ao norte. Um dos critérios de avaliação do empreendimento era o compartilhamento com o traçado do Ferroanel, que, na avaliação do EIA/RIMA, seria mais adequado, ao sul das pistas do Rodoanel no Trecho Sul. Segundo o Relatório Final da FESPSP (s/d:5), "a principal vantagem com relação ao Ferroanel ao sul é que permite, dentro da largura padrão da faixa de domínio compartilhada 160 metros -, admitir greides diferenciados entre o Rodoanel e o Ferroanel (...)".

O IBAMA não autorizou a antecipação da execução de alguns componentes do Ferroanel mesmo havendo ganhos ambientais, como as fundações das pontes sobre o reservatório Billings e terraplanagem "no trecho crítico de Santo André", por razões formais, segundo o relatório, antes da conclusão final do licenciamento ambiental específico. 


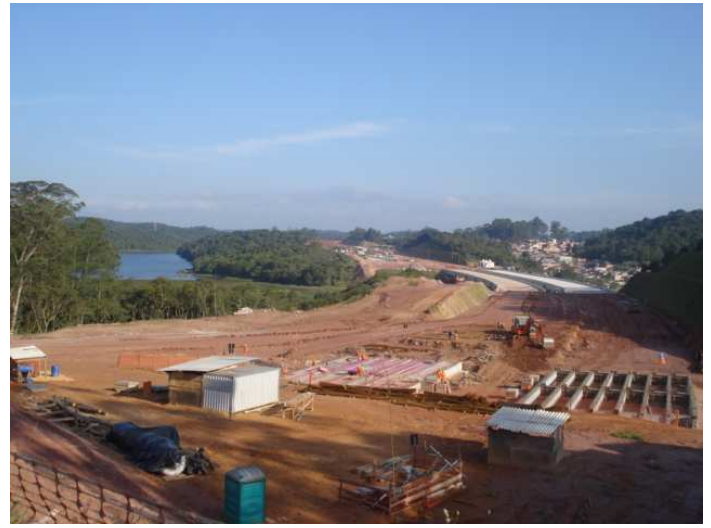

18. Obras do trecho em ponte sobre a Represa Billings. Núcleo Pintassilgo à direita. Fonte: DGA, SEMASA. 2009.

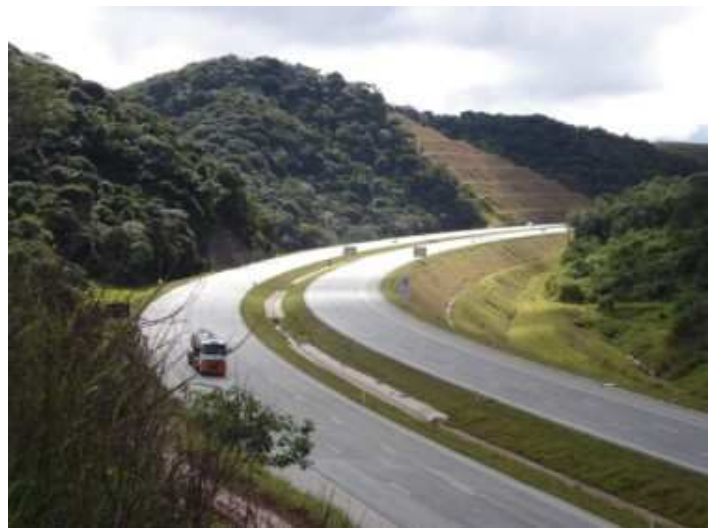

19. Rodoanel implantado próximo ao Bairro Recreio da Borda do Campo. Trecho anterior ao da foto ao lado.

Fonte: Ana Paula de Freitas, 2010.

A equipe técnica do SEMASA avaliou o traçado sul como sendo de expressivo impacto, e o traçado norte, no limite da área da Macrozona Urbana, a alternativa que apresentaria menor potencial de impactos aos meios físico, biótico e antrópico. Destacou a ausência de fundamentação técnica e científica, usual aos EIA/RIMAs de empreendimentos rodoviários e 0 sobrepercurso de aproximadamente quatro quilômetros com uma extensão de um quilômetro de pontes do traçado sul, quando comparado ao norte (SEMASA, 2007).

No Parecer Técnico $n^{\circ} 25 / 2005$, o IBAMA vetou qualquer interferência direta do traçado no interior do Parque Municipal do Pedroso, e a contraargumentação do EIA/RIMA (FESPSP, op.cit.) consistiu na alegação que este posicionamento fugia da jurisdição do IBAMA, "carecendo de base jurídica", sendo que se tratava de Unidade de Conservação da esfera municipal e que a Prefeitura já havia se manifestado favoravelmente ao Traçado Sul.

O Relatório, ao mesmo tempo em que afirmava que a área do parque mais afetada seria uma região parcialmente invadida pela favela Pintassilgo, também reconhecia que o melhor traçado não era necessariamente o de menor impacto à vegetação.

Foram previstas pontes para o fluxo da fauna, (que não foram implantadas), para restabelecer o corredor natural que seria interrompido. parecer do SEMASA indicava que a interrupção desse fluxo provocaria o isolamento do meio biótico do parque, podendo precipitar o declínio ou a extinção de populações animais. 
A avaliação ambiental foi elaborada de forma generalizada e não individualizada por município, o que resultou em um subdimensionamento dos impactos, bem como das medidas compensatórias e mitigadoras, fato considerado especialmente grave segundo o parecer. A rodovia implantada removeu do Núcleo Pintassilgo 230 famílias das 730 que invadiam a área do parque.

Os valores previstos para a compensação ambiental foram destinados para a melhoria de infraestrutura de segurança, para o cercamento dos limites do parque, educação ambiental, elaboração do plano de manejo, entre outros, não optando-se pela regularização fundiária, um dos itens fundamentais para consolidação de uma unidade de conservação.

Foram discutidas as exigências técnicas tanto no Trecho Sul quanto na Serra do Mar e em outras unidades para que a implantação do Rodoanel seguisse um padrão construtivo em superfície, por meio de pontes e túneis e não por corte e aterro, ${ }^{49}$ o que provocou um desflorestamento e uma fragmentação ainda maior do que a que já existia.

A implantação do Traçado Sul afetou áreas públicas, reservas de áreas verdes do loteamento Recreio da Borda do Campo, com o rompimento da ligação entre o parque e a gleba denominada Três Divisas e as demais áreas vegetadas no município de Ribeirão Pires. O parecer técnico solicitou outras alternativas a fim de evitar a interrupção do fluxo gênico e o declínio ou extinção de espécies, e indicou uma área ao leste do Bairro Recreio para ser anexada ao parque (essa mesma gleba Três Divisas).

A estimativa de um total de $138.849,60 \mathrm{~m}^{2}$ em áreas desafetadas do Parque do Pedroso coloca em pauta os problemas de áreas fragmentadas, como o "efeito de borda", modificando o ecossistema atingido pela ação de um conjunto de pequenos efeitos, como as alterações microclimáticas. Estas, entre outras consequências decorrentes de uma fragmentação florestal, serão tratadas a seguir.

\footnotetext{
${ }^{49}$ Depoimento Cristina M. Santiago, op.cit.
} 


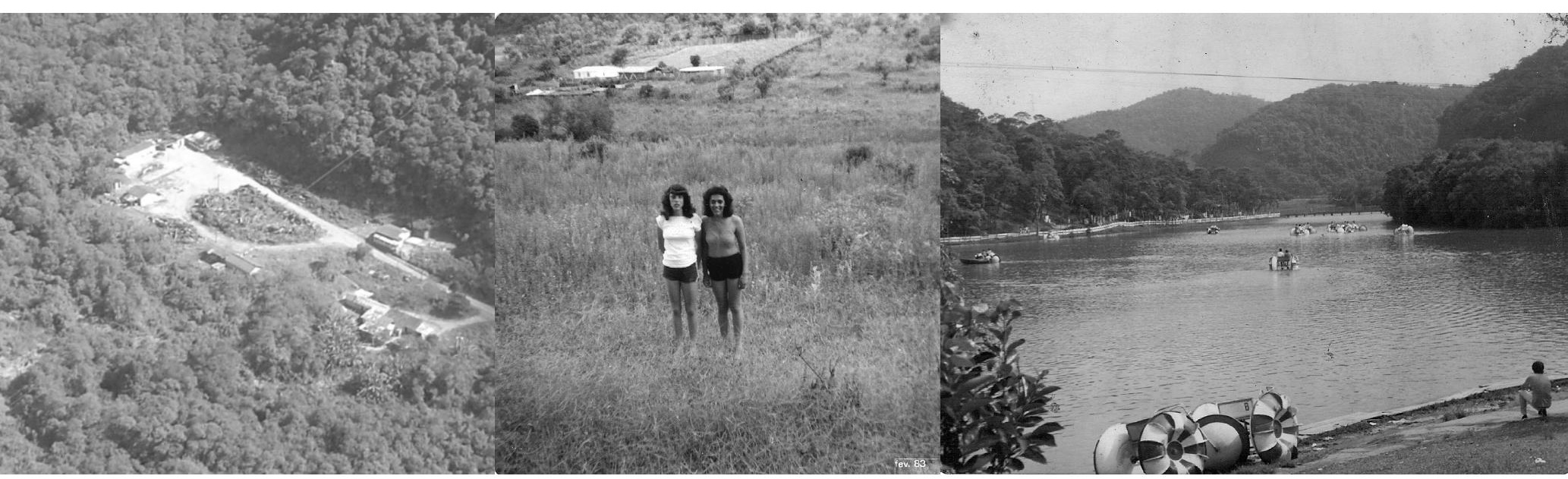

Capítulo II

Fragmentos florestais 


\section{Antecedentes}

A história florestal no Brasil, desde o princípio da colonização, foi marcada pelo desmatamento para ocupação territorial e para utilização da madeira como matéria prima em várias finalidades, passando pelos ciclos econômicos da cana-deaçúcar e do café, até o processo de urbanização, de forma intensa e destrutiva. A consequência dessa exploração foi a redução da Mata Atlântica a aproximadamente 7\% da sua extensão original (SOS Mata Atlântica, 2010).

O que no passado compreendia uma extensa área contínua foi progressivamente transformada em remanescentes isolados uns dos outros, formando pequenos fragmentos de habitats ${ }^{1}$ que representam atualmente uma das maiores ameaças à biodiversidade global.

A maioria das florestas sofreu algum grau de intervenção, como a derrubada seletiva, o extrativismo ou a poluição do ar, de forma que não seria possível afirmar se as florestas remanescentes são exemplares daquela que existiu no passado, com grandes probabilidades que tenham ocorrido extinções locais (Dean, 2002). Cada vez mais, estudos vêm confirmar que os fragmentos não podem ser considerados pequenas réplicas completas do habitat original (Pires, et.al, 2006).

Nesse mesmo sentido, Tricart, apud Scifoni (1994:12) explica que "opor um meio natural a um meio modificado pelo homem nos parece não ter significado. Constitui má colocação do problema, que leva à discussão falsa. No momento atual, já não existe nenhum ecossistema que não seja modificado pelo homem, só que as modificações são de natureza diferente e importância diversa".

Não é possível restaurar as condições originais sob as quais a floresta se desenvolveu. Não é possível, portanto, manejar sua recuperação no sentido de recriar o ecossistema. Mesmo o processo de regeneração natural, diante das condições morfoclimáticas muito distintas da original, produzirá uma nova realidade.

A conservação desses remanescentes tem sido buscada pelos governos e há uma ampla regulamentação apoiando a proteção do bioma. Entender o processo da fragmentação e a viabilidade da conservação da biodiversidade em um fragmento como o Parque do Pedroso são questões que esse capítulo pretende apresentar.

\footnotetext{
${ }^{1}$ Habitat: "a totalidade das características ecológicas de um lugar específico habitado por um organismo ou população de organismos" (Lima e Silva et al., 1999:125).
} 


\section{A exploração da mata na região de Santo André}

Durante todo o século XIX as madeiras foram muito exploradas para a abertura de espaço para agricultura, para construção civil, utilizada em pontes, na ferrovia, para feitura de postes, para o mobiliário, no uso doméstico, para vendas de toras e como fonte de energia através da lenha e o carvão. Eram utilizadas madeiras como Cedro, Jatobá, Jacaré-monjolo e Araribá (Scifoni, op. cit.).

Já no século XVII, havia referências sobre preocupação com a exploração das matas, que provocavam o rebaixamento do nível das águas pelo desmatamento das margens do rio Tamanduateí. ${ }^{2}$ Também, Wanderley dos Santos (1992:79) relata a providência da Câmara de São Paulo em 1810 diante da escassez de madeiras de lei para a construção civil e mobiliária, com o desmatamento para a implantação de roças, desperdiçando as madeiras.

"Fazemos saber a todos os moradores da Freguesia de Santo Amaro, de São Bernardo e do Bairro Caaguacú ${ }^{3}$ (...) que nenhum lavrador possa botar matos abaixo para fazerem plantações sem que primeiro participe ao Capitão José da Silva Carvalho, a quem o mesmo Senado tem nomeado Inspetor Geral das matas dos sobreditos lugares para este mandar tirar todas aquelas madeiras próprias para edificar, ou mandá-las aproveitar por quem lhe parecer, bem entendido que isto é no caso de que o dono das matas não tenha a quem dar para as tirar; que muitas vezes antes querem derrubá-las e queimá-las do que deixá-las aproveitar, cujas partes serão obrigados os ditos lavradores a darem ao Inspetor, um ano antes de fazerem a derrubada (...)"

Segundo Scifoni (op. cit.), a exploração da mata, até o último quartel do século XIX, ocorreu de forma restrita, diante da extensão do território, das grandes distâncias, e enquanto a região contava com um sistema de transporte limitado às

\footnotetext{
"O conjunto dos fatores abióticos (fatores físicos e químicos) indispensáveis à ocorrência de uma dada espécie num local (...). Os habitats são as partes de um mosaico ambiental" (Whittaker et al., 1973; Cerqueira apud Rocha et al., 2006:262).

${ }^{2}$ Martins, apud, Scifone, op. cit.:62.

${ }^{3}$ O bairro de Caaguaçu estava estabelecido, "solidificado", no século XVIII e formava um vasto território. Os bairros São Bernardo e Caaguaçu (ocupando parte do município atual de Santo André, entre o Caminho do Mar e o Vale do Tamanduateí) foram "bairros rurais de povoamento disperso", distribuídos ao redor das grandes fazendas no século XVIII. O Bairro de São Bernardo tornou-se freguesia de São Paulo em 1812 e município em 1889. (Rodrigues, op.cit.:7; 14; 19). Caaguaçu, em tupi guarani, significa "mata grande" (Scifoni, op. cit.).
} 
embarcações e às tropas de burros e com o desenvolvimento de uma atividade agrícola modesta.

O quadro se alterou a partir da instalação da ferrovia e com a criação dos Núcleos Coloniais. A ocupação e o desmatamento intensificaram-se com o crescimento de São Paulo e com a facilidade de escoamento de madeira que era retirada para produção de energia, para movimentação das locomotivas da ferrovia e para os estabelecimentos de produção manufatureira.

"A extração de madeira foi de tal ordem que, em 1901, as autoridades se manifestaram a respeito e, nove anos depois, caía a última mata existente entre São Bernardo e São Paulo. Por esta época, a atividade carvoeira sofreu altas taxações, provocando a reação de seus produtores e comerciantes, entre os quais muitos italianos" (Rodrigues, op.cit.:39).

Toda a mata da atual cidade de São Caetano foi substituída por atividades agrícolas e, na última década do século XIX, já tinha se transformado em uma cidade industrial. Atraídas para a região pela facilidade do transporte e por incentivos fiscais do município, as primeiras atividades industriais compreendiam:

“(..) beneficiamento e a transformação de matérias primas extrativas produzidas nas redondezas. Compreende-se facilmente a conveniência desta localização. A matéria prima era encaminhada até junto à estação e aí era transformada em produtos frequentemente mais leves, mais facilmente transportáveis. Muitas destas indústrias se revestiam de um caráter um tanto quanto rústico, constituindo mero complemento do extrativismo, outras já eram maiores e mais mecanizadas. É o caso, entre outros das serrarias" Langenbuch apud Scifone (op. cit: 80).

São Bernardo manteve-se por um longo período com uma atividade agrícola de subsistência de pequena expressão, isolada pela distância e pelo abandono do antigo Caminho do Mar com a vinda da ferrovia. Ao contrário de São Caetano, até o início do século XX, ainda existiam muitos trechos de Mata de Planalto em São Bernardo do Campo.

A expansão da Província de São Paulo estimulou também o extrativismo mineral, com a extração de caulim, pedra e barro para atender à demanda da 
construção civil, e a madeira era utilizada em toda a região, em olarias, serrarias e carvoarias (Rodrigues, op.cit.).

No final da década de 1920, o Brasil passava pela transição do modelo agroexportador cafeeiro para um novo padrão de acumulação, a industrialização, ${ }^{4}$ e, até essa data, segundo Scifone (op.cit.), aproximadamente metade da área do atual Grande ABC ainda era coberta por matas.

A extração de madeira continuou como atividade econômica importante até a década de 1950, quando a urbanização, estimulada pela construção da Rodovia Anchieta, provocou o esgotamento da matéria prima. Nessa década, o avanço urbano da RMSP contornava as áreas de mananciais e as matas ficaram restritas aos trechos mais periféricos, principalmente próximos ao reservatório Billings ${ }^{5}$.

\footnotetext{
${ }^{4}$ Klink, op. cit.
} 


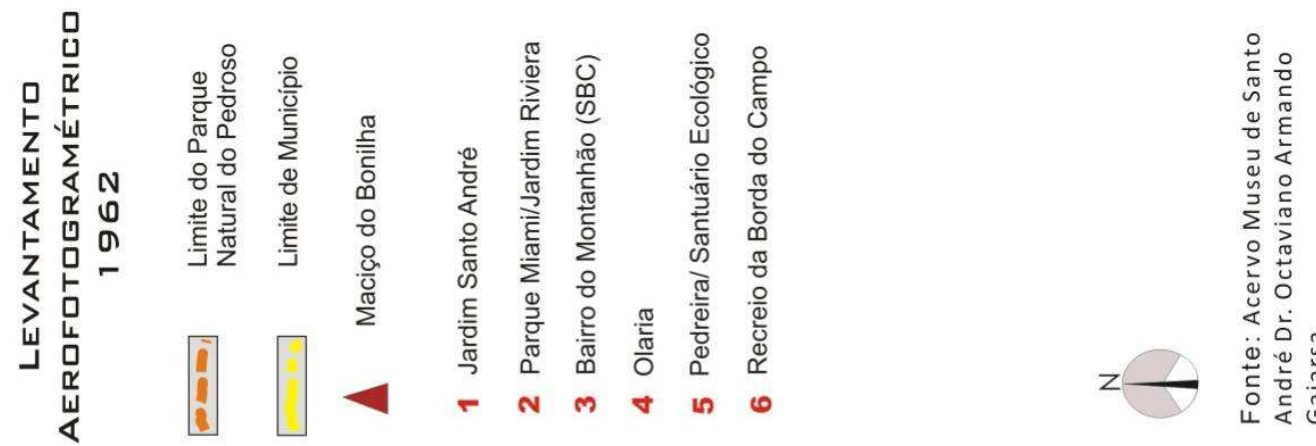

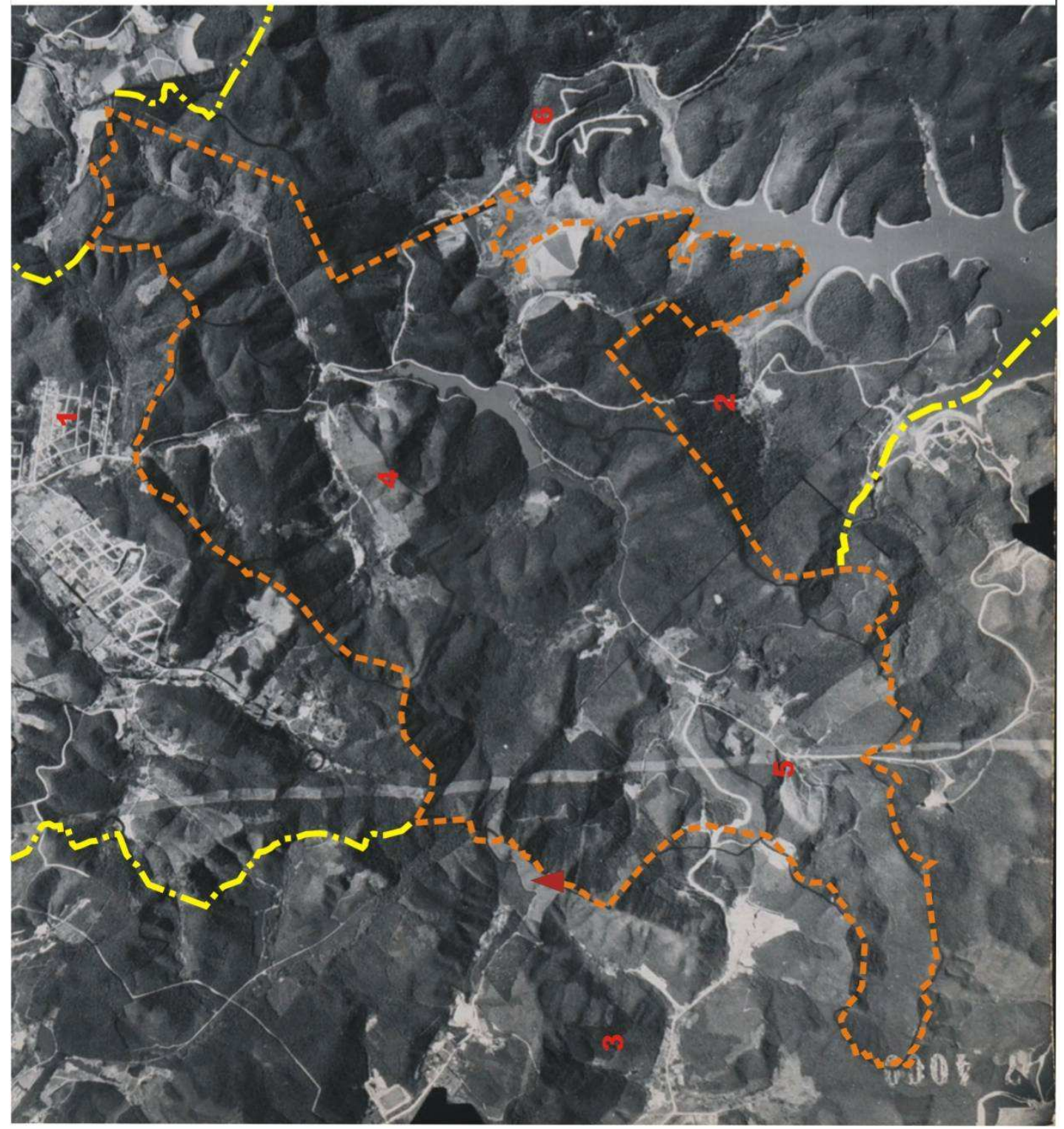

Figura 7. Organização: Robson S. Moreno.

${ }^{5}$ COMDEPHAAPASA, Processo 42725 98/8. 

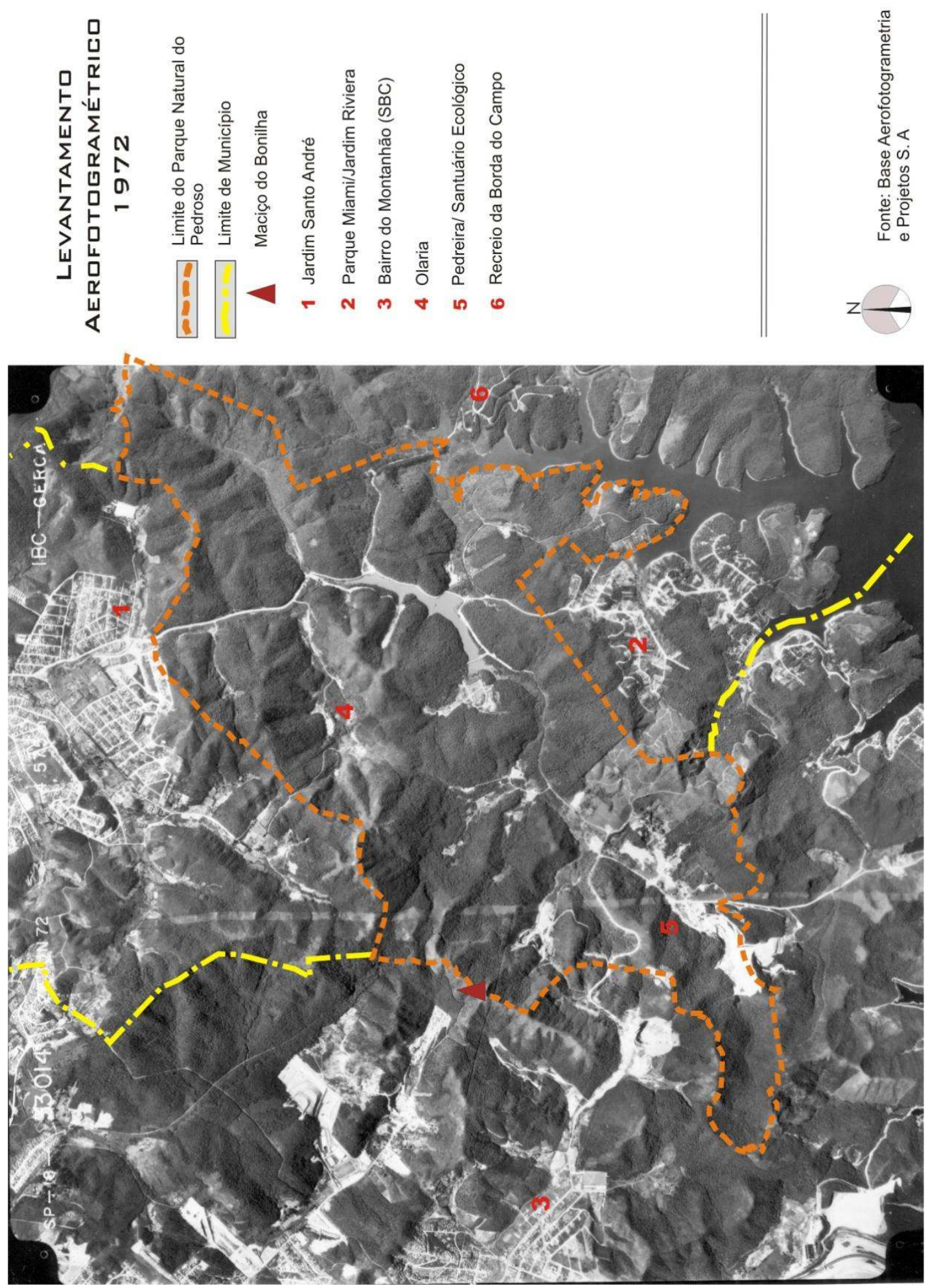

Figura 8. Organização: Robson S. Moreno. 


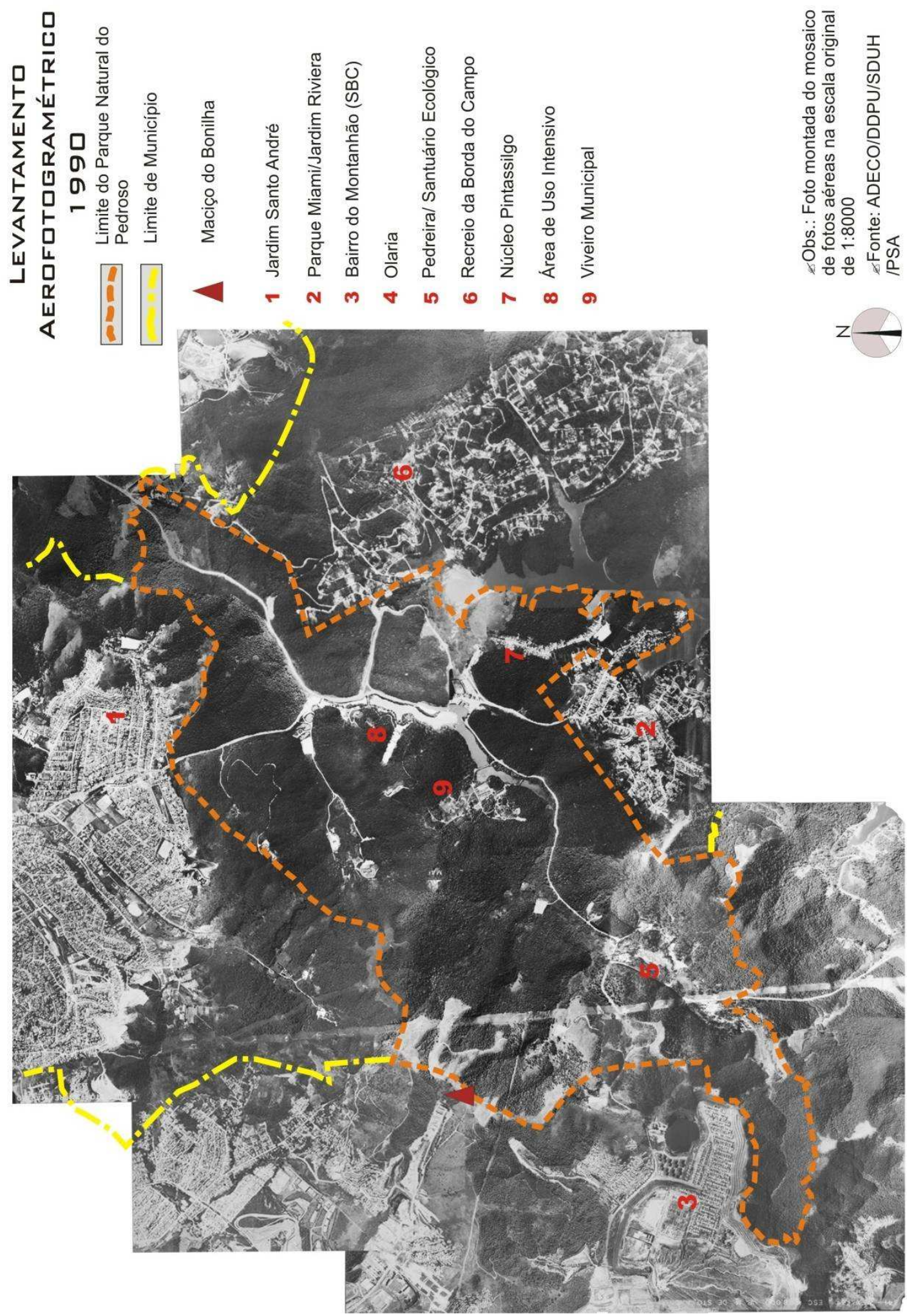

Figura 9. Organização: Robson S. Moreno. 

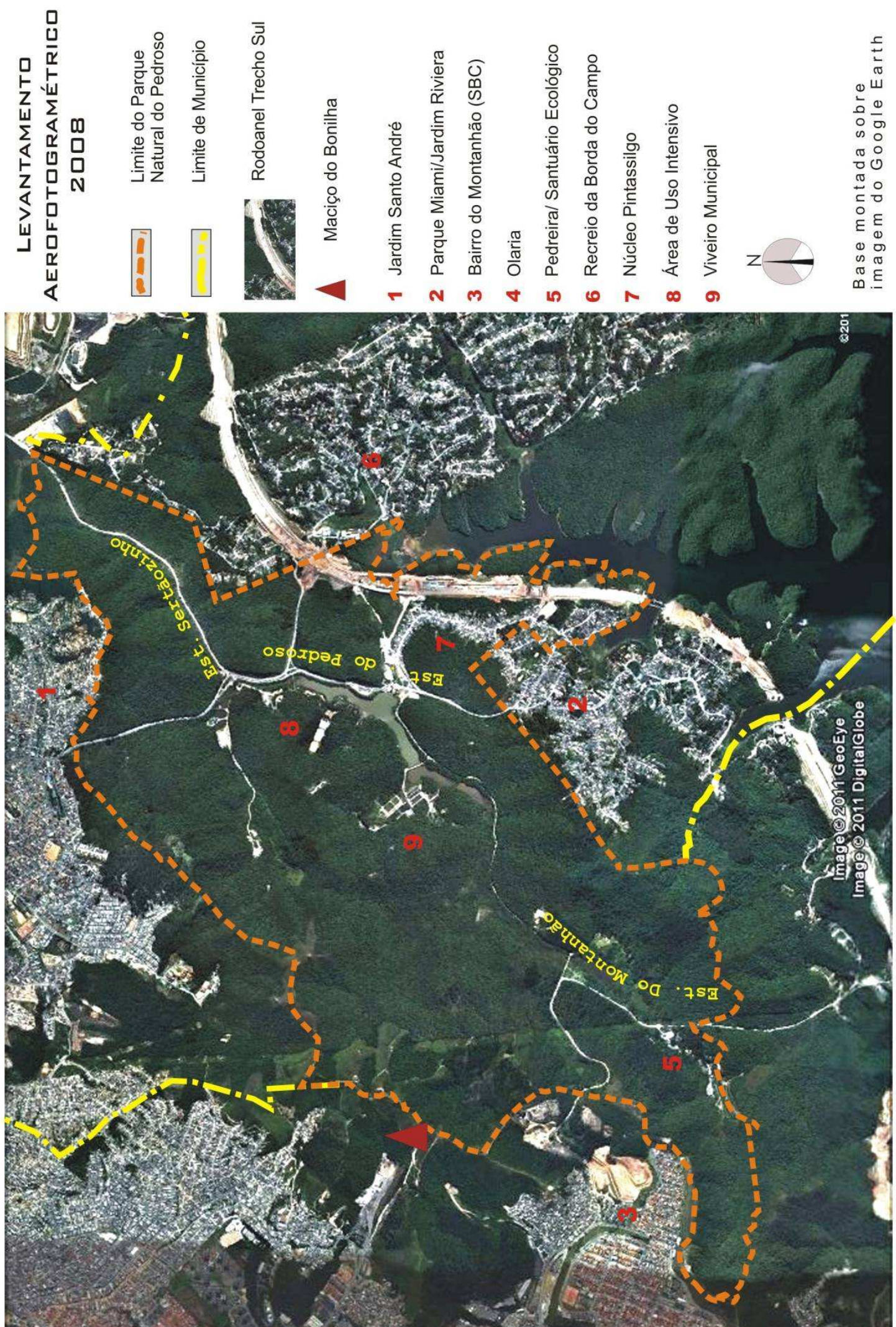

Figura 10. Organização: Robson S. Moreno. 
A sequência de fotos aéreas mostra a alteração das áreas internas e do entorno do Parque do Pedroso no intervalo dos anos de 1962 a 2008. Nas áreas internas é possível verificar a recuperação da mata preenchendo os espaços que configuravam as clareiras. Já na externa, nota-se o avanço das áreas urbanizadas, aproximando-se dos limites e invadindo o parque, tornando-o ainda mais isolado e fragmentado.

Na foto de 1962 há várias clareiras das quais se destacam duas: a Olaria (4) e a Pedreira - o futuro Santuário Ecológico - (5). A Estrada do Pedroso atravessava o parque, assim como a do Montanhão. Parte do arruamento do bairro Recreio da Borda do Campo já estava implantado e as ocupações ao norte e em São Bernardo, a oeste, eram poucas e esparsas.

$\mathrm{Na}$ foto seguinte, a clareira da área da pedreira (5) se acentua e o crescimento do bairro do Montanhão e do Parque Miami (2) é notável. A mancha do bairro Jardim Santo André, ao norte, atinge o limite do parque e a estrada do Sertãozinho ligando a estrada do Pedroso ao município de Mauá estava implantada.

Em um espaço de 18 anos, entre 1972 e 1990, as manchas verdes aumentaram nas áreas internas ao parque, diminuindo as clareiras da Olaria e da Pedreira, e o Núcleo Pintassilgo (7) já se esboçava ao longo de uma via.

A foto de 2008 está marcada com o traçado da abertura do Rodoaneltrecho sul, rasgando o parque e isolando-o dos fragmentos de Mata Atlântica presentes na porção sul e leste. Percebe-se o avanço de favelas ao norte, em especial do Núcleo Toledana (Jardim Santo André-1), e a intensificação das ocupações no entorno do Pedroso nos limites norte e oeste. 


\section{Caracterização Ambiental}

\section{Vegetação}

O bioma Mata Atlântica constitui-se de um mosaico de ecossistemas, com florestas, manguezais, restingas, campos de altitude, brejos interioranos e encraves florestais do Nordeste,${ }^{6}$ com estruturas e composições florísticas variadas devido às diferenças de solo, relevo e clima em sua ampla área de ocorrência no Brasil: ao longo da costa, do litoral brasileiro do Rio Grande do Norte ao Rio Grande do Sul, com grandes extensões para o interior. É considerada como a quinta área mais ameaçada e rica em espécies endêmicas do mundo ${ }^{7}$, reconhecida como Patrimônio Nacional pela Constituição Federal de 1988, art. 225, e Reserva da Biosfera desde 1991.

\begin{tabular}{|l|l|}
\hline Área total do Bioma & $1.103 .961 \mathrm{~km}^{2}$ \\
\hline Área desmatada até 2002 & $834.875 \mathrm{~km}^{2}$ \\
\hline Área desmatada no período 2002-2008 & $2.742 \mathrm{~km}^{2}$ \\
\hline Taxa anual de desmatamento no período 2002-2008 & $457 \mathrm{~km}^{2} / \mathrm{ano}$ \\
\hline
\end{tabular}

Tabela 5: Desmatamento da Mata Atlântica.

Fonte: Brasil, 2010.

A vegetação original predominante na região de Santo André era caracterizada por florestas, denominadas popularmente como Matas de Caaguaçú, Matas do Sertão, sendo que até 1979 a área do Parque do Pedroso, era conhecida como Mata do Sertãozinho (Scifoni, op.cit.).

Há também na região os Campos Naturais que deram origem à expressão "Borda do Campo", no início da colonização. Essas formações correspondem à área de transição entre a Serra do Mar, de topografia irregular e com vegetação densa e diversificada, e a região de campos, onde a cidade de São Paulo foi instalada, em terras que "(...) não produzem árvores altas, senão em pequenos bosques distantes uns dos outros (...)" 8

Os Campos têm como característica solos rasos, estrato herbáceo, cuja altura raramente ultrapassa um metro, onde prevalecem gramíneas, plantas

\footnotetext{
${ }^{6}$ BRASIL, Lei $n^{0} 11.428$, de 22 de dezembro de 2006. Dispõe sobre definições, objetivos e princípios do regime jurídico do Bioma Mata Atlântica.

7 IBAMA, 2001a

${ }^{8}$ Madre de Deus, Frei Gaspar da .Apud Passarelli, (1990:09).
} 
herbáceas heliófilas ${ }^{9}$, como macela (Achyrocline rufecens), assa peixe (Vernonia spp.), plantas floríferas como Salvagesia erecta e Tibouchina sebastionopolitana, íris (Neumarica coerulea), bem como orquídeas terrestres do gênero Habenaria. A presença de poucas espécies de orquídeas terrestres, segundo um diagnóstico das áreas de mananciais de Santo André, UMAH (2000), sugere a origem antrópica da maior parte destes campos com a ocorrência relativamente frequente de fogo.

As formações florestais nativas que integram o bioma Mata Atlântica são compostas principalmente por Florestas Ombrófilas do tipo densa, aberta e mista, e Florestas Estacionais Semideciduais e Deciduais. A Floresta Ombrófila Aberta é a segunda fisionomia vegetal mais devastada, restando pouco mais de $9 \%$ da área original. Floresta Estacional Semidecidual é a fisionomia mais devastada do bioma, restando pouco mais de 4\% da sua distribuição original (SOS Mata Atlântica, 2010).

A diferença de umidade é responsável pela passagem gradual da Floresta Ombrófila Densa ${ }^{10}$, que ocorre em áreas com maior precipitação de chuvas (acima de $2.000 \mathrm{~mm}$ ), sem estação seca, para Estacional Semidecidual, em regiões com menor precipitação, mais afastadas da influência marítima, com estação seca variável (perto de $1.400 \mathrm{~mm}$ ). ${ }^{11}$ As Florestas Estacionais ocorrem destacadamente em regiões mais interiorizadas.

Grande parte da vegetação do Parque do Pedroso corresponde à última formação acima citada, também denominada de Mata de Planalto ou Floresta Semidecídua de Planalto (Hueck, 1956), que é uma formação de clima sazonal, sujeita aos fatores climáticos, como a alta nebulosidade e umidade nos topos dos maciços e pela ocorrência de espécies que perdem as folhas durante a estação seca de abril a setembro, época mais fria e seca do ano. Apresenta fisionomia florestal alta, com indivíduos emergentes de 20 a 25 metros de altura, com copas sobrepostas. Há grande diversidade florística, como as famílias: Leguminosae, Rufaceae, Meliaceae, Euphorbiaceae, Myrtaceae, Rubiaceae e Lauraceae. ${ }^{12}$

"De modo geral, praticamente toda a vegetação da região apresenta interferências antropogênicas decorrentes do processo histórico de ocupação, o que se reflete em sua fisionomia e em sua composição

\footnotetext{
${ }^{9}$ Heliófilas: "da família das Crucíferas, que compreende ervas anuais ou perenes, em parte lenhosas, muitas vezes cultivadas por seus racemos vistosos, longos, de flores azuis-claras com botões brancos. Planta desse gênero". Dicionário Aurélio.

10 Ombrófila significa "chuva", "amiga da chuva".

${ }^{11}$ Torres et al. In UMAH, op.cit.

12 Processo 42725 98/8, COMDEPHAAPASA.
} 
florística. Salvo exceções locais, via de regra, as formações existentes têm caráter secundário. Assim, formações em diferentes estágios de sucessão ecológica alternam-se, formando um mosaico de vegetação em diversos estados de desenvolvimento, entremeadas por formações abertas e por áreas de uso antrópico, inclusive urbano" (UMAH, op.cit.:59).

Há alguns estudos florísticos em Santo André, dos quais se destaca o realizado por Leitão Filho et al., (s.d), para proposta de implantação de um parque urbano, na área denominada Guaraciaba, próxima ao Pedroso, com a caracterização das diferentes fisionomias existentes. Esse levantamento foi indicado por Santiago, ${ }^{13}$ como uma possível referência de um fragmento florestal próximo para a delineação de espécies para o manejo da mata do Pedroso. Outra pesquisa no município de Santo André foram os estudos dos aspectos florísticos e fitossociológicos de um trecho da Mata Atlântica na Reserva Biológica de Paranapiacaba, realizados por Struffaldi-de-Vuono et al, (1989), que identificaram formações florestais mais preservadas.

Os levantamentos mais recentes relacionam-se com a implantação do Rodoanel no laudo realizado para complementação do EIA/RIMA do RodoanelTrecho Sul Modificado, no limite leste (Santo André/Ribeirão Pires) da Área de Influência Direta (AID), e o trabalho de resgate de espécies vegetais pelo Instituto Botânico de São Paulo.

Os levantamentos de campo para o EIA/RIMA foram realizados em quatro fragmentos florestais, inseridos parcial ou integralmente no Parque do Pedroso. Esses levantamentos descrevem uma paisagem com predominância de florestas desenvolvidas, em estágio médio a médio/avançado de regeneração. Foram registradas 879 espécies, sendo 846 magnoliófitas, 31 pteridófitas e 2 pínofitas pertencentes a 127 famílias botânicas. As dez famílias mais ricas em espécies encontradas foram: Myrtaceae (85 espécies), Leguminosae (58 espécies), Rubiaceae e Solanaceae (ambas representadas por 45 espécies), Lauraceae (42 espécies), Melastomataceae (40 espécies), Sapindaceae (27 espécies), Euphorbiaceae (21 espécies) e Orchidaceae (19 espécies).

Das espécies ameaçadas de extinção, segundo Portaria IBAMA n $37-\mathrm{N} /$ 1992, encontrou-se a Araucaria angustifólia, em situação vulnerável, e a Dicksonia sellowiana, em perigo.

\footnotetext{
${ }^{13}$ Depoimento Cristina M. Santiago, op.cit.
} 
O trabalho realizado pela equipe do Instituto Botânico ${ }^{14}$ em julho de 2007, resgatou no trecho sul do Rodoanel Metropolitano, cerca de 20.000 plantas das famílias Bromeliaceae, Cactaceae, Orchidaceae, Gesneriaceae e Marantaceae, na sua maioria epífetas e herbáceas. Muitas delas foram replantadas no Pedroso.

O material ainda encontra-se em estudo, mas já foram reconhecidas mais de setecentas espécies, muitas delas raras, como as identificadas na região do Parque do Pedroso - Leersia ligularis trin e Meroslachys neesii rupr. No parque também foram encontradas muitas espécies exóticas e invasoras.

As plantas coletadas foram enviadas para prefeituras e parques da região, além do próprio Instituto Botânico, e, após a inauguração da rodovia, uma equipe do Instituto auxilia na recuperação das áreas desmatadas.

\section{Fauna}

O endemismo desse ecossistema também se estende à fauna. Das 633 espécies da fauna brasileira ameaçadas de extinção, 383 são predominantemente de ocorrência da Mata Atlântica, reforçando ainda mais a necessidade de proteção desse ecossistema. ${ }^{15}$

Houve o registro de 86 (oitenta e seis) espécies no Parque do Pedroso, sendo $60 \%$ delas insetívoras ${ }^{16}$ ou onívoras, ${ }^{17}$ segundo estudo de MatarazzoNeubauer (1990). Este estudo aponta para a borda da floresta como o habitat preferencial da maioria das espécies (o estrato da vegetação mais procurado, o médio, entre dois e dez metros de altura) e descreve três espécies indicadoras de forte influência antrópica, características de áreas abertas: o pombo-doméstico (Columbia livia), o pardal (Passer domesticus) e o bico-de-lacre (Estrilda astrild).

Na borda da represa Billings observou-se a presença de 37 (trinta e sete) espécies de avifauna, principalmente as onívoras e ictiófagas ${ }^{18}$, de ampla distribuição geográfica, ocorrendo preferencialmente nas margens mais florestadas e em bancos de macrófitas ${ }^{19}$ em locais sem urbanização. As garças (Casmerodius

\footnotetext{
${ }^{14}$ Palestra "Impactos do Rodoanel na vegetação do $A B C$ ", proferida no Museu Octaviano Gaiarsa em 25 de novembro de 2010 pela Taxonomista Dra. Rosângela Simão Bianchini, do Herbário SP-Instituto de Botânica. O trecho sul foi dividido em cinco lotes, para uma logística de resgate, onde cada lote era visitado uma vez para coleta semanal. A região do Parque do Pedroso correspondeu ao lote 1 (um).

${ }^{15}$ Disponível em http://www.sosmatatlantica.org.br/index.php?section=info\&action=fauna. Acesso em

15 de janeiro de 2010.

${ }^{16}$ Insetívoras: espécies que se alimentam de insetos.

17 Onívoras: espécies com alimentação variada (vegetal e animal).

${ }^{18}$ Ictiófagas: espécies com alimentação baseada em peixes.

${ }^{19}$ Macrófitas: vegetação característica de ambientes alagados ou mesmo vegetação aquática.
} 
albus e Egretta) são geralmente encontradas em locais florestados, porém contaminados por esgotos, onde há elevada quantidade de matéria orgânica, propiciando maior atividade biológica.

Em um levantamento de 16 (dezesseis) horas de observação, e entrevistas com funcionários do Parque, foram identificados alguns animais presentes na lista de ameaçados de extinção descrita em decreto estadual, como o gavião-pombopequeno (Leucopternis lacernulata), cateto (Pecari Taiaco), a cutia (Dasyprocta azaral) e o pavó (Pyroderus scutatus). Diante da presença de animais em extinção, alerta-se para a ausência marcante do estrato superior da floresta, ou seja, ausência de um habitat, que é um indicativo negativo para a biodiversidade. Embora o Parque possua extensa cobertura florestal, apresenta ausência de aves próprias do interior da mata (Ackerman, 1998).

Na Mata Atlântica, a maior diversidade de espécies ocorre nos estágios secundários tardios e climáxicos, nos quais a dispersão de sementes se faz principalmente por gravidade, mamíferos roedores e pássaros. Nos estágios iniciais e médios predomina a dispersão pelo vento e por pássaros.

A interferência humana 'oculta' pode provocar a devastação da fauna por meios indiretos. A fumaça que afeta os polinizadores, a contaminação de peixes por mercúrio e sedimentos, a destruição de áreas sensíveis como os locais de nidificação ${ }^{20}$, entre outros fatores, são responsáveis pela existência de 'florestas vazias': "embora imagens de satélites registrem-nas como florestas, elas estão vazias de grande parte da riqueza faunística valorizada pelo homem. Uma floresta vazia é uma floresta condenada" Redford apud Costa Neto (op.cit.:38).

O estudo mais recente foi realizado para a complementação do EIA/RIMA do Rodoanel-Trecho Sul Modificado, onde uma das quatro áreas de amostragem do inventário de fauna foi uma região do Parque do Pedroso. Os estudos se deram na Área de Influência Direta (AID), em sete dias para cada área. Foram encontradas nas quatro áreas 163 espécies de aves e 23 espécies de mamíferos:

- Espécies pouco tolerantes à perturbação: tucano-de-bico-verde (Ramphastos dicolorus) e tiê-do-mato-grosso (Habia rubica);

\footnotetext{
${ }^{20}$ Nidificação: é a ação de alguma espécie de animal construir seu ninho.
} 
- Espécies raras, ameaçadas de extinção: gavião-pega-macaco (Spizaetus tyrannus), araponga (Procnias nudicolis), azulão (Passerina brissoni), águiapescadora (Pandion haliaetus) e macuco (Tyamus solitarius);

- Espécies de mastofauna, características de ambientes de média perturbação, ameaçadas de extinção: bugio (Allouata fusca), gato-do-mato (Leopardus tigrinus), paca (Agouti paca), cutia (Dasyprocta azarae) e tatude-rabomole (Cabassous unicinctus).

Foram capturadas 23 espécies de peixes, correspondendo à cerca de $50 \%$ do total das espécies citadas em estudos para toda a bacia do Alto Tietê, em apenas um pequeno trecho do sistema Billings-Guarapiranga. O gênero Rivullus nunca foi registrado anteriormente na bacia.

No depoimento de Dona Maria e Sr. Miguel Pastor (2009), há a descrição de um animal: "(...) na minha cama tinha uma pantera preta, tão preta...era um gato enorme, lindo! (...) mostrou os dentinhos, mas não atacou. Fez xixi na cama e dentro do meu guarda-roupas (...) ela acabou saindo pela janela para o meio da mata".

Há registros de pegadas e rastros de sussuarana (Puma concolor) e lontra (Lontra sp), identificados pela equipe do Departamento de Gestão Ambiental do SEMASA, que faz o recolhimento de animais silvestres e o encaminhamento para tratamento ou soltura na mata. Este trabalho está inventariado, relatando todos os animais silvestres atendidos e manejados (SEMASA, 2008b).

\section{Relevo}

O município de Santo André está inserido no Planalto Atlântico, com relevo de morros e serras restritas, moderadamente acidentado e amplitudes topográficas variando entre $750 \mathrm{~m}$ e $1050 \mathrm{~m}$ (Santiago, 2003).

O Parque do Pedroso localiza-se na região que corresponde à terceira grande Unidade Ambiental Natural do município, que são os Morros Inclinados do Sul, e está intimamente relacionada ao substrato geológico local. São terrenos assentados sobre rochas cristalinas (Micaxistos ou Metarenitos e Filitos Metassílticos - ambas rochas metamórficas de origem sedimentar, Migmatitos e Gnaisses graníticos - rochas metamórficas de origem ígnea). 
Esta Unidade Ambiental Natural localiza-se ao sul da área mais urbanizada do município (Vila Linda e Vila Luzita mais ao centro, próximo a Mauá, na Vila Guaraciaba, Jardim Santo André, e adjacências, passando pela Cata Preta, Vila Rica, Vila João Ramalho até a região do Sítio dos Vianas, na divisa com São Bernardo do Campo) e se estende a toda a Área de Proteção e Recuperação dos Mananciais, incluindo do Parque do Pedroso até a região de Paranapiacaba. Dessa área deve-se subtrair os rios Grande e Pequeno (Santo André, 2004).

"Essa Unidade (morros inclinados) é a mais problemática do ponto de vista da apropriação para fins urbanos devido às grandes declividades e às grandes amplitudes topográficas entre topos de morro e os fundos de vale, que podem atingir até 150 metros" (Santo André, 2004:34)..

O Pico ou Maciço do Bonilha, o ponto mais alto do Parque do Pedroso e da região, apresenta-se como a mais homogênea subunidade geomorfológica do Planalto Atlântico, em São Paulo, com 986,5 metros de altitude como a cota mais alta (Santo André, 1998).

\section{Clima}

O clima da região está na transição entre subtropical e mesotérmico, apresentando temperatura anual média de $19^{\circ} \mathrm{Celsius,} \mathrm{com} \mathrm{precipitação} \mathrm{anual} \mathrm{de}$ $1.560 \mathrm{~mm}$ e uma umidade relativa do ar ao redor de $83 \%$.

A área de mananciais possui um clima com características peculiares, com alta incidência de chuvas. Paranapiacaba apresenta um dos maiores índices pluviométricos do Brasil (Santiago, 2003).

As alterações morfoclimáticas afetam os fragmentos florestais. O contato próximo com as áreas urbanas proporciona a tendência à redução da insolação direta, de alterações dos valores climáticos de temperatura, umidade e circulação de ar diante de áreas densamente verticalizadas no entorno de maciços vegetais, influenciando diretamente o desenvolvimento de espécies vegetais e na vida animal associada. A germinação de espécies presentes no banco de sementes do solo, fundamental para a regeneração da floresta, num processo de sucessão natural, está ligada aos estímulos ambientais, como luz, temperatura e umidade (Scifoni, op.cit.). 


\section{O processo de fragmentação}

A fragmentação natural acontece em função de diferenças de temperatura, solo e umidade, criando microambientes variados que, somados às interações bióticas, determinam a ocorrência das espécies no ambiente. "As paisagens naturais são mosaicos naturalmente fragmentados" (Olifiers, N. \& Cerqueira, R., 2006:262).

Há, portanto, uma heterogeneidade ambiental representada pelos mosaicos naturais. Porém, a fragmentação drástica, realizada pela ação humana, pode ocorrer rapidamente e em larga escala, provocando modificações acentuadas nos padrões naturais de variação das paisagens.

O processo de fragmentação envolve tanto a divisão do habitat, quanto sua redução total, formando paisagens com pequenas manchas de ecossistemas nativos, comprometendo a biodiversidade a curto ou a longo prazo (Pires et.al., op.cit.).

A curto prazo, a perda do habitat pode levar à perda imediata de espécies, durante o processo de fragmentação, como por exemplo com o desmatamento. A perda também acontecerá se as espécies atingidas forem raras ou se estiverem distribuídas em manchas. A ruptura da continuidade, levando ao isolamento, pode diminuir ou eliminar a colonização ${ }^{21}$ por espécies presentes em áreas vizinhas, impedir o fluxo gênico e o acesso aos recursos fora da mancha do habitat.

A resposta das espécies a longo prazo, segundo Pires et.al. (op. cit.), é influenciada pelo tamanho de cada remanescente, pelo tempo de isolamento e pela conectividade entre as áreas, sendo que neste último fator deve-se considerar a distância entre as áreas remanescentes e seu contexto, ou seja, o tipo de ambiente que as envolve. Outros autores acrescentam o efeito de borda, a forma dos fragmentos, o histórico de seu surgimento e as alterações abióticas na paisagem como fatores que influenciam a conservação da biodiversidade em um processo de fragmentação. 


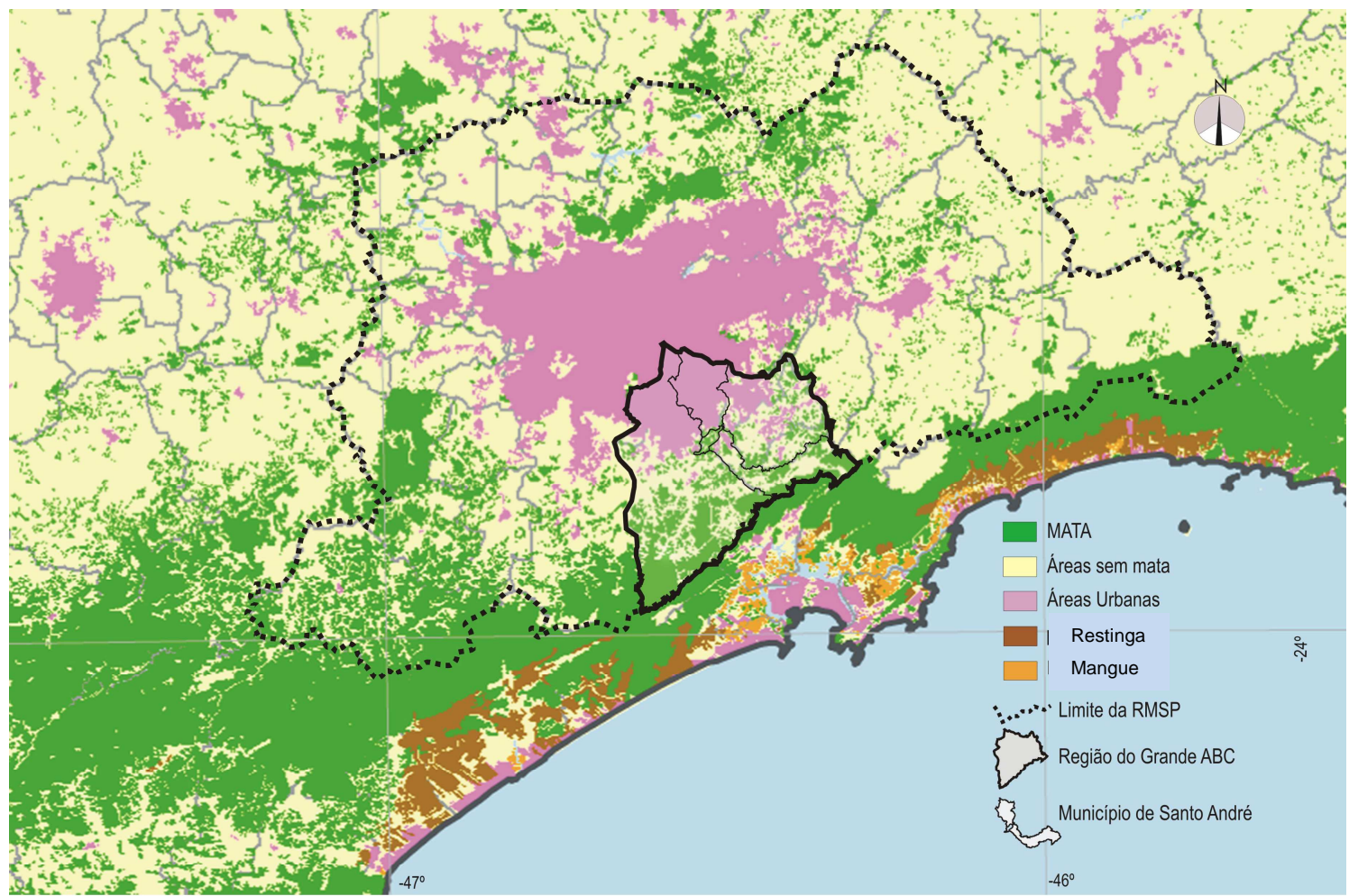

Atlas dos Remanescentes Florestais da Mata Atlântica do Estado de São Paulo - 2008

Fonte: SOS Mata Atlântica e Brasil, 2010

Figura 11. Organização: Robson S. Moreno.

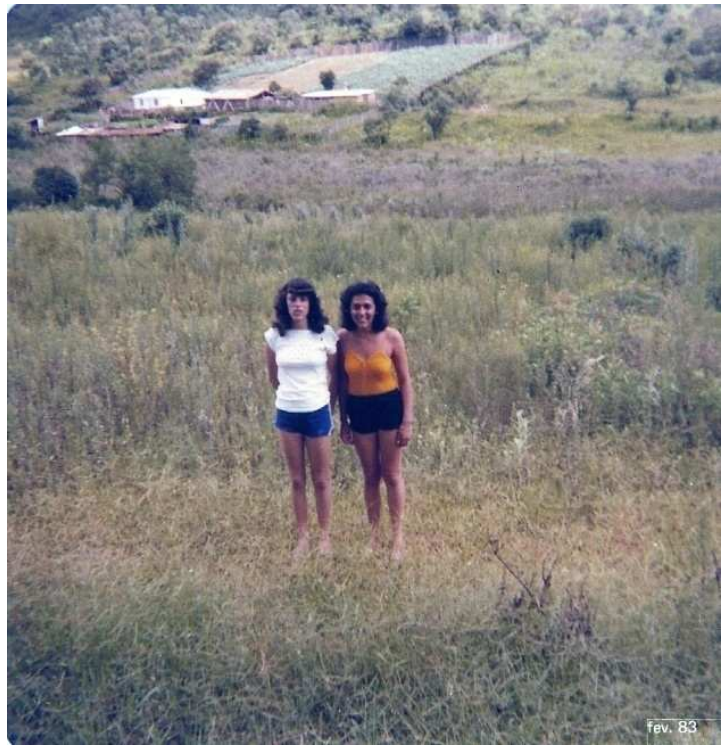

20. Parque do Pedroso. Área não identificada Fonte: Maria e Miguel Pastor [198-].

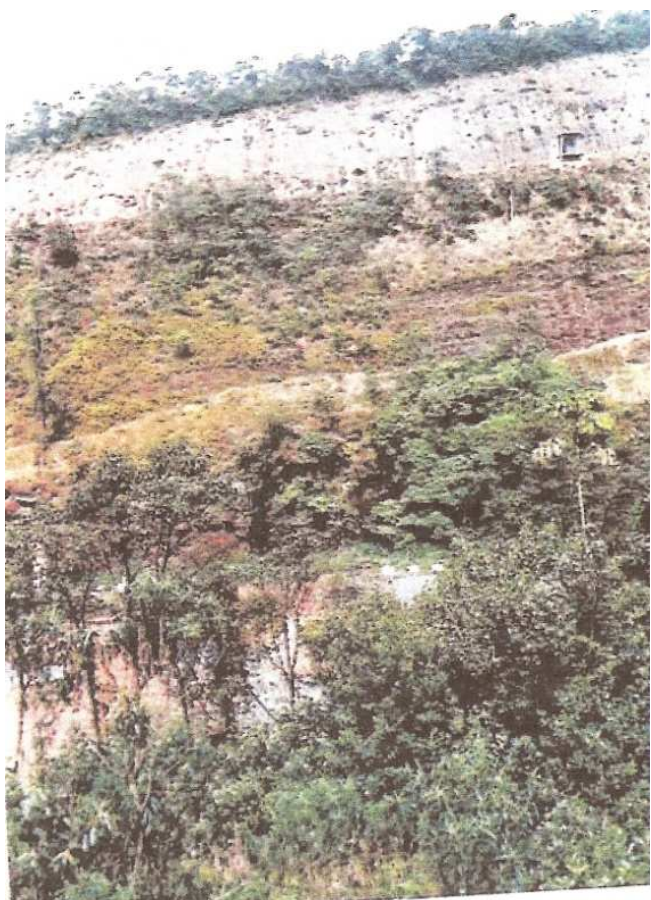

21. Morro cortado na Pedreira Montanhão. Processo de regeneração da vegetação. Fonte: FUGABC, 2005.

${ }^{21}$ Colonização: Ecol. Migração e fixação de uma ou mais espécies num habitat anteriormente carente delas (Lima e Silva et al., op. cit.:55). 


\section{Tamanho}

A relação entre o número de espécies dos lugares com sua área é uma das idéias mais antigas da ecologia ${ }^{22}$. Estudos comparativos de fragmentos da Mata Atlântica com diferentes tamanhos - de cinco a sete mil e novecentos hectares (5 ha a 7.900 ha) - (Tabarelli et al.,1998; 1999) verificaram que fragmentos menores que 20 hectares diferem significativamente de fragmentos maiores na diversidade de espécies da flora e fauna. A proporção de árvores com frutos dispersos por aves ou mamíferos diminui em pequenos fragmentos $e$ isto pode refletir no desaparecimento de muitos vertebrados. Os pequenos fragmentos são mais perturbados, apresentando alta densidade de cipós, lianas e bambus (Korman, 2003: 9-11).

Até 1980, a perda de espécies relacionada ao tamanho da área e a seu isolamento foi explicada pelo modelo do equilíbrio insular de MacArthur \& Wilson (1967), também chamada de Teoria de Biogeografia de Ilhas. Esse modelo preconizava que os fragmentos (ilhas) possuíam o número de espécies proporcional à sua área e a consequente diminuição das populações naturais nesse processo seria gradual até atingir um equilíbrio (Pires et. al.,op. cit.).

Muito embora, o empobrecimento das comunidades após o processo de fragmentação seja bastante previsível, os estudos recentes mostram que não é possível generalizar o comportamento das espécies diante das alterações nos habitats. Há estudos de casos em que se observou o aumento de espécies em fragmentos florestais quando comparado a áreas de habitats originais contínuos. A natureza das relações entre as espécies e delas com o habitat é muito variada e, sendo assim, a resposta das espécies à fragmentação também será. Não é possível, portanto, fazer uma generalização das consequências que resultarão em um fragmento de remanescente florestal. (Olifiers, N. \& Cerqueira, R., op.cit.: 248269).

\section{Isolamento}

De acordo com a Teoria de Biogeografia de Ilhas, o grau de isolamento afeta o número de espécies porque diminui a possibilidade de colonização ou recolonização de espécies vindas de outras áreas e em situações acentuadas de

\footnotetext{
${ }^{22}$ Ecologia: "Ciência que estuda a dinâmica dos ecossistemas, ou seja, os processos e as interações de todos os seres vivos entre si e destes com os aspectos morfológicos, químicos e físicos do ambiente, incluindo os aspectos humanos que interferem e interagem com os sistemas naturais do planeta. É o estudo do sistema natural como um todo e das relações de todos os organismos vivendo no seu interior" (Lima e Silva et al., op.cit.:125).
} 
isolamento; a redução do fluxo gênico entre populações de diferentes áreas pode levar à extinção. A redução da biodiversidade seria maior em fragmentos menores e mais isolados (Olifiers, N. \& Cerqueira, R., op.cit.).

\section{O entorno dos fragmentos}

O entorno, também chamado de "matriz", é definido como "toda e qualquer composição - vegetal ou de outra natureza - que circunde os remanescentes florestais e apresente fisionomia diferente destes" (Olifiers, N. \& Cerqueira, R., op.cit.:270)

Em regiões livres da ação humana, normalmente a matriz pode ser representada por grandes extensões vegetais contínuas, como florestas, cerrados ou campos (Louzada et. al., 2001; Zanini, 2001). Em áreas alteradas pelo homem o entorno pode ser formado por áreas agrícolas, pastagens, estradas, casas e rios.

A matriz permite ou não o deslocamento de espécies entre os fragmentos, interferindo nos processos de colonização e recolonização.

\section{A forma e o efeito de borda}

A forma do fragmento relaciona-se com o efeito de borda. Quanto mais irregular e recortada for a forma do fragmento, maior será o efeito de borda.

Os efeitos de borda ocorrem naturalmente, como aponta Zanzini (2001), e em geral, o encontro de comunidades vegetais nativas distintas pode ser positivo, ampliando a diversidade de animais silvestres nesse local. Entretanto, a borda antrópica, induzida por culturas, pastos, manejo de vegetação, incêndios, erosão e assentamentos urbanos, ou seja, por atividades humanas, promove efeitos negativos nos ecossistemas afetados.

Segundo Murcia (1995), por efeito de borda entende-se o resultado das interações entre dois ambientes limítrofes separados por uma transição abrupta (Paglia et.al. 2006:287).

Vários efeitos conjugados provocados pelas alterações microclimáticas ocorrem no contato entre o fragmento e seu entorno, podendo atingir seu interior e influenciar a estrutura da vegetação e dos animais do remanescente. A maior incidência dos raios solares que penetram no sub-bosque, as alterações na temperatura, umidade e incidência de ventos provocam a maior frequência de queda de árvores e formação de clareiras, aumento de cipós, lianas e plantas de sucessão secundária e a diminuição de espécies vegetais e animais. 
Os primeiros estudos sobre fragmentação mostraram que o efeito de borda pode provocar ações devastadoras e indicaram, por essa razão, que os fragmentos florestais são entidades instáveis (Olifiers, N. \& Cerqueira, R., op.cit.).

\section{Metapopulação}

As populações de uma espécie são distribuídas em manchas de habitats que oferecem as condições necessárias à sua existência, que, segundo a classificação de Rosensweig (1981), são os habitats favoráveis. Com a fragmentação há a tendência de ocorrerem extinções locais, deixando tais áreas (favoráveis) desocupadas.

Essas manchas podem ser reocupadas pela dispersão de espécies vindas de manchas vizinhas, e a essa dinâmica de extinções e recolonizações que persiste dentro de um "balanço" dá-se o nome de metapopulação.

Os fatores que influenciam a recolonização são:

- A capacidade de dispersão das espécies;

- A distribuição das manchas favoráveis na paisagem e o grau de isolamento;

- Quanto mais isolada for a mancha, menor a probabilidade de recolonização;

- Manchas grandes de habitats podem proporcionar uma constante emigração de espécies para manchas menores;

- Havendo populações permanentes nas manchas grandes, até as mais distantes podem vir a ser recolonizadas.

A perda de habitat favorável, aliada ao isolamento acentuado dos fragmentos, pode levar à extinção de espécies (Olifiers, N.\& Cerqueira, R., op.cit.).

\section{A história da fragmentação}

A sequência dos acontecimentos da formação de um fragmento, bem como o tempo total decorrido, além de todos os processos e fatores que influenciaram a paisagem, são considerados parte da história da fragmentação. "Queimadas, desmatamentos, caça, extração seletiva de espécies vegetais, intrusão de espécies exóticas, reflorestamento, regeneração natural e reintrodução de espécies nativas (...)" são os fatos que podem explicar a perda gradual de espécies em decorrência do tempo e da maneira como foram formados os fragmentos. 
Pode-se fazer uma associação entre a composição de espécies e a distância entre os fragmentos, atribuída ao histórico do processo de fragmentação de uma região, somada à capacidade de dispersão das espécies (Olifiers, N. \& Cerqueira, R., op.cit.:274).

\section{Conectividade}

Um destaque maior a esse tema deve-se ao fato de que os corredores ou pontos de ligação ${ }^{23}$ vêm sendo utilizados como estratégia conservacionista desde o início do século $X X$, particularmente para aves, e representam importantes ferramentas para mitigar a fragmentação (Hess \& Fischer, 2001).

A permeabilidade ou a conectividade entre os fragmentos de habitat é influenciada pela presença de pequenas unidades de habitat que se encontram dispersas na matriz, promovendo a permanência ou o deslocamento de algumas espécies silvestres e o grau de resistência que as unidades constituintes da paisagem oferecem ao deslocamento das espécies (Metzger, 1999). Daí a importância dos corredores entre tais fragmentos.

Pontos de ligação (stepping stones) são pequenas áreas de habitat dispersas na matriz que auxiliam nos processos de migração mas não oferecem recursos e área suficiente para sobrevivência das espécies a longo prazo. Matas de galeria e até cercas vivas, árvores isoladas que fornecem alimento, abrigo e locais de pouso são alguns exemplos de pontos de ligação na paisagem. (Jordan, 2000 apud Korman, 2003; Metzger, op. cit.).

Do ponto de vista legal, a preocupação em garantir o fluxo gênico por meio de corredores ecológicos está presente em nossa legislação, mesmo não estando explícito o termo "corredor ecológico". O Código Florestal (Lei $n^{\circ} 4.771$, de 15 de setembro de 1965) mostra que as Áreas de Preservação Permanente - APPs exerceriam essa função ao afirmar no inciso II, $\S 2^{\circ}$ do art. $1^{\circ}$, na definição de APP, que a "área protegida nos termos dos arts. $2^{\circ}$ e $3^{\circ}$ desta Lei, coberta ou não por vegetação nativa, com a função ambiental de preservar os recursos hídricos, a paisagem, a estabilidade geológica, a biodiversidade, o fluxo gênico de fauna e

\footnotetext{
${ }^{23}$ Não há consenso sobre quantas e quais espécies os corredores conseguem manter da fauna e da flora, assim como suas dimensões. Para Metzger (1999) não há estudos suficientes que atestem a eficiência dos corredores para diversas espécies de fauna, restringindo-se muitas vezes à avifauna. Já Laurence \& Laurence (1999) observou seis espécies de mamíferos arbóreos em remanescentes florestais na zona tropical em Queensland, Austrália, daí sugerindo que remanescentes lineares, floristicamente diversificados e apresentando pelo menos entre trinta e quarenta metros de largura, podem funcionar como habitat e, provavelmente, como corredores de movimento para a maioria dos mamíferos arbóreos daquela região (Korman, 2003:16).
} 
flora, proteger o solo e assegurar o bem estar das populações humanas". (sem grifo no original)

Em 1996, por meio da Resolução n 9/96, art. $1^{\circ}$ do Conselho Nacional do Meio Ambiente (CONAMA), estabeleceu-se a definição de corredores de remanescentes de Mata Atlântica: "Corredor entre remanescentes caracteriza-se como sendo faixa de cobertura vegetal existente entre remanescentes de vegetação primária em estágio médio e avançado de regeneração ${ }^{24}$, capaz de propiciar habitat ou servir de área de trânsito para a fauna residente nos remanescentes".

Nos termos do art. $2^{\circ}$, inciso XIX da Lei Federal de no 9.985/2000, que instituiu o Sistema Nacional de Unidade de Conservação - SNUC -, estabelecendo critérios para a criação, implantação e normas para a gestão das unidades de conservação, "corredores ecológicos são porções de ecossistemas naturais ou seminaturais ligando unidades de conservação que possibilitam entre elas o fluxo de genes e o movimento da biota, facilitando a dispersão de espécies e a recolonização de áreas degradadas, bem como a manutenção de populações que demandam para sua sobrevivência com extensão maior do que aquela das unidades individuais". (sem grifo no original).

É importante ressaltar que os termos "corredor ecológico" e "corredor de biodiversidade" muitas vezes são usados para designar estratégias distintas. Alguns pesquisadores e conservacionistas utilizam o termo "corredor ecológico" referindo-se especificamente a trechos delimitados de vegetação nativa que conectam fragmentos. Diferente da definição estabelecida pelo Ministério do Meio Ambiente, assim como as normas citadas, "corredores de biodiversidade" englobam as unidades de conservação e as áreas com diferentes usos da terra. Os cordões de vegetação nativa que conectam fragmentos são um dos componentes dos corredores, mas não os únicos (Brasil, 2006).

\footnotetext{
${ }^{24}$ Pela Resolução CONAMA no 392/2007 (que trata do Bioma de Mata Atlântica localizada em Minas Gerais), "entende-se por: I - vegetação primária: aquela de máxima expressão local com grande diversidade biológica, sendo os efeitos das ações antrópicas mínimos ou ausentes a ponto de não afetarem significativamente suas características originais de estrutura e espécies; II - vegetação secundária, ou em regeneração: aquela resultante dos processos naturais de sucessão, após supressão total ou parcial da vegetação primária por ações antrópicas ou causas naturais, podendo ocorrer árvores remanescentes da vegetação primária".
} 


\section{Ecologia de Paisagens}

Das "ilhas de habitats", ao reconhecimento do papel que desempenhavam outros elementos da paisagem é que surgiu a abordagem da "Ecologia de Paisagens", que, segundo Wu e Hobbs (2002), buscava compreender a relação entre padrões espaciais, fluxos e processos ecológicos que ocorriam em uma escala mais ampla, considerando as interações entre os elementos da paisagem $e$ as espécies, uma vez que a sobrevivência dessas não dependia unicamente dos processos que ocorriam dentro de cada unidade de paisagem ou fragmento, mas também da intensidade de movimentação dos organismos entre as unidades, a qual pode ser influenciada pelo tamanho e proximidade dos fragmentos (Metzger, 1999; Zanzini, 2001).

A perda das interações ecológicas era, segundo Janzen (1974), uma forma mais "sutil e insidiosa" de extinção. Outro autor, Terborgh et.al.(2001), décadas mais tarde, confirmou essa teoria, mostrando como a perda de espécies conduziria à perda das interações ecológicas, provocando mais extinções, numa sequência "em cascata", desmantelando todo o ecossistema (apud, Pires et. al. op. cit:252).

Uma qualidade da Ecologia de Paisagens - ao decifrar a estrutura, a dinâmica da paisagem - foi compreendê-la em relação a seus contextos e processos humanos e naturais. As interações entre o homem e a natureza será abordada no próximo capítulo.

A Ecologia de Paisagens conseguiu traduzir os princípios ecológicos para a escala da prática de planejadores e arquitetos paisagistas e foi aplicada ao planejamento de sistemas de áreas verdes urbanas, de onde se extraiu conceitos para o desenvolvimento dos CVUs - Corredores Verdes Urbanos.

O Plano Municipal de Sistema de Áreas Verdes e Arborização Urbana ${ }^{25}$ incluiu o Parque do Pedroso pelas funções de parque urbano, que corresponde à área de uso intensivo, com aproximadamente $170.000 \mathrm{~m}^{2}$. Está, então, previsto ao Parque, pertencer a

\footnotetext{
${ }^{25}$ O Projeto de Lei do Plano Municipal do Sistema de Áreas Verdes, elaborado no ano de 2006, não foi aprovado.
} 
“(..) um todo articulado e conectado, integrado ao tecido urbano em quantidade, distribuição e qualidade adequadas, atendendo a diferentes funções: paisagística, recreativa, educativa, psicológica e ambiental. Seus elementos estruturadores - parques, praças, unidades de conservação, campos distritais e áreas legalmente destinadas a áreas verdes públicas, ainda que não urbanizadas - serão conectados pelos elementos integradores, tecendo-se uma malha verde sobre a área de abrangência do sistema" (sem grifo no original).

A área do Parque do Pedroso foi objeto de sucessivas fragmentações anteriores a essa última e da drástica implantação do Rodoanel Metropolitano. Como vimos, a utilização das matas como recurso natural fez parte do desenvolvimento da região, passando por todos os eventos listados na história da fragmentação: queimadas, desmatamentos, extração seletiva de espécies etc., fatores que podem influenciar a perda da biodiversidade.

O que se destaca como particularidade, mas não exclusiva ao Pedroso, é seu entorno urbano, densamente ocupado. Uma matriz antrópica de grande proporção em sua borda.

Diante do empobrecimento de comunidades, previsível após um processo de fragmentação, os esforços para conservação da biodiversidade devem concentrar-se na ampliação da conectividade entre as áreas remanescentes e no manejo da paisagem. Pela análise das imagens aéreas e mapas da região, talvez ainda haja a possibilidade de conexão pelo município de Ribeirão Pires.

Como não é possível generalizar as consequências das fragmentações, serão necessários estudos aprofundados para entender qual será o destino da biodiversidade do Pedroso. De todo modo, no que diz respeito a uma abordagem científica aberta a um melhor entendimento das relações entre processos biofísicos e antrópicos, dando pistas para o desenho do ecossistema humano, o campo da Ecologia de Paisagens se constitui uma perspectiva promissora, embora ainda insuficiente para dar conta da complexidade sociocultural presente em espaços dessa natureza. 


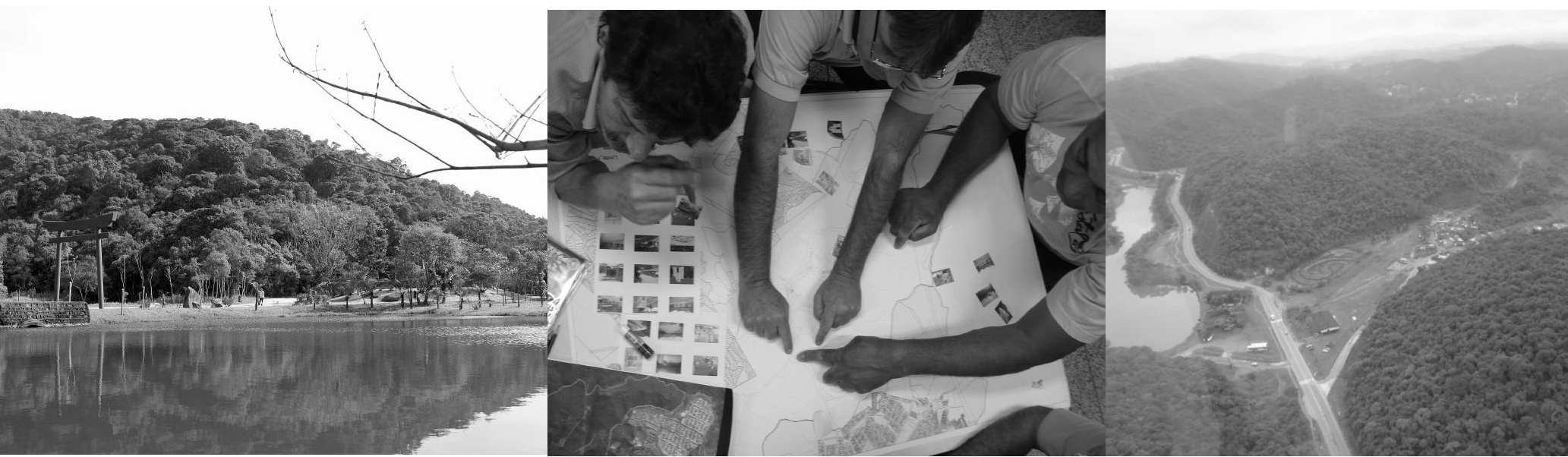

\section{Capítulo III \\ A paisagem e a unidade de conservação}


“(...) Vi que não há Natureza,

Que Natureza não existe,

Que há montes, vales, planícies,

Que há árvores, flores, ervas,

Que há rios e pedras,

Mas que não há um todo a que isso pertença,

Que um conjunto real e verdadeiro

É uma doença das nossas idéias."

(Fernando Pessoa/Alberto Caeiro) ${ }^{1}$

\section{Paisagem}

Paisagem urbana, paisagem contínua, paisagem de Mata Atlântica. Esse uso plural da palavra paisagem, atribuindo-Ihe vários significados, foi utilizado no texto deste trabalho, sinalizando a abordagem que se abre a partir dela.

A paisagem tem sido objeto de estudo de várias disciplinas, como a geografia, a arquitetura, a ecologia, a arqueologia, entre outras, cada uma delas com correntes de pensamento diferentes, sendo que por algumas disciplinas a paisagem é trabalhada como um conceito científico, e por outras como categoria de análise, dada sua variada significação e subjetividade. Este trabalho utiliza a noção de paisagem como categoria, ${ }^{2}$ como um instrumento de reflexão e um enfoque para entender o objeto de estudo, e se utiliza também de definições da geografia, uma vez que, ao longo da história, foi a disciplina que mais se dedicou a refletir sobre ela e que, segundo Ribeiro (2007), de um modo geral incorporou, através da paisagem, a dimensão cultural nos seus trabalhos.

Os textos que falam sobre o Parque do Pedroso tratam-no como um remanescente de Mata Atlântica, mas essa mata "sobrevivente" foi resultado da atividade econômica e social que caracterizou a região até o início do século $X X$, com o uso e ocupação da área por chácaras, fazendas, olarias e carvoarias, caracterizando-o também como um remanescente fundiário ${ }^{3}$.

Esse fato nos leva à paisagem. A natureza de que tratamos é um produto da intervenção humana, uma construção social, sobre a qual manifestam-se as

\footnotetext{
${ }^{1}$ Apud Carvalho, 2003.

${ }^{2}$ A categoria não possui a precisão teórica e descritiva de um conceito, mas reúne um conjunto de elementos que possuem características comuns e contribuem para a elaboração de um conceito científico (Ribeiro, op.cit.:14).

${ }^{3} \mathrm{O}$ remanescente fundiário foi abordado no depoimento concedido por Luis H. R. Zanetta, op.cit.
} 
variadas formas de ver e enfrentar, entre outras questões, a proteção legal das áreas naturais, dentro da visão de mundo que provisoriamente ${ }^{4}$ se estabelece.

Faz-se aqui um breve traçado das motivações gerais do surgimento e de algumas abordagens em torno da noção de paisagem, a fim subsidiar a compreensão deste enfoque no trabalho, como uma síntese da relação entre homem e a natureza.

O aporte teórico-científico proporcionado pela geografia serviu de base para definições da paisagem cultural e para a construção do chamado "patrimônio natural", que também são instrumentos de proteção ambiental e explicitam uma contradição presente na legislação aplicada ao Parque do Pedroso, que são as questões de ordem sócio-culturais, muito latentes no parque diante da interface com uma população numerosa em um contexto urbano.

A paisagem nasce de uma experiência estético-sensível, e foi atribuído ao relato de Petrarca $^{5}$ um valor inaugural à noção de paisagem no ocidente. O desenvolvimento da concepção da natureza como paisagem, da ideia da parte valendo como todo (natureza-paisagem), foi explicada não pela ciência, mas pela literatura e pela arte, pelos sentimentos de quem a observa, num exercício de fruição da natureza. "(...) A paisagem começa na arte, com as primeiras angústias da consciência metafísica, aquela que se inquieta de repente com a sombra que se mexe sob as coisas." 6

A definição da paisagem como um conceito formal surgiu no final do século XIX e início do século $X X$, e ao longo do tempo a paisagem como conceito foi objeto de múltiplas abordagens, sendo que muitos autores não a consideram como um conceito científico devido à carga de subjetividade que carrega por sua dimensão estética e pelas inúmeras interpretações possíveis. A polissemia é uma condição da paisagem e é o que a torna interesse de várias áreas do conhecimento.

\footnotetext{
${ }^{4}$ As sociedades humanas desenvolvem-se num determinado espaço e tempo com visões de mundo provisórias. O poema que introduz esse texto, segundo Carvalho, fala, com a liberdade do poeta, que as "verdades" sobre a natureza são um produto das "nossas ideias". "(..)a natureza (...) deixa de ser vista como uma 'verdade absoluta, e passa a ser parte integrante de realidades sempre provisórias, contra ou a favor das quais os homens investem dependendo daquilo que pretendem: a manutenção ou a transformação destas realidades" (Carvalho, 2003:60).

${ }^{5}$ Atribui-se à escalada de Francesco Petrarca, poeta Renascentista Italiano (1304-1374), ao monte Ventuso um valor inaugural da "postura moderna do olhar direto sobre o mundo" (Besse, 2006:2).

${ }^{6}$ Yves Bonnefoy. Apud Besse, op. cit. prefácio, VIII. Esse texto refere-se ao artista da idade média que não pensaria fazer estudos da paisagem dentro do contexto intelectual de sua época, no qual a felicidade estava no universal e no transcendente: “(...) não se representa o particular (...)". Só com as primeiras angústias da consciência metafísica é que surge a necessidade da representação da paisagem.
} 
Éric Dardel (1899-1968), geógrafo francês, definiria a função da paisagem para a sociedade moderna: "Manter uma relação viva entre o homem e a natureza que o envolve imediatamente. A paisagem desempenha o papel da 'mediação', 0 que permite à natureza subsistir como mundo para o homem" (Besse, 2006:82).

Dentre os vários conceitos - como região, território, espaço e lugar -, foi através da paisagem que se incorporou os aspectos culturais nos estudos da geografia: "A cultura é o agente, a área natural é o meio e a paisagem cultural é $O$ resultado". ${ }^{7}$ No início do século XX, por paisagem natural entendia-se aquela que não havia sofrido transformações pelo homem (intocada), e por paisagem cultural a que seria transformada pelo trabalho do homem.

Dentro dessa concepção ainda não eram consideradas as questões de ordem imaterial. As dimensões estéticas e subjetivas existiam, mas não faziam parte do interesse científico, uma vez que não poderiam ser classificadas e mensuradas dentro da visão positivista que pressupunha a existência de leis gerais.

No final da década de 1960, a partir do rompimento da visão objetiva, positivista, a paisagem passaria a ser entendida além dos aspectos visíveis, dos resultados físicos da ação humana impressos sobre o solo. $\mathrm{O}$ caráter subjetivo e simbólico passaria a ser considerado na definição da paisagem. ${ }^{8} \mathrm{O}$ movimento humanista mostraria que inúmeras abordagens eram possíveis com o consenso na contraposição ao modelo científico anterior e na percepção da paisagem como um "documento a ser lido".

Nessa mesma direção, as novas abordagens da década de 1980 incluíram a questão da subjetividade da paisagem e as várias interpretações a que estava sujeita de acordo com a compreensão de cada grupo, tomando-a como um documento aberto. Foi uma temática abordada por geógrafos como Donald Meining (1979), identificando dez formas diferentes de ver a paisagem: como natureza, habitat, artefato, sistema, problema, riqueza, ideologia, história, lugar e como estética.

Quando passaram a ser considerados os problemas de ordem econômica interferindo nas questões culturais, agregou-se à ideia da simbologia da paisagem o conceitual teórico de fundo marxista. A paisagem através da apreensão dos seus aspectos simbólicos era resultado do meio de produção de uma sociedade: “(...) foram as novas formas de produção introduzidas que consolidaram novas visões de

\footnotetext{
7 Sauer apud Ribeiro, 2007.

${ }^{8}$ Ribeiro, op. cit.
} 
mundo e uma nova percepção da relação entre homem e natureza" Cosgrove apud Ribeiro (op. cit.:26).

Há muitas outras abordagens sobre a paisagem, mas de uma forma geral esse encadeamento de idéias - que não ocorreu de forma linear, já que ao longo da história esse conceito sofreu de recorrente refutação e aceitação - contribuiu para a reflexão sobre a integração entre o homem e a natureza, que só pode ser entendida dentro de um contexto histórico, econômico e social.

No pensamento geográfico está uma das origens da reflexão sobre paisagem, patrimônio cultural e patrimônio natural, cuja discussão não foi contemplada nas categorias de unidades de conservação, na estruturação dos parques nacionais. 


\section{A proteção de áreas naturais}

\section{A abordagem cultural}

O termo "monumento natural" apareceu pela primeira vez no Brasil com a Constituição de 1937, no Decreto Lei $n^{\circ} 25 / 1937$, que instituiu o tombamento e a administração federal que hoje é desempenhada pelo Instituto do Patrimônio Histórico e Artístico Nacional - IPHAN. Denominava os "monumentos naturais bem como aos sítios e paisagens que importe conservar e proteger pela feição notável com que tenham sido dotados pela natureza ou agenciados pela indústria humana". 9

As diretrizes para proteção de paisagens foram definidas no âmbito cultural, tratando-as como monumentos naturais, como os morros da cidade do Rio de Janeiro, tombados em 1973 utilizando-se do decreto citado pela "paisagem de excepcional valor dotado pela natureza". Foram o Pão de Açúcar, Cara de Cão, Urca, Babilônia, Pedra da Gávea, Penhascos Dois Irmãos e Corcovado. ${ }^{10}$

Segundo Scifoni (2004), o que qualificava o monumento natural, além do atributo de paisagem excepcional pela natureza, era a condição de área intocada, inviolável, sem a presença humana, que já estava prevista em 1948 no Decreto Legislativo $n^{\circ} 3$, em aplicação das definições da Convenção para proteção da Flora, da Fauna e das Belezas Cênicas Naturais dos Países da América, realizada em 1940. Essa forma de pensar o monumento natural como áreas sem a presença humana e acessível apenas à pesquisa científica foi uma transposição do modelo conservacionista norte-americano de parques nacionais, importado pelo Brasil.

Na década de 1970 o patrimônio natural se consolida internacionalmente na Convenção do Patrimônio Mundial, Cultural e Natural, documento da UNESCO ${ }^{11}$, e baseado no valor estético e no caráter inviolável o monumento natural continua existindo como uma categoria específica de área protegida. As propostas e revisões seguintes dos documentos, do ano de 1978 e 1994 da União Internacional para a Conservação da Natureza e dos Recursos Naturais - UICN, resultaram na consideração do Patrimônio Natural e as Reservas da Biosfera apenas como designações internacionais. A consequência dessa exclusão se refletiu na elaboração do SNUC, que não considerou os patrimônios naturais como categoria

\footnotetext{
${ }^{9}$ Brasil, 1934, Art. $1^{\circ}$, parágrafo $2^{\circ}$.

${ }_{11}^{10}$ Processo 0869-T-73. (Ribeiro, op. cit.:103).

${ }^{11}$ UNESCO: Organização das Nações Unidas para a educação, a ciência e a cultura.
} 
de manejo, a exemplo de outros países que também reproduziram o mesmo modelo da UICN.

Isso em muito esclarece a proposta para tombamento do Pico ou Maciço do Bonilha como Patrimônio Natural Cultural. A categoria de manejo de unidade de conservação de proteção integral, prevista no SNUC, a qual o parque integra, apresenta lacunas sob o ponto de vista cultural, não considerando o histórico de ocupação, a relação entre a população urbana e a área "natural".

Esse tema vem ao encontro do que Meneses (2002:50) aponta como um "estatuto contraditório dos parques nacionais: são naturais porque são culturalizados". Isso significa dizer que ser natural e merecedor de proteção é uma atribuição de valor, e a definição de valores é determinada dentro de contextos históricos e sociais e são estabelecidos provisoriamente, dependendo da pretensão em manter ou não as realidades. A atribuição de valores é uma construção humana (Scifoni, 2006).

A noção contemporânea de patrimônio natural pressupõe o reconhecimento da ação humana influenciando a natureza e esta como fruto de um processo histórico de apropriação cultural, de forma "que não concebe a natureza e cultura como termos independentes e excludentes, mas como dimensões contraditórias e articuladas que demandam uma abordagem conjunta" (Scifoni, 2006:49).

A Constituição Federal de 1988 incorporou o patrimônio imaterial e também o patrimônio natural designado como "conjuntos e sítios de valor histórico, paisagístico, artístico, arqueológico, paleontológico, ecológico e científico"12 na definição do conceito de patrimônio cultural nacional, acrescentando às questões de ordem estética o reconhecimento das dinâmicas naturais com o termo "ecológico".

Nas discussões recentes em encontros técnicos, do final do século $X X$ e início do século XXI, a separação entre os aspectos culturais e naturais vem se tornando uma ideia superada. ${ }^{13}$

O tombamento do patrimônio natural impõe um regime jurídico específico no Estado de São Paulo regulado pelo CONDEPHAAT ${ }^{14}$-, atrelando o uso do solo

\footnotetext{
12 Brasil, 1988, art.216, V.

${ }^{13}$ Relatório de estudo ao tombamento do Jardim Japonês-Cidade Takasaki. Processo 10.952/2008-2.

14 Conselho de Defesa do Patrimônio Histórico, Arqueológico, Artístico e Turístico do Estado, vinculado à Secretaria de Estado da Cultura, criado em 1969.
} 
às regras de preservação, algumas vezes, atribuindo normas mais rígidas que a legislação urbanística comum, selecionando e restringindo usos e a ocupação do solo, podendo criar outras dinâmicas espaciais e outras possibilidades de exploração econômica com a valorização como patrimônio do Estado. No município de Santo André, essa atribuição é exercida pelo COMDEPHAPAASA. ${ }^{15}$

Há a paisagem cultural como uma categoria de identificação e preservação do patrimônio cultural dos povos (Ribeiro, op.cit.) e o patrimônio natural considerado como uma área especialmente protegida, porém sem o status de uma unidade de conservação, ambos pensados no campo da cultura - dentro das políticas culturais -, fora da esfera de controle ambiental (Scifoni, 2006).

\footnotetext{
${ }^{14}$ Conselho Municipal de Defesa do Patrimônio Histórico, Artístico, Arquitetônico-Urbanístico e Paisagístico da Prefeitura de Santo André. Lei n ${ }^{0}$ 7.091, de 05 de setembro de 2008, instituiu o PPPC - Plano de Preservação do Patrimônio Cultural no Município de Santo André.
} 


\section{O patrimônio dentro da unidade de conservação}

O texto de subsídio ao processo de tombamento do Maciço ou Pico do Bonilha $^{16}$ apresenta os critérios definidos por Aziz Ab'Saber (1977) para preservação das reservas naturais, enquadrando o maciço, bem como a Serra da Cantareira, Pico do Jaraguá, Reserva Morro grande, Serra de Paranapiacaba e Morro Suindara, como "áreas críticas e ecologicamente estratégicas (...)". Dessas áreas relacionadas, ainda não estão tombadas pelo CONDEPHAAT o Maciço do Bonilha e o Morro Suindara.

Áreas críticas, segundo Ab'Saber, seriam massas florestais remanescentes que por sua posição e amplitude podem funcionar como filtros climáticos locais e regionais, com o papel de barrar a expansão da poluição atmosférica, funcionando como zona tampão de defesa ambiental e proteção aos mananciais. "Todas as reservas existentes nos arredores de uma aglomeração urbana metropolitana de crescimento explosivo e desordenado, como é o caso da Grande São Paulo, devem ser preservados a qualquer custo." 17

O Pico do Bonilha faz parte da unidade geomorfológica denominada "morros fortemente inclinados do sul", setor que abrange desde as encostas do Maciço até os limites extremos ao sul dos municípios de São Bernardo e Santo André (Santo André, 1991).

O pico com 986,5 metros de altitude é o grande divisor de águas entre as bacias da área urbanizada e da área de proteção ambiental, ${ }^{18}$ na sua maior parte dentro dos limites do Parque do Pedroso, incluindo algumas propriedades particulares. Os setores norte e leste do maciço são os mais vulneráveis à expansão urbana. Nas cotas mais baixas do maciço (abaixo de $850 \mathrm{~m}$ ) encontramse vários loteamentos e ocupações irregulares, representando além da ameaça ao maciço o risco de escorregamentos, já que são áreas com grandes declividades (acima de 30\%), o que impõe "severas restrições à ocupação".

Há o processo de tombamento pelo município, tramitando desde 1998, e paralelamente também pelo Estado. No processo municipal a proposta de tombamento é justificada pela fragilidade ambiental que a formação apresenta e

\footnotetext{
${ }^{16}$ De Francisco Martins Bonilha, figura pública destacada na região no século XIX, veio o nome do Maciço ou Pico do Bonilha e, desde o início do século XX, o maciço era conhecido como região do "Montanhão", com vários lotes em nome da família Baraldi. Processo 42.725 98/8, COMDEPHAAPASA.

${ }_{17}$ apud processo 42725 98/8:6, op.cit.

18 Santo André, 2004.
} 
pelo avanço da mancha urbana em sua direção. De acordo com as diretrizes de tombamento de áreas naturais, o maciço se enquadra em:

- "Formas de vegetação nativa remanescentes, em especial as áreas onde esta cobertura vegetal esteja ameaçada de extinção iminente;

- Formas de vegetação secundária que se destacam pelo seu valor científico ou pela escassez de formas originais;

- Áreas cuja paisagem mantém o equilíbrio do sistema ambiental, garantindo a manutenção de mananciais (que são feições geológicas e geomorfológicas particulares);

- Toda paisagem alterada ou não pela ação antrópica que se caracteriza pela sua expressividade, raridade e beleza excepcional e pelo que a mesma representa em termos de interesse turístico, social e científico." ${ }^{19}$

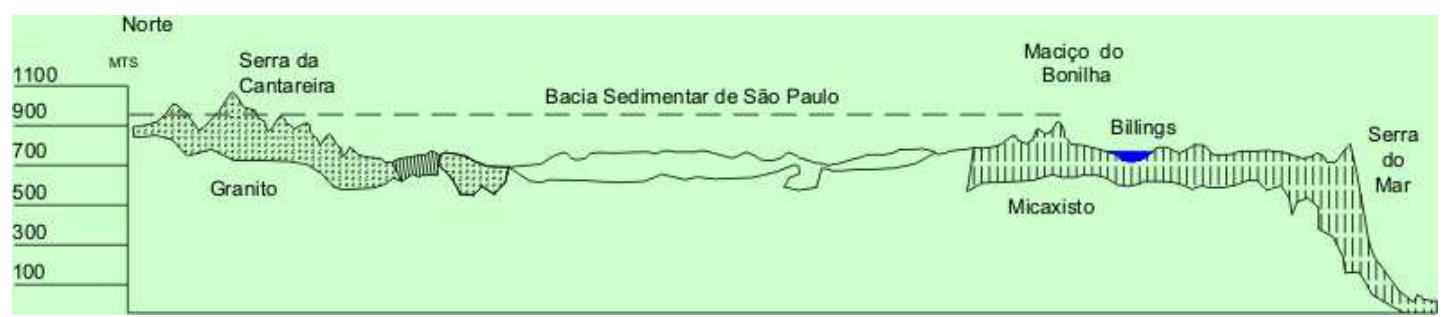

Figura 12. "O Maciço do Bonilha proporciona também uma visão panorâmica, podendo-se observar ao norte grande parte da mancha urbana da Grande São Paulo e a Serra da Cantareira, e ao sul a Represa Billings e os trechos mais elevados da Serra do Mar (Paranapiacaba)." (processo 42725 98/8:7, op.cit.).

Fonte: Ibid:21. Redesenhado por Luciano Augusto.

${ }^{19}$ processo 42.725 98/8:14-15, op.cit. 
O Jardim Japonês "Cidade Takasaki", foi tombado pelo COMDEPHAPAASA na categoria de patrimônio paisagístico ${ }^{20} \mathrm{com}$ a sugestão de inscrição no livro tombo como paisagem cultural e foi inaugurado em 1978 para homenagear os 70 anos de imigração japonesa no Brasil. Essa comunidade faz parte de um dos grupos étnicos que passaram a compor o conjunto da população da região do $A B C$ e de Santo André desde o início do século XX, por volta de 1912.

Em junho de 1999, pela lei ํㅜ 7.837, o Jardim Japonês passou a designarse "Cidade de Takasaki". Um acordo entre a Prefeitura de Santo André e a cidade de Takasaki, no Japão, possibilitou melhorias no jardim no ano de 2001 através do patrocínio da cidade japonesa. ${ }^{21}$

O Jardim Japonês é composto por uma ponte curva, chamada Ponte da Amizade, jardins e lagos, portal denominado Tori, as placas comemorativas e monumentos denominados Takon, com significado de espírito desbravador ou pioneiro. A comunidade japonesa treina o lançamento de anzol na área recreativa, neste local.

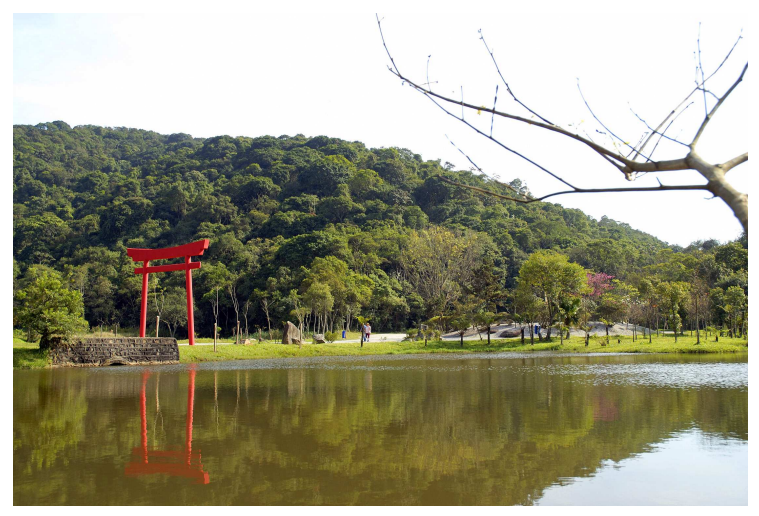

22. Vista geral do Jardim. Tori e local das placas comemorativas à direita (ao fundo). Fonte: CCS, SEMASA, 2008.

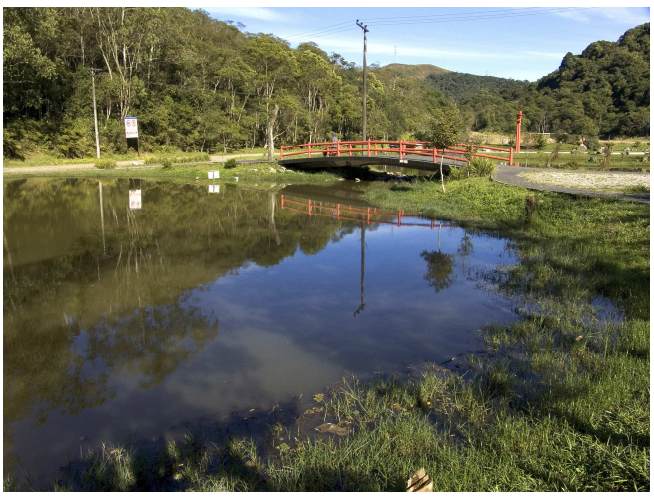

23. Ponte e vista para a via (esquerda) que leva ao local da antiga olaria. Fonte: DGA, SEMASA, 2005.

\footnotetext{
${ }^{20}$ Lei $n^{\circ} 9.071$, de 05 de setembro de 2008, art. 19. Processo 10.952/2008-2, COMDEPHAAPASA .
} 21 lbid. 


\section{A proteção de áreas naturais. A abordagem ambiental}

\section{A influência norte-americana na criação dos parques nacionais brasileiros}

Com o advento da industrialização ocorrido no século XIX incrementou-se a capacidade de operar transformações nas paisagens com o uso mais intensivo dos recursos naturais, provocando alterações mais profundas que em épocas anteriores.

Antes desse período, dessa ruptura, segundo Mumford apud Golub (2010:6), a vida econômica e social tinha um ritmo lento e as primeiras cidades mantinham uma "relação simbiótica com o ambiente natural', cujos impactos sobre a natureza local não eram suficientes para desequilibrar os ciclos naturais, os ecossistemas.

Para a sociedade moderna, no início da revolução industrial a perda do ambiente natural foi valorizada como uma emancipação em relação à natureza e uma condição para conquistar a "liberdade". As cidades foram a base para essa "liberdade" como um sinal de civilização que se opunha a vida rústica do campo. Essa conquista só foi possível através da exploração da natureza e de seus recursos, e como decorrência dessa relação, um alto grau de transformação e degradação do meio ambiente natural e social foi também conquistado. A vida nas cidades, que inicialmente foi valorizada, passou a ser criticada pela poluição causada pelas indústrias e a vida no campo foi idealizada por grupos não diretamente envolvidos na produção agrícola (Diegues, op.cit).

A criação de leis de proteção das áreas naturais na sociedade moderna ${ }^{22}$ decorre da ruptura criada entre a sociedade e a natureza, onde "a natureza original, a natureza livre deve ser protegida contra sua integração ao mundo utilitário da natureza objetivada. Ela é preservada desta objetivação utilitária pela lei" Carus apud Ritter (2008:14).

A partir dessas preocupações, com o agravamento dos problemas ambientais, surgem as motivações para a proteção das áreas naturais: a necessidade de reservar e proteger pedaços de natureza que resistiram ao desenvolvimento urbano-industrial, e de acordo com a experiência americana,

\footnotetext{
${ }^{22}$ O que caracteriza a sociedade moderna é a cidade, a ciência e o trabalho. Na cidade que o homem se liberta da dominação da natureza para fazer dela um objeto de seu próprio poder e de suas necessidades (Ritter, op.cit.:17).
} 
também ao avanço agrícola, que ocasionou uma grande devastação florestal registrada nos Estados Unidos em meados do século XIX.

Este foi o país precursor do modelo de proteção das áreas naturais, selvagens, que se espalhou para outros países do mundo. Foram criados os primeiros parques em áreas naturais de grande beleza e povoados por populações indígenas, algumas delas com intensa atividade humana, como foi o caso do primeiro parque nacional de Yellowstone, criado em 1872, cujos moradores foram expulsos.

Este primeiro parque nacional inaugurou a ideia de proteção a partir de um modelo conservacionista norte-americano que se baseava numa idealização de um paraíso terrestre de regiões selvagens desabitadas, onde o homem seria apenas visitante para fruição das populações urbanas, desconsiderando quaisquer outras formas de ocupação por comunidades, tradicionais ou não, e a relação destas com as áreas naturais, promovendo uma separação entre o homem e a natureza.

A corrente preservacionista foi a base ideológica para o movimento conservacionista norte-americano, defendendo a preservação da natureza sem qualquer exploração econômica de seus recursos e sustentando a ideia de uma natureza apenas para "apreciação estética e espiritual da vida selvagem (wilderness)"(Diegues, op.cit.:30).

O conservacionismo, por sua vez, defendia a utilização racional (adequado e criterioso) dos recursos naturais visando sua proteção mas assegurando a produção de mercado. Essas foram ideias precursoras de outros conceitos sobre o meio ambiente, como "desenvolvimento sustentável" e, posteriormente, para outros enfoques, como o ecodesenvolvimento, na década de 1970. Foi tema de debates nas Conferências de Estocolmo sobre o Meio Ambiente Humano (1972), na Eco-92 (1992) e em publicações como a Estratégia Mundial para a Conservação da UICN/WWF (1980) e em Nosso Futuro Comum (1986).

Em resumo, o ideário norte-americano de parques nacionais previa:

- Conservação de áreas naturais-selvagens idealizadas a partir de uma percepção urbana;

- Não exploração de seus recursos naturais;

- Ausência de populações;

- Acesso apenas à visitação pública com objetivo turístico;

- Controle do Estado em áreas de domínio público. 
Esse modelo foi importado por vários países com realidades socioculturais muito distintas e foi especialmente nocivo às populações tradicionais do Terceiro Mundo com uma visão inadequada de áreas protegidas:

“(...) recriando a dicotomia entre povos e parques, (...) aliada a fatores como: graves conflitos fundiários em muitos países, noção inadequada de fiscalização, corporativismo dos administradores, expansão urbana, profunda crise econômica e a dívida externa de muitos países subdesenvolvidos estão na base do que se define como a crise da conservação" (Diegues, op. cit.:37). 


\section{Os parques nacionais no Brasil}

Segundo Medeiros (2006), o Brasil foi um dos países que aderiram tardiamente à criação de parques (nos moldes norte-americanos), porém houve antecedentes de proteção voltados para o controle sobre o manejo de alguns recursos, como a madeira e a água, no período Colonial e Imperial. O Regimento do Pau-Brasil, de 1605, e a Carta Régia de 1797 foram dispositivos legais visando um disciplinamento rigoroso do uso da madeira (Pau-Brasil). O primeiro foi considerado uma das primeiras leis de proteção florestal brasileira. E a Carta Régia visava o controle do corte não autorizado de madeiras nobres, como cedro, mogno entre outras, um recurso muito importante para a metrópole. O autor atenta para o fato de que a preservação nesse período visava à proteção dos recursos naturais sem necessariamente demarcar áreas ou territórios, o que caracteriza o termo "área protegida".

Uma iniciativa inédita e histórica do Governo Imperial, por recomendação de D. Pedro II, foi a decisão de desapropriação para reflorestamento das fazendas de café que devastaram toda a serra carioca, criando em 1861 a "Floresta da Tijuca e Paineiras" para proteger os recursos hídricos do Rio de Janeiro. Segundo Medeiros (op.cit.), foi uma decisão que esboçou o que mais tarde seria disposto no Código Florestal de 1934 como "florestas protetoras", sendo elencadas no artigo 4ํㅡㄴ como uma das suas funções a "conservação do regime das águas".

Em sintonia com o movimento internacional de criação de parques, várias foram as manifestações no Brasil do segundo reinado em prol da criação de áreas naturais protegidas, mas só se efetivaram com a proclamação da República.

A Constituição de 1934 delegou à União e Estados a responsabilidade de proteção de bens culturais e naturais com caráter conservacionista: "proteger as belezas naturais e monumentos de valor histórico e artístico" (Brasil, 1934 Cap.I, art. $\left.10^{\circ}\right)$.

O Parque Nacional de Itatiaia, criado em 1937, é localizado entre o Rio de Janeiro e Minas Gerais, a Serra dos Órgãos em 1939, no Rio de Janeiro, e o Parque Nacional Iguaçu, no Paraná, também em 1939, foram criados sob a vigência do primeiro Código Florestal de $1934^{23}$ que, além da floresta protetora,

\footnotetext{
${ }^{23}$ O Código Florestal foi instituído por meio do Decreto 23.793, de 23 de janeiro de 1934. Esse código abrangeu "áreas públicas e particulares, com disposições precisas sobre a guarda e cortes de florestas e fixando penalidades por crimes e contravenções" (Costa Neto, 2006:27).
} 
possuía a floresta remanescente, a floresta de rendimento e a floresta modelo como classificações para tipos de manejo.

\begin{tabular}{|l|c|c|}
\hline & No Mundo & No Brasil \\
\hline Antes de 1900 & 37 & 0 \\
\hline 1930 a 1939 & 251 & 3 \\
\hline 1940 a 1949 & 119 & 0 \\
\hline 1950 a 1959 & 319 & 3 \\
\hline 1960 a 1969 & 573 & 8 \\
\hline 1970 a 1979 & 1317 & 11 \\
\hline 1980 a 1989 & 781 & 58 \\
\hline
\end{tabular}

Tabela 6: Número de Áreas protegidas Criadas por Década no Mundo e no Brasil Fonte: Reid \& Miller, 1989. IBAMA, 1989 (estão incluídos parques nacionais, reservas biológicas, estações ecológicas e áreas de proteção ambiental em nível federal somente). Diegues, Op. cit.:16.

Outros dispositivos legais acrescentaram instrumentos para a criação e consolidação das primeiras áreas protegidas, como os Códigos de Caça e Pesca (Decreto 23.672/1934), de Águas (Decreto 24.643/1934) e o Decreto de Proteção aos Animais (24.645/1934), determinando critérios para utilização controlada dos recursos naturais. O primeiro desmembrou-se anos depois em um para caça e outro para pesca, criando determinações para proteção da fauna e da flora e para criação de áreas para reprodução e refúgio. Em 1967 a Lei de Proteção dos Animais representou avanços em relação aos códigos anteriores, prevendo áreas específicas para refúgios e reservas visando a preservação com categorias como Reservas Biológicas Nacionais, onde a caça e a exploração de qualquer recurso era proibida, e Parques de Caça Federais, onde o "exercício da caça" era permitido para fins "recreativos, educativos e turísticos". ${ }^{24}$

O Serviço Florestal, criado em 1921, passa a ter atribuição de orientar, fiscalizar, coordenar e elaborar programas de trabalho para os Parques Nacionais em 1944. Nesse período, os objetivos de um parque nacional eram "conservar para fins científicos, educativos, estéticos ou recreativos (...) promover estudos da flora e fauna e geologia das respectivas regiões, organizar museus e herbários regionais" (Diegues, op. cit.:114). 
O Parque de Paulo Afonso, criado em 1948, mostrou uma evolução lenta na instituição de parques no Brasil, que se concentraram nas regiões sudeste, sul e a partir da década de 1960 foram criados em outras regiões. Nas décadas de 1970 e 1980 houve um crescimento significativo no número de parques, refletindo o contexto mundial voltado para discussões em busca de soluções ao agravamento dos problemas ambientais.

O novo Código Florestal de $1965^{25}$ substituiu as categorias anteriores por quatro outras novas: Parque Nacional, Floresta Nacional, Áreas de Preservação Permanente (APPs) e Reserva Legal (RL). O Instituto Brasileiro de Desenvolvimento Florestal (IBDF), ${ }^{26}$ uma autarquia federal, vinculada ao Ministério da Agricultura, criado em 1967, era responsável pela gestão de todas as áreas protegidas do país.

Na década de 1970, as questões ambientais foram amplamente discutidas internacionalmente em Conferências da Biosfera (1968) e de Estocolmo (1972). Apesar de o Brasil defender posições polêmicas em Estocolmo, aceitando empresas poluidoras no país, em nome do "crescimento" e do "desenvolvimento", o reflexo desse momento ambientalista no Brasil foi o desenvolvimento de Planos Nacionais de Desenvolvimento (PNDs) e o surgimento da SEMA ${ }^{27}$ - Secretaria Especial do Meio Ambiente - em 1973 como resultado da Conferência de Estocolmo e do Clube de Roma.

O IBDF continuou gerindo os parques até então constituídos e a SEMA estabeleceu um programa próprio de áreas protegidas, resultando em propostas de novas categorias, como as Estações Ecológicas (ESEC), Áreas de Proteção Ambiental (APA) em 1981, Reservas Ecológicas (RESEC) e Áreas de Relevante Interesse Ecológico (ARIE) em 1984. As Reservas Particulares do Patrimônio Natural (RPPN) estimularam a criação voluntária de áreas protegidas. Os dois órgãos - IBDF e SEMA - possuíam as mesmas atribuições de implantação e administração de unidades de conservação, e duas propostas iniciais foram formuladas pelo IBDF e FBCN para um sistema único e integrado para as áreas protegidas, uma em 1979 e outra em 1982, constituindo as bases para a criação do SNUC (Medeiros, op. cit.).

\footnotetext{
${ }^{24}$ Lei $n^{\circ} 5.197$, de 03 de janeiro de 1967.

${ }^{25}$ Lei $n^{\circ} 4.771$, de 15 de setembro de 1965 .

${ }^{26}$ Decreto - Lei Federal $n^{0} 289$, de 28 de fevereiro de1967.

${ }^{27}$ Decreto $\mathrm{n}^{\circ} 73.030$, de 30 de outubro de 1973.
} 
A partir de um anteprojeto elaborado pela Fundação Pró-Natureza ${ }^{28}$ e que se concretizaria no ano de 2000, o SNUC (Sistema Nacional de Unidades de Conservação), já sob a atuação do IBAMA $^{29}$ consolidando um sistema único, apresentou os critérios para a criação e gestão de áreas protegidas, estabelecendo doze categorias de Unidades de Conservação divididas em dois grupos: Unidades de Proteção Integral e Unidades de uso sustentável.

O SNUC representou um avanço na regulamentação de áreas protegidas, unificando uma regulação pulverizada em várias leis e códigos e em uma gestão e fiscalização também dividida. Segundo Medeiros (2006), o sistema mostrou-se aberto à criação de novas categorias não previstas, como foi o caso das Reservas Extrativistas (RESEX), que foram criadas por meio da pressão da sociedade como uma reivindicação dos seringueiros da Amazônia para a exploração da floresta. As primeiras RESEXs foram criadas em 1989 no Acre e, em 1990, cinco reservas criadas em Rondônia, Acre e Amapá, não foram efetivamente implantadas. Em 1992, a primeira reserva de pesca artesanal e extrativismo marinho foi criada fora da região amazônica, em Santa Catarina.

Segundo Diegues (op. cit.:118), com o SNUC perdeu-se a oportunidade de se rever e adaptar as várias categorias de proteção à realidade brasileira com uma "grande diversidade de culturas não-industriais, populações indígenas, de seringueiros, pescadores, extrativistas, etc. (...) o SNUC é um 'sistema fechado' isolado da realidade do espaço total brasileiro que tem sido amplamente degradado e 'mal desenvolvido' há décadas." A visão conservadora de UCs como "ilhas de conservação" tem sido criticada pela UICN desde 1986.

Percebe-se que dentro das muitas críticas que esse autor faz ao SNUC, ainda não há menção às populações urbanas, só às tradicionais. No entanto, ele considera que outras categorias de manejo (experimentadas em outros países) poderiam contemplar uma relação mais harmoniosa entre as comunidades locais de moradores dentro e fora das unidades.

Em consonância com a questão abordada por Diegues e ratificando a deficiência do SNUC, está o fato das questões culturais serem tratadas

\footnotetext{
${ }^{28}$ Funatura-organização não governamental, projeto elaborado em 1988.

29 O Instituto Brasileiro do Meio Ambiente e dos Recursos Naturais Renováveis é uma autarquia federal vinculada ao Ministério do Meio Ambiente (MMA). É o órgão executivo responsável pela execução da Política Nacional do Meio Ambiente (PNMA). Em 2007, foi criado o Instituto Chico Mendes da Conservação da Biodiversidade (ICMBio), autarquia responsável pela gestão de unidade de conservação nacionais, retirando do IBAMA esta competência legal. Disponível em http://www.wikipédia.org/wiki/Instituto Brasileiro do Meio Ambiente e dos Recursos Naturais Renov\%C3\%A1veis\#Ver tamb.C3.A9m acessado em 20/11/10.
} 
separadamente das naturais, uma no campo das políticas culturais e a outra na esfera de controle ambiental; essa discussão foi melhor trabalhada dentro da discussões técnicas sobre a paisagem cultural e sobre o patrimônio natural que encaram as áreas naturais protegidas, tanto como "testemunho da evolução de processos ecológicos e do meio físico, como resultado do processo histórico da apropriação social da natureza." A abordagem sobre esses dois aspectos não pode ser separada, deve ser unificada (Scifoni, 2006: 50).

As APAs, Áreas de Proteção Ambiental, são uma categoria de Uso Sustentável que, de acordo com a UICN, integrariam a categoria "V-Conservação de Paisagens terrestres e marinhas, de Lazer e Recreação" (IBAMA, 2001b). Juntamente com as RESEXs e Reservas da Biosfera, que representam uma exceção dentro da estrutura do SNUC, abordando questões culturais, considera-se no caso das APAs, o componente cultural das paisagens entre seus objetivos de proteção e nas RESEXs, a proteção da cultura das populações extrativistas tradicionais.

Segundo Diegues (op. cit.), estas questões culturais são tratadas no SNUC de "forma inócua", já que não há objetivos de proteção da diversidade cultural como uma possibilidade de proteção aos ecossistemas e vice-versa de desenvolvimento regional integrado. Dentro dessa visão antiquada de conservação na escala de importância das UCs, as RESEXs são consideradas de terceira categoria.

As APAs admitem certo grau de ocupação, principalmente em áreas urbanas, sem necessariamente a aquisição das terras pela União ou estados e municípios, podendo ser constituídas em domínios públicos ou privados.

Os Parques Naturais Regionais da França foram referências na estruturação da categoria de APAs e foram pensados, a partir da decisão de comunidades locais, para preservar e desenvolver os territórios onde habitam (IBAMA, 2001a).

As Reservas da Biosfera apresentam similaridades com as APAs e integram o SNUC como um modelo internacionalmente adotado de gestão integrada, participativa e sustentável dos recursos naturais, tendo entre seus objetivos a preservação da diversidade biológica. A Reserva da Biosfera pode ser integrada por uma ou várias unidades de conservação, de domínio público ou privado e prevê a presença de populações tradicionais (extrativistas, pescadores artesanais) nas UCs. 
São conceituadas como "zonas de ecossistemas terrestres ou costeiros / marinhos, ou uma combinação dos mesmos, reconhecidas no plano internacional no marco do Programa sobre o Homem e a Biosfera (MAB), da Unesco."30 A primeira Reserva da Biosfera foi criada em 1992 e abrange uma área significativa da Mata Atlântica em vários estados do sul e sudeste do Brasil, muito embora, segundo Diegues (op.cit.), o grande espaço territorial dessa reserva pouco contribuiu para resolver o problema dessas populações nas unidades de uso restritivo (parques, reservas biológicas, estações ecológicas).

As semelhanças entre as categorias das APAs e Reservas da Biosfera são:

- Têm por objetivo, conservar a biodiversidade;

- Admitem o uso sustentável dos recursos naturais;

- Podem ser constituídas em propriedades privadas;

- Possuem sistema de planejamento com ordenamento territorial, a partir de zoneamento com zonas de diferentes graus de proteção, restrições e permissões;

- O sistema de gestão adotado é realizado de forma participativa e visa contribuir com a melhoria da qualidade de vida da comunidade.

${ }^{30}$ Estatuto da Rede Mundial das Reservas da Biosfera (IBAMA, 2001b). 


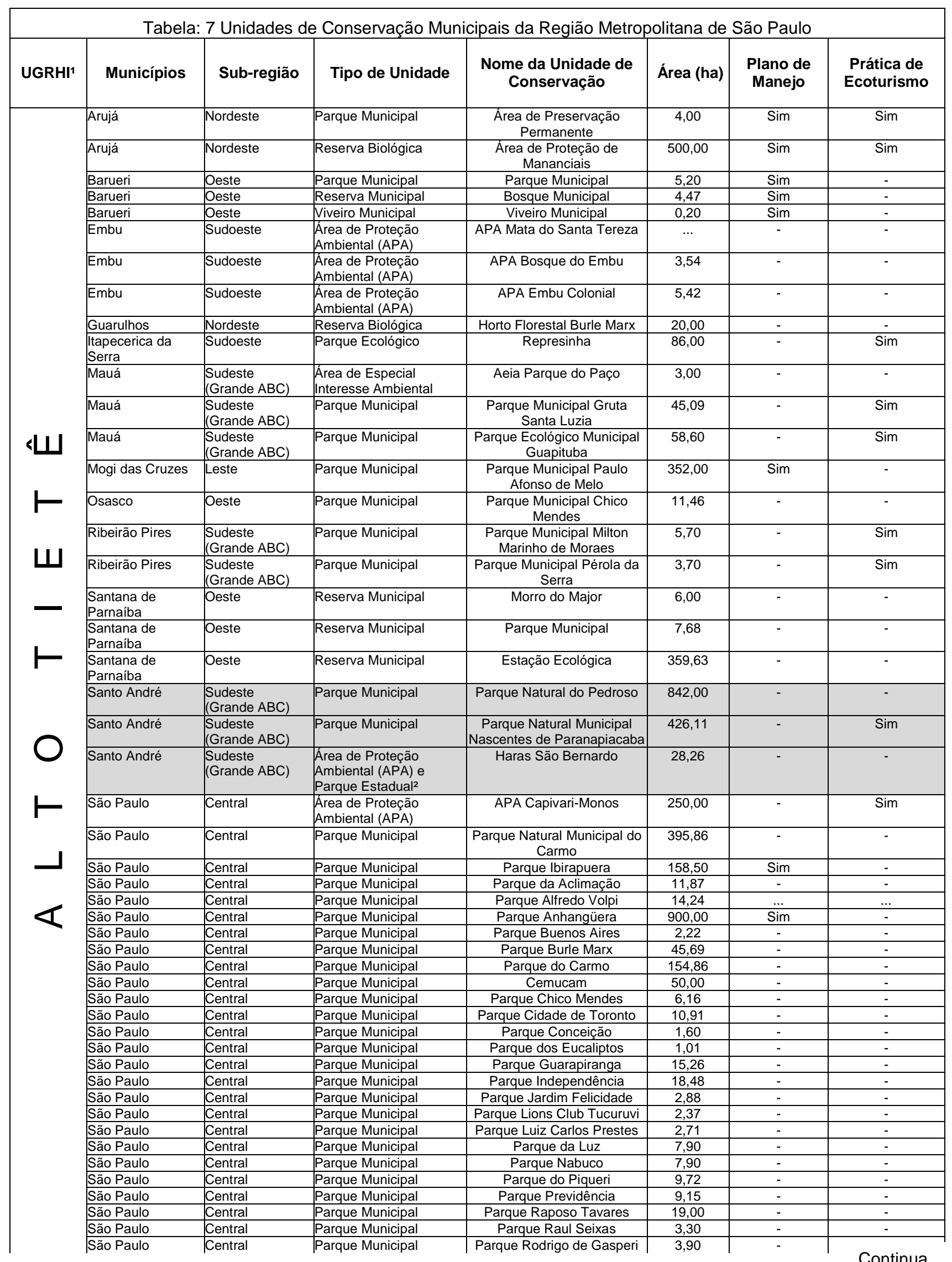




\begin{tabular}{|c|c|c|c|c|c|c|c|}
\hline UGRHI' & Municípios & Sub-região & Tipo de Unidade & $\begin{array}{c}\text { Nome da Unidade de } \\
\text { Conservação }\end{array}$ & Área (ha) & $\begin{array}{c}\text { Plano de } \\
\text { Manejo }\end{array}$ & $\begin{array}{l}\text { Prática de } \\
\text { Ecoturismo }\end{array}$ \\
\hline & São Paulo & Central & Parque Municipal & Parque Santa Amélia & 2,70 & - & - \\
\hline & São Paulo & Central & Parque Municipal & Parque Santo Dias & 13,40 & - & - \\
\hline & São Paulo & Central & Parque Municipal & Parque São Domingos & 7,92 & - & - \\
\hline \multirow{8}{*}{ 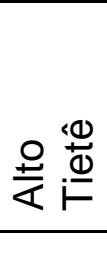 } & São Paulo & Central & Parque Municipal & Parque Severo Gomes & 3,50 & - & - \\
\hline & São Paulo & Central & Parque Municipal & Parque Siqueira Campos - Trianon & 4,71 & - & - \\
\hline & São Paulo & Central & Parque Municipal & Parque da Vila Guilherme & 6,20 & - & - \\
\hline & São Paulo & Central & Parque Municipal & Parque Vila dos Remédios & 10,98 & - & - \\
\hline & São Paulo & Central & Parque Municipal & Parque Chácara das Flores & 4,20 & - & - \\
\hline & São Paulo & Central & Parque Municipal & Parque Vila do Rodeio & 61,20 & - & - \\
\hline & São Paulo & Central & Parque Municipal & Parque Darcy Silva & 0,36 & - & - \\
\hline & \multicolumn{4}{|l|}{ TOTAL } & $4.998,72$ & & \\
\hline
\end{tabular}

1 Unidades de Gerenciamento de Recursos Hídricos e Municípios

2 Em 2009, foi assinado o convênio entre Estado e Prefeitura de Santo André para que a gestão da Chácara da Baronesa do Estado para o Município de Santo André

${ }^{3}$ Fonte: SEADE/EMPLASA, 2003; GONÇALVES \& MORENO, 2009 e SANTO ANDRÉ, 2009.

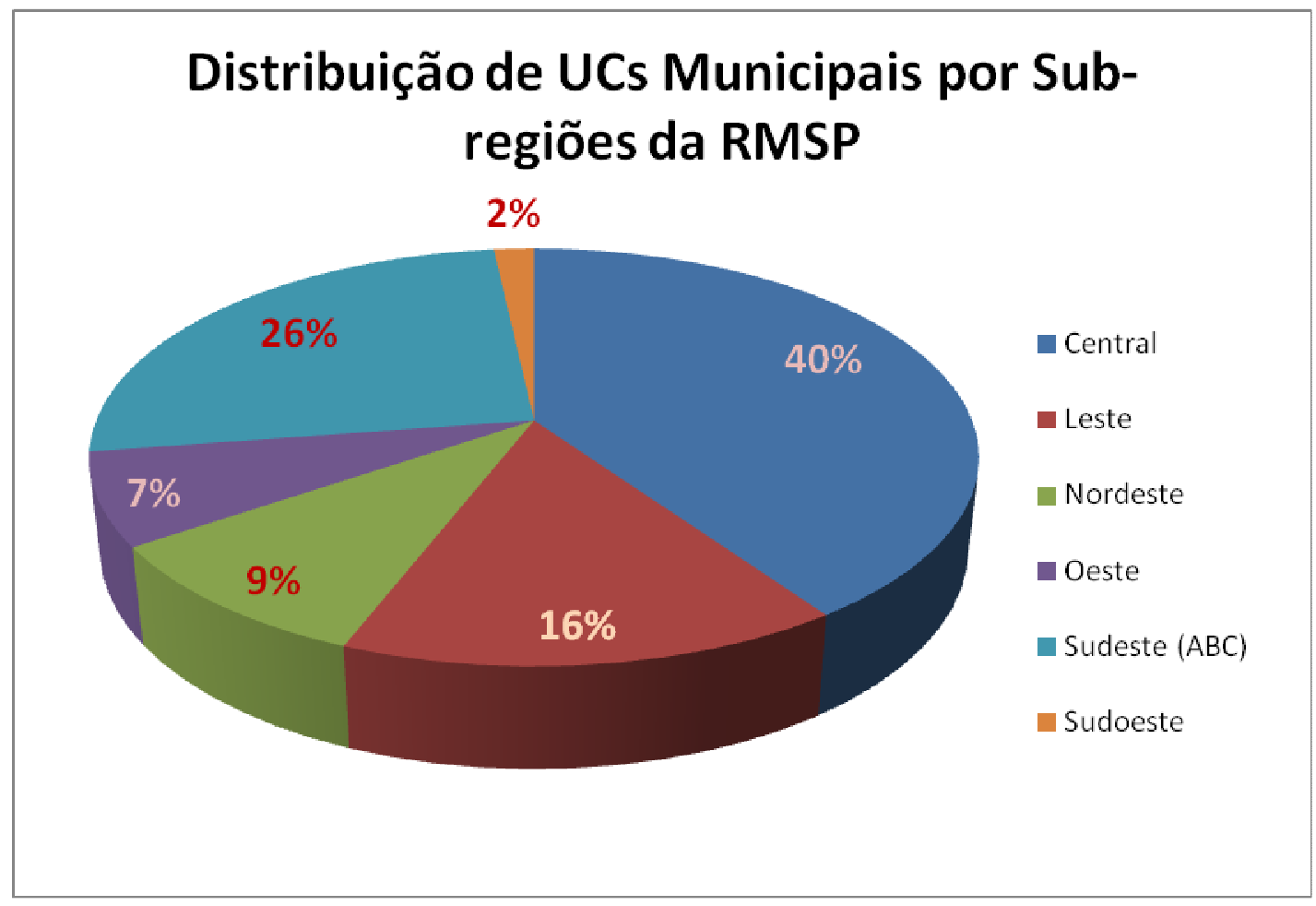

Gráfico 2

Fonte: EMPLASA, 2003; GONÇALVES \& MORENO, 2009 e SANTO ANDRÉ, 2009 


\section{O Parque Natural Municipal do Pedroso:}

\section{Uma unidade de conservação de proteção integral em área urbana}

A unidade de conservação foi criada por lei municipal ${ }^{31}$ em 1998, indicando suas características naturais como uma justificativa para a categoria que se incluía o então Parque Regional e Jardim Botânico. A denominação Parque Natural Municipal do Pedroso foi alterada em $2006^{32}$, enquadrando-o na classificação do SNUC, no grupo das unidades de proteção integral. Pode-se afirmar que o objetivo principal da criação da unidade de conservação foi estabelecer "garantias adequadas de proteção" para a conservação dos recursos naturais, diante da pressão que exercia a expansão urbana em Santo André, intensificada na década de 1970.

O Parque do Pedroso originou-se com a reserva de áreas, na década de 1940, para captação de águas de abastecimento da cidade de Santo André de forma semelhante a outros parques estaduais formados para a proteção dos mananciais de água, como o Horto Botânico, em 1896, no Estado de São Paulo, que passou a chamar-se Horto Botânico e Florestal em 1909 e, em 1911, Serviço Florestal, tornando-se o atual Instituto Florestal. "O Horto Botânico, hoje sede do Instituto Florestal, foi instalado em uma área desapropriada próxima às Matas da Cantareira, protegendo a área de mananciais de abastecimento da cidade de São Paulo" (Costa Neto, 2006:39). O Estado de São Paulo foi pioneiro nessa área com a criação do Serviço Florestal em 1896.

O Parque Estadual Cantareira está situado na zona norte da cidade de São Paulo e ultrapassa os limites do município, atingindo trechos de Caieiras, Mairiporã e Guarulhos. Formou-se, entre o final do século XIX e início do seguinte, com a aquisição pelo Estado de várias áreas para a recuperação das matas devastadas pelas culturas do café, mate e cana-de-açúcar, e também para preservar as nascentes, visando garantir o abastecimento de água, cujo sistema foi iniciado em 1909.

Em 1963, a região da serra foi constituída como Reserva Florestal e, em 1986, como Parque Estadual da Cantareira, uma unidade de conservação, integrando-se à Reserva da Biosfera da Mata Atlântica da UNESCO em 1993. O Parque Estadual da Cantareira é de responsabilidade e domínio do Instituto

\footnotetext{
${ }^{31}$ Lei Municipal $n^{0} 7.733$ de 14 de outubro de 1998.

${ }^{32}$ Lei Municipal $n^{\circ} 8.881$ de 4 de outubro de 2006
} 
Florestal do Estado e, muito semelhante ao Pedroso, sofre a influência de um entorno populoso da região metropolitana de São Paulo, pois é cortado por quatro estradas asfaltadas: Rodovia Federal Fernão Dias (BR-381), Estrada Velha de Mairiporã, Estrada do Juqueri e a Estrada de Santa Inês, sendo esta última transitada por ônibus urbanos. Existem ainda outras estradas nos seus limites e internamente. A reserva contém redes de transmissão de eletricidade e os reservatórios de abastecimento de água. No Parque são desenvolvidos 0 ecoturismo e a pesquisa científica (São Paulo, 1974).

Segundo o SNUC, as unidades de conservação são definidas como áreas do território ou do mar brasileiro com características naturais relevantes, como ecossistemas únicos; recursos ambientais de valor cênico e paisagístico com limites demarcados e com objetivos de conservação.

A categoria de Parque Nacional prevê a preservação de ecossistemas naturais de grande relevância ecológica e beleza cênica; pesquisas científicas, atividades de educação e de turismo ecológico; visitação pública orientada de acordo com normas e restrições estabelecidas no Plano de Manejo da unidade. É necessário que a área seja de posse e domínio públicos, sendo este último um fator indispensável para a consolidação do Parque como unidade de conservação.

A obrigatoriedade das UCs e estações ecológicas constituírem áreas de domínio público decorre das rigorosas restrições legais ao uso dos recursos naturais. Com a abertura do SNUC, ampliou-se o número de categorias de UCs de domínio público, tornando-se uma situação comum, em todo território brasileiro, a criação de "unidades que não saíram do papel" pelas dificuldades encontradas na regularização fundiária com as irregularidades nas documentações e no registro da propriedade imobiliária (Costa Neto, 2006:29).

Cerca de $57 \%$ das unidades de conservação na esfera federal não possuem a situação fundiária regular. ${ }^{33} \mathrm{O}$ Parque do Pedroso não possui todo o mosaico de glebas em posse pública, muito embora a maior parte tenha sido desapropriada entre as décadas de 1960 a 1990.

O grupo de Unidades de Proteção Integral determina a preservação da natureza, sendo admitido apenas o uso indireto dos seus recursos naturais, “(...) com exceção dos casos previstos nesta Lei”. O uso indireto não envolve "(...) consumo, coleta dano ou destruição dos recursos naturais". ${ }^{44}$ As exceções

\footnotetext{
33 Pádua apud Costa Neto, op. cit.

34 Art. 2ำ IX, SNUC.
} 
previstas na Lei do SNUC não consideram o uso que se faz da água dos lagos represados do Pedroso para abastecimento público, mas é um caso muito semelhante a outras unidades de conservação, como o Parque da Cantareira. No Pedroso, a exploração da água teve início na década de 1940, portanto, anterior à instituição do Parque como unidade de conservação e da Lei do SNUC.

Por Plano de Manejo, entende-se "o projeto dinâmico que, utilizando técnicas de planejamento ecológico, determine o zoneamento de um Parque Estadual, caracterizando cada uma das suas zonas e propondo seu desenvolvimento físico, de acordo com suas finalidades." As características das zonas estão estabelecidas no Decreto Estadual que dispõe sobre o Regulamento dos Parques Estaduais Paulistas ( $n^{\circ} 25.341 / 1986$, art. $6^{\circ}$ e $7^{\circ}$ ) e, logicamente, esta definição não se aplica apenas aos Parques Estaduais.

O Parque do Pedroso ainda não possui seu plano de manejo e também não figura nas listagens oficiais de unidades de conservação. 


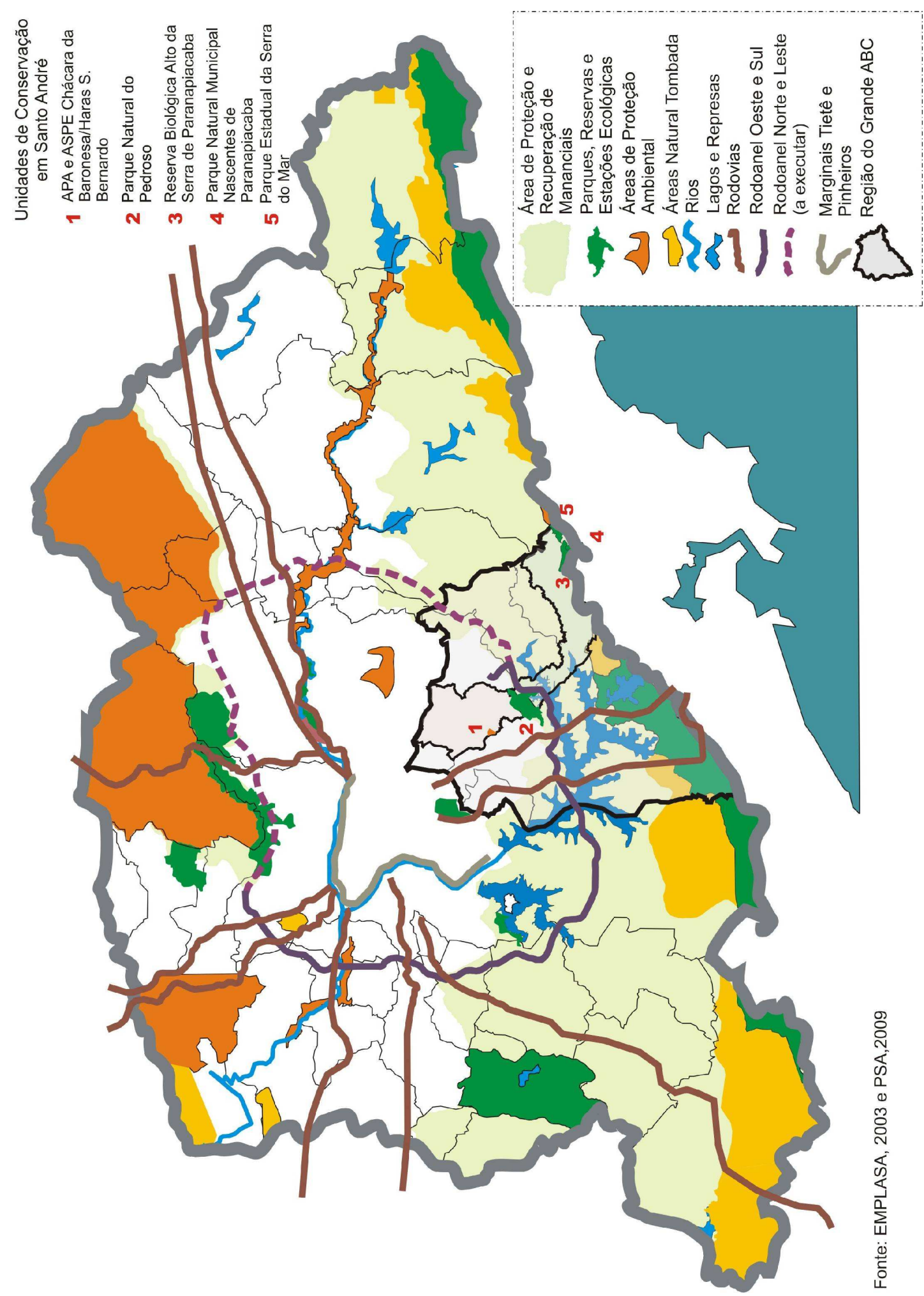

Figura 13: Unidades de Conservação na Região Metropolitana de São Paulo. Organização: Robson S. Moreno. 


\section{A população urbana e a unidade de conservação}

A transposição do modelo de parques nacionais para o Brasil ignorou as condições sócio-culturais completamente distintas das norte-americanas. A realidade comum em muitas unidades de conservação em todo território brasileiro é a existência de população moradora em seu interior (Oliveira, 1999).

No Parque do Pedroso, como já foi exposto no capítulo I, havia moradores vivendo há 40 anos na antiga Olaria, antes, portanto, da instituição da unidade de conservação.

A única forma de ocupação humana reconhecida pelos governos e pela legislação que disciplina as UCs, é a presença de populações tradicionais, definidas como:

"Comunidades tradicionais estão relacionadas com um tipo de organização econômica e social com reduzida acumulação de capital, não usando força de trabalho assalariado. Nela produtores independentes estão envolvidos em atividades econômicas de pequena escala, como agricultura e pesca, coleta e artesanato. Economicamente portanto, essas comunidades se baseiam no uso dos recursos naturais renováveis. (...)" (Diegues, op. cit.:87).

O SNUC prevê que essas populações devem ter garantias a subsistência e a possibilidade de uso sustentável dos recursos naturais (nos casos em que essas comunidades podem ser mantidas nas UCs.). Porém, desconsidera-se a população e a realidade urbana, como é explicitada no artigo 49 que dispõe que a "área de uma unidade de conservação do Grupo de Proteção Integral é considerada zona rural para efeitos legais e uma vez definida formalmente sua zona de amortecimento, não poderá ser transformada em zona urbana."

O não enfrentamento dessa interface com populações urbanas, que não é sequer tratado pela legislação, torna-se um problema tão ou mais intenso que o não enfrentamento da realidade de populações tradicionais que viviam nos territórios antes das instituições de preservação dos Parques ou Reservas. Trata-se de uma dificuldade associada à gestão dessas áreas pelos governos que "impõem sua política através de leis direcionadas exclusivamente à preservação da natureza, mas não ao homem integrado a ela" (Oliveira, op. cit.:74). 
A transformação da região de Santo André, que foi promovida pela alteração econômica de um padrão rural para um urbano-industrial, como já vimos, proporcionou o avanço da ocupação urbana em direção à área do Parque, somando 45.135 habitantes no limite norte (bairros Jardim Vila Rica; jardim Santo André; Vila João Ramalho e Cata Preta) e 23.291 habitantes no limite sul (glebas Waisberg I e II; Recreio da Borda do Campo; Parque Miami; Jardim Riviera; Parque do Pedroso e três Divisas), segundo o Censo de 2000 do IBGE (Santo André, 2008a).

Em uma ação muito recente do órgão gestor do Parque - SEMASA -, a população moradora de seu interior foi retirada e era caracterizada como um grupo essencialmente urbano, com hábitos e consumo urbanos, o que, segundo Santiago ${ }^{35}$, seria incompatível com a conservação da área. Isso, sem dúvida, ilustra essa discussão e demonstra também que o enfrentamento dessa realidade, segundo Oliveira (op.cit.), tanto pelos governos, quanto pelos técnicos, pressupõe que o desenvolvimento urbano e seus interesses econômicos contrariam a ideia da conservação de uma área "natural", nos moldes como a conservação é entendida hoje.

Esse privilégio da conservação da natureza apartada da sua realidade urbana não diminui a problemática, intensificando em grande medida essa tensão entre o Parque e a população ao precarizar a condição de vida desses moradores que, ao saírem do Parque, se deslocam para assentamentos precários próximos. ${ }^{36}$

Essa é uma questão que deverá ser enfrentada dada a tendência de intensificação da problemática, uma vez que as projeções nada animadoras da Organização das Nações Unidas (ONU) indicam um crescimento urbano para as próximas décadas que deve atingir 59,7\% em 2030 e 69,6\% em 2050. Nos anos de 2007 e 2008, pela primeira vez na história, a população urbana superou a que vive em áreas rurais, com cerca de 3,3 bilhões de pessoas morando em cidades (Golub, op. cit.:6).

\footnotetext{
${ }^{35}$ Depoimento Cristina M. Santiago, op.cit.

${ }^{36}$ Foi o caso de alguns ex-moradores da Olaria que, depois de aproximadamente 40 anos residindo no Parque, após a desocupação (e indenização) promovida pelo SEMASA/DERSA, mudaram-se para o Núcleo Toledana, um assentamento precário, lindeiro ao Pedroso.
} 


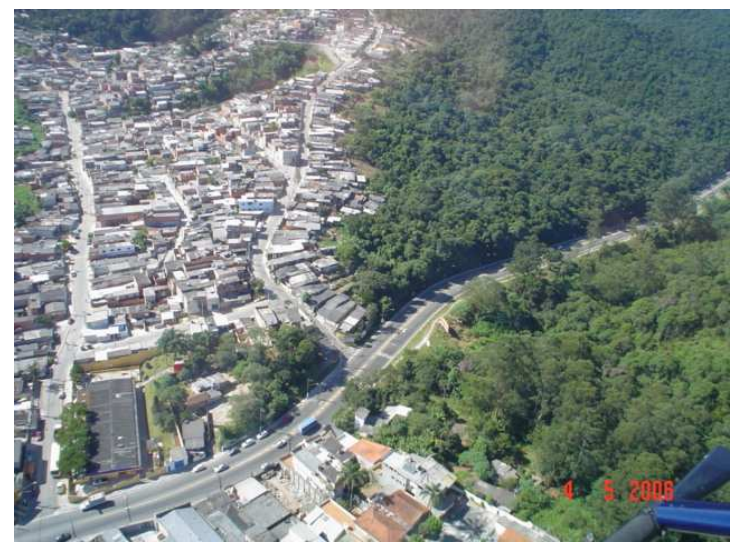

24. Estrada do Pedroso. Limite com área urbana (Norte). Fonte: DGA, SEMASA, 2006.

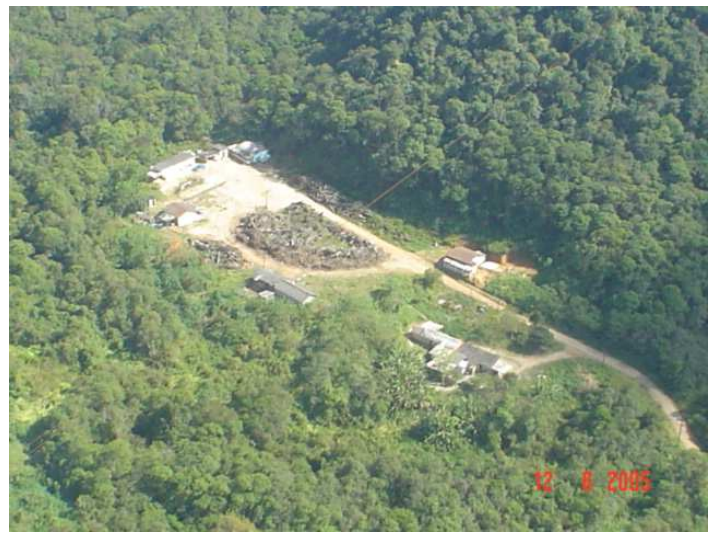

26. Local da antiga Olaria, moravam 17 famílias, que foram retiradas para dar lugar a um viveiro de mudas nativas.

Fonte: DGA, Semasa, 2005.

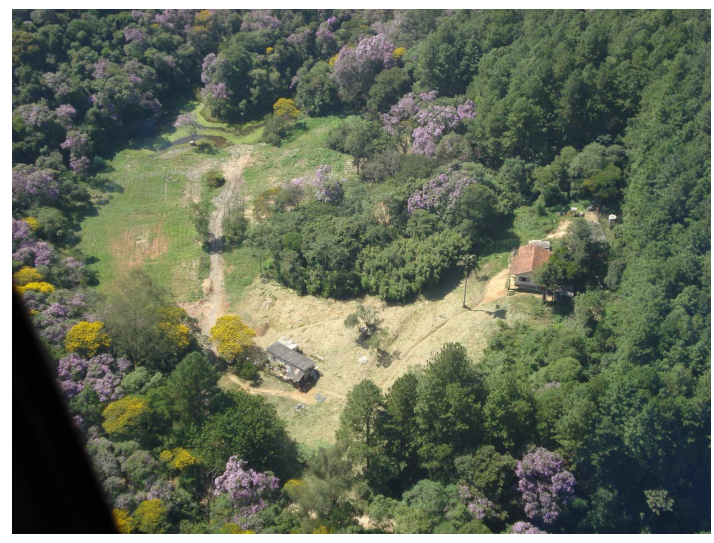

28. Antigo Haras. Estrada do Montanhão, $\mathrm{n}^{\circ} 115$

Fonte: DGA, Semasa, 2008

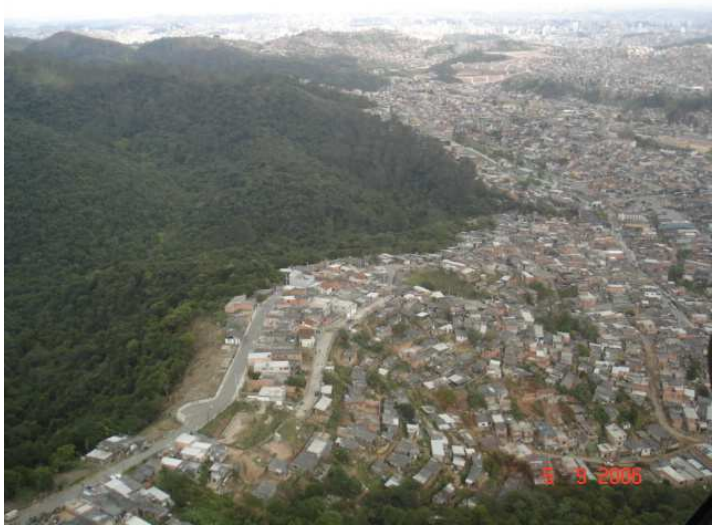

25. Divisa com o Núcleo Toledana (Leste).

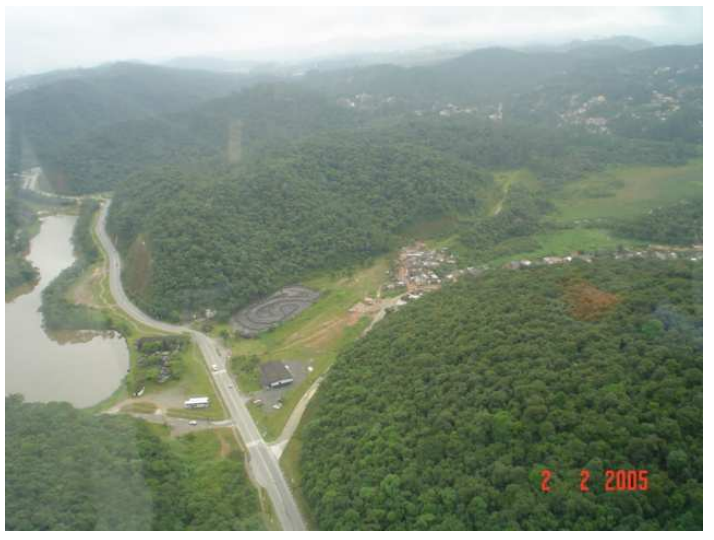

27. Núcleo Pintassilgo, antigo Kart, grupamento ecológico e Marquise, Estação A do teleférico.

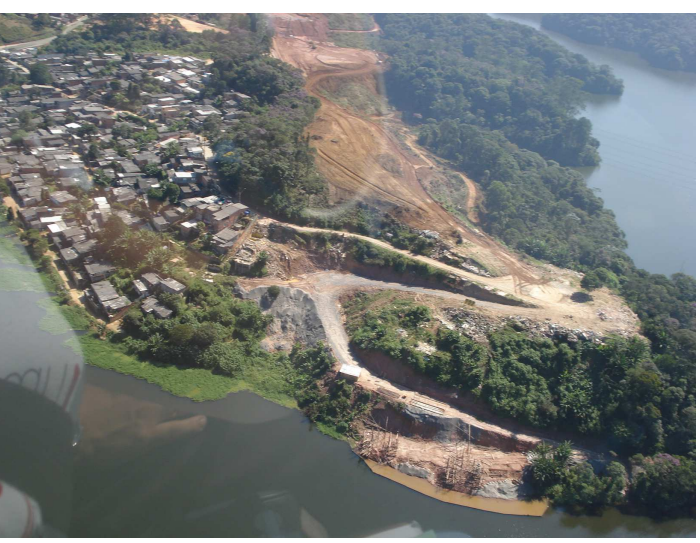

29. Implantação do Rodoanel e Núcleo Pintassilgo. 
A intervenção recente do Rodoanel, sem dúvida alguma, supera qualquer impacto que uma comunidade de 57 pessoas (tomando o maior número de exmoradores) pudesse proporcionar ao Parque. O impacto foi de tal magnitude que poderá comprometer a manutenção da biodiversidade, pois a única ligação que permitia um fluxo gênico com a porção sul do município foi rompida. Nessa região concentram-se as áreas florestadas que configuram a Área de Proteção de Mananciais, Parque Nascentes de Paranapiacaba, Reserva Biológica Alto da Serra de Paranapiacaba e o Parque Estadual da Serra do Mar.

A obra rodoviária foi consentida e legitimada pelo Estado, cumprindo todas as normas e procedimentos legais com os devidos Estudos e Relatórios de Impactos Ambientais. Vê-se, portanto, que o estabelecimento do valor que representa para a sociedade, tanto a obra do Rodoanel quanto a manutenção do corredor biológico, essencial ao Parque e a população moradora, atendem aos interesses dominantes, de acordo com a compreensão temporária que se tem desses valores. As leis, portanto, cumprem um papel ideológico:

"O grande instrumento do Estado é o direito, isto é, o estabelecimento das leis que regulam as relações sociais em proveito dos dominantes. Através do direito o Estado aparece como legal, ou seja, como 'Estado de direito'. O papel do Direito ou das leis é o de fazer com que a dominação não seja tida como uma violência, mas como legal, e por ser legal e não violenta deve ser aceita. A lei de direito para o dominante e dever para o dominado. Ora, se o Estado e o Direito fossem percebidos nessa sua realidade real, isto é, como instrumentos para o exercício consentido da violência, evidentemente ambos não seriam respeitados e os dominados se revoltariam. A função da ideologia consiste em impedir essa revolta fazendo com que o legal apareça para os homens como legítimo, isto é, como justo e bom. Assim, a ideologia substitui a realidade do Estado pela idéia do estado - ou seja, a dominação de uma classe é substituída pela idéia de interesse geral encarnado pelo Estado" apud Oliveira (op. cit.:114).

Se considerarmos a proposta do Rodoanel como um fato que atende a um modelo de transporte que vigora e privilegia o trânsito rodoviário de cargas e de passeio individuais em detrimento a um modelo coletivo e menos impactante 
ambientalmente, visto isso pelo foco da conservação do Parque do Pedroso, ainda assim, o que devemos considerar, é que havia outra opção de implantação, ao norte, no limite da Macrozona Urbana, que implicaria em maiores custos de desapropriações de moradias, porém, sem impactar tanto o Parque, ou ainda, outros recursos da engenharia, como viadutos que não foram executados.

Essa desproporção de impactos entre a obra rodoviária e a manutenção das moradias no interior do Parque é algo que merece uma discussão mais ampla e acurada, avaliando se esse modelo de conservação realmente atinge os objetivos a que se propõe.

Nesse sentido, compartilhamos do que diz Oliveira (op. cit.:114): "a instituição de unidades de conservação, em si, não constitui o meio de preservação ou conservação, assim como, a implementação de leis e, até mesmo a proposta de plano de manejo, como modelo de gestão, deve ser discutida em sua forma e eficácia." 


\section{As várias visões sobre o Parque do Pedroso}

Uma parte da pesquisa foi dedicada a colher depoimentos, no intuito de acrescentar ao trabalho algumas opiniões e visões particulares de diferentes atores sociais que tivessem ligações e experiências variadas com a unidade de conservação, e também com o objetivo de completar a análise sobre o Parque do Pedroso, através da noção de paisagem, reunindo os aspectos sociais e os naturais.

O enfoque da paisagem abriu um leque de abordagens possíveis, explicitando a complexidade do tema e envolvendo uma delicada, quase sempre tensa, contraditória e dependente relação entre o homem e a natureza.

Foram duas técnicas aplicadas: uma individual por entrevistas depoimentos orais, através de uma pesquisa qualitativa - e outra coletiva, com a realização de uma oficina de Biomapa pela Gerência de Educação e Mobilização Ambiental do SEMASA, que foi elaborada (metodologicamente) por essa mestranda que escreve.

Como um exercício, objetivando expor as variadas formas de perceber a paisagem do Parque do Pedroso, traçou-se um paralelo entre as paisagens de Meining (1979) com o texto "O Olhar. Dez versões da mesma cena" (The beholding eye. Ten versions of the same scene) e as falas dos seis entrevistados, revelando a posição (desse grupo pequeno) e dos gestores públicos de uma maneira geral. Algumas falas se enquadraram em uma ou mais formas de entender a paisagem.

No referido texto, Meining descreve a diversidade de interpretações de uma mesma paisagem, num mesmo momento, observada por um grupo pequeno e variado.

Para os que descrevem a paisagem como natureza há a tendência de retirar o homem da cena para restaurar uma natureza na sua condição primitiva. Diante do poder da natureza, o homem é pequeno, superficial, efêmero e subordinado e todas as grandes obras dos homens são transitórias.

Um sentimento nostálgico de uma ideia de região selvagem envolve essa percepção da paisagem e teve grande difusão no Romantismo do século XVIII, onde preponderava a visão de uma natureza pura, boa, de grande beleza. Seu principal impacto aconteceu sobre a ciência do século XIX que adotou o termo "ciência natural". 
Essa visão está presente nas bases da concepção norte-americana de proteção das áreas naturais selvagens por meio da criação de parques nacionais que deveriam estar livres da presença humana e que, a priori, exerceria uma influência nociva à natureza. No Brasil, a tradução mais recente desta ideia de proteção foi aplicada ao Parque do Pedroso e realizada pelo SNUC, que estabeleceu as categorias de proteção e normas. Enfim, arcabouço legal que regula as unidades de conservação. Essa postura do SNUC ratifica o já exposto no trabalho.

Retirar o homem da cena se expressou em falas como a de Aminadabe (2009), com base na experiência vivenciada pela fiscalização realizada no Parque com os ex-moradores: “(...) o relacionamento daquelas pessoas com o Parque era de degradação. (...) caçavam, destruíam, juntavam-se com pessoas para caçar Tatus para vender". Certamente, com base nessa experiência e na aplicação da Lei (SNUC), a população moradora das áreas internas ao Parque foi retirada em uma ação recente do SEMASA, patrocinada financeiramente pela DERSA como compensação aos impactos promovidos pela implantação do Rodoanel.

Paisagem como habitat, traduz a visão dos que encaram toda a paisagem como um pedaço da terra para a "Casa do Homem". Há um trabalho contínuo de adaptação para tornar viável a relação com a natureza, com alterações para torná-la produtiva, utilizando seus recursos para diversos fins. Em resumo, é o homem "domesticando" a terra. Toda a paisagem é basicamente uma interação do homem e a natureza que é generosa. Todo o trabalho é em direção a uma simbiose, um processo pelo qual o homem tem se dedicado há milhões de anos.

O conceito geral ainda está vivo e aparece sob várias formas dentro da literatura mais recente sobre ecologia e meio ambiente.

Num período de aproximadamente 16 anos, a experiência de D. Maria e $\mathrm{Sr}$ Miguel Pastor (2009), como moradores do Parque, demonstra que a relação criada por eles aproxima-se desta forma de ver a paisagem, descrita por Meining. A natureza do Parque proporcionou o trabalho e o alimento pelo peixe e pelas frutas. Já, o cuidado e afeto que se desenvolveu a partir dessa vivência cotidiana, foi o reconhecimento dessa natureza como "um paraíso" que deve ser utilizado e cuidado. “(...) se não cuidar, não tem." Essa visão aproxima-se também, da percepção da paisagem como lugar. 
As pessoas que veem a paisagem como artefato encontram a marca do homem em tudo e em todos os lugares.

O solo, árvores e rios não são 'naturezas' tão evidentes, mas criações humanas que se transformam em solos alterados pelo cultivo, pela produção, pelo uso de fertilizantes, pelo aquecimento da temperatura com as descargas químicas no ar, pelas drenagens, assoreamento e canalizações dos rios, afetando seu regime natural e atingindo suas bacias por meio de desmatamentos, queimadas e todo um complexo de mudanças causadas por novas associações de espécies.

O papel do homem tem sido tão poderoso nas mudanças da face da terra, que toda a paisagem tornou-se um artefato. A ciência é marcada pelo reconhecimento do homem como ecologicamente dominante e é concomitante com o crescimento do poder persuasivo da engenharia para a alteração física da terra e da biologia para alterar a vida orgânica.

A apropriação da natureza pela exploração da floresta por meio de uma visão utilitarista a serviço de um processo produtivo marcou a história de Santo André e região, não se mostrando diferente na história do Brasil e do mundo. Os limites de exploração foram sendo estabelecidos quando esta exploração passou a ameaçar os mananciais de água de abastecimento da cidade e região, criando a necessidade de salvaguardá-los por instrumentos legais, por meio do Decreto que promoveu as primeiras desapropriações para captação das águas do ribeirão Pedroso e das áreas de mananciais. Entre uma contradição ou coerência de uma sociedade baseada na visão da natureza como um artefato, a conservação do Parque também foi motivada pelo valor econômico do recurso natural que representava a floresta: a produção de água.

A preservação do Parque foi assegurada por lei, mas esta proteção legal não foi capaz de frear ou inverter a relação que as forças econômicas exercem em nossa sociedade, se considerarmos a grande intervenção recente, causada com a implantação do Rodoanel Metropolitano.

Essa paisagem é um artefato para os gestores públicos que encaram áreas "naturais", como as do Parque do Pedroso, como bens de capacidade infinita de regeneração frente às necessidades de desenvolvimento sócioeconômico dadas as constantes fragmentações e alterações a que essa mata e o conjunto que compreende esse ecossistema esteve recentemente sujeito, devido à implantação 
da rodovia (Rodoanel Metropolitano) - e estará futuramente, cedendo seu espaço às redes de energia elétrica.

Para a paisagem como sistema, a terra, as árvores, rodovias, construções, e os homens são vistos não como objetos, mas como partes de um conjunto de variados elementos ou classes de fenômenos, partes de processos fundamentais. Tal como pensar em um rio não como um rio, mas como um elo no circuito hidrológico.

A paisagem é um equilíbrio dinâmico de processos interagindo entre si. $\mathrm{O}$ homem é claramente uma parte inexorável desse sistema, de uma maneira ou de outra, e deverá entender antes todo o estado da paisagem. A ciência está a serviço da compreensão mais profunda dessas inter-relações.

A coerência mencionada na paisagem como artefato está, tanto no reconhecimento da necessidade da conservação do recurso natural essencial à vida humana, compreendendo a dinâmica natural que o envolve, quanto na lógica capitalista de uso dos recursos naturais em benefício da sociedade. A compreensão da importância dos mecanismos que envolvem a manutenção da água, levando a proteção da floresta em torno de uma bacia hidrográfica (subbacia) inteira, foi o resultado de pensar a paisagem como sistema e, sem dúvida, foi vislumbrada na iniciativa do município e dos gestores públicos, em meados da década de 1940, ao promoverem a primeira leva de desapropriações de terras visando a proteção do manancial de água que oferecia o ribeirão Pedroso. Segundo Cristina M.Santiago (2009), "foi uma atitude visionária" por ter sido uma iniciativa municipal.

$\mathrm{Na}$ paisagem como um problema, os campos estão erodidos, os rios transbordando, as florestas destruídas, árvores morrendo, fazendas dilapidadas, há poluição industrial, expansão urbana, lixo e, no meio disso tudo, pessoas empobrecidas de corpo e espírito.

Toda a paisagem evoca indignação e alarme, é um espelho da doença de nossa sociedade que espera por uma mudança.

A interface do Parque com a área urbana e seu contingente populacional é vista pelos gestores públicos como um problema para a conservação do Pedroso. Há um desamparo legal para o enfrentamento desse conflito, sendo que a legislação privilegia a preservação da natureza em detrimento das populações, 
principalmente urbanas, não havendo um direcionamento para se trabalhar a conservação de forma integrada com as comunidades.

Um grande instrumento para superação dessa tensão pelo contato com a área urbana e sua população está na educação e no uso conduzido e orientado da área de uso intensivo. A vocação do Pedroso para o lazer, que foi construída historicamente e que hoje se manifesta como uma demanda de um entorno populoso, foi mencionada no depoimento de Luis H. R. Zanetta (2010): "ele [Parque do Pedroso] tem a interface com uma população muito numerosa dos bairros Miami, Jardim Irene, e todo mundo que está ali em volta quer ter uma boa opção de lazer, então essa vocação (...)."

A educação usada como método de superação de um Parque que "é tido como coisa do 'povão lá do fundo', um lugar que os moradores do centro não vão visitar", foi apontada no depoimento de Raul Pereira (2009), como uma forma de aproximação da população moradora do centro de Santo André para superar uma dicotomia. A educação interativa em um processo via internet - articulado com as redes de educação pública e privada - seria um vetor de aproximação, de superação das distâncias e preconceitos de atração ao Parque, sendo que este papel, no passado, prestava-se ao Teleférico. "Além dos belos atrativos e das atividades culturais que o Parque oferece, passaria a funcionar como um pólo conectado com a rede escolar, dentro de uma programação e agendamento, o que o tornaria um elemento vivo e dinâmico para a cidade."

Um dos objetivos da categoria parque é a educação ambiental e, segundo Cristina M. Santiago (2009), não apenas uma cartilha, mas um trabalho contínuo, o que é diferente de informar, como foi o Programa de Jovens. ${ }^{37}$ "(...) esse é o trabalho que realmente vale e fica." Cristina fez referência à população moradora do interior e do entorno do Parque.

As pessoas que veem a paisagem como riqueza, costumam olhar toda a cena, fixando um valor econômico para todas as coisas a sua vista. Em tal visão, a paisagem tem seu futuro orientado de acordo com os valores de mercado e é sempre submetida às mudanças e tendências de uma sociedade que é fortemente comercial, dinâmica, pragmática e com pensamento quantitativo.

\footnotetext{
${ }^{37}$ PJ - Programa de Jovens - Programa Reserva da Biosfera, ligado à Unesco e promovido pelo Instituto Florestal, em parceria com municípios. O programa de Jovens iniciou em 2002 e agregava jovens de 14 a 20 anos que viviam no entorno do Parque do Pedroso e era administrado pelo DGA do SEMASA (Diário, 2005;GEMA, 2010).
} 
Esta forma de encarar a paisagem, como está fortemente calcada na ideologia norte-americana, é reflexo de valores culturais e representa a aceitação da ideia de que a terra e seus recursos são, primeiramente, uma forma de capital e, secundariamente, a morada ou herança familiar.

Dentro da lógica capitalista, o uso dos recursos naturais, inicialmente pela exploração da mata de forma extrativista, foi, posteriormente, um fator para sua conservação, originado pela necessidade do uso da água para abastecimento da população não mais de forma extrativista, mas sustentável, conservando a floresta produtora dos mananciais desse recurso natural.

Paisagem como ideologia. Da mesma forma como os cientistas olham através da superfície os elementos óbvios e vêem processos em operação, também outros podem ver esses mesmos elementos chave e toda a cena como um símbolo de valor, domínio de ideias, fundamentando filosofias de uma cultura.

Aqueles que veem a paisagem como uma ideologia podem ver manifestações distintas das interpretações norte-americanas de liberdade, individualismo, competição, utilidade, poder, modernidade e progresso. É uma visão que claramente insiste que se nós quisermos mudar a paisagem, teremos que mudar as ideias que criamos e mantemos sobre o que nós vemos.

Há dois pólos ideológicos que podemos associar ao Pedroso. Dos biólogos e ambientalistas que têm nessa natureza um valor em si de manutenção da vida, cujas razões de sua preservação sobrepujam qualquer outra ação ou uso. Neste caso, sua violação é contra a vida presente nesse ecossistema e contra o planeta.

O outro pólo é a paisagem vista como recurso natural, de forma utilitária a serviço do homem. Sua violação é inevitável e toda a ação neste sentido se justifica pelo benefício à sociedade e há uma desproporção no dimensionamento deste "benefício" em detrimento aos danos e consequências. O Rodoanel Metropolitano é uma tradução desse modo de pensar.

Para as pessoas que veem a paisagem como história, o que se mantém na frente de seus olhos é uma profunda recordação, complexa e cumulativa dentro da história natural e geológica. O principal sistema de organização é a cronologia, mas a história não está na pessoa, e sim no andaime sobre o qual se constrói a história. 
A terra é um enorme e rico depósito de fatos sobre as pessoas e sociedades, mas tais fatos devem ser colocados no contexto histórico apropriado para serem interpretados corretamente. Segundo a visão histórica, a paisagem provê infinitas possibilidades.

As infinitas possibilidades se expõem nas falas de todos os entrevistados. Através da história do Parque do Pedroso temos o testemunho do desenvolvimento sócioeconômico de Santo André e região. Inicialmente, o relato aparece por meio da apropriação econômica que se fez dessa área e, num segundo momento, no desenvolvimento político-ambiental, particularmente da cidade de Santo André. Esse último aspecto mostra certo "pioneirismo" expresso nas políticas públicas que fez desta cidade uma referência nessa área. A preservação dos mananciais do ribeirão Pedroso e, posteriormente, a instituição do Parque como uma unidade de conservação, como já foi mencionado, foi encarada como uma "atitude visionária".

Outro aspecto levantado por Raul Pereira (2009) foi o "rompimento com a história do Parque", em referência às três estações teleféricas desativadas e abandonadas na década de 1990, sem atribuição de um novo uso, “(...) é como se fosse acabando com a história lentamente, é como se 'cortasse com um facão', um pedaço importante do Parque."

"A história do Santuário é também a história da Federação Umbandista do $A B C$ ". Com esta frase, Ronaldo Antonio Linares (2009) inicia o relato sobre o Santuário Ecológico da Umbanda, que já utilizava o espaço no Parque do Pedroso informalmente desde a década de 1960, e, mais tarde, se tornaria uma concessão pública de uso. A legitimidade da utilização daquela área dentro da unidade de conservação sob o ponto de vista religioso está vinculada ao desenrolar da história do surgimento do Umbandismo no Brasil: "O Umbandista tem por altar a natureza, antes de mais nada."

Esse relato também descreve o funcionamento da Pedreira Montanhão e, brevemente, o contexto econômico do período desenvolvimentista no Brasil, incentivando a vinda das indústrias automobilísticas para a região.

Paisagem como lugar. Nesta visão toda paisagem é uma localidade, um pedaço individual no mosaico infinitamente variado da terra. É a paisagem como meio ambiente, abarcando tudo o que vivemos no nosso meio e, desta forma, cultivando a sensibilidade para detalhes, para textura, cores de todas as nuances 
da relação visual e mais: concentrando todos os nossos sentidos e o sentimento do lugar como um bem.

O geógrafo estuda as características dos lugares. Composições têm forma e o geógrafo verá na paisagem uma variedade de padrões artificiais, relações, aglomerados, inclinações, dispersões, gradações e misturas. Isto é claro, adquire significado quando interpretado com alguns entendimentos da história e ideologia de processos, funções e comportamentos do grande contexto geográfico. O historiador pode ter seu interesse também na mesma direção, através da generalização ou particularidade. Aqueles interessados nas particularidades das localidades acreditam que uma das grandes riquezas da terra é a imensa variedade de lugares.

O sentimento do lugar como um bem e de pertencimento esteve presente na fala de alguns dos entrevistados:

"É uma área significativa, rica, relativamente preservada, uma preciosidade (...)."

“(..) aquela área, perto da igreja, que é uma das mais preciosas. (...) "(Raul I. Pereira, 2009)

“(...) é realmente um paraíso (...)” (Miguel e Maria B. Pastor, 2009)

"O Parque do Pedroso é uma área que, não só eu, mas todo o município de Santo André deveria cuidar com carinho, porque é o único pulmão que a cidade ainda tem dentro da área urbana. (...) o Parque do Pedroso é o Amazonas [sic] Amazônia de Santo André que precisamos tomar conta, preservar. É uma área muito bonita (...) Ele é uma coisa que já faz parte de mim.” (Aminadabe B. Florêncio, 2009).

"Para nós, o Santuário no Parque do Pedroso, acabou encerrando a célula definitiva da Umbanda.(...) A área era nossa. Quem fez fomos nós. (...) ter um espaço onde nós pudéssemos praticar nosso rito" (Reinaldo A. Linares, 2009)

Paisagem como estética. Nesta visão, interessa menos a identidade e função de feições geográficas específicas do que a preocupação com suas qualidades estéticas. "Qualidade estética” é uma eterna matéria controversa. 
Dentro da área da pintura da paisagem nós encontraremos exemplares que expressam muitas visões de paisagem discutidas: o poder e majestade da natureza, a harmonia do homem e a natureza, a marca da história sobre a terra, o detalhado caráter dos lugares. A procura por um significado que não é explícito nas formas originais.

A paisagem é um modo de ver e tais paisagens falam muito sobre os valores que as sociedades mantêm (não só a americana), e falam sobre as visões de mundo provisórias que refletem na qualidade de vida que levamos. As dez paisagens não esgotam as possibilidades de tais cenas, mas elas sugerem a complexidade do tema. 


\section{Pesquisa Qualitativa individual - Depoimentos Orais}

O uso de fontes orais como técnica de apreensão social é um instrumento de pesquisa da Sociologia desde o século XIX. Esse tipo de pesquisa teve avanço a partir da Segunda Guerra Mundial, fruto da ampliação do poder dos Estados no período da crescente industrialização, cujos objetivos eram entender, organizar, regular e controlar a população (Minayo, 1992).

Dentre as técnicas desenvolvidas, há a pesquisa quantitativa onde os fenômenos sociais são estudados por meio de equações, médias, gráficos e estatísticas. Quando a pesquisa se abre para o campo de significações, motivos, aspirações, atitudes, crenças e valores que não podem ser traduzidos em números (ou mensurados), a pesquisa qualitativa é mais adequada. Utilizando-se de outros referenciais de coleta e interpretação, a técnica da pesquisa qualitativa procura organizar o conteúdo discursivo sob a forma descritiva. As duas técnicas (qualitativa e quantitativa) se complementam (Minayo, op.cit.).

Segundo Gurvitch, a "(..) realidade tem camadas e a grande tarefa do pesquisador é de apreender além do visível, do morfológico e do ecológico". Esse autor denomina a região mais visível dos fenômenos sociais como "morfológica, ecológica, área concreta" apud Minayo (op.cit.:22).

Para as Ciências Sociais o "objeto" é histórico. Isso significa dizer que as sociedades humanas desenvolvem-se num determinado espaço e tempo, com visões de mundo provisórias. Essa forma de encarar os fenômenos sociais aproxima-se da disciplina de História, que passou a se utilizar dessas práticas sociológicas (também literárias, psicológicas, antropológicas e jornalísticas) como fontes de pesquisa e informação sob a denominação de História Oral, a partir das décadas de 70 e 80 . Sua utilização teve avanço quando foram valorizadas temáticas da chamada "História vista de baixo" ou sob o ponto de vista dos dominados: mulheres ou minorias, bem como temáticas sobre cultura popular, sua produção e presença na sociedade de massas (Fenelon, 1996).

A História Oral passou a ser praticada por diversas áreas do conhecimento sob óticas variadas, sendo assim, difícil defini-la (Lang, 1996). A particularidade, o elemento fundamental e característico da História Oral quando comparada a pesquisa qualitativa, é a memória. Através do resgate da memória é que se expõe a informação, mas Meihy (1996) observa que História Oral não é memória, e sim um instrumento. 
As fontes orais pesquisadas neste trabalho foram qualificadas como depoimentos orais, utilizando a classificação de Lang (op.cit.). Foram seis entrevistados entre os anos de 2009 e 2010 e o conteúdo destas entrevistas, considerado relevante, foi incorporado ao texto nos capítulos. A íntegra das entrevistas se apresenta anexa. 


\section{Pesquisa coletiva - Biomapa}

O Biomapa - Mapeamento biorregional participativo, dentre os inúmeros outros instrumentos de participação comunitária em diagnósticos, elaborações e aplicação de projetos e programas - oferece a possibilidade de ser aplicado coletivamente para diversas finalidades.

A cidade de Santo André possui experiências de aplicação da técnica do Biomapa, fruto de uma "troca de experiências" propiciadas pelo Gerenciamento Participativo em Áreas de Mananciais (GEPAM) - um projeto de cooperação internacional realizado pela Prefeitura de Santo André, Universidade de São Paulo, e instituições canadenses, como a Universidade da Colúmbia Britânica (UBC) e a Agência de Cooperação Internacional Canadense (CIDA) - foi especialmente aplicado nas Áreas de Proteção e Recuperação de Mananciais (APRM) do município (Santo André, 2005).

A elaboração de um biomapa é um processo de realização de uma representação gráfica, geralmente em uma superfície plana e em determinada escala das características naturais e artificiais de uma determinada localidade. Entretanto, cabe ressaltar que esse processo rompe com uma característica: da centralidade técnica determinando essa representação. Segundo Harvey (1996), a elaboração de um mapa de uma determinada localidade é um exercício de dominação. Ele também nomeia como "cartografia da resistência" ${ }^{38}$ o exercício de fazer tal representação pelos segmentos da sociedade que geralmente são excluídos, como mulheres, idosos e crianças.

Assim, a elaboração de um mapa de determinada região, a partir do qual são feitos inventários biofísico, social, cultural e econômico, pode servir para uma agenda de planejamento e de desenvolvimento comunitário, além de outras finalidades. Essa técnica considera o entorno, sua cultura e economia com a necessária participação da comunidade local, traduzindo-se na construção de um mapeamento biorregional participativo. Assim, o mapeamento é constituído a partir da leitura que a própria comunidade tem do local em que se encontra. Esse processo tem como base as teorias dos planejamentos comunitários e biorregional.

\footnotetext{
38 "Cartografia da resistência" é o ato de confrontação com a representação de um mesmo sítio em percepções diferenciadas do espaço e tempo pelas populações "dominadas" como: crianças, jovens, idosos, nativos (Harvey, 1996).
} 
A oficina foi realizada em 21 de agosto de 2010, no Centro Educacional de Santo André (CESA Cata Preta) e aplicada pela Gerência de Educação e Mobilização Ambiental do SEMASA. Contou também com a participação de cinco educadores e quinze participantes dos bairros Recreio da Borda do Campo, do núcleo Pintassilgo, Jardim Irene, Vila Floresta e São Bernardo do Campo.

Formaram-se três grupos com a proposta de trabalharem sobre três temas: biofísico, histórico e conflitos. O resultado após o exercício de mapeamento, que foi exposto para o grupo geral, trouxe sobre o primeiro tema uma identificação dos equipamentos existentes no período em que foi implantado o parque de lazer. Houve um problema na condução deste tema por parte dos técnicos, já que a proposta era produzir um mapa de identificação dos elementos naturais do Parque. De qualquer maneira, ficou evidente que aquele grupo reconhecia a ausência dos equipamentos que já existiram no passado (teleférico, os pedalinhos e o minizoológico) como algo que hoje é inviável economicamente.

O tema do mapeamento no segundo grupo foi história e o foco foram as pessoas que moraram no interior do Parque, assim como os equipamentos que atendiam aqueles moradores e a população do entorno. Um bom exemplo são as pequenas escolas existentes ao longo da Estrada do Pedroso, na parte norte, próximas à divisa com a área urbana, aproximadamente no local da sede atual da Guarda Municipal.

Esse mapeamento localizou as moradias descritas no depoimento de Maria B. Pastor (2009), uma vez que ela foi uma das participantes deste grupo do biomapa.

O terceiro grupo levantou problemas referentes ao esgoto doméstico que é jogado in natura na Represa Billings, o desmatamento, o desaparecimento de nascentes, os pontos de acúmulo de lixo e os incêndios provocados. Com a perda do habitat devido ao desmatamento, muitas espécies de animais passam a procurar alimento próximo às residências, no lixo doméstico.

Os resultados mostraram que os problemas da falta de recursos para atendimento das demandas de funcionamento do Parque e os conflitos decorrentes da falta de conhecimento da importância do Parque do Pedroso precisam ser divulgados e mais informados para mostrar que o Parque é muito além de uma 'grande churrasqueira'. 
Com o fechamento da Estrada do Montanhão (acesso à São Bernardo) a segurança melhorou, diminuíram os pontos de descarte de resíduos sólidos ao longo da estrada, além dos cadáveres que eram encontrados frequentemente.

A avaliação desse exercício pela GEMA levantou algumas deficiências metodológicas e práticas, tanto na

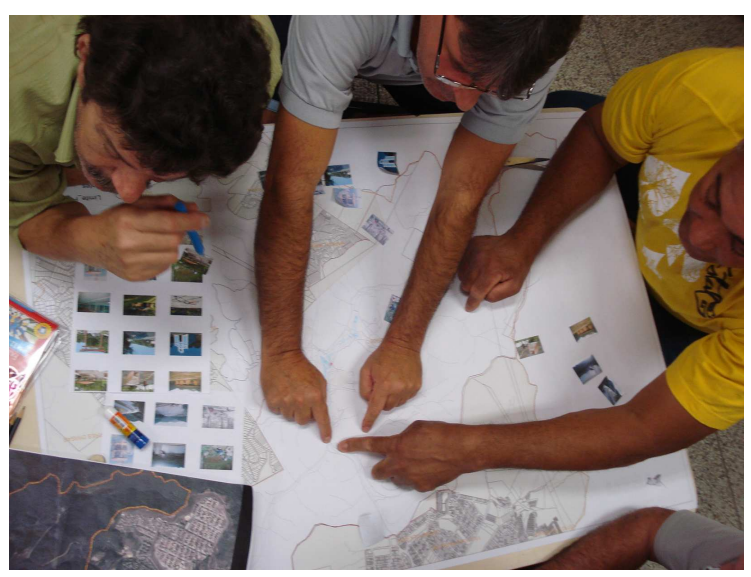

30. Oficina de biomapa. Fonte : DGA, SEMASA, 2010. preparação dos técnicos participantes para condução dos grupos e no tempo curto para o mapeamento, quanto na necessidade da convocação das pessoas em um prazo mais adequado, o que inviabilizou a participação de lideranças importantes dos bairros. A oficina mostrou-se uma ferramenta de atividade educativa, de diagnóstico do público participante ${ }^{39}$ e a

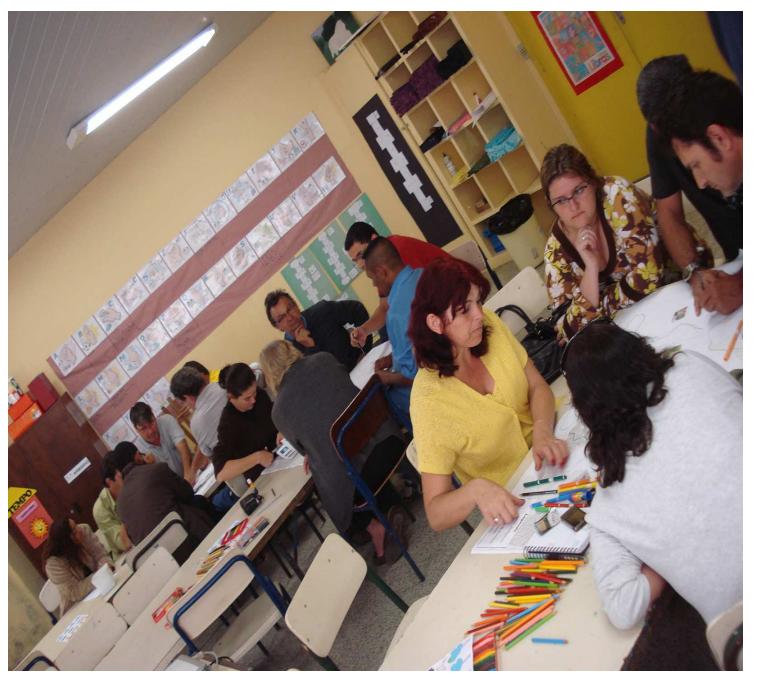
necessidade de continuidade da oficin: 31. Oficina de biomapa. Fonte : DGA, SEMASA, 2010. levantando-se a possibilidade de realizá-la dentro do Parque, no Recanto Arco Íris.

Para esta pesquisa, a oficina foi uma oportunidade de "escutar" um número maior de participantes de forma coletiva, ou seja, os moradores dos bairros do entorno do Parque do Pedroso que ainda não estavam representados nos depoimentos. É importante ressaltar que essa amostragem não representa a comunidade dos bairros como um todo, apenas a visão desse grupo particular.

Não seria "ambientalmente correto e socialmente justo" não abarcar a percepção e o conhecimento das pessoas no caso do Pedroso. Há os saberes de vida que os gestores públicos, técnicos e os teóricos desconhecem e deles não podem prescindir se, efetivamente, desejam compreender a complexidade das relações implícitas nas transformações da paisagem do Parque com vistas à

\footnotetext{
${ }^{39}$ GEMA. Relatório do programa Municipal de Educação Ambiental, 2010.
} 
criação de planos e projetos mais responsivos e processos de gestão mais democráticos no tempo e espaço. 


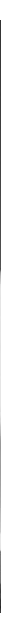

\section{Considerações \\ Finais}




\section{Considerações finais}

O "surgimento" do Parque do Pedroso como unidade de conservação com o objetivo de oferecer maior proteção a essa área natural estratégica, significativa, atendeu a uma realidade e uma necessidade contemporâneas diante da histórica exploração das matas, das transformações nos ecossistemas e da forte pressão exercida pelo avanço urbano.

A instituição da unidade de conservação de proteção integral, na categoria de Parque Natural Municipal, implica na obrigação do domínio público das glebas, e objetiva garantir a conservação dos ecossistemas controlada pelo Estado (no caso, pelo Município), que no Pedroso originou-se em torno da necessidade da água.

A conservação do manancial pelo município na década de 1940 tinha como exemplo outros casos semelhantes, como a Serra da Cantareira e a Floresta da Tijuca (mais remotamente), como uma experiência de reflorestamento voltada para a recuperação dos mananciais. Com a iniciativa do Pedroso, coloca-se em questão certo pioneirismo operado nessa esfera de gestão pública - municipal -, compreendendo a dinâmica natural que envolve a produção hídrica e sua dependência da floresta, preservando a capacidade de armazenamento de água e a recarga dos mananciais.

Essa compreensão, no entanto, não foi tão altruísta assim. A motivação tanto para a preservação deste recurso natural (água), objetivando seu uso, quanto para a exploração dos recursos da floresta no passado, são reflexo de uma lógica de valores em nossa sociedade, agregando à natureza o valor de um bem econômico (riqueza) e de um artefato, tal como descreve Meining (1979).

O grande avanço nesse momento mais recente foi o critério de utilização, a racionalidade do uso, dentro de uma visão conservacionista que já se manifestava no país desde o início do século XX sob influência da experiência norte-americana de conservação, com a criação dos parques nacionais, que, sem dúvida, em Santo André foi "precoce" e "visionária"1 diante das poucas experiências semelhantes no país, em especial, quando patrocinada por municípios.

A importância ambiental desta área extrapola os limites territoriais do município de Santo André, como é característico de áreas naturais - uma vez que suas dinâmicas não obedecem às fronteiras político-administrativas -, e como

\footnotetext{
${ }^{1}$ Ideia extraída do depoimento concedido por Cristina M.Santiago, op.cit.
} 
vimos, há um caráter regional intrínseco entre as cidades, que impõe ao Pedroso a necessidade de uma gestão compartilhada. É uma área estratégica que além de oferecer proteção aos mananciais de abastecimento da cidade, entre outros atributos ambientais, funciona como um grande amortecimento, uma zona tampão no limite da macrozona urbana e de proteção ambiental do município de Santo André.

Várias foram as apropriações que se fizeram dessa área, como as olarias, as chácaras, o Santuário Nacional de Umbanda - utilizando o local da Pedreira Montanhão desde meados de 1950, iniciando com um grupo pequeno -, moradias, horta e viveiro municipal, concessões de uso - como a Casa de Recuperação para Dependentes Químicos (Desafio Jovem), o pesqueiro, a pista de kart - e o Parque Regional e Jardim Botânico do Pedroso, na década de 1970, em atividade desde então, passando por um período de decadência nos anos de 1990 com a transformação da região, com o encerramento de algumas atividades recreativas e com a falta de manutenção e investimentos que perdurou até aproximadamente 2005, quando retomaram-se as discussões em torno da recuperação dessa área de lazer. E a recente implantação do Rodoanel "fechou com chave de ouro"2 os usos e apropriações desse parque.

Há dois enfoques diante desse histórico de ocupação e de apropriações. Um, das políticas ambientais que desconsideram essa natureza como fruto de uma interação com o homem, na qual, portanto, há valores sociais, culturais além dos naturais a serem considerados. E o outro, sob o ponto de vista da biologia da conservação, que avalia a extensão dessas alterações e perturbações na mata influenciando na preservação ou extinção de espécies nesse fragmento.

Sob esse segundo aspecto, ficam questões a serem respondidas diante da fragmentação drástica provocada pelo Rodoanel em um parque que é equivalente ao maior Parque Municipal ${ }^{3}$ da cidade de São Paulo e que corresponde à maior reserva natural do grande $A B C$. Mas sob o ponto de vista da conservação da biodiversidade, é grande ou pequeno? Como será o comportamento das espécies diante da herança de alterações passadas e recentes? Há alguma possibilidade de conexão com os outros fragmentos mais ao sul do município e com a área urbana? Qual será o futuro das populações de espécies no Parque do Pedroso?

\footnotetext{
2 Ibid.

${ }^{3}$ Parque Anhanguera, mencionado no depoimento de Raul I. Pereira, op.cit.
} 
A categoria de manejo que o parque integra apresenta lacunas que são decorrentes de uma política ambiental que privilegia a preservação da natureza, e não o homem integrado a ela. Isso representa uma contradição conceitual que está expressa na lei ${ }^{4}$, não oferecendo instrumentos para encarar a interface com populações, especialmente a realidade urbana, tão latente no Parque do Pedroso.

A aplicação da lei pela gestão pública, entendendo a incompatibilidade da conservação na natureza diante de uma população urbana, retira o "problema" (moradores) do centro e o transfere para as bordas e para seu entorno. Embora esteja sob a vigência de uma legislação restritiva e teoricamente favorecedora dos processos naturais, não representa um impedimento para evitar um impacto violento como o Rodoanel.

Já a discussão desenvolvida no campo cultural, para áreas ambientalmente protegidas, não faz essa dissociação, entendendo essas áreas "naturais" como o "resultado do processo histórico de apropriação social da natureza". Nesse sentido, justificam-se as "micro" proteções (Pico do Bonilha, Jardim Japonês) dentro da área maior já protegida, que a priori já estariam resguardadas.

Essas apropriações, o período do "Parque Regional e Jardim Botânico do Pedroso", deixaram como herança a "vocação para o lazer", ${ }^{5}$ que foi construída nessa época passada e recente de uma maneira muito efetiva, explorando o potencial paisagístico com atividades suficientemente atraentes como foram o teleférico, o pedalinho, que catalisavam a atenção do público de toda a região.

Atualmente, com a transformação do entorno, com o crescimento dos bairros e dos assentamentos precários, passou a ser demanda de uma população numerosa e carente de opções de lazer, que pode ${ }^{6}$ e deve atuar como um importante instrumento de educação ambiental para a conservação da natureza. E, reside aí, na educação, segundo os depoimentos ${ }^{7}$ de vários dos entrevistados, a oportunidade para superação da dicotomia entre "o ambiente natural e a realidade urbana", da distância e dos preconceitos que se impõem a uma área periférica da cidade.

\footnotetext{
${ }^{4}$ SNUC.

${ }^{5}$ Ideia extraída do depoimento de Luiz H. R. Zanetta, op.cit.

${ }^{6} \mathrm{O}$ desenvolvimento de atividades de educação e interpretação ambiental, de recreação em contato com a natureza e de turismo ecológico são objetivos da categoria Parque Nacional, previstos no SNUC, capítulo III, art.11.

${ }^{7}$ Depoimentos de Raul I. Pereira (2009), Cristina M. Santiago (2009), Miguel e Maria B. Pastor (2009) e Luiz H. R. Zanetta (2010).
} 
A realização de um exercício como o biomapa (existem muitos outros instrumentos), mostrou que este pode ser uma importante ferramenta de participação, de aproximação da comunidade com os gestores, expondo a relação, os vínculos, o conhecimento e as carências daquele grupo diante do Pedroso, que pode orientar ações e direcioná-las para programas e projetos voltados para a gestão da área e para a educação ambiental.

Entre outras coisas, os participantes expuseram a deficiência da estrutura recreativa do parque - muito embora o projeto de revitalização da área de lazer tenha sido implantado apenas parcialmente - e um desconhecimento do seu caráter como unidade de conservação. "O parque não passa de uma grande churrasqueira”, foi uma das falas na oficina. É nesse sentido que a proposição de um desenho - um projeto - pode contribuir no dimensionamento das necessidades, das demandas, agindo na mediação dos conflitos existentes.

A arquitetura se coloca nessa direção, dando respostas às questões do nosso tempo. E no Pedroso, com suas características e com uma herança voltada para o lazer, há o valor social do uso, que deve ser considerado como um ganho para a natureza, e não como uma perda. ${ }^{8}$

A obra de Ruy Ohtake da década de 1970 - as três estações do teleférico ${ }^{9}$ - é um exemplo de arquitetura modernista integrada à paisagem que resiste ao tempo (apesar da falta de manutenção), cuja falta de atribuição de um novo uso (com o encerramento da atividade do teleférico e pela inviabilidade econômica de sua reativação) a torna desconectada do contexto, quase sem sentido de estar ali, se não conhecemos sua história.

Outro aspecto que é estruturante no Parque do Pedroso e consenso, pelo menos na área da arquitetura - pelos entrevistados -, é a exploração da água como potencial de uso para o lazer, com "um uso múltiplo de recreação, lazer e

\footnotetext{
8 Depoimento de Raul I. Pereira, op.cit. Essa questão foi levantada referindo-se à opção de determinados materiais no projeto: "Não penso que é necessário integrar, com uma visão de que a arquitetura é somente uma continuidade e decorrência direta do espaço natural! Nisso, o Movimento Moderno possui alguns exemplos interessantes. Mostra-se que a natureza não é incompatível com a obra de alta tecnologia, mesmo que em muitos casos, cause uma estranheza à primeira vista. Tudo depende de como trabalhamos com o programa de necessidades, com os materiais, com as formas e com o respeito à cultura do lugar. (...) Não vejo como contraditória a arquitetura modernista ou não modernista, uma arquitetura com uma linguagem mais contemporânea ou da área que se tenha pavimentação, em relação às áreas mais naturalizadas. Levar mais pessoas, confortavelmente, para conhecer o parque é um ganho para a natureza, não é uma perda!"

${ }^{9}$ Ibid. Nesse depoimento há uma descrição da marquise da estação de saída do teleférico, também chamada de estação $A$, de acordo com a nomenclatura constante no projeto original, que fala de uma integração: "Vejo a obra de Ruy Ohtake, daquele período da década de 1970, da construção do teleférico, de uma integração com a natureza, muito delicada no modo como a marquise se abre para
} 
educação ambiental", com brinquedos hídricos, expondo a água como elemento mais fundamental do parque. Um uso técnica e legalmente compatível com a captação para abastecimento público, que não comprometeria a qualidade da água - apenas contribuindo com algum acréscimo de poluição difusa, que já está incorporada atualmente e que pode ser minimizada, se estiver associada a um manejo dos corpos d'água. ${ }^{10}$

O uso recreativo da água está previsto na Legislação Federal ${ }^{11}$, permitindo para a Classe Dois a recreação de contato primário, como natação, esqui aquático e mergulho. Para águas enquadradas na Classe Três, só admite-se a recreação de utilização secundária, cujo contato com a água é esporádico ou acidental, como atividades de pesca e a navegação (como o pedalinho).

O enfoque da paisagem mostra que há uma pluralidade de compreensões, que não é possível abarcá-la em uma única perspectiva. Diante dessa complexidade, a gestão precisa ser compartilhada por vários setores da sociedade. A retomada de um grupo gestor é essencial para que a tomada de decisões seja democratizada e que as informações sejam apropriadas pela sociedade, resguardando o parque das descontinuidades de programas e projetos que são marca da prática da gestão pública.

Esse grupo está previsto no SNUC com um caráter mais amplo do que aquele que atuou em 2005 e reunia apenas representantes da gestão pública. Um conselho consultivo, presidido pelo órgão gestor, formado por representantes de organizações da sociedade civil e da gestão pública, acrescentando que, no caso do Pedroso, deveria ser extensivo aos municípios vizinhos envolvidos - Mauá e São Bernardo do Campo, abrindo espaço para o grupo que discute as questões culturais da cidade, a fim de unificar as discussões que caminham paralelamente e para a Federação Umbandista, cujo uso do parque precisa convergir para uma gestão comum, integrada com a gestão maior do parque. ${ }^{12}$

aquele lado da paisagem, com apenas dois bloquinhos: um banheiro no canto, e uma lanchonete (demolida), donde, no fundo, se descortina o lago... Com um material durável que é o concreto."

10 No depoimento realizado em 20 de julho de 2010, Luiz H. R. Zanetta fala que os lagos do Parque do Pedroso poderiam ter uma coleção de espécies palustres e aquáticas, manejo de peixes e que há dispositivos hídricos que podem fazer o controle da poluição antes da água chegar ao lago principal (e ainda contando que há o tratamento antes da distribuição pública, na ETA Guarará).

${ }^{11}$ Resolução CONAMA $n^{\circ} 357$, de 17 de março de 2005. A lei específica da Billings (Estadual), Lei $n^{\circ}$ 13.579, de 13 de julho de 2009, capítulo VII, no artigo 19, descreve que são admitidas em Áreas de Restrição à Ocupação - ARO: "atividades de recreação e lazer, educação ambiental e pesquisa científica, desde que não causem impacto ambiental significativo" (sem grifo no original).

12 A gestão do santuário, apartada da gestão maior, foi apontada no depoimento de Cristina M. Santiago, op.cit. 
O reconhecimento de novas categorias de manejo, como as RESEXs e APAs, dentro da estrutura hermética do SNUC foram conquistas que partiram da expressão da sociedade e garantiram o direito ao trabalho pela exploração da mata, o desenvolvimento dos territórios compatibilizando-o com a preservação.

O reconhecimento do patrimônio natural foi também uma conquista da sociedade, quando considera-se o componente cultural das paisagens como um patrimônio coletivo dos povos ligado às práticas sociais e à memória coletiva (Scifoni, 2006).

A superação de certas contradições entre a legislação aplicada ao parque e sua realidade histórica urbana pode ser superada em um plano de manejo que venha considerar e suprir essas deficiências, compreendendo as dimensões culturais e ambientais dessa área e se for aplicado a uma gestão aberta a participação da população envolvida com o parque, usuários, moradores, com a sociedade enfim, já que descobrimos que apenas um 'título' de unidade de conservação e as leis, não são suficientes para garantir sua proteção. 


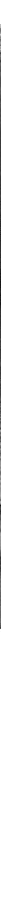




\section{Publicações}

ACKERMAN, Márcio P.; ARAÚJO, Reinaldo H. Laudo Técnico para autos $n^{\circ}$ 821/92 de Ação Cível Pública Ambiental.São Paulo, 1998.

BESSE, Jean-Marc. Ver a terra: seis ensaios sobre a paisagem e a geografia. Tradução: Vladimir Bartalini. São Paulo, Perspectiva, 2006.

BIANCHINI, Rosângela S. Impactos do Rodoanel na vegetação do ABC. Palestra proferida no Museu de Santo André Dr. Octaviano Armando Gaiarsa, Santo André, em 25 nov. 10 .

BRASIL. Monitoramento do desmatamento nos Biomas Brasileiros por satélite. Acordo de cooperação técnica MMA / IBAMA. Monitoramento do Bioma Mata Atlântica 2002 a 2008. Brasília, 2010. Disponível em http://siscom.ibama.gov.br/monitorabiomas/mataatlantica/RELATORIO PMDBBS MATA ATLANTICA 2002-2008.pdf. Acessado em 15 jan.2010.

BRASIL. Ministério do Meio Ambiente. O corredor central da mata atlântica: uma nova escala de conservação da biodiversidade / Ministério do Meio Ambiente, Conservação Internacional e Fundação SOS Mata Atlântica. - Brasília : Ministério do Meio Ambiente; Conservação Internacional, 2006.

CARVALHO, Marcos. O que é Natureza. 2 ed.São Paulo: Editora Brasiliense, 2003.

COSTA NETO, Joaquim de Britto. A Questão Fundiária nos Parques e Estações Ecológicas do Estado de São Paulo. Origens e Efeitos da Indisciplina da Documentação e do Registro Imobiliário. Tese de Doutorado, Faculdade de Arquitetura e Urbanismo da Universidade Estadual de São Paulo, 2006.

DEAN, Warren. A Ferro e Fogo. A História e a Devastação da Mata Atlântica Brasileira. São Paulo, Companhia das Letras, 2002.

DIEGUES, Antonio C.S. O Mito Moderno da Natureza Intocada. HUCITEC e Núcleo de Apoio à Pesquisa sobre Populações Humanas em Áreas Úmidas BrasileirasNUPAUB / USP. São Paulo, 2001.

EMPLASA - Empresa Paulista de Planejamento Metropolitano. Indicadores Metropolitanos: Região Metropolitana de São Paulo - Meio Ambiente. Disponível em:

http://www.emplasa.sp.gov.br/portalemplasa/produtos\%20download/IME/Meio\%20A mbiente.pdf. Acesso em 25 nov 2010.

EMPLASA-Empresa Paulista de Planejamento Metropolitano. Projeto UITs (Unidades de Informações Territorializadas): Região Metropolitana de São Paulo Região Sudeste (Grande ABC). Disponível em: http://www.emplasa.sp.gov.br/portalemplasa/uit/abc.htm. Acesso em 18 nov 2010

FENOLON, Déa Ribeiro. O papel da História Oral na Historiografia Moderna. In MEIHY, op. cit. 
FESPSP- Fundação Escola de Sociologia e Política de São Paulo. Complementação do Estudo de Impacto Ambiental das Obras do Trecho Sul Modificado do Rodoanel Mário Covas. Atendimento aos itens 1A, 1B, 1C, 1D, 1E, e 2Ado Termo de Referência do Parecer Técnico IBAMA $n^{\circ}$ 25/2005. Relatório Final. 15/jul/2005.

Fundação Escola de Sociologia e Política de São Paulo. Complementação do Estudo de Impacto Ambiental das Obras do Trecho Sul Modificado do Rodoanel Mário Covas. Atendimento aos itens $2 B$ e $2 C$ do Termo de Referência do Parecer Técnico IBAMA $n^{\circ}$ 25/2005. Estudos de Vegetação.

- Fundação Escola de Sociologia e Política de São Paulo. Complementação do Estudo de Impacto Ambiental das Obras do Trecho Sul Modificado do Rodoanel Mário Covas. Atendimento ao ítem 2D do Termo de Referência do Parecer Técnico IBAMA $n^{\circ}$ 25/2005. Estudos de Fauna.

FUNDAÇÃO SOS MATA ATLÂNTICA. Dossiê Mata Atlântica. São Paulo, 1982. In Santiago, Op. Cit.

FUGABC- Federação Umbandista do Grande ABC. Relatório de documentos para regularização no SEMASA. 2005.

GAIARSA, Octaviano Armando. A cidade que dormiu três séculos. Prefeitura Municipal de Santo André, 1991.

GONÇALVES, N.J.B. e MORENO, R.S. O quadro ambiental de Santo André para o eixo temático 1: Desenvolvimento e Sustentabilidade Socioambiental. Apresentado na $1^{\text {a }}$ Conferência Municipal de Saúde Ambiental. Santo André, set 2009.

HESS, G.R.; FISHER, R.A. Communicating clearly about conservation corridors. In: Landscape and Urban Planning, v. 55, 2001.

HOLANDA, Sérgio Buarque de. Raízes do Brasil. Rio de Janeiro. Ed. José Olympio, 1989.

IBAMA. Ecossistemas Brasileiros. Edições Ibama, Brasília, 2001a.

IBAMA, MMA. Roteiro Metodológico para Gestão de Área de Proteção Ambiental. APA. Edições Ibama, Brasília, 2001b.

IBGE - Instituto Brasileiro de Geografia e Estatística - Ministério do Planejamento, Orçamento e Gestão. Censo de 2010. Brasília, 2010. Disponível em: http://www.ibge.gov.br/home/estatistica/populacao/censo2010/tabelas pdf/total pop ulacao sao paulo.pdf. Acesso em 25 nov 2010.

KLINK, Johannes Jeroen. A cidade-região: regionalismo e reestruturação no Grande ABC Paulista. Editora DP\&A, Rio de Janeiro, 2001. 
KORMAN, Vânia. Proposta de integração das glebas do Parque Estadual de Vassununga (Santa Rita do Passa Quatro, SP), 131 f. Dissertação (Mestrado em Ecologia de Agroecossistemas) - Escola Superior de Agricultura "Luiz de Queiroz", Universidade de São Paulo. Piracicaba, 2003.

LANG, Alice Beatriz da Silva Gordo. História Oral: Muitas Dúvidas, poucas certezas e uma proposta. In MEIHY, op. cit.

LAVENDOWISK, Izabel; MOSCATELLI, Ricardo; MORAES, Elaine. Gestão de Unidades de Conservação em regiões metropolitanas - O caso do Parque Natural do Pedroso - Santo André-SP. Texto, SEMASA, 2006.

LEITE, Ricardo Augusto Soares. Reflexões Acerca do Termo de Ajustamento de Conduta. Disponível em:

http://www.escola.agu.gov.br/revista/Ano V julho 2005/RicardoAugusto Reflexoes AjustamentodeConduta.pdf. Acesso em 20 Abr. 2009.

LIMA E SILVA, Pedro P.; GUERRA, Antonio J.T.; MOUSINHO, Patrícia [Org]; autores: BUENO, Cecília [et.al.].Dicionário Brasileiro de Ciências Ambientais. Rio de Janeiro, Thex Ed., 1999.

LOUZADA, J.N.C.; SOUZA, O.F.F; BERG, E. Ecologia e manejo de fragmentos florestais. Lavras: Universidade Federal de Lavras - FAEP, 2001.

LUYMES, Don; PROFT, Joanne. Mananciais Sustentáveis. Desenho da Paisagem Urbana Para Assentamentos de Baixa Renda. Charrette do Projeto para a vizinhança Pintassilgo. UBC University of British Columbia; CHS Centre for Human Settlements, Centre for Landscape Research, James Taylor Chair in Landscape and Liveable Environments; Faculdade de Arquitetura e Urbanismo da Universidade de São Paulo. 2001. Revista

MATARAZZO-NEUBERGER, W.M. Avifauna urbana de dois municípios da Grande São Paulo (Santo André e São Bernardo do Campo). Dissertação de Mestrado. Instituto de Biociências da Universidade de São Paulo, 1986. In UMAH, op.cit.

MATARAZZO-NEUBERGER, W.M. Guildas, organização e estrutura da comunidade: análise da avifauna da represa Billings, SP. Tese de Doutorado. Instituto de Biociências da Universidade de São Paulo, 1994. In UMAH, op.cit.

MATARAZZO-NEUBERGER, W.M. Aves de uma seção de Mata Atlântica, Santo André, SP. In Simpósio de Ecossistemas da costa sul e sudeste brasileira, 2, vol.1 Águas de Lindóia, SP., 1990. In UMAH, op.cit.

MEDEIROS, Rodrigo. Evolução das tipologias e categorias de áreas protegidas no Brasil. Ambiente \& Sociedade - Vol.IX $n^{0} 1$ jan./jun. 2006 - disponível em http://www.scielo.br/pdf/asoc/v9n1/a03v9n1.pdf. Acesso em 20 nov.2010

MEDICI, Ademir, Migração, Urbanismo e Cidadania. A História de Santo André contada por seus Personagens. Prefeitura Municipal de Santo André, Projeto Viva Cidade, 1992.

MENESES, Ulpiano T. Bezerra. A paisagem como fato cultural . In Yázigi, Eduardo. Turismo e Paisagem . Coleção Turismo Contexto. São Paulo, 2002. 
MEIHY, J. C. Sebe Bom (org.) (Re) Introduzindo História Oral no Brasil. Faculdade de Filosofia, Letras e Ciências Humanas - FFLCH. Universidade Estadual de São Paulo, 1996.

MEINING, Donald W.: The beholding eye. Ten versions of the same scene. In The interpretation of ordinary landscape. Londres: Oxford University Press, 1979.

METZGER, J.P. Estrutura da paisagem e fragmentação: análise bibliográfica. In: Anais da Academia Brasileira de Ciência, Rio de Janeiro, 1999. Anais, Rio de Janeiro: v. 71, no 3-1, p. 445-463, 1999.

MINAYO, Maria Cecília de Souza. O Desafio do Conhecimento. Pesquisa Qualitativa em Saúde. Hucitec-Abrasco, São Paulo-Rio de Janeiro, 1992.

MORENO, Robson da Silva. Gestão Local Participativa em Santo André, São Paulo: Gerenciamento Participativo em Áreas de Mananciais. Dissertação de Mestrado, Faculdade de Arquitetura e Urbanismo da Universidade Estadual de São Paulo, 2004.

OLIFIERS, Natalie; CERQUEIRA, Rui. Fragmentação de Habitat: Efeitos Históricos e Ecológicos. In Rocha, op.cit.:261

OLIVEIRA, Adriana Fernandes de. Urbanização em Área de Preservação Ambiental: O Caso da Vila de Picinguaba, Município de Ubatuba. Dissertação de Mestrado, Faculdade de Arquitetura e Urbanismo da Universidade Estadual de São Paulo, 1999.

PASSARELLI, Silvia H. F. Notas sobre a Evolução Urbana da Borda do Campo. O Impacto da Ferrovia no Ambiente. Curso de Pós Graduação: "Estruturas Ambientais Urbanas". Faculdade de Arquitetura e Urbanismo da Universidade Estadual de São Paulo, 1990.

O Diálogo entre o Trem e a Cidade: O Caso de Santo André. Dissertação de Mestrado, Faculdade de Arquitetura e Urbanismo da Universidade Estadual de São Paulo, 1994.

PAGLIA, Adriano P.; FERNANDEZ, Fernando A. S.; DE MARCO JR, Paulo. Efeitos de Fragmentação de Habitats: Quantas Espécies, Quantas Populações, Quantos Indivíduos, e Serão Eles Suficientes? In Rocha, op.cit.:281

PEREIRA, Raul I. Memorial Descritivo da Revitalização do Parque Natural Municipal do Pedroso. Escritório de arquitetura Raul Pereira arquitetos associados Ltda. 2007.

PIRES, Alexandra S.; FERNANDEZ, Fernando A. S.; BARROS, Camila S. Vivendo em um Mundo em Pedaços: Efeitos da Fragmentação Florestal sobre Comunidades e Populações Animais. In Rocha, op.cit.:231

Relatório da Commissão de Melhoramentos de São Bernardo. Apresentado ao Exmo. Sr. Saladino Cardoso Franco M.D. Prefeito Municipal, 1916. Ed. Augusto Siqueira \& C.: São Paulo, 1917. FCMSB, acervo MSAOAG. 
Prefeito Saladino Cardoso Franco, 1919. Ed. TYP. Augusto Siqueira \& C.: São Paulo, 1920. FCMSB, acervo MSAOAG.

Relatório apresentado à Câmara municipal de São Bernardo. Prefeito Saladino Cardoso Franco, 1921 Ed. Duprat \& Cia, São Paulo, 1922. FCMSB, acervo MSAOAG.

- Prefeito Saladino Cardoso Franco, 1924. Ed.TYP. S. José, Santos. 1925. FCMSB, acervo MSAOAG.

Paulo. 1928. FCMSB, acervo MSAOAG

Prefeito Saladino Cardoso Franco, 1927 Ed.TYP Siqueira, São

Relatório da Commissão de Melhoramentos de São Bernardo. Apresentado ao Exmo. Sr. Saladino Cardoso Franco M.D. Prefeito Municipal. São Paulo, 1928a. FCMSB acervo MSAOAG.

Relatório da Commissão de Melhoramentos de São Bernardo por Plínio António Branco. Typographia Nilson, São Paulo, 1928b. FCMSB, acervo MSAOAG.

Religiões e Crenças em Santo André, mimeo, 2006-2007. In Processo no 10952/08, fl. no 14. Prefeitura Municipal de Santo André, 2008.

RIBEIRO, Rafael W. Paisagem Cultural e Patrimônio. IPHAN/COPEDOC. Rio de Janeiro, 2007.

RITTER, Joachim. Paisagem. Função estética na sociedade moderna. Tradução do original alemão para o francês: Gerard Raulet - Paysage, fonction de l'esthétique dans la societé moderne. Besançon, Les Éditions de l'Ímprimeur, 1997.

Tradução do francês para o português: Vladmir Bartalini, para uso exclusivo da disciplina AUP 5886 Paisagem e Arte - Intervenções Contemporâneas, 2008.

ROCHA, Carlos, et.al. Biologia da Conservação: Essências. Ed. Rima. São Carlos, 2006.

RODRIGUES, Marly. (org.) Santo André: Cidade e Imagens.Prefeitura Municipal de Santo André. Ed. Bandeirantes, São Paulo, 1991.

SANTIAGO, Cristina de Marco. Relatório circunstanciado. SEMASA, 2001.

Relatório circunstanciado. SEMASA, 2003.

SANTO ANDRÉ, Prefeitura Municipal de. Relatório do Plano Diretor - Diagnóstico. Departamento de Planejamento Urbano, 1991.

Prefeitura municipal de. Caderno de Planejamento de Bairros. COPLAN/DPU, Santo André,1992.

Prefeitura Municipal de. Fundamentação do Projeto de Lei do Plano Diretor Participativo do Município de Santo André; Secretaria de Desenvolvimento Urbano, 2004. 
Prefeitura Municipal de, SUBPREFEITURA de Paranapiacaba e

Parque Andreense. Biomapa: metodologias e experiências. Santo André, 2005.

Prefeitura Municipal de. Plano Municipal de Habitação. Santo

André, 2006.

Religiões e Crenças em Santo André, mimeo, 2006-2007. In Processo no 10952/08, fl. no 14. Prefeitura Municipal de Santo André, 2008.

Prefeitura Municipal de.; SEMASA, Serviço Municipal de Saneamento Ambiental de Santo André; Instituto Ecoar para Cidadania. Parque Natural do Pedroso: Patrimônio da Vida. Santo André, 2007a.

Prefeitura Municipal de Santo André. Sumário de dados 2008,

$2008 a$

Prefeitura Municipal de. Plano Municipal de Áreas Verdes e Arborização Urbana, 2008b.

SÃO BERNARDO DO CAMPO, Prefeitura Municipal. Sumário de Dados 2009. 2009.

SANTOS, Wanderley dos. Antecedentes Históricos do ABC Paulista: 1550 - 1892. Prefeitura do Município de São Bernardo do Campo. Secretaria de Educação, Cultura e Esportes. Departamento de Cultura, 1992.

SÃO PAULO (Estado). Secretaria de Estado dos Negócios da Agricultura. Coordenadoria da Pesquisa de Recursos Naturais; Instituto Florestal. Plano de Manejo para o Parque Estadual da Cantareira. Boletim Técnico n ${ }^{\circ} 10$. São Paulo, Jun 1974.

Secretaria do Meio Ambiente. Atlas as Unidades de Conservação Ambiental do Estado de São Paulo: 1998.

SEADE - Fundação Estadual de Análise de Dados. Secretaria de Planejamento e Desenvolvimento Regional. Anuário Estatístico do Estado de São Paulo - Meio Ambiente. São Paulo, 2003. Disponível em: http://www.seade.gov.br/produtos/anuario/index.php?anos=2003\&tip=ment\&opt=tab \&tema=null\&cap=1 Acesso em 26 out 2010.

SCIFONI, Simone. O verde do ABC: reflexões sobre a questão ambiental urbana. Dissertação de Mestrado, Faculdade de Filosofia, Letras e Ciências Humanas FFLCH. Universidade Estadual de São Paulo, 1994.

A Construção do Patrimônio Natural. Tese de Doutorado, Faculdade de Filosofia, Letras e Ciências Humanas - FFLCH. Universidade Estadual de São Paulo, 2006.

SEMASA. Serviço Municipal de Saneamento Ambiental de Santo André. Folder Centro de Referência em Saneamento Ambiental, Santo André, 2006. 
Centro de Referência em Saneamento Ambiental de Santo André. O Abastecimento de Água em Santo André. Aspectos Históricos e Quadro Atual. Santo André, 2008a.

SOS Mata Atlântica, Fundação e BRASIL, Ministério da Ciência e Tecnologia, Instituto Nacional de Pesquisas Espaciais - INPE. Atlas dos Remanescentes Florestais de Mata Atlântica - período 2008 - 2010. Disponível em: http://mapas.sosma.org.br/site media/download/atlas-relatorio2008-2010parcial.pdf. Acesso em 17 nov2010.

SOS Mata Atlântica. Disponível em http://www.sosmatatlantica.org.br/index.php?section=info\&action=fauna. Acesso em 15 jan 2010.

SKORUPA, Landislau A. Áreas de Preservação Permanente e Desenvolvimento Sustentável. Empresa Brasileira de Pesquisa Agropecuária - Embrapa, Ministério da Agricultura, Pecuária e Abastecimento. Jaguariúna, dezembro de 2003. Disponível em http://www.agencia.cnptia.embrapa.br/Repositorio/Skorupa areasIDGFiPs3p4lp.pdf Acesso em 26 fev. 2010

TABARELLI, M.; BAIDER, C.; MANTOVANI, W. Efeitos da fragmentação na floresta atlântica da bacia de São Paulo. Hoehnea, v. 25, n 2, p. 169 - 186. São Paulo, 1998.

UMAH. Diagnóstico de qualidade ambiental e estudo de viabilidade econômica da área de proteção de mananciais de Santo André - São Paulo. Vol. I, 2000.

WHATELY, Marussia et al. Contribuições para a elaboração de leis específicas de mananciais : o exemplo da Billings -- São Paulo : Instituto Socioambiental, 2008. disponível em http://www.mananciais.org.br/upload /billings-2008.pdf. Acesso em 20 abr. 2009.

WU \& HOBBS (2002), In PENTEADO, H.M. \& ALVAREZ, C.E. Corredores Verdes Urbanos: Estudo da Viabilidade de Conexão das Áreas Verdes de Vitória. In: Paisagem e Ambiente: Ensaios. Universidade de São Paulo, Faculdade de Arquitetura e Urbanismo. n. ${ }^{\circ} 24,2007$.

ZANZINI, A.C. da S. Princípios de ecologia e manejo da paisagem para a conservação da fauna silvestre. Universidade Federal de Lavras - FAEP. Lavras, 2001. 


\section{Periódicos}

DIÁRIO DO GRANDE ABC. Parque do Pedroso, uma opção de lazer. 18 out 1985. . Parque do Pedroso sucumbe em ruínas. 03 jun 1993. .Opinião. Conrado Bruno Corazza. Parque do Pedroso. 01 out 1999.

andreense, 27 jul 2001. - Acordo com cidade japonesa revitaliza praça . Parque do Pedroso será revitalizado. 28 jul 2005. Parque foi pólo de lazer nos anos 80. 13 out 2008.

GOLUB, Philip S. Saturação das Metrópoles. Le Monde Diplomatique Brasil - O Futuro das Cidades, ano 3, número 32, 2010. Revista 


\section{Legislação citada}

BRASIL. Constituição da república dos Estados Unidos do Brasil de 16 de julho de 1934.

BRASIL. Constituição do Brasil, promulgada em 5 de outubro de 1988. Constituição da República Federativa do Brasil. Diário Oficial da União, 1988.

BRASIL. Decreto-lei $n^{\circ}$ 25, de 23 de janeiro de 1934. Aprova o código florestal que com este baixa, 1934.

BRASIL. Decreto oㅜ 23.793 de 23 de janeiro de 1934. Decreta o código de Águas. Institui o Código Florestal.

BRASIL. Decreto № 23.672 de 01 de fevereiro de 1934. Aprova o código de Caça e Pesca.

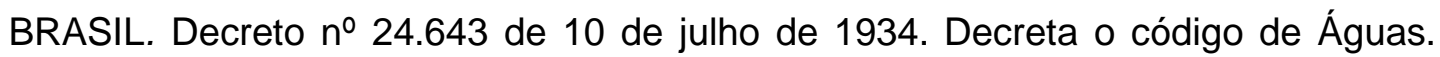
1934.

BRASIL. Decreto № 24.645 de 10 de julho de 1934. Código de Proteção aos Animais.

BRASIL. Decreto-lei no 25, de 30 de novembro de 1937. Organiza a proteção do patrimônio histórico e artístico nacional. 1937.

BRASIL. Decreto-lei no 25, de 30 de novembro de 1937. Organiza a proteção do patrimônio histórico e artístico nacional. 1937.

BRASIL. Lei no 4.771, de 15 de setembro e 1965. Institui o novo Código Florestal. Diário Oficial da União, 1965.

BRASIL. Lei $n^{\circ} 5.197$, de 3 de janeiro de 1967. Dispõe sobre a proteção à fauna e dá outras providências. Diário Oficial da União, 1967.

BRASIL. Decreto no 289, de 28 de fevereiro de 1967. Cria o Instituto Brasileiro de Desenvolvimento Florestal-IBDF

BRASIL. Lei complementar no 14 de 8 de junho de 1973. Estabelece as regiões metropolitanas de São Paulo, Belo Horizonte, Porto Alegre, Recife, Salvador, Curitiba, Belém e Fortaleza. Diário Oficial da União, 1973.

BRASIL. Decreto no 73.030, de 30 de outubro de 1973. Cria a Secretaria Especial do Meio Ambiente - SEMA

BRASIL. Lei no 9985 de 18 de julho de 2000. Regulamenta o art. 225, 1ㅜ, incisos I, II, III e VII da Constituição Federal, institui o Sistema Nacional de Unidades de Conservação (SNUC) e dá outras providências. Diário Oficial da União, 2000.

BRASIL. Lei ํo 11.428, de 22 de dezembro de 2006. Dispõe sobre a utilização e proteção da vegetação nativa do Bioma Mata Atlântica e dá outras providências. Diário Oficial da União, 2006.

BRASIL. Lei no 7.347, de 24 de julho de 1985. Disciplina a ação civil pública de responsabilidade por danos causados ao meio-ambiente, ao consumidor, a bens e 
direitos de valor artístico, estético, histórico, turístico e paisagístico e dá outras providências. Diário Oficial da União, 1985.

BRASIL. Resolução do Conselho Nacional de Meio Ambiente (CONAMA) no 09/1996 - "Estabelece corredor de vegetação área de trânsito a fauna" - Data da legislação: 24/10/1996 - Publicação DOU nº 217, de 07/11/1996, págs. 2306923070. Disponível

em: http://www.mma.gov.br/port/conama/legiabre.cfm?codlegi=208 . Acessado em 18 de agosto de 2010.

BRASIL. Resolução do Conselho Nacional de Meio Ambiente (CONAMA) no 302/2002 - "Dispõe sobre os parâmetros, definições e limites de Áreas de Preservação Permanente de reservatórios artificiais e o regime de uso do entorno" Data da legislação: 20/03/2002 - Publicação DOU no 090, de 13/05/2002, págs. 6768. Disponível em: http://www.mma.gov.br/port/conama/legiabre.cfm?codlegi=298. Acessado em 18 de agosto de 2010.

BRASIL. Resolução do Conselho Nacional de Meio Ambiente (CONAMA) no 392/2007 - "Define vegetação primária e secundária de regeneração de Mata Atlântica no Estado de Minas Gerais" - Data da legislação: 25/06/2007 - Publicação DOU no 121, de 26/06/2007, pág. 41-42. Disponível em: http://www.mma.gov.br/port/conama/legiabre.cfm?codlegi=299 . Acessado em 15 de setembro de 2010.

BRASIL. Resolução do Conselho Nacional de Meio Ambiente (CONAMA) no 357/2005 - Dispõe sobre a classificação dos corpos de água e diretrizes ambientais para o seu enquadramento.

BRASIL. Decreto $n^{\circ} 73.030$ de 30 de outubro de 1973. Cria a Secretaria Especial do Meio Ambiente - SEMA

BRASIL. Portaria IBAMA № 37-N, de 3 de abril de 1992. Reconhece como Lista Oficial de Espécies da Flora Brasileira Ameaçadas de Extinção a relação que se apresenta.Disponível em:

http://www.cetesb.sp.gov.br/licenciamentoo/legislacao/federal/portarias/

1992_Port_IBAMA_37.pdf. Acesso realizado em 18 jan 2011.

SÃO PAULO (Estado). Lei no 898, de 1 de novembro de 1975. Uso de solo para a proteção dos mananciais, cursos e reservatórios de água e demais recursos hídricos de interesse da Região Metropolitana da Grande São Paulo. Diário Oficial do Estado, 1975.

SÃO PAULO (Estado). Lei no 1172, de 17 de novembro de 1976. Delimita as áreas de proteção relativas aos mananciais, cursos e reservatórios de água, a que se refere o artigo $2^{\circ}$ da Lei $n^{\circ} 898$, de 18 de dezembro de 1975, estabelece normas de restrição de uso do solo em tais áreas e dá providências correlatas. Diário Oficial do Estado, 1976.

SÃO PAULO (Estado). Lei n 9.866, de 28 de novembro de 1997. Dispõe sob re diretrizes e normas para a proteção e recuperação das bacias hidrográficas dos mananciais de interesse regional do Estado de São Paulo. Diário Oficial do Estado, 1997. 
SÃO PAULO (Estado). Decreto $\mathrm{n}^{\circ} 25.341$ de 4 de junho de 1986. Aprova o Regulamento de Parques Estaduais Paulistas.

SÃO PAULO (Estado). Lei no 12.233 , de 16 de janeiro de 2006. Define a Área de Proteção e Recuperação dos Mananciais da Bacia Hidrográfica do Reservatório Guarapiranga - APRM-G, e dá outras providências correlatas. Diário Oficial do Estado, 2006.

SÃO PAULO (Estado). Lei 13.579, de 13 de julho de 2009. Define a Área de Proteção e Recuperação dos Mananciais da Bacia Hidrográfica do Reservatório Billings - APRM-B, e dá outras providências correlatas. Diário Oficial do Estado, 2009.

SANTO ANDRÉ. Lei no 1.862 de 21 de agosto de 1962. Imposto Territorial Rural.

SANTO ANDRÉ. Lei no 7.333, de 26 de dezembro de 1995. Plano Diretor.

SANTO ANDRÉ. Lei oㅡ 5.579 de 9 de maio de 1979. Dispõe sobre o Serviço de Limpeza Pública.

SANTO ANDRÉ. Lei n 8.696, 17 de Dezembro de 2004. Plano Diretor Participativo.

SANTO ANDRÉ. Lei $n^{\circ} 7.091$ de 05 de setembro de 2008, instituiu o PPPC - Plano de Preservação do Patrimônio Cultural no Município de Santo André.

SANTO ANDRÉ. Lei o 7.733 de 14 de outubro de 1998, dispõe sobre política municipal de gestão e saneamento ambiental e dá outras providências.

SANTO ANDRÉ. Lei $n^{\circ} 8.696$ de 17 de Dezembro de 2004. Institui o novo Plano Diretor do município de Santo André, nos termos do artigo 182 da Constituição Federal, do capítulo III da Lei no 10.257, de 10 de julho de 2001 - Estatuto da Cidade - e do Título V, Capítulo III, da Lei Orgânica do Município de Santo André.

SANTO ANDRÉ. Decreto Municipal $n^{\circ} 73$ de 18 de novembro de 1944, para desapropriação de terras na região do Parque do Pedroso para obras de passagem da adutora de captação das águas para abastecimento público.

SANTO ANDRÉ. Lei Municipal $n^{0} 4.167$ de 08 de novembro de1973. Dispõe crédito para desapropriações, projeto e execução do Parque Florestal do Reservatório o Pedroso.

SANTO ANDRÉ. Decreto Municipal no 922 de 19 de fevereiro de 1955, declara terras de utilidade pública para proteção sanitária da Águas do Ribeirão Pedroso e contribuinte, e constituição de reserva florestal.

SANTO ANDRÉ. Lei Municipal $n^{\circ} 3.300$ de 13 de novembro de 1969, cria o Serviço Municipal de Água e Saneamento de Santo André, SEMASA, extinguindo o Departamento de Água e Esgotos.

SANTO ANDRÉ. Decreto $n^{0} 9.709$ de março de 1979. Fica denominado 'Parque Regional e Jardim Botânico do Pedroso', o imóvel situado na Zona Rural (...) 
SANTO ANDRÉ. Lei no 5.603, de 12 de julho de 1979 o Horto Municipal do Pedroso passou a denominar-se Parque Regional e Jardim Botânico do Pedroso.

SANTO ANDRÉ. Lei Municipal $n^{\circ} 8.881$ de 4 de outubro de 2006. Altera a denominação do Parque Regional e Jardim Botânico do Pedroso para "Parque Natural do Pedroso".

SANTO ANDRÉ. Lei 5.823 de 08 de maio de 1981. Art. 1ํ - Fica a Prefeitura Municipal de Santo André autorizada a aprovar os loteamentos denominados Jardim Riviera e Parque Miami, sem prejuízo das ações judiciais ou extra-judiciais cabíveis, visando compelir os loteadores a cumprir suas obrigações legais. Disponível em http://www.cmsandre.sp.gov.br/legislacao/fr legis.htm. Acesso realizado em 16 jan 2011.

SÃO BERNARDO. Lei de parcelamento do solo nº. 271 de 1929. 


\section{Fontes Documentais Citadas}

SEMASA. Manifestação Referente ao Relatório Preliminar (RAP) CTEEP, 2008b. Org.: Biólogo Reinaldo Kruegel de Melo.

Parecer Técnico do Licenciamento Ambiental do Empreendimento Rodoviário - RODOANEL Mário Covas - Trecho Sul. SEMASA, 2007.

Processo $\mathrm{n}^{\circ} 20.584$ de 26 de junho de 1981. Aprovação dos Loteamentos Parque Miami e Jardim Riviera. Prefeitura Municipal de Santo André.1981

Processo $n^{\circ} 42725$ 98/8. Tombamento do Maciço do Bonilha, COMDEPHAAPASA, Prefeitura Municipal de Santo André, 1998.

Processo n 10/2007. Departamento de Projetos e Obras-DPO-SEMASA, 2007.

Processo $n^{\circ}$ 10952/2008. Tombamento do Jardim Japonês "Cidade Takazaki", COMDEPHAAPASA, Prefeitura Municipal de Santo André, 2008. 


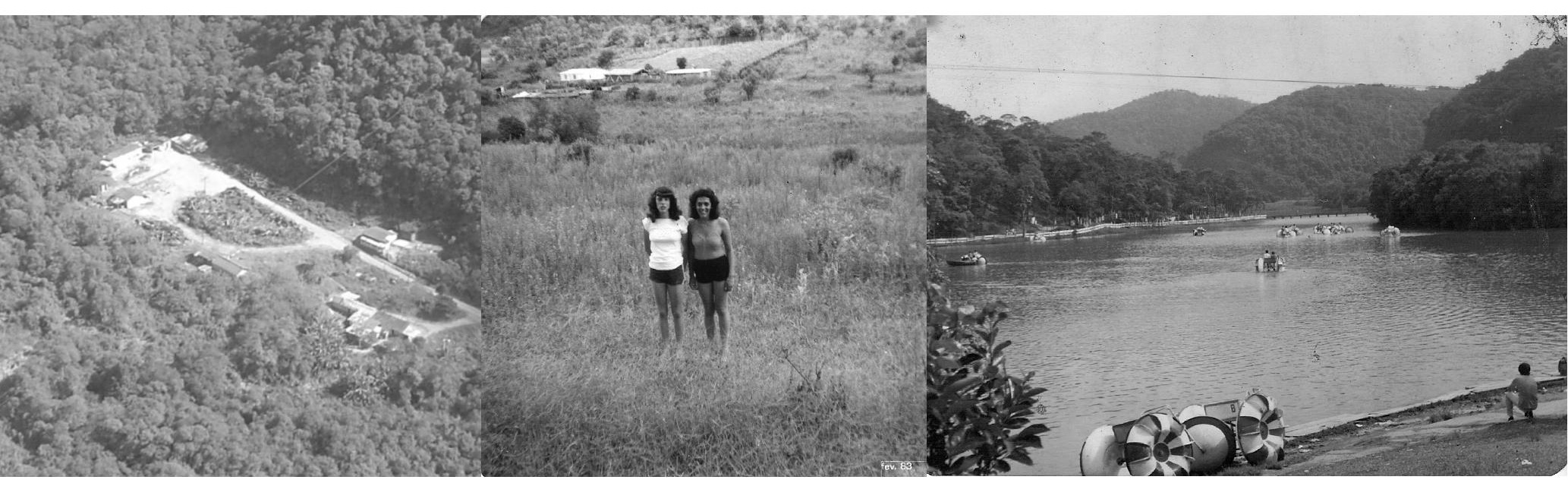

Anexo I

Entrevistas 
Miguel Pastor e Maria Basso Pastor 
Entrevistados: Miguel Pastor e Maria Basso Pastor

Local: Centro de Referência em Saneamento Ambiental-SEMASA, Santo André-SP

Data: 13 de Maio de 2009

Duração: 1 h 28 min

\section{Como é que começou a história de vocês com o Parque do Pedroso?}

(D. Maria) Foi mais ou menos em 1970, quando nós morávamos em outro local e meu marido já trabalhava no parque. Nessa época, ele ainda era motorista quando me disse: "Maria, nós não vamos mais pagar aluguel porque a prefeitura nos cedeu uma casa para morar".

Eu não perguntei aonde era, nem como era. Eu só não queria mais pagar aluguel. E quando chegamos lá no final da Vila Luzita, eu olhei e falei:

"Gente, como que eu vou morar aqui?"

Então meu marido (Sr. Miguel) falou assim:

"Não, amor. Aqui não, aqui está clarinho. Nós vamos morar ali onde está aquela luzinha."

Era muito escuro e só existia aquela luz mesmo, não tinha outra coisa. Ficava na curva dos Tanques dos Turcos, bem onde hoje estão os teleféricos. Era como o chamavam antigamente. O Tiro de Guerra era lá. Então, quando clareou o dia, Miguel falou:

"Vem olhar". E realmente era um paraíso... E eu passei todos aqueles anos ali, até mais ou menos quando começaram a cortar os morros para a construção dos teleféricos.

Miguel sempre foi um excelente funcionário. Sempre se destacou por isso, pela dedicação, sem nunca marcar o cartão atrasado, por exemplo. Todo departamento queria que o Sr. Miguel trabalhasse lá. Então, naquela época, o setor que ele trabalhava era o Parques e Jardins. Hoje chama-se DPAV ${ }^{1}$.

\section{Quando o Sr. Miguel começou a trabalhar no DPAV?}

Em 1968. O encarregado na época era o "Bigode" - Sr. Antônio Moreira. Então, o Sr. Antônio Moreira já morava na área dentro do viveiro² ${ }^{2}$ que tinha duas casas.

\footnotetext{
${ }^{1}$ Departamento de Parques e Áreas Verdes da Prefeitura Municipal de Santo André.

${ }^{2}$ Viveiro de mudas ornamentais da Prefeitura Municipal de Santo André.
} 


\section{Aonde é o viveiro atualmente?}

Hoje tem as duas casas lá. Uma era a escolinha Arco-íris, dentro do viveiro, e na outra casa morava o "Bigode". Faz muito tempo que não vou lá.

Eu morei mais ou menos uns seis, sete anos. Hoje, se alguém for lá, tem o chão dela. É bem na esquina do teleférico. Há outra esquina que tinham duas casas, com um telhado só e dois portões. Próximo ao poste era minha casa. Ali moramos nós e o Sr. Luís Moraes. Começamos a morar ali e, graças a Deus, tivemos muita paz. O endereço era Estrada do Montanhão, número 1 (um). Minha casa era a número 1 (um), a do Sr. Luís era a de número 2 (dois). Era uma casa enorme e maravilhosa. Realmente maravilhosa e espaçosa.

Meu marido, nessa época, levava a comida do pessoal, porque não tinha restaurante próximo. Levava e trazia funcionários o dia todo. Isso quando abriram o parque. Foi o Corazza $^{3}$ que o desenhou. Lá dentro tinha apenas uma casinha pequenininha, não tinha cantina, onde eles tomavam um cafezinho, faziam um lanchinho, fritavam lingüiça... era o passeio do Parque do Pedroso. E foi assim que ele nasceu. Era um cartão postal...

Nesse momento, meu marido passou a trabalhar dentro do parque como coordenador, porque vieram muitos funcionários. Acho que 32, naquela época.

\section{Em que época?}

Por volta de 1974. Nunca tivemos problema algum em frente do que atualmente é a Pintassilgo ${ }^{4}$, e onde tem o posto da guarda ${ }^{5}$. Ali tinha uma trilha que levava para uma Olaria. Eu não tenho fotos, mas para você ter uma idéia, a boca da comporta da represa era ali. Havia tanto peixe do lado de lá que o meu filho pegava um saco de cebola, colocava num arco e, na boca do tubo, as tilapias iam entrando. Ele pegava as grandes, e as pequenas, soltava. Era muito limpinho, porque não morava ninguém ali.

Apenas uma mulher morava na Olaria (hoje ela já é falecida), mas ainda tem a família dela. Ela estendia as Tilapias no varal pra secar. Como eu não tinha máquina fotográfica, não fotografei nada disso. Era a única família que morava ali, depois é que veio uma família do Sr. Alfredo, o motorista. Ele faleceu esse ano ou no ano passado. A família dele foi a primeira que se mudou para lá com

\footnotetext{
${ }^{3}$ Conrado Bruno Corazza foi Superintendente do SEMASA e várias vezes Secretário de Obras da Prefeitura Municipal de Santo André.

${ }^{4}$ Pintassilgo: assentamento informal ou favela.

${ }^{5}$ Guarda Municipal, também chamada de Grupamento Ecológico.
} 
autorização, porque antes disso, ninguém morava na Pintassilgo, que também não tinha esse nome.

Além dele, a família do Sr. Zé e da Srạ. Lucia, aposentada do viveiro. Eram quatro famílias no máximo com autorização. Não tinha nada irregular. Agora é uma cidade.

Minhas crianças iam brincar lá na boca do tubo, pescavam, e, por Deus, meu marido nunca permitiu que eles tirassem nem uma folhinha das árvores. Falávamos que a árvore era a mãe e os galhinhos eram os filhinhos, então se tirassem uma folha, estariam "judiando do filhinho e ela choraria". Eles ajudavam. Quando viam alguém pescando vinham correndo chamar a gente.

\section{A senhora lembra a data da construção do teleférico?}

Eu acho que foi em 1978 que eles começaram a construir os teleféricos. Eu acho que foi mais ou menos em 1977 ou 1978. O ponto de ônibus não era onde é hoje. Ele ficava na encosta da represa. A estrada era aquilo, na beiradinha do rio, e eu tinha medo.

\section{A Estrada do Pedroso não era asfaltada?}

Não, não era. Só até onde é o mercado de hoje. Depois de lá para cá era lama, lama... E onde está o teleférico, bem na esquina, onde tem uma placa de inauguração, tinha uma árvore tão linda quanto aquela que tem no Parque do Pedroso. Como ali tinha muito barro, os carros vinham e atolavam.

Era uma paineira maravilhosa que tinha um tronco imenso, mas foi tirada na época da construção do teleférico. Os engenheiros vinham pegar água na minha casa, que era bem em frente. Eu servia uma água gelada, porque lá em casa tinha um poço com bomba que jogava a água para a caixa.

Quando construíram o teleférico, o Parque do Pedroso tinha um administrador e meu marido passou a ser coordenador. Esse administrador era o "Chicão", que disse que precisaríamos mudar dali e eu chorava... Era o Sr. Francisco, chamavam-no de Chicão. Hoje é falecido. Várias vezes ele levava meu marido para casa, por que tinha hora para entrar, mas não para sair, e meu marido nunca disse não. E ele (Chicão) falava assim:

"Vocês vão ficar muito pouco tempo aqui". Eu começava a chorar porque pensava: "para onde ir, o que eu vou fazer?". Na prefeitura eles não sabiam para onde a 
gente iria. Talvez fôssemos para a Olaria, que já estava com quatro ou cinco famílias.

\section{Em que época?}

$\mathrm{Na}$ época da construção do teleférico, porque não queriam ninguém na área, inclusive o Sr. Luís Moraes, que hoje mora na Rua 1 (um) do Parque Miami.

Levaram-nos para onde era o Desafio Jovem ${ }^{6}$, na Estrada do Montanhão. Lá no pinheirinho havia uma casa à esquerda, uma para a direita e a nossa ficava bem na esquina, onde há alguns pés de jabuticaba. Morei lá mais ou menos no ano de 1979, porque não queriam inaugurar o teleférico com alguém morando por ali. No lugar da casa seria um estacionamento.

Moraram duas famílias no Desafio, a nossa e a do Humberto (antigo coordenador, que hoje mora no Clube de Campo). Lá havia um moinho com tantas pulgas que eu tinha receio de entrar. Havia um moinho lindo, maravilhoso, com muito ferro, que as pessoas venderiam se não olhássemos. E nós não pegávamos nem pedra.

A prefeitura também colocou uma bomba d'água, arrumou a casa, pintou, fez um banheiro, separou a minha casa, que tinha o chão lindo... Achava lindo! Tinha também um caramanchão bem grande.

Meu marido voltava do trabalho com o jipe quando o administrador permitia. Porque às vezes, às dez horas da noite, ele ia a pé dali de onde nós morávamos até a esquina do teleférico.

\section{Quantos quilômetros?}

Uns três.

Da portaria do viveiro em diante era lama e mata. Depois que cortaram os morros, dali até o teleférico foi asfaltado. Então, da portaria ao viveiro era só tábua, onde ficava a saída para a represa.

Meus filhos andavam aquele trecho para tomar um ônibus para ir à escola, no Clotilde Zanei. Lá eles se formaram. Depois, minha filha foi estudar no Galeão.

Moramos lá no Montanhão até 1981, pouco tempo, mas muito complicado, pois o ônibus passava só de hora em hora. Então nem tínhamos como comprar

\footnotetext{
${ }^{6}$ Desafio Jovem foi uma concessão da Prefeitura Municipal para uma entidade sem fins lucrativos para funcionamento de uma casa para recuperação de jovens com dependência química.
} 
pão, por exemplo, por que como íamos tomar ônibus para São Bernardo, se era de hora em hora? Tinha também um santuário de umbanda.

Fui lá umas duas vezes com minha família e era lindo, maravilhoso e naquele caminho que a gente fazia a cada três passos tinha "um trabalho" até o Parque do Pedroso. Eram as bandejinhas com todo tipo de comida e bebida e algumas famílias se alimentavam daqueles alimentos. Eu falava:

"Meu Deus!"

Antes da "construção" do santuário, tinham trabalhos de umbanda até na entrada do parque. Eu tinha receio de passar perto, mas respeitava. Inclusive temos fotos do meu filho lá no campo jogando bola. Tinha um tanque com camarão, só que o que a gente pegava era pequenininho, bem novo.

Aquela senhora e os filhos dela, a família do Edmundinho, ainda estão na área. Moram mais adiante e o Donizete, que tinha a casa da direita, foi funcionário da prefeitura por bastante tempo. A mãe dele ainda vive. Quando mudamos para lá, todos eram pequenininhos, e hoje não. Eles têm filhos. Chamavam o lugar de Chácara "Suti" [sic]. Eu não conheci como Desafio Jovem, eu conheci como Chácara "Suti" [sic].

A casa era da sede. Uma casa muito boa e tinham mais ou menos dezesseis pés de jabuticaba, e se não foram arrancados, ainda deve ter. A prefeitura arrumou tudo, colocou água encanada para nós, dividiu as casas, pintou.

Só que tinha uma coisa: de repente estava na cozinha fazendo almoço quando eu olhava para a sala, tinha um morceguinho olhando para mim, ou então, de repente eu abria a porta, via uma cobra, ou lagarto, ou perereca, e eu morria de medo de sapos.

Lá tem um lago nos fundos. Tenho fotos da minha mãe pegando jabuticaba. Tinha também chuchu, mandioca e peixe, porque os peixes lá em casa quem pescava era eu, e não eles. Nos fundos dessa casa meu marido fez uma horta ao lado do lago e com uma bomba d'água nós regávamos. A bomba ficava dentro daquele braço da represa e o dia que eu resolvia pescar, chegava de manhã pescando "lambarizinha" [sic], lambari. E eu pescava também traíra, e meu filho dizia assim:

"Hoje o peixeiro passou na porta."

Mudei de lá chorando, também porque quando mudei foi porque meus filhos já tinham se formado em 1981, e como minha filha iria estudar em Santo André? Mudou toda a administração e quem sobrou no parque? Meu marido, o 
'Gordo'... Sobraram três. Nós fomos para outra casa, que até tenho uma foto onde aparece a casa e um cachorro. Morei dentro do parque, atrás da igreja.

A igreja Santa Cruz, que era do Guateli [sic] Guazzelli, subindo, passando pelos coqueiros. Na gruta era onde pegavam água. Ali tinha um portão grande, que levava para minha casa. Lá em cima pode-se ver:

"Mas aqui faltam árvores!"

Era onde estava a casa.

Aquela casa foi feita para esse administrador morar, o Chicão. Tinha fogão a lenha e água encanada. Quando se entra no parque vê-se uma casinha. Digo que o maior controle do parque estava ali, pois havia só uma entrada e uma saída, não havia como algo fugir da vista.

Lá tinha a caixa d'água com um ou dois motores que jogavam água para mim. Tinha um motor perto da casa e um outro, lá em cima onde ficavam os bichos que pertenciam ao parque e precisavam ser tratados, por exemplo: onça-pintada, jaguatirica, gavião, arara-azul, macaco etc. As "jaulas" ficavam em frente ao parquinho. Tinha um macaco que vivia 'livre' em uma delas, sabe onde eu estou hoje ${ }^{7}$ Bem em frente, naquela esquina. Ali era a jaula, naquela árvore que eu digo que era a árvore mãe do parque, eu acho maravilhosa! Foi o meu marido que plantou todas aquelas árvores lá embaixo. Plantou com a equipe dele.

Tinha um viveiro ali. Era uma 'tela passada', porque tinham vários animais: galinha d'Angola, passarinhos, canarinhos, dentro daquele viveiro tinha de tudo. Quando resolveram soltá-los, levei minha máquina fotográfica, mas não consegui fotografar. Era muito velha e não funcionou.

(Sr. Miguel) Quando fui soltar as criações, soltei os macacos, macaquinhos, saguis. Por isso que eles ainda estão por ali. Tinha também um casal de jacu.

(D. Maria) Eles voltam lá agora, os jacus voltam naquela árvore grande. Ela dá uns frutinhos vermelhinhos. Os pássaros vão pra lá comer. E os tucanos... um mais lindo que o outro. Os macaquinhos estão tão acostumados a comer banana. Nessa semana eles foram lá e "fizeram a festa".

\footnotetext{
${ }^{7}$ D. Maria mantém uma banca onde vende doces, salgadinhos e bolo de milho ao lado do parquinho infantil (central).
} 


\section{A partir de que época os viveiros de animais foram instalados? Já em 1970 quando vocês se mudaram para lá?}

Não, quando o teleférico foi construído no Parque do Pedroso que fizeram esses viveiros. Cercaram e foram trazendo os animais, e 'tinha de tudo', até galinha d'angola, pato, paturi. Havia bandos de paturis dentro da represa e na sua volta tinha um murinho onde colocaram caixotes e os patos e os paturis se reproduziam ali. Ninguém pegava os ovos. Era a coisa mais linda! Tinha peru. Todos passeando dentro do Parque! Um dos macacos maiores chamava-se Janjão, sabe? Esse era terrível. Naquele lugar, onde eu trabalho hoje (onde tem uma árvore), era a jaula da jaguatirica. Tinha um veterinário que tratava dos bichos que ficavam doentes, em umas repartições, direitinho com bebedouro, tudo bem arrumado, nos fundos da minha casa.

Seu João ia todos os dias tratar dos bichos que estavam lá em cima. O javali que era enorme, o porco-espinho e o cateto. Muitos se reproduziam lá.

Um dia, em casa, estava muito calor e eu escutei como se fosse um pulo. As portas estavam fechadas e quando eu abri a porta do meu quarto, na minha cama tinha uma pantera-negra. Era um "gato enorme"... lindo! A minha filha amava gatos, aí pensei em levá-la para ver. Quando eu levantei a mão, a pantera mostrou os dentinhos, mas não atacou. Urinou na minha cama e em cima do meu guardaroupas. Meu marido e meu filho não conseguiram laçar e ela acabou saindo pela janela para o meio da mata.

No caminho do teleférico pela Estrada do Montanhão, pela Chácara "Suti" [sic] tinha um veado. Ele tinha mais ou menos um mesmo horário para atravessar a estrada para tomar água. Nós o víamos todos os dias. A gente fazia questão de passar por lá, ao meio-dia, porque ele estaria atravessando de um lado para o outro, e uma vez, veio vindo com o filhotinho. Foi a coisa mais bonita que já vimos!

Eu dava mamadeira para os bichinhos muitas vezes. Tirava leite da cabrita que eu não sabia nem tratar direito. Em um período que eu cuidei da cabrita ela deu cria, e meu filho sarou da bronquite com o leite que eu tirava dela. Dava até mamadeira para os tatuzinhos, mas eles não sobreviveram, de jeito nenhum. Eu não sabia tratar direito, e nem tinha condições para isso ali. $E$ assim, tornavam-se comida para onça. Havia uma onça muito bonita, que um dia, quando tinha por volta de umas cinco mil pessoas no parque, lá pelas duas horas da tarde, escapou, e bem em frente à bica d'água tinha um elevadinho com duas madeiras, onde era a casa do Tarzan. As crianças brincavam e foi para lá que ela foi. Tinha uma abertura 
perto da casa do Tarzan e por sorte que foi pra lá. No parque as pessoas ficaram agarradas nas árvores, em cima das mesas...

(Sr. Miguel) Quando a onça escapou eu era o encarregado. O treinador foi colocar ração e deixou a portinha aberta, e nisso ela saiu. O Pedroso estava superlotado de gente, e eu não sei o que me deu, mas eu fiquei em frente à ponte sozinho tangendo-a, porque ela entrou para lá novamente. Como? Não sei explicar.

(D. Maria) No parque tinha uma caminhonete que ficava lá embaixo, também um caminhão e, aos domingos, os bombeiros. Primeiros-socorros em uma enfermaria, tinha tudo; um motorista disponível, caso acontecesse alguma coisa, porque tinha muita gente. As casinhas eram feitas de sapê, os quiosques eram de sapê.

Miguel, às vezes, pegava a caminhonete para fazer ronda. Quando tinha fogo no Montanhão ele acordava cedo, e só conseguia apagar lá pela meia-noite e meia. Uma vez um guarda morreu por causa do fogo, não foi? Caiu do barranco.

Aquela região é muito rica em frutas e, como eu falei, Miguel sabe onde está tudo. Ele andava no meio da mata.

Ficou linda a construção da ponte! Eu tenho uma foto dela, antiga, a escada que foi recuperada, foi o Miguel quem fez no passado. Era ele que consertava os quiosques e o parquinho. Ele era o encanador também. Hoje, se precisa trocar uma lâmpada, chamam um eletricista.

Até o parque passar por essa bela reforma, quem fazia isso tudo era ele. Porque, às vezes, quando quebrava a descarga, o balanço, ele que arrumava. No tempo que ficamos lá era assim.

O parque foi abandonado? Não, não foi abandonado, eu não considero o parque assim. Da época do fechamento do teleférico para cá que ficou desse jeito. O parque foi perdendo as coisas boas que ele possuía.

$\mathrm{Na}$ frente do Jardim Japonês, à esquerda, tinham dois lagos, e aquela área era toda cercada, só que foi quebrando, foram deixando, e então é assim: se você não conservar sua casa, ela vai quebrando. Fica difícil depois, e o povo destrói mesmo.

Eu estou lá e, às vezes, eu brigo, porque não posso ver isso, não aguento ver, por exemplo, uma pessoa estragando uma árvore, quebrando uma mesa ou 
arrancando aquelas grelhas que estavam todas chumbadas. Foi Miguel quem chumbou porque estavam levando todas as grelhas e não ia sobrar nada. Então procuramos ajudar. Para nós mesmos, para nossos filhos, nossos netos.

Havia um almoxarifado. No paredão perto do prédio da antiga cantina e da administração, não tem aquele meio? Aquele paredão era o almoxarifado. Era dali que saíam todas as ferramentas, tudo o que saía para os trabalhadores era do almoxarifado, a gente fazia festa junina ali.

Lá também tinha uma horta. O pessoal só levava semente para ele, ninguém pagava nada, ele não deixava ninguém pagar, porque ele dava. Era uma horta maravilhosa. Quando ele sofreu um acidente e voltou não tinha mais nada...

O parque era maravilhoso todo florido, sempre tivemos muito carinho... sabe o que daria na casa onde morei? Um restaurante maravilhoso.

\section{O pedalinho funcionou na mesma época do teleférico?}

O teleférico, o pedalinho, a estação de embarque e os bombeiros.

A estação de embarque que foi demolida. Tinha uma estação de embarque de onde saíam os pedalinhos. Colocavam as bóias, que eu não sei como chamavam, daí os pedalinhos saíam; davam a volta até na barragem da entrada do viveiro em meia hora.

Então, eu mesma atendi pessoas do Japão, dos Estados Unidos, do Brasil todo. Tinha muita excursão e, hoje, as pessoas falam assim:

"Mas o teleférico..."

Os funcionários que eram responsáveis, mas não têm culpa alguma. Foi o povo que destruiu... Quebrou uma peça do teleférico que levava o pessoal lá em cima, então você lembra como eram a importação e exportação no Brasil? Terrível, não é? Demorada.

O teleférico parece que era de uma empresa italiana. Então, a peça era importada. O Antônio, que hoje eu não sei onde mora, que tocava aquilo lá. $A$ lanchonete, o teleférico. Sem saber o que fazer, o Sr. Antônio não tinha como levar o teleférico lá para cima sem o painel de controle. Não veio a peça e o Antônio tirou todas as coisas dele. Então sentamos todos e conversamos (eu, ele, o Toninho e todo mundo):

"Olha, estou fora! Já conversei, vou entregar as chaves." 
A partir do momento que o Antônio entregou as chaves, as coisas de inox - pias, umas coisas muito bem feitas - foram todas roubadas. Não é justo dizer:

"Ah! Foi a prefeitura que abandonou."

Agora, com essa reforma, reforçaram a segurança. Por isso que não estão mexendo. Porque senão já tinham dado um jeito de roubarem as grelhas. É a cabeça do povo, o que é uma pena. Do que eu vi, o que eu presenciei, o que nós vivemos.

Meus filhos andaram na fase experimental do teleférico; andavam o dia inteiro. Eu andei umas duas vezes, não sou muito de altura não, mas os meninos? Nossa! Foi maravilhoso, uma coisa assim... Trouxe muita gente para lá.

Mas eu só tenho que falar que para mim foi muito bom. É uma pena que roubaram tudo.

\section{E quando que vocês deixaram o parque?}

Nós saímos do parque no início de fevereiro de 1986.

\section{Nessa época o parque de lazer ainda funcionava?}

O parque continuou. Mas, aos poucos, o pessoal foi deixando de ir. Aos poucos, porque não tinha mais pedalinho, mas ainda colocaram uma jangada.

Depois do senhor José Batista (administrador), quem ficou no lugar dele foi seu genro. O Ari, que ficou por muito tempo. Só que, às vezes... ser muito franco é complicado. Na minha cabeça, quando se tem um aquário de peixes, o que é melhor? Conservar ou abandonar? Se quiser conservar e tocar adiante você consegue, mais se deixar... como a estação de embarque, o coreto, a casa do Tarzan, a gruta, que era a bica d'água; a gruta era a coisa mais linda! Em Santo André as pessoas pegavam água lá. Era de pedra. Então tiraram muita coisa. Muita coisa saiu do Parque do Pedroso, e é uma pena, uma pena...

O parque hoje está bem frequentado, principalmente depois que inauguraram a ponte. De lá para cá tem vindo muita gente.

\section{O parque tinha um controle de entrada? Tinha uma portaria? Era cobrado algum ingresso, alguma tarifa?}

(D. Maria) Nunca foi cobrado absolutamente nada. Só era estabelecido um horário de entrada e saída, isso sim, e o controle das quadras para usar. Teve uma época 
que era o Miguel quem fazia isso. As pessoas ligavam ou chegavam ao parque e reservavam a quadra. Alguns usavam a quadra o dia todo e os outros ficavam de fora. E foram assim os campeonatos de bocha, de pescaria, de truco.

\section{Quando a senhora trabalhou na lanchonete era na construção redonda grande?}

Isso, lá era uma lanchonete. Eu trabalhei por causa do acidente do Miguel $^{8}$, pois não tínhamos como sobreviver. Tinham algumas barracas lá embaixo, perto da bica. Meu marido dizia para jamais vender alguma coisa dentro do Parque sem autorização. Assim, ele não permitia que os filhos vendessem nada, de forma alguma. Então o que eu fiz? Eu simplesmente tinha que trabalhar. Não tinha como deixar meus filhos sozinhos lá em cima para ir trabalhar, embora eu fizesse alguma coisa - pão e salgadinho, que eu fiz muito para o doutor Sebastião, para a doutora Cenira, dentistas da Caixa de Pensões. Foi assim que fiquei conhecida entre eles.

Fui à igreja e peguei algumas moedas para comprar arroz para dar para os meus filhos. Então, prometi tanto que eu trouxe de volta. Cheguei lá em cima, como eu tinha meu fogão à lenha, fiz minha comida e dei para os meus filhos comerem. $E$ quando eu fui conversar com o senhor Nilton (pelo qual tenho muito respeito), ele disse:

"Dona Maria, quem sou eu para falar? A senhora está pedindo para trabalhar, não é? Quer trabalhar aqui comigo?"

Só que eu não tinha como deixar meus filhos lá em cima no meio do mato, sozinhos. Então, retirei os patos e os coloquei dentro da barraca do lago, dei comida para eles e fui vender doces para alimentar meus filhos e meu marido, que também precisava de alimento, e fui à assistente da prefeitura, na época doutora Marina, e procurei muitas pessoas para que me dessem a legalização para eu trabalhar lá dentro:

"Se a senhora não for funcionária da prefeitura, eles não vão deixá-la trabalhar aqui."

Então eu tinha medo de prejudicar a mim e ao Sr. Nilton. E o tempo foi passando e isso não se resolvia, e eu não tinha um centavo para comprar doce para vender. Então, o senhor Nilton comprou tudo e pôs na barraca e falou assim para mim:

"A senhora pode trabalhar e nós vamos dividir o lucro." 
Eu aceitei porque eu não tinha nada e, graças a Deus, foi por pouco tempo assim. Fizemos um acordo. Ele ficou doente e teve que se afastar, chamou-me e falou assim:

"Dona Maria, toma conta da cantina para mim, pois eu não tenho ninguém."

Nós passamos a trabalhar em todos os sábados, em todos os domingos, em todos os feriados, todo Natal e Ano Novo e nunca tivemos problemas com ninguém dentro do parque, nem com os funcionários.

Depois que Miguel passou pela cirurgia eu fiquei dois anos na cantina. Mas não deixei de vender as minhas coisinhas lá embaixo. Eu levava meu filho, que estava desempregado, e minha nora com a neta.

Eu não ganhei nada na cantina. Pois veja, tenho um caderno. Pode consultar aqui, o caderno é verídico. Eu pagava na época seiscentos reais para o senhor Nilton, porque ele também, penso que precisava. Então eu pagava e não sobrava, só para pagar os funcionários. E por que eu não fiquei lá? Daí eu falei para o senhor Nilton que eu ainda precisava trabalhar. Algumas pessoas falavam para mim:

"A senhora está falando que ficou aqui? Que morou dentro do parque? Que teve o parque nas mãos e está pobre?"

E eu falei:

"Graças a Deus! Porque tudo que eu tenho é meu, eu não peguei nada de ninguém e sou feliz por isso. Por isso eu vou continuar."

Então quando falaram para eu ir embora, fui até o prefeito. E na época eu conversei com o secretário, que era o "Vanders" [sic], que falou para mim:

"Dona Maria, se alguém chegar lá e falar para a senhora: 'pegue suas coisas e saia, primeiro a senhora deve ligar para mim".

E eu contei toda a história a ele e perguntou-me se eu cuidava do parque. Disse que sim, que eu cuidava. Enquanto nós moramos lá, nossos bichos não passaram fome, eu dividi com eles, e tenho orgulho de dizer isso!

Vocês que já moraram no parque por muito tempo, como vocês veem os moradores do parque de hoje? Na Olaria há alguns moradores bem antigos também, não?

\footnotetext{
${ }^{8}$ Acidente de trânsito, quando Sr. Miguel estava a trabalho, em 1983.
} 
As pessoas da Olaria são um caso à parte. São famílias boas, famílias simples. Pessoas que moram lá não sei há quantos anos.

(Sr. Miguel) Pegamos tijolos de lá [Olaria] para o Parque do Pedroso por uns trinta anos.

\section{Já existiam os moradores?}

Já existiam, sim. E os que estão lá hoje já estavam naquela época. Acho que o avô deles já estava lá. Foram anos, muitos anos. Como o pessoal do pinheirinho. Aquela mulher, a mãe dela já estava lá, sabe?

Eu acho que moram lá há mais de quarenta anos. Muito mais. Desde que fomos moradores do parque também.

Essas pessoas que estão dentro do parque, que respeitam o parque onde nós moramos, eram as pessoas mais antigas que preservavam. Eles não tiravam lenha da mata, se tirassem alguma coisa, era para fazer uma comidinha, pôr lá no fogão, e não para finalidades comerciais. Comércio de jeito algum! Na época em que o Miguel estava lá eles tinham jipe, faziam ronda pelo parque todo. Não deixavam pescar, nem tirar nada de dentro do parque. Era proibido desde o Montanhão.

Cresceu muito, não? O pessoal foi lá para cima e a Pintassilgo também cresceu. Acho que quem estava dentro do parque eram as famílias que conhecíamos.

\section{O que o Sr. Miguel acha disso?}

Acho que, como a área é muito grande, pode existir alguém que mexa na mata. Só precisa ter alguém "de peito" mesmo, com vontade de trabalhar e andar naquele mato. O carro tem que andar pelo mato, o fiscal deve cumprir suas obrigações; se não fiscalizar a turma começará a tomar conta de novo. Daí logo uma pessoa virá, derrubará uma árvore ali, outra aqui e assim por diante. Seria uma grande perda.

Acho que deveriam ser mais vigiadas as encostas aonde chegam as moradias. A Toledana formou-se rapidamente. Então, acho que isso devia ser mais vigiado para que moradias não invadam o parque. Pois as pessoas simplesmente vão entrando. Quando se dá conta, os locais já estão invadidos e descaracterizados e modificados. Parece que em outros países, há vigias dentro dos parques. Aqui já não sei se daria certo. Mas penso que poderiam haver, sim, famílias lá. Famílias 
que colaborassem com a preservação, como existiam antes. Não existia abuso. Por exemplo: havia o Sr. Luís e, depois de nós, o Sr. Antônio Gaudino.

Mais ao fundo havia um muro subindo a Estrada do Pedroso, depois da guarda. Ali tinha uma nascente e lá dentro daquele paredão, naquele muro, era uma escola. Era assim: havia uma parte de tijolos e outra de madeira. Só que meus filhos já não pertenciam mais àquela escolinha, porque já estavam na terceira e quarta série, e quando fomos morar lá que a escola veio para cá. Mais adiante tinha uma escola que mudou para o Parque Miami. Ali morava a família da Inês, cujo filho atualmente é dono da Paulimar. Todos foram criados em casa. E em frente, saindo do Parque do Pedroso pela portaria, havia duas casas. Uma era escola, e tinha uma casa, ao lado direito, onde morava um japonês, e, à esquerda, era uma escolinha. Somos desse tempo.

A casa era de madeira, mas era boa. Depois morou mais uma família (na última casa) e roubaram tudo o que tinha lá. Nessa casa havia de quinze a dezesseis caixas d'água, motor etc. Não acredito como se dá oportunidade e acontece isso! Você confia tanto numa pessoa, que não paga aluguel, e conquista o cantinho dela. Quando sai de lá, rouba tudo. É da mentalidade, não adianta. E quando eu saí, eu deixei as criações, porque eu fiquei com dó de sacrificar. Uns quinze dias depois voltamos para lá e não tinha mais nenhum animal. A cabritinha mataram dentro de um quarto da casa. Foi uma pessoa ou um animal. Uma onça não poderia ter sido, pois é típico desse animal levar sua presa para longe e não deixar restos no local.

\section{0 que as pessoas acharam do parque reformado. Elas comentam alguma coisa?}

(D. Maria) Todas as pessoas que vêm para o parque atualmente perguntam algo para mim ou para o Miguel. Eles acham a ponte maravilhosa e que sua segurança é excelente.

Mas não sei o que acontece. Quanto mais o pessoal estuda, menos aprende.

Eu sou uma mulher de 65 anos. Há cerca de 27 anos trabalho pelo parque. Vejo da seguinte forma: pela faixa etária do pessoal, percebe-se que eles já têm outra educação. Porém, a educação não está só na escola, mas sim, deveria estar, mais dentro das casas. É como jogar o lixo no chão de casa. Jogar lixo no parque é a mesma coisa. 
Nós fazemos questão de que o nosso lixo seja juntado e empacotado sem problema nenhum, mas há algumas pessoas que fazem questão de jogar lixo no parque.

O pessoal elogia bastante a ponte, as churrasqueiras estão muito disputadas, mas ainda falta muito para a mentalidade do povo. Para entender que o parque é para ser usado, não fazer ele de lixo. É para conservar árvores, pois aqueles canteirinhos foram plantados em volta do parquinho, as crianças levantam as florzinhas, mexiam na terrinha e se vê outros pisando... Então, é uma questão de mentalidade.

Eu acredito que daqui a trinta anos ou mais as pessoas vão olhar o parque, o verde, a água com outros olhos. E se não cuidar, não tem.

Mas o parque está lindo! Pelo que as pessoas falam, melhorou bastante. $E$ me perguntam se está pronto. Eu digo que não está. Pelo projeto que tem naquele livro, falta bastante. Mas o pessoal já está tendo mais cuidado, e a gente "pega no pé", viu? Quando, por exemplo, vemos uma pessoa que vai lá com gaiola, o Miguel não permite. De jeito nenhum.

Então, comunidade não é um pelo outro?

Eu cuidando, você cuidando, ela cuidando, é o que a gente faz.

É só isso que eu tenho a dizer. 
Aminadabe Belmiro Florêncio (Febem) 
Entrevistado: Aminadabe Belmiro Florêncio "Febem"

Local: Santo André-SP

Data: 06 de Junho de 2009

Duração: $22 \min 20 \mathrm{~s}$

\section{Antes de trabalhar no Pedroso, você já conhecia o parque?}

Não. Não conhecia o Parque do Pedroso, porque eu comecei a trabalhar no Parque do Pedroso em 1999, foi quando ganhamos a prefeitura ${ }^{1}$ aqui em Santo André.

\section{Gostaria que falasse do trabalho da fiscalização no Parque do Pedroso.}

O trabalho começou em 1999, meados de 1999-2000, quando eu comecei a trabalhar na prefeitura. Conheci o Sandoval, que era o fiscal naquela época. Ele saiu me mostrando as divisas do parque, o que era Ribeirão, o que era São Bernardo do Campo, e dizia:

"Essa área aqui é uma área pouco olhada."

O trabalho começou com o Sandoval. Nas vistorias, encontrávamos toneladas e toneladas de lixo, entulho, lixo industrial, produtos farmacêuticos e químicos, todos jogados nas bordas das nascentes, aonde o SEMASA faz a captação de água, até que, por um período, a água ficou contaminada.

Naquela época a fiscalização não tinha o poder de apreender caminhões - para multar -, e quando multava era uma multa bem irrisória, que os caminhoneiros davam até risada da gente. $\mathrm{Na}$ administração do Celso Daniel fui conversar e ele falou:

"Nós vamos mudar essa legislação."

E foi o que aconteceu. A Lei de Fiscalização na época era a $5.579^{2}$. Aí foram acrescentando alguns decretos e passamos a ter poder de apreensão de caminhões, com o valor da multa bem maior. Eu me lembro que só em uma operação com a Guarda Municipal, numa sexta-feira, prendemos 21 caminhões. Nós começamos a trabalhar cinco horas da manhã e terminamos à meia-noite.

\footnotetext{
${ }^{1}$ Mandato do Prefeito Celso Augusto Daniel (Partido dos Trabalhadores), de 1989 a 1992. De 1993 a 1996, Nilton Brandão (Partido Trabalhista Brasileiro). Novamente Celso A. Daniel, de 1997 a 2000, que foi re-eleito em 2001 e governou até 2002, ano de seu falecimento, quando assume o Prefeito João Avamileno (Partido dos Trabalhadores), que também foi re-eleito para um mandato até o ano de 2008.

${ }^{2}$ Lei municipal ${ }^{\circ} 5579 / 79$. Dispõe sobre o serviço de limpeza pública.
} 
Esse pessoal que jogava o lixo tinha que ir limpar, não é? Tinham algumas empresas que iam "varrer" até na área de manancial, porque nós os fazíamos "varrer" o lixo que eles tinham jogado. Foi aí que nós também descobrimos que a maioria do lixo não vinha de Santo André, mas de São Caetano do Sul, Diadema, São Bernardo do Campo, Mauá e São Paulo. De Santo André mesmo era muito pouco e eram as pessoas que nós apreendíamos. Então, nós começamos a fazer operações todos os dias e levamos mais ou menos dois anos fazendo essas operações.

Em alguns dias nós pegávamos sete, oito, até nove caminhões. Em outros, 10. E assim foi variando. E, depois, com o decorrer do tempo, e da ação da fiscalização, isso começou a diminuir até que nós apreendíamos um ou até nenhum infrator. Em algumas semanas, só três caminhões.

Até que chegamos em 2008, com uns dois ou três anos sem apreender alguém jogando lixo ali. Porém, a fiscalização deve ser mantida. Por que senão, o que acontece? O pessoal volta a jogar lixo.

Nós fizemos vários trabalhos dentro do Parque do Pedroso para a proteção das captações de água, para evitar que as pessoas jogassem lixo - onde eram descartados muitos cadáveres, rituais espíritas, descarte de carros roubados, barracos de invasão, caça ilegal predatória etc. Então, com todo esse trabalho que foi feito dentro do Parque do Pedroso, acredito que melhorou de $89 \%$ a $90 \%$.

\section{Quando vocês começaram a fazer as apreensões de carros, aquelas estradas internas ao parque já existiam?}

Sim. Desde quando começamos a trabalhar já existiam. Existia a Estrada do Sertãozinho e a Estrada do Montanhão, e como naquela época ainda não tinha a Lei do Meio Ambiente, ${ }^{3}$ os Prefeitos que vieram foram abrindo as estradas achando que estavam fazendo um bom negócio, e foi aí que causaram o maior problema dentro de Santo André.

$\mathrm{Na}$ administração anterior que deram uma virada, uma atenção maior para o parque. Foi quando nós começamos a fazer alguns trabalhos de fechamento de estradas, bloqueando entradas, começamos a restringir a entrada de carros dentro do parque, nós começamos a fazer alguns melhoramentos, mas a Estrada do Parque do Pedroso, a Estrada do Sertãozinho e a Estrada do Montanhão, na minha cabeça, tinham que fechar. Não podem ficar abertas. 


\section{Você conheceu os moradores de dentro do parque? Como você vê a relação dessas pessoas? É ruim ou bom eles estarem lá?}

Eu acho que todos precisam sair, pois o relacionamento daquelas pessoas com o parque, das pessoas que moram lá dentro, é de degradação.

Eles diminuíram, pararam de degradar por causa da fiscalização, porque começamos a "pegar no pé" porque eles caçavam, destruíam, juntavam-se com outras pessoas para caçar tatus para vender. Então, o relacionamento das pessoas que vivem lá é péssimo, elas têm que sair, porque não contribuíram com nada para o parque. Se os mantiverem lá vão continuar a destruir o parque, porque enquanto existir a fiscalização eles serão bonzinhos, mas quando a fiscalização virar as costas, estarão com estilingues debaixo do pescoço para caçar.

\section{Mesmo os moradores da Olaria, que estão há uns quarenta anos morando lá?}

Então, esse pessoal é o pessoal que trabalha na prefeitura, não é? Eu desde 1990 trabalho para tirar "esse povo" de lá, porque eles também foram os que degradaram o parque.

Pegamos muitas vezes os próprios funcionários caçando lá dentro. Moradores da Olaria. Então o relacionamento desse pessoal com o parque é ruim. Eu acho que eles devem sair. Eles são funcionários da prefeitura, recebem o salário deles, e o que acontece? Se a prefeitura não tirá-los, no futuro vai virar uma "Pintassilgo".

Você acompanhou, fez algum tipo de fiscalização na Pintassilgo? Como que era o controle que a Prefeitura e o SEMASA tinham naquela área?

A Pintassilgo começou em 1990. O grupamento ecológico foi construído naquele lugar por causa do núcleo Pintassilgo. Em 1990 e 1991 nós derrubamos vários barracos que as pessoas tinham construído. Ninguém, depois dessa ação, podia entrar lá dentro. Em 1992, nós saímos da administração.

Tinha apenas um barraco lá. Quando chegou a administração do Brandão foi permitido que as pessoas invadissem, e as que invadiram eram todos funcionários da Prefeitura.

O Grupamento Municipal parou de fiscalizar, não é? E o que aconteceu? Virou aquilo lá que está hoje. Mil duzentas e vinte e oito famílias lá dentro. E ai

\footnotetext{
${ }^{3}$ Lei municipal 7733/1998, que instituiu a unidade de conservação do Parque do Pedroso.
} 
pode-se observar, se quiser entrar lá: pelo menos $50 \%$ das pessoas são funcionários públicos da Prefeitura.

\section{E o Rodoanel? Você acompanhou desde o início a implantação do Rodoanel? Gostaria que contasse esse histórico. $O$ que aconteceu com o parque com a implantação do Rodoanel?}

Quando o Rodoanel chegou começou a fazer um monte de projetos passando uma parte dentro do Parque. E aí a briga foi grande com a administração. Brigamos muito, pois queriam entrar por dentro da Estrada do Montanhão e por dentro da Estrada do Sertãozinho e nós impedimos. Foi uma briga grande, mas nós conseguimos desviar.

Ele começa lá na Rua Mico-Leão-Dourado, lá embaixo dentro do Jardim Clube de Campo [sic], Recreio da Borda do Campo e pega uma parte, mas uma porcentagem muito pequena, do parque, que é onde já estava invadido pela favela Pintassilgo.

$\mathrm{E}$ assim, do meu ponto de vista, que não sou engenheiro, acho que o Rodoanel é um mal necessário. Porque fez algumas destruições, fez alguns desmatamentos, mas também ele trouxe muitos benefícios, porque retirou as construções ilegais. Havia muitas obras ilegais lá dentro.

Uma coisa que hoje vemos é que o Rodoanel fez grandes estragos. Mas com o trabalho de recuperação conseguimos deixar o parque novamente mais limpo, com menos residências próximas a ele. Assim temos mais condições de preservá-lo.

Com a Prefeitura e o SEMASA fiscalizando nós conseguimos fazer com que o Rodoanel não fizesse um desmatamento tão grande como foi feito em outras cidades. 


\section{Então, o maior acompanhamento da região foi feito por Santo André? São \\ Bernardo e Mauá não acompanharam tanto?}

No município de São Bernardo do Campo acompanhamos, sim. Mauá nós não acompanhamos muito. Acompanhamos apenas um trecho, mesmo porque ele entra só num pedacinho em Mauá.

Ele está mais em São Bernardo e Santo André. Em São Bernardo eles desmataram bastante; entraram e não derrubaram muitas casas. Não teve muita desapropriação como em Santo André. Agora, São Bernardo como estava na antiga administração, na administração $\mathrm{Dib}^{4}$, chegamos a fiscalizar aquela área que São Bernardo não tinha nem entrado ainda, e eles não tinham entrado em Santo André. Começaram a obra por São Bernardo. Então, por que nós fomos lá fiscalizar? Para que não acontecesse a mesma coisa que aconteceu em São Bernardo em Santo André, e reparamos que o estrago foi grande lá. Daí desmatouse muito. Eu não sei se em São Bernardo deixaram de fazer o que eles queriam. Mas eles viram que como nós já estávamos fiscalizando São Bernardo, para ver o que ocorria, sabiam que em Santo André, quando chegassem, iam pegar 'osso duro', como eles pegaram.

Até hoje estão construindo e qualquer problema que acontece a fiscalização 'está em cima'.

\section{Você conseguiu resgatar animais ou árvores? A prefeitura utilizou algumas árvores retiradas pelo Rodoanel? Como aconteceu isso?}

Fizemos um acordo para que árvores como Manacás, que fossem sair de lá, pudessem ser reaproveitadas. O Rodoanel passaria para o SEMASA ou para a Prefeitura, que reaproveitou muitas árvores, e o SEMASA também. Nós pegamos muitas bromélias, várias Samambaias-açú. Pegamos várias mudas para que pudéssemos transplantar. Muitas delas, dentro do parque.

Animais foram resgatados. Muitos bichos-preguiça, catitas, vários macacos, e nós levamos para dentro do parque, examinamos com nossos biólogos, para ver se estava tudo bem, e aí soltamos os animas de volta para dentro do Pedroso.

\footnotetext{
${ }^{4}$ Willian Dib foi prefeito de São Bernardo do Campo de 2004 a 2008 (Partido Social Democrático Brasileiro).
} 


\section{O viveiro municipal, dentro do parque, sempre foi um assunto conflituoso. Como era essa relação?}

O viveiro de plantas sempre esteve em conflito com a própria fiscalização, quando nós estávamos na prefeitura e agora trabalhando no SEMASA. Antigamente, o viveiro era uma horta, que produzia alimentos para a prefeitura. Eles plantavam alface, banana, tomate etc. Isso em 1990. Plantavam todos esses alimentos para servir à prefeitura e às escolas.

Depois começaram a produzir mudas para plantar na cidade. Mas desde a época do início da fiscalização que eu sou contra que o viveiro esteja lá, porque eles mexem com plantas ornamentais do tipo unha-de-vaca e outras mudas, para plantar na cidade, que não têm nada a ver com área de manancial. Então, o que pode acontecer? Um vento forte leva a semente que cai dentro do parque, daí nascerão árvores que não são nativas dentro da área.

E também as degradações que faziam dentro do parque. Eles ajudavam a degradar. Os funcionários não têm orientação nenhuma de como eles podem lidar com o parque, e nós já pegamos funcionários lá de dentro caçando, pescando em áreas proibidas. $\mathrm{E}$ mesmo com aviso à chefia dos mesmos, nenhuma providência era tomada. Então, nós estivemos "no pé" desses funcionários, porque se a gente os pegasse, levaríamos para o D.P., como realmente aconteceu. Levamos alguns para o D.P.

\section{O que você achou da reforma do parque de lazer?}

A reforma do parque realmente devia ser feita. Era necessária, porém com cautela. O parque foi aberto à visitação de uma forma descontrolada, pois as pessoas entravam com seus carros, por exemplo. Sempre fui contra a entrada de carros lá. Não que as pessoas não possam visitá-lo. Claro que podem, mas deve haver um controle disso. A exemplo disso temos as portarias. Deveria haver uma única portaria no parque, para que, com isso, fosse mais bem controlada a entrada e saída das pessoas.

\section{Depois de vivenciar diariamente o parque através do seu trabalho, mudou a sua percepção, sua relação com ele?}

A minha relação com o parque é muito especial, porque eu dediquei mais ou menos dezesseis anos de trabalho lá e eu acho que o Parque do Pedroso é o "pulmão" de Santo André. O Parque do Pedroso é uma área, que não só eu, mas 
todo o município de Santo André deveria cuidar com carinho, porque é o único "pulmão" que Santo André ainda tem dentro da área urbana.

Então, às vezes, eu até chego a brincar com as pessoas quando eu falo que o Parque do Pedroso é o Amazonas [sic], Amazônia de Santo André, que nós precisamos tomar conta, preservar, porque é uma área muito bonita, que o pessoal tem que passear e cuidar.

Então, eu gosto muito do parque. Ele é uma coisa que já faz parte de mim. Mesmo fora da administração, às vezes, eu vou até lá para ver como está.

Depois que eu comecei a fazer esse trabalho dentro do parque, e com o resultado que deu, as administrações começaram a dar mais atenção a ele, porque viram que o Parque do Pedroso tem muito valor. E que é preciso cuidar. 
Raul Isidoro Pereira 
Entrevistado: Raul Isidoro Pereira, Arquiteto Paisagista

Local: São Paulo-SP

Data: 05 de Junho de 2009

Duração: 1 h 27 min 35 s

\section{Como foi o processo de participação na construção do projeto do Parque do} Pedroso? Qual a expectativa da população? Quais relações você percebeu que estavam estabelecidas?

Primeiro falarei de quando aprofundei meus conhecimentos sobre 0 Parque do Pedroso. Fiquei muito impressionado com um parque daquele tamanho, com aquela beleza, bem preservado, em uma área de nove milhões de metros quadrados. É um espaço equivalente ao maior parque municipal da cidade de São Paulo e, no entanto, é pouco conhecido na capital. É uma área significativa, rica, relativamente preservada, uma preciosidade, que está contida mais na visão imaginária de Santo André e da região do Grande $A B C$ e não tanto na região metropolitana. Quando falo que fica próximo a São Paulo as pessoas não acreditam.

Sinto que há uma lacuna no pensamento mesmo dos andreenses, pois, pelo fato de o Parque do Pedroso não estar em uma região central, é tido como uma coisa do "povão lá do fundo", um lugar que os moradores do centro não vão visitar. Então, existe essa dicotomia que precisa ser quebrada.

Creio que há um dado muito importante na concepção do projeto que não foi concluído. Era mais amplo e estava articulado com a rede de educação na cidade inteira, tanto pública como privada. O projeto foi feito num prazo curto, porque precisávamos fazer um estudo básico com um programa ligado a agendas mais intensivas e, ao mesmo tempo, concluímos que o parque tinha que ser incorporado efetivamente pela população.

A visão que todos têm em relação ao espaço público é de que a população tem que sentir o parque como sendo dela. Percorrendo o parque com a $\mathrm{Bel}^{1} \mathrm{e}$ outros profissionais do SEMASA, tomei conhecimento de uma construção abandonada, um tesouro, uma interessante marquise modernista e pensei comigo:

\footnotetext{
${ }^{1}$ Izabel Maura de Farias Lawendovski, Diretora do Departamento de Gestão Ambiental do SEMASA gestão 2005-2008.
} 
"Parece uma obra daqueles arquitetos modernistas da década de 1970." Até dei um "chute": poderia ser do Ruy Ohtake, numa fase em que fazia uma arquitetura mais simples e mais despojada.

Subimos o morro e mais duas novas descobertas incríveis!

"Que estações são aquelas lá em cima, jogadas lá no mundo, deterioradas, aquela estrutura bonita de concreto, sem uso nenhum?" Então vimos uma coisa bem triste, que foi o rompimento da história do parque: as três estações teleféricas desativadas.

O modo como o parque é utilizado é variado. Uma coisa era ir ao sábado e ao domingo, outra era ir numa quarta-feira, por exemplo. São dois parques diferentes. No final de semana fica lotado, congestionado próximo às áreas esportivas, dos lagos, das churrasqueiras, que são "o restaurante" barato do povo e durante a semana, pouco frequentado.

Daí, lemos a história do Pedroso, e o teleférico foi um dos grandes pontos de atração na época, inaugurado na década de 1970. Nos anos noventa (1990), quando foi abandonado, não teve novo uso, e é como se fosse acabando com a história lentamente. É como se "com um facão" um pedaço importante do parque.

Fizemos o projeto a partir da obviedade que o projeto apresentava. Enquanto programa, tinha que ter um uso intensivo naquela área e a intenção era não avançar em áreas ocupadas por mata, mas trabalhar onde já estava desmatado.

$\mathrm{Na}$ verdade, o objetivo do projeto foi requalificar os espaços que estavam mal resolvidos e inadequados e recuperar as construções de Ruy Ohtake, atualizando os usos.

\section{Vocês procuraram saber da possibilidade de revitalizar o teleférico?}

No SEMASA, conversamos com a Bel e sua equipe a respeito.

"Bel, não há possibilidade de recuperá-lo e retomá-lo em moldes mais modernos"?

A prefeitura não tinha verba e custava, na época, seis milhões de reais. Então, a ideia foi continuar com o maquinário remanescente, transformando-o numa coisa meio museológica, e o espaço teria outro uso. Tanto que, à época, não quis mexer muito naquela marquise sem o aval do Ruy Ohtake. Limpamos totalmente o que hoje não teria mais função - o bar e a bilheteria - e deixamos só o banheiro. 
Abrimos todo o visual para aquele lago, que é maravilhoso, e ele concordou com as alterações.

Qual foi a ideia estruturante do projeto? Acho que esse é um ponto importante. Tem-se um parque que é uma preciosidade, mas que está isolado da estrutura urbana central de Santo André. Pelo menos no imaginário, na vida da cidade como um todo, ali é uma passagem para quem vai ao Parque Miami ou para outros lugares, e quem o frequenta são os moradores do entorno. O parque, portanto, é uma ilha, quando deveria ter um caráter metropolitano, não somente em relação a Santo André, mas também à Grande São Paulo. Como se faz para as pessoas serem conectadas e terem vontade de frequentar um parque com esse perfil?

Para a classe média, que mora no centro, com todo aquele esquema de Shopping Center, fica fácil ir ao Parque Ibirapuera, ao Villa-Lobos, e há uma força centrífuga que puxa para fora, para São Paulo.

Mas acredito muito que é possível mobilizar esses moradores a virem ao parque através de uma ação sistêmica nesse processo, ou seja, algum elemento, físico ou virtual, que conecte com a rede urbana, pelo menos em Santo André. Então, nossa ideia foi: um parque que fosse um "centro educacional". Não sei se chamaria ambiental. O centro seria instalado onde hoje é o viveiro de mudas e estaria ambientalmente ligado a todos os outros recursos do parque, como os corpos d'água, os bosques, as praças, e seria uma estrutura arquitetônica leve e espacialmente livre, que conectasse com todas as escolas da rede de Santo André dentro daquela ideia da Fruta no QuintaF. Um processo via internet que, a partir do parque, poderia conectar realidades ligadas a ele; acessando o site dele para saber como é o abastecimento de água de uma cidade, por exemplo. Não aquela fórmula "meio chatinha" de educação ambiental acadêmica. Seria mais ao estilo do Museu da Língua Portuguesa, em São Paulo. Lembrei-me inicialmente do MOMI - Museu de Cinema em Londres -, que é muito interessante. Logo que entramos no museu, há o Carlitos ${ }^{3}$ ou outro personagem do cinema, que nos recebe para tomar um café. Em seguida, caminhamos para uma salinha, que é como uma câmera fotográfica interativa, deitamos num sofá para ver projetado um filme no teto e, desta forma,

\footnotetext{
${ }^{2}$ O projeto Fruta no Quintal, de autoria de Raul Isidoro Pereira e Caio Boucinhas, foi desenvolvido para a rede escolar do Município de Diadema e tinha como pressuposto o desenvolvimento de atividades com professores e toda a comunidade escolar para ações de reabilitação e transformações dos espaços livres escolares e da cidade.

${ }^{3}$ Personagem principal do cineasta, ator e compositor Charles Spencer Chaplin Jr. (1889 - 1977), que marcou o cinema mudo no início do século XX.
} 
aprendemos sobre a história do cinema teatralmente, um processo semelhante ao do SABINA ${ }^{4}$.

Além dos belos atrativos naturais e das atividades culturais que o Parque oferece, passa a funcionar como um pólo conectado com a rede escolar, dentro de uma programação e agendamento que o torna um elemento vivo e dinâmico para a cidade.

Bem, então como vejo? Com os meios de comunicação, dos quais antes não dispúnhamos, as pessoas seriam atraídas para um novo lugar que, além do verde, possui algo que Santo André ainda não possui em termos ambientais. O que de certa forma é bem triste é ver que simplesmente toda a água, a mata e a beleza do parque não são suficientes para a classe média deslocar-se, levar o filho sem achar que será morto no caminho, com aquela visão de onde há pobre há violência, aquela coisa preconceituosa.

Então, criaria um novo espaço, e esse foi um dos pontos fundamentais do projeto. Mas seria uma segunda etapa, que na fase atual da construção não entrou como elemento estruturante do projeto. Mas no meu imaginário continua aceso.

\section{Aonde seria o local do Centro Educacional?}

Seria onde é o viveiro atual. Seria combinado com o DPAV ${ }^{5}$. É um lugar que tem uma qualidade interessante, tem áreas já desmatadas, com construções, e na beira do lago, o que é maravilhoso, e seria uma forma de fazer todo mundo atravessar o parque para chegar até lá.

O programa que nos foi dado tinha que prever estacionamentos dentro do parque. No final de semana é um carro em cima do outro, uma coisa impressionante. Carros misturados com gente, com churrasco e as crianças brincando. É uma coisa confusa por um lado, mas rica em termos de vitalidade e uso do espaço público.

\footnotetext{
${ }^{4}$ SABINA - Escola Parque do Conhecimento -, um centro de educação e ciências do município de Santo André.

${ }^{5}$ Departamento de Parques e Áreas Verdes, vinculado à Secretaria de Obras e Serviços Públicos da Prefeitura de Santo André.
} 
Isso foi alterado. Depois que liberaram o acesso pela ponte, os carros deveriam estacionar no estacionamento da Estrada do Pedroso, não entrando mais dentro do Parque.

Por isso que foi legal essa ponte, porque não só permite o acesso do pessoal que mora naquela região para dentro do parque, como também faz com que deixe o carro lá fora. Libera-se aquela área, perto da igreja, que é uma das mais preciosas. Lá existe um riacho que pode ser descanalizado e ficar a céu aberto. É um lugar muito mágico e a Administração tem que ter um projeto arquitetônico bonito, porque é um ponto sagrado para a população.

\section{E sobre a participação?}

Um projeto participativo pode ser feito de, pelo menos, duas maneiras: fazer um estudo preliminar e levar para a população aprovar, ou não; ou fazer o contrário, uma pesquisa primeira, uma conversa e, depois, desenhar. Mas o prazo era muito curto, não tínhamos prazo para nada, então ficamos pensando como fazer. As oficinas faziam parte da licitação de técnica e preço, o que já é um passo importante.

A metodologia foi pensada por nós da seguinte maneira: tínhamos um trabalho já feito e, se mostrássemos já de início, estaríamos de certa forma sugestionando a população. Por outro lado, não mostrar, não achávamos correto. Então, foi apresentado um mapa básico com a seguinte pergunta:

"O que vocês acham que deveria ser feito no parque?"

"Nós, da equipe de projeto, elaboramos uma proposta geral. Então vocês vão falar o que é necessário, o que gostariam e o que não gostariam, e depois no final vão desenhar. Em seguida, a gente acrescenta nossa proposta e juntamos tudo." E assim surgiu o terceiro projeto, que foi a síntese de todas as propostas.

Foi muito legal, pois as seis equipes desenharam e houve uma participação muito interessante - e antes fizemos uma visita ao local. Na hora saiu muita coisa que não foi planejada. Foram juntados os grupos e a proposta foi exposta. Felizmente, quase tudo que pensamos eles queriam que houvesse, como, por exemplo, a ponte e outros equipamentos, e, num ponto, foram unânimes: a ideia da retomada do teleférico.

$\mathrm{Na}$ assembleia a discussão foi bonita:

"Queremos o teleférico novamente. Já andei muito nele... e foi com ele que se inaugurou o parque" etc., argumentaram. 
Esclareceu-se que em função da pouca verba ${ }^{6}$ disponível, sua reinstalação seria difícil. Quem sabe um dia seria possível com patrocínio? Não poderia ser um preço alto. Como a empresa que iria operar o teleférico iria sobreviver? Teria que bancar por muitos anos com que atrativo comercial? A não ser que o parque passasse a ter uma visibilidade mercadológica, que hoje não tem. Então, patrocínio não é fácil, a verba não existe, e eles começaram uma discussão:

"Mas não se pode cobrar mais?"

"Cobra uma 'taxinha'!"

Foi uma discussão boa. Mas no final a decisão da maioria foi que nessa primeira etapa fariam o que fosse possível e, futuramente, talvez acontecesse.

O rompimento da história causa uma cisão no pensamento da paisagem em pouco tempo e não se acaba com uma coisa impunemente. Há uma questão subjetiva de alguém que, àquele tempo, passeou no teleférico com o filho, de outro que levou o pai junto e assim por diante. A história é interrompida e, de repente, acaba com um dado que não é somente a questão ambiental, que lá é fortíssima, mas com um elemento lúdico, que dava função para aquelas formas do Ruy Othake. A ideia foi de transformar a segunda estação do teleférico, da encosta do morro, num restaurante e fazer uma trilha no meio da mata. A visão que se tem de lá de cima é deslumbrante: aquela mata e as águas são lindas, com as quaresmeiras, as acácias e os manacás da serra colorindo os morros.

Esse parque é uma viagem! Conheço poucos em São Paulo que tem essa "coisa meio mágica" e essa delicadeza.

Foi uma época em que muitas cidades possuíam teleféricos e fontes luminosas e o teleférico era uma verdadeira "viagem", como hoje são os playcenters e não havia a internet com suas navegações virtuais. Aquela era a nossa viagem, juntamente com o cinema.

Agora é incrível ver o mapa do Pedroso. As nascentes estão todas contidas dentro do parque. $O$ traçado do parque não é um traçado mecânico, de um vizinho que vem aqui e outro vizinho ali e onde passo uma reta. Hoje seria a coisa mais óbvia, com os levantamentos e planejamentos feitos por bacias hidrográficas. Tem-se essa delicadeza, um dado físico de tipologia e visão de paisagem muito interessantes para a época, e isso criou condições para manter limpa toda aquela água do parque.

\footnotetext{
${ }^{6}$ Orçamento fixado pela Prefeitura de Santo André e SEMASA para a revitalização do Parque Natural do Pedroso.
} 
Nas oficinas realizadas, onde os moradores são meio "urbanistas", houve depoimentos muito interessantes. A discussão da proposta da ponte foi acalorada e o grupo que teve a ideia correu aos outros grupos para fazer lobby para a aprovação:

"Vamos propor a ponte, vamos propor a ponte!"

A questão das churrasqueiras também foi um ponto importante. Quando a Elaine $^{7}$, que acompanhou a elaboração do projeto, fez o levantamento, havia noventa churrasqueiras, que reduzimos para 57 , excluindo algumas que estavam sob as árvores. São equipamentos fundamentais nos finais de semana, onde o povo já leva as bebidas e as carnes preparadas e não tem gasto com restaurante.

Projetamos algumas churrasqueiras coletivas, mas a maioria prefere as individuais.

Bom, outra questão era que eles nadavam no lago e não é permitido, uma vez que a água abastece a cidade. Há uma foto com quarenta jovens e crianças nadando junto a uma placa do SEMASA com os dizeres "É proibido nadar". Isso cria um conflito em relação ao projeto: imagine uma criança de oito ou nove anos frente a toda aquela imensidão d'água, aquele lago maravilhoso, e não puder nadar! É uma frustração para quem visita um parque desses. O projeto criou brinquedos d’água em suas margens, em terra firme, mas ainda foram insuficientes. Poderia ter reservado uma parte do lago, como uma piscina, mas monitorado, pois, pelo projeto, além de sua função original, o lago é mais um elemento de contemplação.

\section{Isso motivou o uso da água nos brinquedos?}

Motivou. E ainda achamos que é insuficiente. Teve todo o circuito de brinquedos d’água, que possuem chuveirinhos, esguichos, cursos d’água, mas é diferente, e o gostoso mesmo é mergulhar no lago.

\section{Faltam opções para eles (população).}

Particularmente ali.

\footnotetext{
${ }^{7}$ Arquiteta Elaine de Moraes, do Departamento de Gestão Ambiental/SEMASA.
} 
Gostaria de abordar outros aspectos dos objetivos do projeto paisagístico para o parque (uma unidade de conservação), que são a preservação e a evidência dos recursos naturais. De que forma isso se estabeleceu no projeto e qual a relação entre esses dois aspectos (conservação e lazer)?

Primeiro há uma questão que se coloca em relação à proteção ambiental, que é aquela ideia que está no projeto de que é o uso que garante a manutenção do parque.

É, portanto, um uso diferente, de caráter distinto daquele da "preservação pura" numa área de um Parque, por exemplo, de reserva biológica, onde não se pode entrar. É um trabalho complicado conciliar recursos tecnológicos disponíveis para reduzir o impacto. Não podemos tirar a permeabilidade do solo... etc. Que tipos de eventos podem se realizar? Qual a capacidade de suporte? Em uma reserva biológica, imagine, de repente, um show dos Titãs! A programação tem que ser mais delicada. Existem áreas de uso intensivo, porém, compatíveis com uma unidade de conservação. Não se trata, portanto, de um parque como o lbirapuera! Há matas e lagos, mas é outra realidade. Isso é o diferencial da unidade de conservação: tem que haver atividades de baixo impacto.

O parque é muito rico em recursos hídricos. Tem-se uma nascente aqui, de repente o curso d’água some e, de novo, surge uma "aguinha" ali, que vem canalizada de uma área belíssima. Então abrimos o máximo que pudemos. Por exemplo, na área do campo de futebol, que vai dar lá para o segundo nível, lá para as antigas canchas de bochas, existe um regato que é maravilhoso! E está lá no fundo da quadra, escondido, e vai embora, é canalizado e some!

Por que procuramos trazer à tona? Para mostrar que aquele parque é a paisagem água! O elemento que estrutura, a ideia-força, é a água!

Aliás, é uma coisa presente na ecopedagogia, onde a água deveria ser o elemento estruturante. Que a água deveria ser algo que tomasse a conta de lá! Seria um tema para o SABINA. SABINA da água do Pedroso! Pode ser um elemento que não se limita à Região Metropolitana de São Paulo, mas para todo o Brasil.

Poderiam ser criadas conexões com as áreas mais centrais da cidade. Quando fazemos o percurso do centro de Santo André para o Parque do Pedroso vamos passando pelos bairros e, de repente, entramos no Pedroso e essa passagem poderia ser mais suave, mostrado como se fosse uma música. Pode-se ir a um lugar importante sendo importante já no caminho. Não sei se pela mudança 
da paisagem, pela arborização... Não sei como, mas é equivalente a chegar às Cataratas do Iguaçu por uma "portinha de cozinha".

Creio que é uma questão de escala da conexão, uma coisa mais concreta, como se o Parque do Pedroso tivesse que dominar a cidade e não ser simplesmente uma fonte de abastecimento de água.

Depois que foi reinaugurado, estima-se que esteja recebendo 4.000 pessoas por final de semana.

Que interessante! Porque a média antes era de mil pessoas por final de semana.

Está ultrapassando a estimativa adotada para o dimensionamento da rede de esgoto: três mil pessoas diariamente.

E pode aumentar bem mais e ser otimizado durante a semana e a escola deveria fazer esse papel. A prefeitura poderia comprar dez ônibus que circulassem o dia todo pela cidade, para as escolas, aquela ideia da cidade educadora. Porém, os alunos não saem muito da sala de aula, e sei que é difícil, pois os professores ficam receosos com a responsabilidade pela segurança dos alunos. Seria interessante o parque funcionar com programações que fazem com que ele se mantenha sempre vivo, que é diferente do parque com atividades meramente espontâneas. Isso exige uma gestão intersecretarial. Envolve a Educação, o SEMASA, o Parque Escola. E acho que hoje estamos num momento político em que questão ambiental está fortemente em pauta.

Pegando o exemplo em Seul ${ }^{8}$. Há dois anos, o prefeito quebrou um "minhocão", descanalizou o rio, transformando o local num espaço deslumbrante. Havia resistências: os comerciantes, os moradores do entorno estavam preocupados com o comércio (com a inauguração do parque linear no local onde havia um viaduto). As pessoas passaram a vender o dobro, aumentou o turismo, a população passou a frequentar o local como área de lazer. Foi uma mudança de tanto sucesso que o prefeito de Seul elegeu-se presidente da república. Portanto, temos quer ser mais radicais e ousados em certos projetos para a cidade.

\footnotetext{
${ }^{8}$ Seul, capital da Coreia do Sul.
} 
Mesmo o Parque do Pedroso estando em área urbana é objeto de críticas em relação às características urbanas que adquiriu com a implantação do projeto: guias, sarjetas, pavimentação asfáltica; e também espécies exóticas no projeto paisagístico. Gostaria que você abordasse estas questões.

É uma questão que divide também os habitantes. Não é incompatível, ao meu entender, uma enorme unidade de conservação, com aproximadamente nove milhões de metros quadrados, com um diálogo com elementos mais antrópicos, de alta tecnologia.

Não penso que seja necessário integrar, com uma visão de que a arquitetura é somente uma continuidade e decorrência direta do espaço natural. Nisso, o Movimento Moderno possui alguns exemplos interessantes. Mostra-se que a natureza não é incompatível com a obra de alta tecnologia, mesmo se, em muitos casos, causa uma estranheza à primeira vista. Tudo depende de como trabalhamos com o programa de necessidades, com os materiais, com as formas e com o respeito à cultura do lugar.

A Casa de Vidro, da arquiteta Lina Bo Bardi, é muito interessante, como exemplo. É muito bonita porque a arquitetura da casa é bem geométrica, mas o jardim é um jardim caipira e nos sentimos como se tivéssemos na roça, num quintal de uma cidade do interior, no qual ela e o marido, Pietro Maria Bardi, foram plantando, pouco a pouco, espécies nativas, misturando tudo, sem uma lógica mais organizada como a do Burle Marx. Há um caminho tortuoso de pedra, um galinheiro, horta, é uma obra totalmente antropizada, com um desenho e, ao mesmo tempo, um espaço naturalista. Acho isso uma aula de arquitetura e paisagismo e que mostra que, com talento, linguagens aparentemente opostas, podem ser harmoniosas.

Não penso que o projeto para o Pedroso, que é um parque totalmente natural, possa ter somente coisas de sapé ou de madeira. Pode-se usar a madeira de uma forma contemporânea e é uma questão inerente à atividade dos arquitetos, a da linguagem.

Há uma questão que foi um drama: o que acontece com a ciclovia? O ciclista não gosta de piso intertravado, porque provoca uma certa trepidação. Chão batido exige muita manutenção, mas seria o ideal. Quando há muitas áreas de APPs (Áreas de Proteção Permanente), em que a topografia não é plana e o solo não é firme, pelo problema de erosão, não se pode ter o piso de chão batido em todo percurso. A opção por asfalto era por ser confortável para circulação e de fácil 
manutenção, mas fatalmente se criaria uma área impermeável e consideramos que seria insignificante em relação à grande extensão do parque todo. Outra opção seria o piso intertravado, que ilusoriamente muitos acham que é permeável, mas na verdade permeabiliza apenas uns 15\% (quinze por cento), mas é de fácil execução e reposição e acho ótimo ser utilizado em outras situações.

Tem-se que compensar ambientalmente. Há uma "perdazinha": colocou-se um piso impermeável, mas em compensação será uma área em que as pessoas vão poder circular olhando distraidamente para a paisagem e não preocupadas se irão tropeçar ou escorregar. E isso também não é um ganho de qualidade ambiental? No meu entender, meio ambiente não é só água limpa, verde e ar puro, mas também é prazer, satisfação e conforto nas relações sociais e das interfaces dos humanos com seu espaço físico e isso muitas vezes não é facilmente mensurável pelos caminhos aritméticos. A questão que surge frequentemente é o conflito, ou o pseudo-conflito, entre natureza e cultura. E cultura a que me refiro é no sentido antropológico, no sentido de tudo aquilo que os humanos produzem, tanto os artefatos físicos como os bens imateriais. Há algumas práticas que deixam áreas impermeáveis com piso. Essa era uma prática das praças da Idade Média e do renascimento: havia a conexão com as cidades, e era algo totalmente imbricado e integrado.

Não vejo o piso pavimentado como uma perda. É um ganho! Arquitetura também é ganho. De fato, precisamos contrabalançar, mas há áreas que precisam ser impermeáveis e não é uma concessão, um favor que estamos fazendo para o parque, mas é um dado do programa.

Não vejo como contraditória a arquitetura, modernista ou não modernista, com uma linguagem mais contemporânea ou da área que se tenha pavimentação, em relação às áreas mais naturalizadas. Levar mais pessoas, confortavelmente para conhecer o parque é um ganho para a natureza, não é uma perda! Perderá alguns metros quadrados de área permeável, que represente um grão no oceano, e é um impacto pequeno em relação a tudo aquilo que o parque ganhará com sua requalificação, seu enriquecimento arbóreo, com a recarga do lençol freático e qualidade das águas. O carinho maior que a população passará a ter pelo parque é um ganho inestimável.

Vejo a obra do Ruy Ohtake daquele período da década de 1970, da construção do teleférico, de uma integração com a natureza muito delicada, no modo como a marquise se abre para aquele lado da paisagem, com apenas dois 
bloquinhos: um banheirinho no canto e uma lanchonete (demolida), d'onde no fundo se descortina o lago... Com um material durável, que é o concreto.

\section{Gostaria que falasse sobre as espécies exóticas presentes no projeto paisagístico.}

Trabalhamos fundamentalmente com espécies nativas, considerando que a espécie do local já está adaptada e presente na memória vegetal da paisagem, no imaginário da população. Isso é algo que sempre batalhamos e sempre colocamos em primeiro lugar. Sempre priorizamos espécies nativas, mesmo nos jardins menores. Porém, também utilizamos uma pequena porcentagem de espécies exóticas mais adaptadas, ou espécies de ecossistemas semelhantes.

Cerca de $90 \%$ dos alimentos que comemos são de espécies exóticas: arroz, feijão, batata, trigo, banana, manga... Se formos eliminar isso, não vamos plantar mais nada nas lavouras brasileiras. Numa área central de São Paulo, por exemplo, ao se plantar uma árvore, com o sub-solo compactado, tem-se água contaminada, solo contaminado, fiação elétrica, todos os impactos mecânicos das pessoas e carros. O clima, a temperatura, o grau de umidade se alteram num grande centro urbano. Os ventos enlouquecem dentro de um ecossistema, como o que Anne Winston Spirn falava: a cidade é um ecossistema diferente.

Nesse sentido, se trouxermos para o meio urbano uma espécie que estava, em conjunto, no meio da mata, ela sofrerá porque terá outra realidade. $\mathrm{O}$ ligustro (Ligustrum lucidum), por exemplo, é uma árvore muito resistente à poluição urbana. Vamos deixar de usar o ligustro porque não é espécie nativa? Não vai mais plantar banana no seu quintal por que não é espécie nativa? Então, aprendi com um agrônomo do $\operatorname{DEPAVE}^{9}$, que, a rigor, deveríamos estudar mais detalhadamente São Paulo inteira e analisar cada microecossistema, onde há áreas de várzea, áreas de morros e as demais conformações. Dentro dos vários ecossistemas diferentes, se quisermos plantar uma árvore nativa do lugar específico, tem-se que estudar como era a vegetação originalmente, porque em área de várzea, por exemplo, só determinados tipos de árvores podem ser utilizadas. E como fazer um estudo criterioso considerando-se que a natureza foi alterada? Não se tem mais o que se tinha naquela época. Talvez um pouco do solo remanescente ou o clima que mudou, mas não tanto. Então, penso que não podemos ter uma ideia dogmática em relação às espécies nativas.

\footnotetext{
${ }^{9}$ Departamento do Verde e do Meio Ambiente do Município de São Paulo.
} 
Temos o exemplo de Burle-Marx ${ }^{10}$, que fez o jardim tropical em Areias (SP), na fazenda Vargem Grande, onde $80 \%$ das espécies do jardim são exóticas. Se eu não conhecesse as plantas e chegasse lá de surpresa, acharia que é um jardim tropical brasileiro. Nosso maior e genial paisagista e defensor de nossas plantas fez um jardim e trouxe uma realidade ao nosso sistema que era de outro lugar, com a mesma linguagem e com espécies adaptadas.

E tem um dado que sempre fico pensando:

O passarinho pega uma plantinha daqui e leva para lá, o vento faz com que dissipem, a abelha poliniza, e os humanos? Foi-lhe dada uma condição, de viajar pelo mundo inteiro, levando mudinhas e sementes para outros lugares.

E ser humano não é natureza? Será que não pode se colocar em cooperação, com o passarinho com o pólen e com o vento?

Vendo a listagem de plantas nativas sugeridas pelo DEPAVE, não consta o Jacarandá Mimoso, que é da Argentina, Paraguai e Bolívia, países próximos daqui, mas se permite plantar o Açaí da Amazônia, que está a 3.000 quilômetros porque está dentro do mapa do Brasil. Então, eu não estou levando em conta o meu ecossistema, e São Paulo não tem muito mais a ver com o Paraguai do que com a Amazônia? As plantas não conhecem os mapas geográficos.

\section{Referente ao projeto de Ruy Ohtake, na sua avaliação, nesse projeto havia alguma premissa ambiental? Para o projeto do Parque do Pedroso houve alguma coisa que foi trazida do projeto anterior?}

$\mathrm{Na}$ verdade, conheci pouco o projeto do Ruy Ohtake. Na conversa que tivemos ele mostrou um caderninho que continha os esboços originais de um zoneamento maior para aquela região. Talvez houvesse informações interessantes sobre o projeto, mas quando fizemos a reunião, ele já estava elaborado.

O que assustou a todos, e a Bel, que é bióloga, era aquela ideia do zoológico dentro de um fosso, mas posso estar sendo leviano nessa análise, porque precisaria me aprofundar mais no projeto do Ruy Ohtake. E é importante entender a concepção dele na época, a visão que o Movimento Modernista tinha em relação à paisagem, o que também é uma questão delicada. Sobre o Movimento Moderno, estou me referindo mais ao do Le Corbusier ${ }^{11}$, que era defensor de uma arquitetura internacionalista. Há vários outros arquitetos que

\footnotetext{
${ }^{10}$ Roberto Burle Marx (1909-1994), Arquiteto Paisagista e Artista Plástico.

${ }^{11}$ Charles-Edouard Jeanneret, conhecido por Le Corbusier, Arquiteto (1887-1965).
} 
pensavam o modernismo de forma diferente, que afirmavam que o contexto e a cultura local também fazem parte da história e têm que ser incorporados no projeto.

O que sinto hoje em relação a muitos arquitetos com quem trabalhamos é que no campo do paisagismo ainda existe uma dicotomia entre o edifício e o espaço externo. É uma dificuldade. Existe a torre, a edificação. A arquiteta Silvia Dobry fez um desenho interessante, que é o edifício voando. Ele cai no espaço, como se o edifício pousasse de repente. Não que eles não pensem no todo! Mas não pensam com todo o cuidado que deveriam pensar.

Seria interessante ver qual era a concepção do projeto do Ruy Ohtake naquela época, colocando-o no contexto histórico em que a questão ambiental não se colocava tão fortemente como hoje.

Afetividade não é só em relação ao parque. Afetividade é em relação à cidade onde se mora. É uma coisa muito marcante quando vamos a um bairro como Jardim Ângela, onde não há árvore nenhum no barranco e, mesmo assim, os moradores não gostam que se fale mal do bairro. Não são somente as condições do espaço físico que contam. Independentemente do espaço, tem-se uma história embutida: os amigos moram ao lado e juntos percorreram o caminho para a escola, subiram naquela árvore, conheceram e passaram naquele barzinho, naquela padaria, tomaram café, jogaram bola, e isso são fatos que se relacionam com a geografia, com o universo, independentemente de ser bonito ou feio. Se fosse assim, eu não gostaria de São Paulo, que é uma cidade feia, concorda? Há um fator que é subjetivo, mais do coração que da cabeça.

O Pedroso é outra questão e é como se nos transportássemos para o meio rural. Acho que há uma coisa que vai além do caráter afetivo de moradia. Há o afetivo de um religamento com o universo natural, que se perdeu muito nas cidades.

Uma coisa minha que tem a ver com isso:

Eu fui embora de Presidente Venceslau quando tinha 17 anos, de trem, porque na época não eram os ônibus que faziam esse percurso. Lá, como em qualquer cidade pequena, na década de 1960, não havia o problema da violência, dava para percorrer a cidade e nosso quintal era a cidade inteira! Tem-se uma inteireza com as pessoas, com o universo que é muito menos impessoal que na cidade de São Paulo.

Ontem falei uma coisa interessante na palestra sobre a simbologia da vegetação, nativas ou não nativas, já que esse é um tema recorrente. Temos o 
exemplo do Brasil. Burle Marx, nosso grande mestre e referência, que fez um projeto de uma pracinha, em Tiradentes, Minas Gerais, uma das cidades mais lindas do Brasil e retirou umas casuarinas, árvores exóticas com cara de árvores de natal, e plantou guapuruvu, que é uma espécie nativa do Brasil, e a população ficou muito revoltada.

Independente de ser nativa ou não, elas faziam parte da história da cidade! Quando se chega numa cidade que não é a sua tem que se ajoelhar, retirar os sapatos, entrar com cuidado, com muito respeito, com humildade, entender e depois propor, junto com os moradores.

Não necessariamente o projeto será o que eles querem. Podem até concluir que aquilo que está sendo proposto é inovador, mas eu acho que essa passagem tem que ser respeitada. 
Ronaldo Antonio Linares 
Entrevistado: Ronaldo Antônio Linares

Local: Parque Natural do Pedroso - Santuário Ecológico, Santo André-SP

Data: 23 de Junho de 2009

Duração: 1 h $24 \min 10 \mathrm{~s}$

\section{Qual é a história do santuário? Como ele surgiu?}

A história do santuário está ligada à história da Federação Umbandista do Grande ABC. O umbandista e o candomblecista têm na natureza o seu altar. Nós aqui tentamos nos aproximar dos dizeres de Leon Diniz:

"Tende por templo o universo, por altar a consciência, por imagem Deus e por lei a caridade."

O umbandista tem por altar a natureza, antes de mais nada. Veja bem, como consequência do período colonial brasileiro nasceram duas formas diferentes de religião. Hoje as religiões são chamadas de afro-brasileiras. Porémm, o candomblé tem mais raízes afro-descendentes, enquanto a umbanda tem alguns elementos do africanismo. A umbanda é verde e amarela, é brasileira e não africana.

No período colonial brasileiro, tudo era feito às ocultas, as casas não tinham forro e até as intimidades da família muitas vezes eram feitas no mato. É uma questão de tradição. Os escravos, o segmento mais simples da sociedade de então, viam como os brancos faziam, como acontecia com os brancos. Eles não podiam fazer o que os brancos faziam por sua própria condição de escravos e, muito cedo, o escravo se deu conta de uma coisa: o que eles tinham em comum?

As cabeças pensantes escravas, a cor da pele, a origem africana, certo? A crença nos orixás, com exceção dos negros muçulmanos, os mandingas, principalmente do norte da África. Então, se eles quisessem voltar um dia a serem livres, não poderiam perder a sua cultura, a sua língua e, principalmente, a sua religião, que era um fator determinante. Mas a igreja católica medieval chegou aqui e impôs sua religião. Aliás, todo povo dominante impõe ao povo dominado seus valores. Então, o escravo teve que trocar de nome, de crença.

Uma curiosidade: por que tinham tantos negros chamados "Benedito"? Porque era a palavra mais repetida na missa em latim: benedictun Deus onipotente. Então Benedito devia ser uma palavra tão sagrada que talvez os livrasse do chicote, do lapido, compreende? 
Isso veio de geração em geração, mas a umbanda não existia como um todo. Os negros eram em maior número que os brancos e, se pudessem matá-los, pegariam suas canoas, seus barcos, e atravessariam o "grande rio" - o mar -, retornando para a África.

Naquela época, na busca de lideranças que pudessem ajudar em um grande movimento de revolução, foram escolhidos escravos com capacidade de liderança, mais de ordem política, tribal, do que religiosa. Para cumprir o objetivo, que era a volta de todos para a África, era preciso que as lideranças de cada senzala tivessem um compromisso com o movimento. De que forma? Com uma iniciação no culto aos orixás, aos deuses africanos.

Para serem iniciados tinham que passar por uma série de provações e fazer uma oferenda junto à natureza, que era senhora daquela energia, daquele culto. Por exemplo, Xangô é representado nas pedreiras, Oxum nas cachoeiras etc. O indivíduo, o negro, sabia como sair da senzala, o que ele não sabia é para onde ir. Ele estava num país diferente, não tinha caminho, entrar na mata era suicídio, porque os índios o matavam com certeza. Era essa dificuldade que ele enfrentava, não para sair da senzala, mas ir para onde? Não tinha para onde ir. Então o que acontecia?

Esse indivíduo era levado na calada da noite, tirado da senzala, levado até uma cachoeira, uma pedreira, um lugar onde ele faria a obrigação. Na obrigação fazia três coisas: uma oferenda no local, sofrer um rito, uma lavagem na cachoeira ou alguma coisa assim, e ele deveria guardar desse lugar um pedaço, um pedaço do solo sagrado onde ele fez isso. A escolha caía sempre sobre uma pequena pedra.

\section{Então o que significava essa pedra?}

Um pedaço do solo sagrado onde ele fez a oferenda. Para que não houvesse delatores eles faziam o seguinte: você vai ter que pegar alguma coisa do seu patrão para oferecer para o orixá. Como eram poucas as coisas que ele podia pegar do patrão, já que mesmo a vida do escravocrata era muito singela, então teria de ser algo importante, como as oferendas de vinho de palma, um vinho que é feito do fruto do dendezeiro. O que eles faziam? Roubavam uma garrafa do vinho da adega do senhor de escravos, porque todos eles tinham, poucos ou muitos, todos eles tinham alguns vinhos. O vinho fazia parte da alimentação natural, só que como o rei não permitia que se fabricasse vinho aqui, nós éramos sempre obrigados a comprar o vinho de Portugal e pagar o preço que eles quisessem. 
Muito bem, uma parte da oferenda era sempre feita com uma garrafa de vinho que havia sido subtraída. Feita a obrigação, se aquele escravo tentasse falar qualquer coisa para o proprietário, os demais escravos diziam:

"Não, ele está mentindo, está querendo nos culpar porque ele roubou uma garrafa de vinho, está em tal lugar". E com isso se comprava o silêncio, ou se obrigava o silêncio.

Era uma luta surda, mas inteligente. A essas lideranças era ensinado tudo o que eles achavam importante. Um grupo escravagista nunca pegava a mesma tribo. Eles podiam até prender uma tribo inteira, mas quando chegavam aqui, seus integrantes eram vendidos separadamente. Nunca pegavam parentes muito próximos, para evitar que houvesse união. Eles queriam que não se entendessem, então quando algum fazia alguma coisa ao outro, querendo agradar o patrão ou para fugir de um castigo, delatavam.

Esse era o objetivo.

A união era perigosa, mas muito cedo, as cabeças imaginaram: "nós temos que quebrar isso, nós temos que nos unir". Eles não falavam a mesma língua, eram opostos, completamente diferentes, um magro feito um "pau de virar tripa", alto, dois metros de altura, e a grande maiorias, os angolanos, baixos, atarracados, com uma lordose acentuada, com uma bunda enorme...

Então, todos esses fatores contribuíam para a desagregação. Os angolanos eram pessoas de boa índole, os outros eram verdadeiras feras, compreende? E sempre traziam alguns muçulmanos, porque o muçulmano tinha um ódio de morte daquele que não era muçulmano, isso que agente vê hoje, passados quinhentos anos.

Quase sempre esses negros muçulmanos tinham um padrão de inteligência muito superior. Inclusive, na maioria das vezes, eram os mais cultos dos escravizados. Eles conheciam a matemática, a grande maioria deles sabia escrever em árabe, que era o idioma deles. Com o muçulmano eles aprenderam muito sobre a cultura árabe e é um erro pensar que os árabes eram atrasados, muito pelo contrário.

O branco não admitia que o negro tivesse seus próprios deuses, então ele procurava, vamos imaginar, o altar de Ogum, o altar daquele que fez uma obrigação para Ogum, o que ele deu de obrigação para Ogum? Ogum é o orixá do ferro, hoje diríamos que é o orixá da tecnologia do ferro, que faz a ferramenta, 
como do ferro que faz a espada e a faca, tanto daquele que faz o bem quanto daquele que faz o material de guerra.

O desejo de liberdade é inerente em cada um de nós, e então o que aconteceu? Essa necessidade de buscar a liberdade obrigava o negro a tentar se unir. Isso veio através dos séculos, no período imperial.

Uma coisa curiosa: quando o imperador - com a corte portuguesa que era tão quadrada, tão certa - chegou ao Rio de Janeiro, ele foi obrigado pelo protocolo a ser recebido primeiro numa igreja que era considerada a igreja dos pretos no Rio de Janeiro. Isso a história menciona pouco. Se você tiver interesse posso te dar datas, só que eu tenho que pegar meus livros de referência.

A umbanda como culto de terreiro não existia até o início do século XX. Ela não tem nenhuma referência histórica, embora a palavra "umbanda" apareça em um ou outro canto. A umbanda como religião, como culto, não existia. Mas existia o hábito das benzedeiras, essa miscigenação.

Eu disse para você do altar e acabei não completando: o negro para esconder a sua crença esculpia; ele sempre foi muito hábil com as mãos. Esculpia os santos católicos em madeira e fazia um oco dentro da imagem, e dentro desse oco ele colocava a pedra, o altar que ele havia recolhido o pedacinho de solo sagrado. Ele escondia lá dentro e depois fechava com cera. Quando o branco perguntava por que ele fazia aquilo, ele dizia que a imagem oca não trincava. Era uma mentira; trinca do mesmo jeito.

Bem, desta forma ele começou a transportar o orixá do ferro, como eu disse há pouco, o orixá da guerra, e ele olhou para a imagem de São Jorge e viu um santo vestido de ferro dos pés à cabeça, até o cavalo era coberto de ferro, então ele colocava a imagem de Ogum dentro do santo.

Com relação aos demais orixás, como Oxossi, que era o selvagem, o homem da mata, aí mostram para ele a imagem de um santo, esse é São Sebastião, o que ele vê? Um homem seminu crivado de flechas. O altar de Oxóssi escondia-se na imagem de São Sebastião, e assim ele foi transportando os nomes dos orixás africanos "pros" santos católicos, principalmente aqueles mais cultuados aqui.

Mas o culto era sempre feito na natureza, e isso não mudou. Quando nós conhecemos o Parque do Pedroso, nem sabíamos que se chamava Parque do 
Pedroso, a gente vinha na pedreira, que ainda tinha uma detonação por dia, ao meio dia, de segunda a sexta. Sábados e domingos a pedreira ${ }^{12}$ não trabalhava.

Então, como tinha um pequeno córrego, e as pedras, que é a casa de Xangô, muita gente vinha para cá, para fazer as suas oferendas. Aqui tinha um senhor que tomava conta da pedreira, o porteiro, para quem trazíamos alguma coisa: um pouco de açúcar, um pouco de feijão, dava uns trocados para ele, que permitia que fizéssemos a oferenda.

\section{Isso em que ano?}

Isso já na década de 1960, até na década de 1950 mesmo. Eu me lembro que em 1955-1956 nós já frequentávamos aqui, mas não era com freqüência. A gente vinha a cada dois meses, a cada três meses, em setembro, na data de Xangô; em julho também tinha uma data destinada a Devido a essa miscigenação, os santos todos se sincretizaram da mesma forma no Brasil todo, mas na Bahia houve uma modificação. Como o santo de devoção do maior proprietário de terra lá era Santo Antônio, lá Ogum virou Santo Antônio. Aqui, no Rio de Janeiro e em São Paulo ele virou São Jorge.

Mas veja bem, volto a repetir, os fatos são bastante anteriores. Nós vínhamos para cá, hora a gente encontrava um grupo, hora a gente encontrava o outro, mas acontece que com o tempo começou a coincidir de agente encontrar as mesma pessoas, e eu era cheio de dúvidas, eu tinha muitas dúvidas, compreende? E como eu já tinha trabalhado, fazia radiojornalismo, na Rádio Cacique de São Caetano do Sul, que me aproximou um pouco mais de outras pessoas, o que eu propus quando vim aqui é o seguinte: como nós não sabíamos se a umbanda tinha um altar católico, uma prática espírita, e o ritual que é meio africano meio indígena, eu queria entender esse coquetel.

Alguns autores, como Matos Silva, falam que a umbanda tem suas origens na Lemúria, e que os egípcios já conheciam a umbanda. Eu não consegui imaginar o faraó incorporando o Caboclo nem o Preto Velho, "o pino era redondo a entrada era quadrada", não ia entrar nunca, compreende?

Questiono tudo isso, não só um passado branco, deixando o negro de lado, como dizer que a umbanda era mais antiga que o cristianismo? Desde o

\footnotetext{
${ }^{12}$ A antiga Pedreira Montanhão, de extração de brita, explorou por quase 50 anos o morro alto e íngreme, aproximadamente quatro vezes mais alto que os morros adjacentes. A brita extraída foi utilizada na construção civil e na construção da primeira pista da via Anchieta, segundo depoimento de
} 
princípio, com a própria presença do Preto Velho incorporado, era patente que a umbanda era verde e amarela, nasceu aqui, no nosso calendário, que é todo católico. As nossas datas são sempre as datas dos santos católicos. Como nós nos encontrávamos aqui, eu fiz uma proposta. Um dia estávamos em cincos grupinhos diferentes, e eu chamei o pessoal e disse:

"Vem cá, me permitem uma pergunta? Há quanto tempo você está na Umbanda?"

"Ah! Eu estou na Umbanda há dez anos."

"Qual é a tenda de umbanda mais antiga que você conhece?"

Minha conclusão é que não tínhamos nada. Dos anos 60 para trás a Umbanda tinha nascido mais ou menos há uns trinta anos, como cogumelo, um pouco no Rio, um pouco em São Paulo e um pouco no Rio Grande do Sul. Pouca gente sabe disso, mas hoje o maior núcleo umbandista do país fica no Rio Grande do Sul.

Então, eu sugeri ao pessoal que nós passássemos a nos reunir uma vez por mês, não para fazer trabalho de umbanda, sem falar de Caboclo nem de Preto Velho, mas da religião. Vamos ver o que você sabe e se conseguimos encontrar um fim. No fundo, meu sonho era o seguinte: se eu encontrasse quem fez o primeiro eu teria como explicar tudo, porque isso é dessa forma. Nunca imaginando que essa pessoa estivesse viva, se é que ela existia.

Desse encontro e dessa facilidade com que eu trabalhava no rádio, eu acabei liderando o grupo. Embora eu trabalhasse fora, a rádio nunca me sustentou, mas sempre me dava uns trocadinhos, dava para pagar a mensalidade da escola. Nós nos reuníamos na Rua Guapeí, em Santo André, na Rua São Paulo, aqui no terreiro da Dona Jandira, no terreiro da Dona Natália.

Nós nos reuníamos em vários pontos do $A B C$, éramos cinco, no total de umas quinze pessoas, depois foi crescendo e a pergunta era sempre a mesma: "qual a tenda mais antiga?"

Sr. Gilberto Bianchi, ex-proprietário da Elétrica Vitória, que fez as instalações da Pedreira Montanhão. (FUGABC, 2005). 


\section{Como essa prática religiosa é compatível com a unidade de conservação? Os ritos não podem ser praticados no parque. Como vocês resolvem o conflito?}

$\mathrm{Na}$ verdade não há um conflito, mas eu vou te responder... Veja a importância desse espaço para nós. Não tínhamos direito nenhum aqui, vínhamos e ocupávamos.

Nós tivemos uma conversa com o Corazza $^{13}$, que era engenheiro, e a Nívia, que era a secretária do Dr. Corazza, que era umbandista. Ela tinha uma irmã que era médium, então, ela abriu uma janela para nós junto ao Corazza. Fomos conversar e falamos:

"Olha Corazza, tem uma área!"

Nessa altura ele já estava sabendo que fazia parte do Parque do Pedroso.

"Nós precisamos usar lá, para fins religiosos",

"Mas vocês vão lá e vão acabar com tudo?",

"Não vamos acabar com nada. Se o senhor quiser vir conosco, vai constatar que não é esse o objetivo."

Então, com o aval verbal do Prefeito, nós começamos a fazer os nossos primeiros trabalhos. Eu nem me lembro o ano, mas foi na administração Corazza.

A pedreira acabou e não pagou ninguém, nenhum funcionário. As pessoas que trabalhavam aqui começaram a construir barracos e ficar por aqui, porque não tinham para onde ir. A casa do caseiro estava uma desgraça. Nós reformamos uma primeira vez, num trabalho de mutirão; o telhado já tinha caído... Então fomos criando as nossas raízes aqui.

Então, nessa época, o santuário, pelo que é do meu conhecimento, era o fundo do vale do Montanhão. Era um monte quatro vezes mais alto que qualquer um desses aqui. Ele era um monte como o Pão de Açúcar, bem íngreme, só que era vegetado. Tinha uma camada de terra e era vegetado.

Acontece que os italianos que colonizaram aqui, os chamados batateiros, foram os primeiros colonos que tiraram daqui a madeira de lei, que fizeram famosa a indústria de móveis de São Bernardo do Campo. Até a criação do GEIA ${ }^{14}$, no governo Juscelino, São Bernardo só era conhecido pelas fábricas de móveis. Não tinha nada aqui. A primeira montadora de automóveis que se estabeleceu foi a

\footnotetext{
${ }^{13}$ Conrado Bruno Corazza foi Superintendente do SEMASA e várias vezes Secretário de Obras da Prefeitura de Santo André.

${ }^{14}$ GEIA. Grupo Executivo da Indústria Automobilística, implantando várias indústrias de automóvel no país. In http://www.brasilescola.com/historiab/jucelinokubitschek.htm.
} 
Varian Motores, que pertenceu a um armênio, que também era dono do Hotel Danúbio, do balneário Danúbio, na Brigadeiro Luís Antônio. Um milionário armênio que trouxe a Varian Motores, que produziam os automóveis Nash.

O restante das indústrias não era daqui. A FORD era no Bom Retiro, a GM em São Caetano do Sul, e aqui não tinha indústria. Com a criação do GEIA e mesmo antes, quando fizeram a Via Anchieta, toda a brita para a obra da Via Anchieta saiu daqui.

Dessa montanha enorme tiraram a madeira de lei, e quando não tinha mais madeira de lei, os italianos começaram a tirar a madeira para vender como lenha. O que não servia como lenha era transformado em carvão para atender à indústria siderúrgica que começava a se formar. Abasteceram as padarias e, principalmente, as ferrovias, que eram movidas a lenha (as locomotivas a vapor). Isso aqui foi tudo destruído, acabaram com tudo.

Aqui, onde você pode ver que os montes são suaves, eles reflorestaram com eucalipto, que era uma espécie estrangeira, mas que se reproduzia muito depressa.

Por isso você ainda vê tantos remanescentes de eucalipto na região. Mas a Mata Atlântica foi embora.

O morro era muito íngreme, dava muito trabalho para plantar eucalipto, então abandonaram, e a erosão botou tudo abaixo. Quando a terra desceu, viram porque era um monte tão alto: era uma rocha imensa! Cinquenta anos de dinamites na rocha, só atividade destrutiva e extrativa, onde hoje é o vale era antes um buraco com mais ou menos 15 metros de profundidade, e como era um depósito grande, essa água se tornava fétida. As crianças queriam nadar aqui, mas muitas se afogavam.

Quando eu peguei, não tinha nada aqui. Não tinha verde há quarenta anos. Por outro lado, nós, os umbandistas, esperávamos sempre um lugar onde pudéssemos trabalhar sem que precisássemos correr da polícia. A mesma perseguição aconteceu aos primeiros cristãos, chamados de "uma louca superstição", era esse o nome que davam aos cristãos. Nós recebemos o mesmo epíteto.

Muito bem, a minha idéia com relação ao santuário foi diferente. Foi juntar as tendas que quisessem ajudar a recuperar esse lugar. No espaço para as tendas, se houvesse alguma planta, não poderia ser retirada, se não tivesse, era obrigado a 
plantar. Plantar ao longo da cerca e fazer um pequeno bosque, e ocupando a clareira do meio, e só trabalhando nesse lugar.

Então, com esse desejo de trabalhar nesse lugar, é que nós começamos os primeiros movimentos. Não saiu exatamente como a gente esperava, nem todos entenderam. Alguns quiseram se estabelecer aqui e nós não permitimos.

A promessa feita ao Corazza, de que nós recuperaríamos a área, estava feita.

Mais tarde tivemos algumas dificuldades aqui. Muitas pessoas foram reclamar com o Lincoln Grillo que estavam com dificuldade, porque ainda era o guarda da pedreira que tomava conta do lugar. Grillo chamou um assessor de imprensa dele para conversarmos que se chamava Luiz Gambeta Sarnento, que foi diretor da Gazeta do Grande ABC.

Queria fazer o santuário lá, num lugar onde nós pudéssemos fazer oferendas. Havia o espaço onde fica hoje a Avenida Lagos, ao lado da faculdade, onde se formou uma favela imensa, que naquela época era um bosque de eucaliptos, bem menor do que aqui, mas o Grillo não concordou.

Aquilo seria um grande parque para a cidade de Santo André, um Ibirapuera em Santo André, mas já estava sendo tomado por barracos e realmente se transformou em uma favela monstro, a maior.

Então não tínhamos outro espaço e viemos parar aqui. Nessa altura, um grupinho nasceu para estudar a umbanda, recebeu como primeiro nome "Núcleo de Estudos da Doutrina Umbandista", depois passou para "Curso Sobre Incorporação e Mediunidade de Desenvolvimento". Não sabíamos quem tinha feito tudo isso. A necessidade de ensinar para esse pessoal me fez encontrar um dia, por acaso, numa antiga revista de umbanda uma frase exclusiva: "eu fundei a umbanda". Eu não podia acreditar.

Um dia, eu fui ao Rio e fui verificar se o que a revista dizia era verdade ou não. Fui para um lugarejo chamado Cachoeiras do Macacu, procurando por uma pessoa de nome Zélio Fernandino de Morais, que tinha 80 anos.

A pessoa que eu encontrei sabia tudo sobre umbanda.

A organização cresceu e passou a chamar-se Federação Umbandista do Grande $A B C$, e hoje é o pólo umbandista mais importante do país.

Nascemos para ser uma Federação Mirim (Santo André, São Bernardo e São Caetano). A tenda mais antiga do Brasil, a tenda Nossa Senhora da Piedade, é nossa filiada e nós estamos em negociação para abrir uma tenda em Londres - já 
temos no Uruguai. O santuário acabou virando a "meca" dos umbandistas. Hoje existe um santuário em Poços de Caldas, um em Mato Grosso, um em Caxias do Sul, todos eles espelhados no trabalho que nós fizemos aqui, com todo apoio dos municípios, porque o hábito de se fazer oferenda, que vem da época dos escravos, aqueles pratos de barro com a oferenda, emporcalhava várias cidades aqui.

Criei um espaço onde a pessoa pode fazer isso, só que eles deixam a oferenda hoje, ela permanece de hoje para amanhã e é retirada e o espaço é limpo. Antigamente, se você viesse na Vila Luzita sexta-feira à noite e faltasse luz, o pessoal ia demorar pra perceber que tinha faltado luz, porque tinha muita vela acesa nessas ruas de terra. Eu resolvi esse problema.

Para nós, o santuário no Parque do Pedroso acabou encerrando a célula definitiva da umbanda.

Zélio de Morais, a pessoa que fundou a primeira tenda de umbanda, foi a pessoa que mais enalteceu o nosso trabalho. Os festejos dos cem anos da umbanda foram realizados aqui. Imagine o quanto isso foi importante.

$\mathrm{Na}$ gestão do Lincoln Grillo fizemos festas da umbanda a pedido do Prefeito. Festas com fins puramente eleitoreiros. A primeira foi um fracasso. A segunda nós fizemos por ocasião do aniversário da cidade, e a terceira foi quando lotamos o Parque Jaçatuba de umbandistas.

Eu queria que a situação do santuário fosse regularizada, já que era uma posse de fato, mas não de direito. Então, o que Grillo se dispôs foi a criar o nosso santuário, mas a princípio era a prefeitura quem iria administrar, o que inclusive é inconstitucional. Então, na mesma data que inaugurou o teleférico - foi num sábado -, no domingo nós inauguramos o santuário. No teleférico não havia mais do que mil e duzentas pessoas na inauguração, sendo que a metade eram crianças. Deveria ter uns 600 adultos.

Aquela foto é da inauguração, onde você vê que ainda faltavam muitas benfeitorias. A guarda municipal, com motociclistas, foi para cuidar do trânsito. Grillo teve de vir a pé de onde tinham as cavalarias. O Diário do Grande ABC, por amostragem de fotos, calculou uma média de quinze mil pessoas.

Isso foi nossa grande sorte e nosso pior pesadelo.

Grillo, logo no dia seguinte, me chamou dizendo que queria as trinta e duas federações de umbanda aqui. Comecei a perceber que o Lincoln estava começando a colocar nossa organização de lado e isso me revoltou bastante.

A área era nossa. Nós a fizemos! 
Ninguém, além de nós, veio aqui para fazer essa mata nascer. Passamos centenas de finais de semana indo aonde tinha mata, indo ao alto da serra, rastelando folhas, sementes. Nós estávamos trabalhando, tirando, às vezes, setenta, oitenta centímetros de pó de pedra para colocar terra e húmus, pagando a terra para vir de fora. Fizemos tudo isso e agora tudo iria para os outros?

Na cabeça do Grillo, se uma federação tinha colocado quinze mil pessoas, se ele tivesse o beneplácito das outras trinta e duas, a quinze mil por cada federação...

Quando Celso Daniel assumiu pela primeira vez a prefeitura, nós todos ficamos assustados. Todas as concessões ao longo da Avenida Capitão Mário de Toledo Camargo - uma associação para os dentistas e outra para a polícia militar foram retomadas. Ele tornou tudo sem efeito, então era uma questão de tempo até eles chegarem até nós, então eu juntei a minha diretoria e falei:

"Nós perdemos essa parada."

Quando o PT assumiu a prefeitura nós fomos hostilizados por um grupo.

Quem assumiu a administração do parque foi o Reinaldo Queirogue. Ficou como administrador do Parque do Pedroso, e o que eu não sabia era que a mãe do Ronaldo Queirogue, uma umbandista afiliada, e o próprio Ronaldo, tinham me ajudado várias vezes a fazer a festa de lemanjá na Praia Grande. Quando o Celso Daniel começou a cancelar tudo eu juntei toda a papelada e pedi uma audiência. Fui falar com o Queirogue e devolver para a prefeitura, certo? Só pedi para não mudarem a destinação do santuário. Isso acabaria com o Parque do Pedroso, porque voltaria com a "porcalhice" das oferendas por toda a cidade.

Nosso primeiro contato não foi nada amistoso.

Depois a prefeitura pediu para que o santuário ficasse. Muito tempo depois disso tudo acontecer, Celso Daniel veio aqui e ficou muito impressionado com o que ele viu, e voltou outras vezes, e quando estava em campanha ou não, ele vinha. Disse-me que era agnóstico, que não acreditava em nada:

"Eu posso não acreditar em nada, mas eu sinto uma paz tão grande quando eu venho aqui!" Ele morreu em janeiro, numa sexta-feira, antevéspera da festa de Oxóssi. No domingo estava tudo combinado: viria a Heleni de Paiva (vereadora) e um deputado, esse me foge o nome. Tinham curiosidade para conhecer a festa de Oxóssi, que é o orixá da mata, é dia 20 de janeiro.

Com o Avamileno nós tivemos o direito real de uso desse espaço, por vinte anos, e eu espero que seja renovável por muitos outros. 


\section{Como o senhor vê a apropriação de um espaço público para o uso privado do santuário?}

Quando a Federação Umbandista do Grande $A B C$ já reunia mais de trezentas tendas nós já éramos uma organização poderosa.

Utilizar um bem público era, antes de mais nada, ter um espaço onde nós pudéssemos praticar o nosso rito. Com isso você não encontra altar nos jardins públicos de Santo André, nas ruas ainda não asfaltadas de Santo André, porque existe um espaço para isso.

Parar o santuário hoje é uma tolice, porque o pessoal virá, vai invadir essas matas que não são policiadas. O único acesso fácil e direto que nós tínhamos para cá foi fechado, o do posto da guarda de destacamento ecológico. Eu, de boa vontade, colocaria naquele local, no limite do asfalto, uma portaria, com gente de minha responsabilidade, e me responsabilizaria por todo esse lado do parque, se a prefeitura assim o desejar. Para nós, o ruim é essa estrada que vem de São Bernardo do Campo.

A Federação Umbandista do Grande $A B C$ nunca pediu e não quer nenhuma subvenção da prefeitura. Nós não custamos um centavo para a Prefeitura de Santo André, não custamos um centavo para o Governo Estadual e nem para o Governo Federal. Tudo aqui é feito única e exclusivamente pela comunidade umbandista

- Federação Umbandista do Grande ABC -, hoje a maior instituição do gênero no país, com perto de duas mil e duzentas tendas registradas. Tornou-se a instituição líder no gênero, porque nós propiciamos esse espaço.

Não se cobrava entrada na portaria, a princípio. Os usuários cuidavam das áreas e nós cotizávamos para pagar tudo aqui. Então o dinheiro era sempre muito curto. Veja, eu recuperei toda a área de mata. Você vendo as fotografias, eu recuperei toda essa área de mata, e nós recuperamos uma boa parte da fauna. $\mathrm{O}$ pessoal que vem aqui é instruído no sentido de não fazer sujeira, nem oferenda, e isso é limpo todos os dias. Eu chego a colocar duas, três caçambas de lixo - oito a nove toneladas de lixo -, que daqui saem para o depósito. Se nós não estivéssemos aqui, a prefeitura teria que pegar esse lixo nas trilhas que tem aí por dentro.

Nós tivemos o trabalho de construir um minhocário, um viveiro de mudas; consultamos vários especialistas, uma bióloga, Dra. Joyce Egly, que ficou mais de 
um ano para que pudéssemos recuperar isso tudo: sessenta e cinco mil árvores plantadas.

Hoje já é raro encontrar uma oferenda na estrada, que é policiada duas vezes por dia, a não ser quando eu fico sem veículo. Para fazer isso hoje nós precisamos de uma caminhonete Toyota, um jipe Toyota, uma Blazer e uma caminhonete Nissan. Fazemos tudo isso sem utilizar um centavo da prefeitura. conjunto de sanitários recebe todo um tratamento biológico dos resíduos, e a cada sessenta, noventa dias nós retiramos toda a lama depositada.

No fundo do vale só temos sanitários químicos, que são limpos toda semana. O Sr. Cláudio vem e faz o tratamento. Contratamos uma pessoa de fora para fazer esse serviço. Tudo o que eu queria era por todas as imagens aí. Todas estão aí, menos a de Jesus. Até aqui Jesus está com dificuldades, não consigo colocar.

Tudo aqui era pelado. Nestes morros, a cada detonação de dinamite o pó ia se depositando nas folhas, as folhas secavam, as árvores morriam. Foi preciso refazer não só o fundo do vale, mas todo esse entorno aqui, onde víamos um ou outro eucalipto, mais nada.

Hoje estamos pedindo licença para retirar alguns eucaliptos, que oferecem o risco de cair. Não estou tirando todos. Cada um que a gente precisa retirar fazemos um ofício explicando o porquê, certo? Eu criei uma frase, que digo para você. Para essas coisas eu sou bom, já fiz muita publicidade, não é?

"O umbandista não precisa de uma catedral suntuosa como só o gênio humano é capaz de construir. Nós só precisamos de um pouquinho de natureza, como só Deus foi capaz de criar."

É isso que nós estamos fazendo, ajudando Deus a recuperar a natureza que tantos destruíram. Nós fazemos o contrário.

De helicóptero, o santuário é uma "minhoquinha desse tamanho", e o entorno dele que está aqui, porque nós estamos aqui.

Se você consultar 0 Febem ${ }^{15}$, você vai ver que foram inúmeras intervenções que nós fizemos. Quantas vezes eu fui pegar o Febem para indicar a favela que estava se formando. Trabalho de formiga. Pelam tudo, formam os barracos e aí vem a erosão. Aqui do lado de trás do santuário foram cinco vezes. Nós fomos recebidos até a tiros lá, para acabar com as favelas nesse trecho, nesse

\footnotetext{
${ }^{15}$ Aminadabe Belmiro Florêncio foi funcionário da Prefeitura Municipal, depois do SEMASA, atuando na área de fiscalização.
} 
entorno. Começamos a ver uma favela que ficava do lado de São Bernardo, que fatalmente desceria. Tinha um trailer desses bem estragados, de circo, ainda escrito "circo", sabe? Era o principal ponto de drogas daquela recém-criada favela. Como aquilo seria compatível com a unidade de conservação?

Veja bem, se para nós a natureza é tão importante, há toda compatibilidade.

Meu desejo, o meu sonho, era que deixassem o caminho que foi fechado aberto, com acesso só até aqui. Vou explicar todas as vantagens: seria muito mais fácil cuidar da fiscalização, nós não permitiríamos aqui o tráfego de pessoas que não viessem para cá. Isso está diretamente ligado ao município. Hoje, para chegar aqui, ou você dá essa volta por fora, ou pelo caminho muito mais prático, que é o de São Bernardo. Eu tenho $5 \%$, nem isso, de frequentadores que vêm aqui de Santo André. Quase a totalidade de munícipes de Santo André é obrigada a dar a volta por São Bernardo para vir para cá.

A cobrança de taxas está no decreto municipal, é autorizada e é para a manutenção da área de uso exclusivo dessa prática religiosa. Estando dentro de um parque, que é uma Unidade de Conservação de domínio público, como é possível a cobrança de taxa para acessar e conhecer o local?

Veja bem, quando o projeto foi feito o prefeito deixou. O projeto teve origem no executivo. Esse foi um compromisso que havia sido assumido ainda na época do Celso Daniel, e quando esse projeto foi apresentado não constava a cobrança de taxas, mas fica a pergunta:

Que eu saiba "só o criador fez do nada alguma coisa".

Eu precisava de recursos para isso. Do tempo que nós estamos aqui, começamos a cobrar a taxa de manutenção, há mais ou menos quatorze anos, nem isso, uns treze anos. Nunca tínhamos dinheiro para nada, a receita que tinha aqui era muito pequena, então juntamos os filiados, fizemos uma assembléia geral e eu até ameacei devolver tudo para a prefeitura, porque realmente nós não estávamos encontrando condições. Precisávamos de funcionários. Tenho vinte e oito funcionários hoje.

Enquanto nós estamos conversando, há dois homens de segurança aqui dentro. Esses homens me custam, no mínimo, cento e dez reais por dia. Como é que eu posso manter isso aqui? 
$\mathrm{Na}$ Câmara, os vereadores chegaram a conclusão de que não haveria a possibilidade de manter o santuário e concordaram com a proposta do executivo, acrescentado então a necessidade de cobrar uma taxa de manutenção, a mesma que nós cobrávamos antes. Não alteramos nada e com essa receita é que nós mantemos o santuário.

A lei e a constituição não permitem que o poder público patrocine qualquer religião. Então, eu não posso aceitar nada do poder publico. Não posso, não quero e não devo. Então a Câmara retomou a questão e foi aprovada tanto na primeira discussão quanto na segunda. Na primeira discussão nós fizemos a totalidade dos vereadores presentes, dezoito vereadores votaram favorável ao direito real de uso, e na segunda votação só dois não concordaram. Se não me engano, nós falamos com vinte vereadores, e dezoito foram favoráveis, dois não.

Ninguém dá quarenta anos da sua vida para nada, isso para mim é um sonho.

Isso não é uma herança minha. O dia que eu for embora eu não vou passar esse patrimônio para os meus filhos. Meu grande sonho é que isso aqui seja eterno. Enquanto houver um espiritualista, que ele tenha um lugar onde ele possa fazer sua oferenda sem ferir ninguém, sem melindrar ninguém. Quantos estiveram nesse meio tempo no Parque do Pedroso?

Vários.

A outra esquina ${ }^{16}$ foi cedida a uma instituição evangélica. Não quero falar mal de ninguém, mas quantas vezes eles fugiam de lá e vinham para cá? Eles pegavam essas crianças que ficam nos faróis e o que eles ensinavam para as crianças? Bíblia, bíblia, bíblia. Nunca se preocuparam em alfabetizar essas crianças.

A pedreira deixou um mundo de pó de pedra cujos sedimentos ainda estão aqui. A correnteza levou muito desse pó de pedra para aqueles lagos. Então, no começo do Desafio Jovem essas crianças eram vistas recolhendo pó de pedra do fundo do córrego, e eles fabricavam blocos de concreto. Você acha essa atividade ecológica?

Eles acabaram perdendo tudo. Na esquina tinha uma edificação, a antiga chácara "Tuti" [sic]. Eu me lembro que o teto era de madeira desenhada, uma tábua marfim, escura, muito bonita, era uma chácara de luz. Grillo chegou a pensar em fazer, a exemplo do que tem o palácio do governador, lá em Campos do Jordão, uma casa de campo do prefeito, mas "deram" para os evangélicos. Era uma

\footnotetext{
${ }^{16}$ Corresponde ao antigo Desafio Jovem, uma antiga chácara.
} 
maravilha de chácara, com todas as benfeitorias. Para mim, um buraco no meio das pedras.

Febem brigou tanto com esse pessoal, viu tanta irregularidade. Várias vezes as crianças fugiam de lá por fome e maus tratos e vinham parar aqui. O que eu fiz com essas crianças? Encaminhei ao juizado de menores. Elas morriam de medo do juizado, mas eu não podia ficar com essas crianças. É complicado pensar nisso, não é? Faz uns 22 ou 23 anos.

Acabaram com tudo. Febem me pediu e Aline ${ }^{17}$ acompanhou: fechei as janelas com tijolo, porque aquilo estava sendo usado para tudo. Abrigou seqüestrador, e traziam meninas da favela, drogavam-nas e deixavam-nas nessa casa abandonada. Nós vivíamos chamando a guarda municipal e a polícia de São Bernardo para intervir, principalmente de sábado para domingo.

Febem fez muito bem quando colocou tudo abaixo. Se você olhar esse trecho que a prefeitura recuperou, você vai ver que não tem nem $5 \%$ (cinco por cento) das árvores que vingaram. Eles têm trator e todos os recursos, mas não vai para frente. E eu aqui com pedras e recursos muito primários, sem máquinas e sem recurso nenhum. Não adianta, a terra é uma criança, ela exige cuidados; eu retiro pau podre e faço material biológico.

Algum tempo atrás, eles (a fiscalização) me surpreenderam fazendo algumas coisas erradas: fui construir a base (de uma imagem) como eu fiz de todas as outras imagens, e veio uma multa de $R \$ 12.000$, com a alegação de que eu estava desmatando.

O lugar lá é de pedra. Eu querendo recuperar a área, coloquei dois caminhões de terra. O caminhão de pedra não pensou duas vezes e despejou na pista. Sem que eu pudesse acompanhar, o trator fez o que queria, empurrou a terra para frente. Então, uma boa parte, dois caminhões de terra, cobriu uma parte do barranco. Alegaram que eu estava desmatando...

Eu entendo as suas perguntas. Entendo porque tem gente que acha que nós estamos fazendo uma fábula aqui. Quarenta anos da vida não são dois dias.

Eu entendo o seguinte: acho que Deus é muito mais do que esse Deus que fizeram. Acho que Deus fez o homem, fez o universo, que fez tudo isso. Cada um de nós tem um sentido e uma parcela desse Deus. Melhor que qualquer religião

\footnotetext{
${ }^{17}$ Aline Ferreira da Silva, Bióloga, trabalhou na fiscalização e hoje ocupa o cargo de Gerente do Controle Ambiental do SEMASA.
} 
é estar em paz com sua consciência. Não preciso ser católico, umbandista para eu levar minha vida. Se eu cumprir um só dos mandamentos, amar meu próximo como a mim mesmo, o resto é dispensável. Porque ninguém faria nada demais para mim.

Veja bem, não tenho ambições? Tenho. Quero minha casa, fui promovido a bisavô e foi de uma alegria imensa. Acho que estou tentando fazer o meu papel, o papel que me foi concedido nisso tudo. Tornei conhecida a história da umbanda, mas não fui o primeiro. 
Cristina De Marco Santiago 
Entrevistada: Cristina de Marco Santiago, Engenheira Florestal

Local: Centro de Referência em Saneamento Ambiental do SEMASA

Data: 04 de Setembro de 2009

Duração: $54 \min 11 \mathrm{~s}$

\section{Gostaria que você falasse sobre sua história com o Parque do Pedroso. Você conhecia o parque antes de trabalhar no SEMASA?}

Eu conhecia de nome, como todo andreense, pois sou nascida aqui. Aliás, meu avô já era nascido em Santo André. Nasceu em Paranapiacaba.

Quando a Subprefeitura (de Paranapiacaba e Parque Andreense) foi criada eu fiquei um ano e meio como diretora lá e depois voltei ao SEMASA, por volta de 2002, como assistente da diretoria do Departamento de Gestão Ambiental (gestão 2001-2004). À época havia um grande problema com o Parque do Pedroso: seu gerenciamento era feito pela prefeitura e, embora estivesse escrito na política de gestão ambiental que era competência do SEMASA, a gestão era totalmente equivocada em relação ao parque. Ele foi criado pela desapropriação de várias glebas na década de 1940. No Brasil, a criação de unidades de conservação passou a se disseminar na década de 70. Até então, tinha-se alguns parques, que foram os pioneiros do Brasil, mas não havia ainda uma motivação que pudesse influenciar os municípios.

Sempre foi assim. Parece que o município sempre vem depois, tomando iniciativas posteriores em relação à União e posteriores às iniciativas do Estado. $A$ criação do Parque do Pedroso foi uma iniciativa do município, que avalio ser absolutamente ousada para a ocasião, para a proteção dos mananciais. O objetivo não era unicamente de proteger, de conservar a natureza no âmbito que nós conhecemos hoje como unidade de conservação, mas, a exemplo de alguns outros parques, como o da Cantareira, era o de proteger os mananciais, A Cantareira era uma reserva para proteção dos mananciais, uma grande fazenda, e o Pedroso foi nesse mesmo sentido, o de proteger as nascentes para o abastecimento de água. Portanto, foi uma atitude visionária, por ter sido de iniciativa municipal. Por conta disso, sempre o achei uma pérola, inclusive pela história da conservação do Brasil.

Por outro lado, o parque tinha um manejo completamente equivocado. Então, uma das coisas que foi feita, na mesma época do processo de revisão da 
Lei Municipal ำ 7733/1998, por causa do licenciamento, foi aproveitar o momento e estabelecer as categorias de manejo de unidades de conservação municipais, definindo claramente seus objetivos, e enquadrar o Pedroso na categoria de proteção integral de parque municipal, embora já constasse anteriormente na lei como uma unidade de conservação.

A intenção foi de proteger melhor o parque e explicitar os objetivos de manejo. Os vasinhos retirados na limpeza dos cemitérios que eram jogados lá e o plantio de espécies de valor paisagístico no sub-bosque da floresta - para suprir a demanda dos plantios na cidade - eram ações que agrediam o objetivo de manejo do parque enquanto unidade de conservação.

Começou-se a fazer uma série de trabalhos no sentido de dar o manejo adequado. Sobre os Eucaliptus, foi sugerida a substituição onde era possível, onde a declividade permitia substituir e enriquecer com vegetação nativa. Foram diretrizes dadas que eu também não sei se foram encaminhadas posteriormente. $\mathrm{Na}$ época, o SEMASA se restringia à aplicação do programa de educação ambiental, um dos objetivos primários da categoria "parque". Quanto à fiscalização, determinamos uma diretriz, junto com o Eng. Luiz Fernando Bellettato, de fechar um dos acessos para resolver o problema do lixo que era depositado no local.

O parque é uma unidade que, por ser municipal, tem uma área efetiva muito grande - quase mil hectares. É uma unidade grande e são poucos os municípios que têm uma área como essa em função do objetivo inicial de proteção dos recursos hídricos, abrangendo uma bacia hidrográfica inteira, uma sub-bacia completa. Mas havia sérios problemas como, por exemplo, de manejo, de gestão adequada e também em relação ao entorno. Daí há toda uma leitura do SNUC ${ }^{1}$ sobre a zona de amortecimento que discuto no Instituto Florestal. O SNUC diz que o entorno das unidades de conservação são consideradas áreas rurais e, portanto, não poderão ser consideradas como áreas urbanas. Daí se faz uma leitura muito cômoda, por parte de alguns profissionais de uma certa linha de pensamento, que diz que não se pode em áreas urbanas delimitar as áreas de entorno das unidades de conservação como zonas "tampão", de amortecimento. Era outra briga que empreendíamos aqui também. Ou seja, pode sim! E deve!

No Pedroso, todo o entorno é absolutamente comprometido pela área urbana, e, pior ainda, envolvendo outros municípios, fugindo da governabilidade do município de Santo André. 
Já em São Bernardo do Campo tinha-se um problema sério: ele é um parque municipal que apresenta realmente problemas de gestão. A área de entorno não é de autonomia total do órgão gestor. Tem-se como intervir mais diretamente com uma capacidade de gerenciamento um pouco melhor, se está numa área territorial que é do Estado ou do Município. No caso de São Bernardo tem de haver um trabalho em parceira. Não sei se São Bernardo fez o plano diretor e como nele está contemplada a questão do parque, se houve a iniciativa de Santo André sobre o entorno do Pedroso, e se houve essa iniciativa de Santo André de parceria com São Bernardo. Isso é uma coisa interessante de se abordar, falando em paisagem.

O outro problema, que ocorreu já na minha saída, foi o da implantação do Rodoanel. Ele veio fechar com "chave de ouro" todos os problemas relativos à conservação propriamente dos recursos naturais do Pedroso.

\section{Gostaria que você falasse do Santuário Ecológico dentro do parque.}

Isso eu nem lembrava. É mais um dos graves problemas que há. Se não me engano, essa foi uma concessão dada em que, por fim, foi descoberto que tinha um documento oficial que dizia que o prazo dessa concessão já tinha expirado. Acho que era isso. O santuário tinha um discurso: "Estamos aqui para conservar."

Mas na verdade era outra agressão aos objetivos da categoria de manejo, não só do ponto de vista legal, mas do ponto de vista técnico também. Com a prática, acabamos sabendo discernir o que é um equívoco legal. Eu sempre trabalhei com políticas públicas no SEMASA e no Instituto Florestal, e sabe-se que muitas vezes a técnica, a ciência evolui e a legislação vai "a reboque" disso e muitas coisas acabam caducando mesmo (primeiro a realidade se modifica, depois a legislação). Mas não é o caso. Houve então uma autonomia muito grande na gestão daquela área específica do santuário do ponto de vista de recuperar as áreas, um plantio equivocado de espécies que não eram nativas. Houve uma total liberdade de intervenção, inclusive com construções que nunca haviam sido formalmente autorizadas. O correto ali seria realmente não impedir práticas religiosas (desde que estas não concorram com as funções das unidades de conservação, como ocorre no Pedroso, também podem ser desenvolvidas), mas impedir a ocupação de uma área tão significativa do parque, ocupada em tempo integral e com uma gestão tão dissociada da gestão maior do parque,

\footnotetext{
${ }^{1}$ SNUC - Sistema Nacional de Unidades de Conservação.
} 
independente. Isso realmente é um equívoco técnico e uma ação ilegal dentro da unidade, sem dúvida alguma.

Você participou do parecer, das discussões sobre o projeto do Rodoanel? Da forma como foi implantado, o Rodoanel compromete o parque?

Em 1987, se não me engano, fiz um curso de EIA-RIMA ${ }^{2}$ quando estava iniciando na FEEMA ${ }^{3}$ do Rio de Janeiro, e uma das coisas que logo se aprende é que a decisão é sempre política, e nunca técnica. E aqui teve-se uma dificuldade, inclusive de colocar as ideias no parecer do Rodoanel como acreditava-se que deveriam ser.

É óbvio que, para a conservação, o melhor seria que o traçado passasse no limite com a área urbana, e não onde ele passou. Isso seria o adequado.

Eu acho que até discutimos quais seriam, se não estou enganada, as implicações e as exigências técnicas que deveriam prevalecer caso o traçado fosse ao sul do Parque do Pedroso. Esse foi meu último trabalho. Eu já estava com meu prazo vencendo para assumir meu cargo no Instituto Florestal. Até estendi o prazo para concluir meu trabalho. E a primeira coisa com que trabalhei no Instituto também foi o parecer do Rodoanel, no trecho da Serra do Mar, em relação a outras unidades estaduais, e a mesma orientação técnica que foi dada aqui no SEMASA foi dada lá (no Instituto Florestal), ou seja, que fosse um padrão construtivo em superfície e não corte e aterro ${ }^{4}$. Alguns anos depois eu fiquei sabendo que não foi isso que aconteceu.

No parecer do SEMASA constam três opções: a primeira, cortando o meio do parque, que foi logo descartada. Depois a opção de um traçado ao norte que, por meio de ponte e túneis, seria a mais adequada. E a última, ao sul, além da implantação por corte e aterro, teria um sobrepercurso de quatro quilômetros, e mesmo assim a DERSA alegava que seria a opção mais viável e foi implantada.

\footnotetext{
${ }^{2}$ Estudo de Impacto Ambiental-Relatório de Impacto Ambiental.

${ }^{3}$ FEEMA - Fundação Estadual de Engenharia e Meio Ambiente do Estado do Rio de Janeiro -, por meio da Lei no 5.101, de 04 de outubro de 2007, foi unificada a outros dois órgãos ambientais vinculados à Secretaria de Estado do Ambiente (SEA) na criação do Instituto Estadual de Meio Ambiente (INEA): a Superintendência Estadual de Rios e Lagoas (SERLA) e o Instituto Estadual de Florestas (IEF).

${ }^{4}$ Em superfície, a rodovia seria construída por meio de pontes e túneis, não comprometendo o fluxo gênico. Realizada por corte e aterro, a obra provocou um desflorestamento maior, se mostrando mais impactante, isolando áreas, fragmentando ainda mais a mata.
} 
Ao sul passaria pela Pintassilgo, o que parece ter vindo a calhar para o município. Por quê? Não do ponto de vista técnico, da conservação, mas porque o município tinha a determinação do Ministério Público para desocupar a favela (Pintassilgo). Entretanto, o município não teve condições de fazer isso, não tinha verba para tal.

Outra discussão que sugeri e coloquei de maneira muito clara nos dois relatórios feitos foi a questão do plantio de árvores para o município que, no meu entendimento, não tinha valor nenhum enquanto compensação aos impactos sobre o parque. Nem lugar para plantar teria. Houve um cálculo que refiz do plantio de árvores, que estava muito aquém do que eles deveriam plantar em relação à quantidade de áreas a serem compensadas. E o mais adequado seria a aquisição daquela área, ao sul, cujo nome eu não me lembro. A sudeste talvez...

O Recreio da Borda do Campo tem uma área que é de reserva de área verde do loteamento, que não vou lembrar exatamente onde é, e teria que ter uma desocupação muito pequena de algumas casas. A integração dessa área seria um investimento por parte do município.

\section{Da Pintassilgo foram removidas 230 famílias. No Recreio o número foi bem menor: 23 famílias removidas.}

O Recreio tem uma reserva. O loteamento tem uma área de reserva com algumas ocupações pequenas, que na ocasião eram em número muito pequeno, e a proposta era incorporar essa área ao Pedroso. Eu não lembro se foi deixado um projeto disso.

A ideia era incorporar essa área ao Pedroso, desocupar a médio e a longo prazos algumas casas que ali ficaram, isso para ganharmos essa área. Creio que é uma das melhores áreas que temos no município como um todo até as três divisas, que tem uma vegetação que não encontramos no Pedroso, em lugar nenhum, até a represa.

Do ponto de vista da conservação, da qualidade da conservação, o Pedroso possui áreas muito fragmentadas. Isso significa o quê? Se for avaliar somente a paisagem, há recortes. Porém, do ponto de vista da conservação, existem vários estudos que já foram feitos e tem-se aquilo que se chama "efeito de borda". Neste caso, a insolação começa a comprometer muito a vegetação, a qualidade da vegetação, principalmente em áreas muito urbanizadas, com muitas 
intervenções. Tem-se a invasão de capins, a invasão de bambus, e começa a haver um grande comprometimento da biodiversidade.

O Pedroso tem essa característica. É necessário fazer um trabalho muito grande de recuperar e de enriquecer a vegetação, de fechar algumas estradas, de se criar bordas de vegetação no entorno para recuperar essa biodiversidade. Entretanto, tudo que se faça no Parque do Pedroso será pouco, se não mantiver um fluxo, uma possibilidade de fluxo gênico, que seria possível por meio desse canal que procuramos garantir, se observar uma imagem maior verá que essa é a única possibilidade de conexão com as demais áreas naturais do município, com as áreas de proteção dos mananciais.

Com toda essa somatória de situações tão específicas do Pedroso, os túneis para a travessia de fauna, enquanto solução para manter a conexão dessas áreas, representam um risco que tecnicamente jamais teríamos que correr. Poderia ser viável se tivessem outras conexões, mas sendo a única possibilidade, um corredor tão minúsculo, tão pequeno, para uma área com tantas pressões urbanas... No meu entendimento, jamais poderíamos ter corrido esse risco.

\section{O interessante é que isso é autorizado pelo IBAMA.}

Exatamente. Eu não sei por que esse trecho foi realizado em corte e aterro, porque também a orientação do Instituto Florestal foi que, não só essa região, mas toda a área de mananciais fosse feita sobre pontes e túneis.

\section{E ficando ainda mais ilhado, essas outras conexões com os municípios vizinhos não são suficientes?}

Tem-se na Represa Billings uma barreira concreta. A não ser a avifauna, os mamíferos não conseguem atravessá-la. Eu me lembro de ter afirmado isso de maneira categórica: apenas esse trecho, separado pelo Rodoanel, era a possibilidade de manutenção desse fluxo gênico. Eu não acompanhei mais essa discussão sobre a recuperação das $\mathrm{APPs}^{5}$ nos municípios, que seria outra possibilidade. Mas eu nem sei como estão hoje as APPs. Diferentemente do objetivo que ela foi criada em 1965, pela Resolução CONAMA 302 e 303, acrescenta-se a função de corredor de fluxo gênico. Mas é inviável, é um sonho mesmo em se falando da área urbana de Santo André.

\footnotetext{
${ }^{5}$ Áreas de Preservação Permanente.
} 
Complementando a questão, você falou que esse rompimento com o Rodoanel comprometeria a manutenção do parque como unidade de conservação. Gostaria que você explicasse isso.

O parque possui uma área fragmentada e muito pressionada, e ao perder a possibilidade de conexão de fluxo gênico, em médio prazo a tendência é ter um empobrecimento ainda maior da sua biodiversidade. Com o manejo seria possível recuperar. Mas essas possibilidades acabaram ficando muito pequenas.

Um colega seu, do Instituto Florestal, disse, em uma palestra na Semana de Meio Ambiente no SEMASA, que "gente e conservação não combinam". Eu gostaria de ouvi-la sobre isso.

Primeiro existem homens e homens, pessoas e pessoas. Eu trabalho com populações tradicionais, nativas. A conservação da natureza não se dá apenas por meio de unidades de conservação. Se observarmos, por exemplo, na "Estratégia Global para Biodiversidade" (início da década de 1990) e também na "Estratégia Mundial para a Conservação da Natureza" (de 1980), que tratam das políticas internacionais de conservação, há inúmeras outras formas de trabalhar a conservação. De acordo com a minha experiência de campo, tanto no Instituto Florestal, com reservas muito maiores que a área do município de Santo André, como com outras menores, como o Pedroso, não se consegue trabalhar a conservação colocando as unidades numa redoma. Não se consegue por quê? Acaba acontecendo que, a longo prazo, pensando em 100, 200, 300, 500 anos, que é a perspectiva de tempo que devemos ter para pensar as políticas de conservação, se não houver estratégias complementares às unidades de conservação nas áreas rurais, incentivando modos de vida vinculados à floresta e à agricultura familiar, a tendência é uma grande pressão sobre as primeiras, como, por exemplo, o que vivenciamos hoje para o Pedroso, pois o processo de urbanização é muito agressivo no Estado de São Paulo, assim como é contínua a expansão de empreendimentos de monocultura no campo.

Em Santo André perdemos os caipiras, que há muito tempo dominavam a área rural, cujo modo de vida harmoniza-se com o entorno de uma unidade de conservação. Agora, é óbvio que estamos falando de Santo André, que atualmente tem uma população urbana. E aí eu também sou categórica: simplesmente não combina. 
Acho que uma coisa é a população rural, onde se tem inclusive categorias de unidades de conservação que contemplam a presença de populações tradicionais: caiçaras, caipiras, ribeirinhos. Mas não é o caso aqui, em que se tem uma população urbana mesmo, que vive de forma urbana, que tem hábitos urbanos e tem um padrão de consumo típico da sociedade urbana, com um padrão de ocupação que é urbano. Então, em se tratando do Pedroso, mesmo sendo da vertente que não concorda que "homem e conservação não combinam", nesse caso específico, não tem como.

Você já falou sobre as espécies exóticas, mas gostaria que falasse um pouco mais sobre essa questão. Legalmente não é possível, não é recomendável para uma unidade de conservação. Tecnicamente, é um comprometimento muito grande para a floresta a inserção de algumas espécies exóticas?

Há algumas espécies que são exóticas e outras que não necessariamente são exóticas, mas têm um potencial invasor muito grande. Um exemplo disso é na Serra do Mar, onde no topo há uma trepadeira, um cipó que vai cobrindo como um lençol e é uma espécie nativa, não é uma espécie exótica, mas cobre como um lençol e vai matando a vegetação que está embaixo.

Então é claro que a gente tem que diferenciar o que é espécie exótica ou nativa que tenha um potencial invasor, evitando trabalhar o paisagismo da unidade com uma espécie que seja um problema. Há outras espécies que se adaptam muito bem e que são asselvajadas nos ecossistemas brasileiros. Sendo assim, de qualquer maneira, eu torno a reforçar que o que poderia ser menos comprometedor do ponto de vista da manutenção de espécies exóticas numa unidade de 300 mil hectares na Serra do Mar, com 26 mil hectares, com 30 mil hectares, 50 mil hectares, que é o padrão, com uma grande proporção de vegetação nativa, não se compara a uma unidade de conservação com mil hectares e com pressões urbanas tão grandes, como no caso do Pedroso. Por lei não pode.

Com a promulgação do SNUC a tendência foi só olhar para ele, mas existe um decreto, o Regulamento dos Parques Estaduais Paulistas ${ }^{6}$, que estabelece as mesmas orientações previstas no decreto que regulamenta os parques nacionais. É uma mesma regra para todos os parques, seja municipal, estadual ou federal. Ali está muito clara a questão das espécies exóticas, animais ou vegetais. Com

${ }^{6}$ Decreto Estadual no 25.341/86 aprova o regulamento de Parques Estaduais Paulistas. 
animais, é claro que há um comprometimento muito grande em relação aos cães e gatos, com esses tipos de animais que causam um impacto muito grande à fauna. E particularmente no Pedroso, eu diria que é muito comprometedor, porque a única possibilidade que se tem de fluxo é em relação à avifauna.

Então, podemos até fazer o manejo e garantir uma biodiversidade mínima trabalhando espécies vegetais que sejam mutualistas-chave ${ }^{7}$, ou seja, de importância para um grande número de espécies da fauna e da avifauna especificamente que possam visitar o parque. Seria a única saída que se teria de recuperação, mas teríamos que trabalhar com espécies que sejam obrigatoriamente nativas. Preferencialmente palmito, que na Mata Atlântica é um mutualista-chave. Há outras espécies com essa característica, mas o palmito é muito importante, pois existe um número grande de espécies da fauna que se alimenta dele. Então, pode-se atrair a fauna por meio de frutíferas, em especial as nativas, que são extremamente importantes. Temos que tomar cuidado porque a Mata Atlântica ocorre numa extensão muito grande e tem espécies que não são nativas do Estado de São Paulo - por exemplo, o pau-ferro ${ }^{8}$. Temos que tomar esse cuidado de trabalhar com espécies que sejam nativas e regionais. Os levantamentos feitos, principalmente nas áreas de mananciais de Santo André, são uma referência importante. Um trabalho do Hermógenes de Freitas Leitão Filho foi feito para o Guaraciaba, que é próximo ao Pedroso.

Hermógenes, já falecido, foi uma das grandes referências, uma das grandes autoridades em florística. Se olhar o RADAMBRASIL ${ }^{9}$, vai ver que não é à toa que Santo André, antigamente, chamava-se "Borda do Campo", Santo André da Borda do Campo. Temos manchas de campo. O Guaraciaba talvez tenha a vegetação mais próxima do Pedroso originalmente. Porém, são duas áreas muito impactadas. Pegando os levantamentos do entorno, acho que são boas referências. E procurar principalmente trabalhar com a atração da fauna, que vai ser a possibilidade de se manter minimamente a biodiversidade.

\footnotetext{
7 "As espécies envolvidas numa relação de mutualismo (interações mutuamente benéficas, como o caso da polinização de plantas por insetos) são profundamente afetadas se uma das espécies parceiras se perder". Disponível em http://www.naturlink.sapo.pt/article.aspx?prenuid=66\&cid=3221\&bl=1\&section $=3$

${ }^{8}$ Pau-ferro: Ceasealpinia férrea.

${ }^{9}$ RADAMBRASIL - Projeto RADAMBRASIL-1970 - , programa de implementação de pesquisas no campo de aplicação do sensoriamento remoto por satélite. Disponível em http://www.projeto.radam.nom.br/metodologia.html
} 
Há alguns trabalhos sobre fauna que falam sobre a ausência de avifauna de interior de mata, pelo estágio secundário que apresenta. Esse estágio é da região?

Estado de São Paulo inteiro! São raríssimas exceções.

Isso é consequência da ação humana, do contato urbano?

Uma coisa é a vegetação secundária onde, em todo o Estado de São Paulo, tínhamos uma população indígena grande que fazia uso dessa floresta. A floresta regenera-se, mas tem-se um problema muito grande de contato urbano. Aí está a dificuldade. Por isso a necessidade de manejar o Pedroso. Retirar as espécies exóticas, com certeza, e diminuir ao máximo o trânsito, os acessos. Aí acho que o Rodoanel é uma oportunidade. E, "doa a quem doer", deixar só o trânsito que realmente é necessário para não ilhar a comunidade - aonde houver outra alternativa -, mesmo que tenha que andar 20 quilômetros a mais. Infelizmente é isso! Então, é realmente fazer o que é absolutamente necessário: diminuir os acessos, recuperar a vegetação, e enriquecer onde é necessário. E o enriquecimento é feito com espécies que são de floresta madura e de ocorrência natural na área. É importante se priorizar espécies com potencial para a recuperação da fauna e avifauna.

Ouvi de uma equipe que trabalha as questões de meio ambiente do Rodoanel que os parques que têm uso (lazer) são mais conservados dos que os sem uso.

Isso é muito relativo. Acho que é uma postura muito cômoda. A prioridade é a conservação, é a biodiversidade, e obviamente depende muito do público que se está atendendo. Por exemplo, entendo que o público local que frequenta seja um público que se identifica muito mais com aquela unidade e ele tenha condição de protegê-la; em princípio um público educado. Por outro lado, pode ter mais facilidade de acesso, ter mais liberdade, ter mais conhecimento sobre a área e estar também com mais condições de fazer coisas erradas, digamos. Um público de baixa renda, não somente este, mas pessoas que passam fome vão ao mato e caçam. No caso do Pedroso tem que ter um uso, até porque é um dos objetivos de manejo da categoria parque, mas tem que ter um trabalho de educação ambiental 
que não é só a "cartilhazinha", mas o programa de jovens ${ }^{10}$, por exemplo, que não sei se ainda está lá. Em minha opinião, esse é o trabalho que realmente vale e fica.

A educação é um processo contínuo, é diferente de informar. É o que precisa com essa ocupação dentro do parque, no entorno dele: é educação! Não apenas informação. Embora seja também indissociável.

10 Programa de Jovens - PJ - Programa Reserva da Biosfera, ligado à Unesco e promovido pelo Instituto Florestal, em parceria com municípios. O Programa de Jovens iniciou-se em 2002 e agregava jovens de 14 a 20 anos que viviam no seu entorno do Parque do Pedroso. Era administrado pelo DGA do SEMASA. (Diário, 2005; GEMA, 2010) 


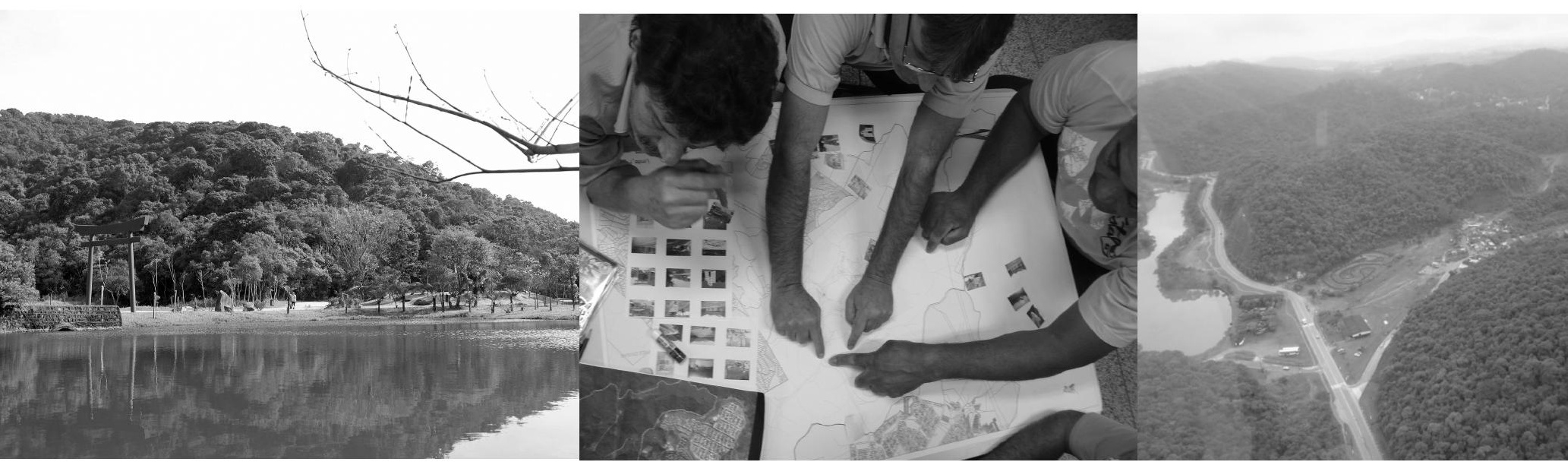

Anexo II

Modelo de Carta de Cessão 


\section{CARTA DE CESSÃO (modelo)}

Eu.

CPF

RG. .declaro,

para os devidos fins, que cedo à Biblioteca da Faculdade de Arquitetura e Urbanismo da Universidade de São Paulo os direitos de uso de meu depoimento

e sua

transcrição, intitulado.

Conforme cópia, aprovada integralmente em meu poder.Declaro também, que autorizo à Biblioteca da Faculdade de Arquitetura e Urbanismo da Universidade de São Paulo, sua publicação, no todo ou em partes, sem restrição de prazos ou citações.

Subscrevo-me a presente, na qual cedo meus direitos e os de meus descendentes.

São Paulo, .....de de.

Nome completo:

Endereço completo:

CEP.:

Telefone: 